\title{
EVALUATION OF JUVENILE FISH BYPASS AND ADULT FISH PASSAGE FACILITIES AT WATER DIVERSIONS IN THE UMATILLA RIVER
}

\author{
Annual and Interim Progress Reports \\ October 1990 - September 1991 \\ Edited By \\ Suzanne M. Knapp \\ Oregon Department of Fish and Wildlife \\ Cooperator 6 \\ Oregon Department of Fish and Wildlife \\ Confederated Tribes of the Umatilla Indian Reservation \\ Prepared For \\ Jerry Bauer, Project Manager \\ U.S. Department of Energy \\ Bonneville Power Administration \\ Division of Fish and Wildlife \\ P.O. Box 3621 \\ Portland, OR 97208-3621 \\ Project No. 89-024-01 \\ Contract No. DE-BI79-89BP01385
}

June 1992 
EXECUTI VE SUMMARY by Suzanne $M$ Knapp.................... 1

REPORT A Sampling pl an devel opment and preparati on for the eval uat $i$ on of the $j$ uveni l e fi sh bypass system $i \mathrm{n}$ the West Extensi on I rri gati on Di stri ct Canal at Three Mle Fal I s Dam and trap desi gns for fut ure eval uati ons at Maxuel I and Westl and dans by Suzanne M Knapp............6

REPORT B. Eval uati on of the $\mathrm{j}$ uveni l e fi sh bypass faci l ity in the West Extensi on I rrigati on Di stri ct Canal at Three M I e Fal I s Dam and document at i on of $j$ uveni I e sal moni $d$ passage through the bypass facility and east-bank adul t fi sh I adder by $M$ chael C. Hayes, Suzanne M Knapp and Anthony

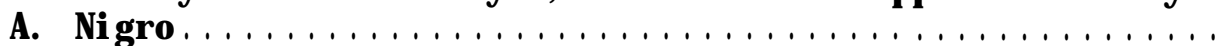

REPORT C. Exami ne the passage of adul $t$ sal noni ds at Three MIe Fal Is Dam by Paul 


\section{EXECUTI VE SUMMARY}

We report on our progress from October 1990 through Sept enber 1991 on eval uati ng $\mathrm{j}$ uveni I e fi sh bypass faci I iti es at Three M I e Fal I s, Mexuel I, and Westl and dans on the Unatilla Ri ver. We al so report on our progress from October 1990 through J une 1991 on eval uat ing adul $t$ fi sh passage facilities at Three MIe Fal Is Dam The study is a cooperative effort by the Oregon Department of Fi sh and $\mathrm{V}^{*} \mathrm{I} \mathrm{dl}$ ife ( ODFW and the Conf ederated Tri bes of the Unati I I a I ndi an Reservati on (CTU R). We report progress toward study obj ecti ves in three separate reports. Reports $A$ and $C$ compri se annual reports submitted to the Bonnevi I le Power Admi ni strati on (BPA) i n October 1991. Report B is an i nt eri m report submitted to BPA in J une 1992.

1. Report A (ODFW: Devel op a sampl ing pl an and prepare for the eval uat $i$ on of the $j$ uveni I e f $i$ sh bypass system i $n$ the Whst Extensi on I rrigati on Di stri ct Canal at Three MIe Fal Is Dam and desi gn traps f or f ut ure eval uati ons at Mexuel I and Westl and dans.

2. Report B ( ODFW: Eval uati on of the $\mathrm{j}$ uveni l e fi sh bypass faci I ity in the West Extensi on I rri gati on Di stri ct Canal at Three MIe Fal Is Dam and document at $i$ on of passage of $j$ uveni I e sal noni ds through the bypass faci I ity and east-bank adul $t$ fi sh I adder.

3. Report C (CTU R): Exami ne the passage of adul $t$ sal moni ds at Three Mi e Fal Is Dam

The study is part of a program to rehabi I i tate anadronous fi sh stocks in the Unati I I a Ri ver Basi $n$ that i ncl udes rest orati ons of coho sal non Oncorhynchus ki sutch and chi nook sal non 0 . t shawyt scha and enhancement of summer steel head 0 . myki ss.

\section{Report A}

Highl i ghts of resul ts of our work in preparing for the $\mathrm{j}$ uvenile fi sh bypass facility eval uati on in the West Extensi on I rrigation Di stri ct Canal at Three M I e Fal I s Dam and $f$ ut ure eval uati ons at Maxuel I and West I and dans are

1. A fi el d sampl i ng pl an was devel oped that i ncl uded detai l ed experi mental desi gns for fi ve tests: drum screen i nj ury, drum screen I eakage, bypass pi pe and outfal I i nj ury, headgate i nj ury and travel i ng screen I eakage. Procedures for rel ease, recapt ure, exami nati on, dat a col l ecti on and data anal ysi s for screen effici ency and i nj ury esti mates nere al so i ncl uded.

2. We sel ected fal I chi nook fry for the screen l eakage test si nce these fi sh woul d be potential ly vul nerable to ent rai nnent and screen i mpi ngenent shoul d nat ural producti on i ncrease i $n$ the I ower ri ver i $n$ the fut ure. Yearling sumer steel head and spring chi nook sal non and subyearling fal I chi nook sal mon were sel ected for the i nj ury tests. 
3. A system was devi sed to transport fal I chi nook fry usi ng 32- gal I on contai ners aerated with bottled oxygen. We pl anned to use ODFW 5 370gal I on haul ing tanker to transport the I arger fish.

4. We devel oped an on-si te hol di ng system that al I owed us to recei ve test fi sh i $n$ bul $k$ and I ater separate into 100-fi sh brand groups i $n$ smaller contai ners. We used pumped water from the canal to create an effecti ve water ci rculation system through I arge tanks whi ch contai ned the smal ler fi sh-hol di ng contai ners. Pl asti c hol di ng contai ners were perf orated and nesh-covered. Snal I ( 18 cubi c ft) and I arge (4-ft sq. $x$ 2-ft deep) net pens were fabri cated for use in hol di ng fi sh in the canal or ri ver.

5. Addi ti onal acti vi ti es i ncl uded fabri cation of a brandi ng table with si de trough for transferring fi sh to a hol di ng contai ner, and a separator slide gate to prevent fi sh fromentering the transfer fl une duri ng sample tank crouding. We i nstal l ed addi ti onal I i ghti ng for ni ghtti me acti vi ti es and hand wi nches to depl oy the bypass outfal I net pen. A trailer was procured to serve as an on-site field office.

6. For the drum screen I eakage test, we desi gned four fyke nets wi th frames to fit in the stopl og gui des behi nd each drum screen and conf or $m$ to the available space and water fl ow Fyke nets were 20-ft to 25-ft I ong and tapered to a I-ft square, 1.5-ft deep cod end. The cod end contai ned a zi pper to access the contents.

7. For the travel ing screen l eakage test, we desi gned and fabri cated a 14- $\mathrm{ft}$ I ong fyke net and a $2.3 \mathrm{ft} \times 2.8 \mathrm{ft}$ net frane for the river return drai $n$ pi pe. Frane gui des were affixed to the retai ni ng wall at the pi pe terminus to permit depl oyment of the net and frane.

8. An al umi num i ncl i ned pl ane trap was desi gned and fabri cated for use in collecting fish in the bypass channel at the Mexuel I Damfacility. The trap was desi gned to el i mi nate a l o-cubi c feet per second (cf s) bypass fl ow collect fi sh in a terminal I i ve box, and had a pi vot-rod front entrance assenbly to permi l everage capabi lities in adj usting water fl ow to the Ii ve box.

9. A $12.3 \mathrm{ft}$ I ong fyke net with terminal fl oating li ve box ( $1.5 \mathrm{ft} \times 3$ ft $\times 2 \mathrm{ft}$ ) was desi gned and fabricated for collecting fish in the j uveni I e fi sh hol di ng pond at West I and Dam

10. The wast ewater channel at the Maxuel I Damfacility was usually occl uded with debris at the entrance. We hypothesi ze that juveni l e fi sh may become stranded in the channel during peri ods of overfl ow abat ement due to a rel ativel y l ow return gradi ent to the river.

Report B

Hi ghl i ghts of resul ts of our work in eval uating the $\mathrm{j}$ uveni le fi sh bypass facility in the West Extension I rrigation District Canal at Three 
MI e Fal I s Dam and documenting $\mathrm{j}$ uveni I e fi sh passage through the bypass faci I ity and east-bank adul t fi sh I adder are

1. J uveni I e sal noni ds were not i nj ured as they noved past the drum screens and i nto the bypass channel during day and ni ght tests.

J uveni I e sal mon were al so not i nj ured through the bypass pi pe and outfal $I$ as they returned to the river at fl ous of 5 cfs and 25 cfs.

2. Li mited testing showed that j uveni I e sal mon were not i nj ured as they travel ed past the headgates into the screening facility during day and ni ght tests.

3. The drum screens were $99.8 \%$ effi ci ent in screeni ng fal I chi nook sal mon fry from the canal, with onl y 6 of the $900 \mathrm{fi}$ sh rel eased escaping through the screens. Lengths of these fish ranged from $60 \mathrm{~mm}$ to $66 \mathrm{~mm}$ near the average l ength of $f$ al I chi nook used i $n$ the tests. Mean effici ency rates for each of the four drum screens ranged from $99.6 \%$ to 99. 9\% We observed one i mpi nged f ry on a drum screen.

4. We capt ured one fal I chi nook subyearling ( $85 \mathrm{~mm} \mathrm{I} \mathrm{ong)} \mathrm{in} \mathrm{a} \mathrm{fyke} \mathrm{net}$ at the end of the ri ver return drai $n$ pi pe, si gni fyi ng possi bl e l eakage past the secondary traveling screen.

5. We observed $108 \mathrm{fal}$ I chi nook sal mon fry from the drum screen I eakage test that became i mpi nged on the secondary travel ing screen.

I mpi ngement was nore prevel ant when the ri ver ret urn drai $n$ pi pe was ful I y open than when the pumpback pumps were operating. Occasi onal i mpi ngenent of fal I chi nook sal non subyearli ngs was al so observed duri ng pumpback pump operati on; much i mpi ngenent of subyearl i ngs occurred when the drai $n$ pi pe was fully open to sl ui ce si It from the pump enbayment area. $\quad \mathrm{Nb}$ i mpi ngement was observed during a $\mathrm{ful}$ I bypass node of 25 cf s.

6. Approxi matel y 3 hours were requi red to capt ure $50 \%$ of the spring chi nook sal mon travel ing through the upper screening facility during day and ni ght tests. Fal I chi nook sal mon travel ed more qui ckl y at ni ght than during the day; fifty percent of the test fish were caught in one hour duri ng ni ghtti me tests compared to 5.5 hours for dayti me tests. Sumer steel head travel ed sl owest, requi ri ng 10.5 hours to capt ure $50 \%$ of the dayti ne test fish.

7. Mbvenent of fish through the I ower bypass at a 5-cfs fl ow was consi derabl y sl ower for al I speci es than at a 25- cf $s$ fl ow or than through the upper screening facility. After one hour of sampling at a 5 - cf s bypass fl ow we recapt ured $25 \% \quad 27 \%$ and $2 \%$ of the spring chi nook, fal I chi nook, and summer steel head, respecti vel y; at a 25-cf s bypass fl ow we recapt ured $32 \%$ of the spring chi nook, $62 \%$ of the fal I chi nook, and $16 \%$ of the summer st eel head.

8. Di el passage of hatchery-rel eased and wi I d j uveni l e sal mon through the bypass facility was greatest from sunrise through sunset. The hi ghest hourl y number of juveni l e sal noni ds count ed was about 1,800 on 24 Apri I and 2,000 on 8 My 1991. We counted a total of 41, $318 \mathrm{j}$ uveni le sal moni ds through the bypass facility from 5 April to 10 April and from 23 April to 9 May 1992. 
9. We counted approxi matel y 30,000 j uveni l e sal moni ds noving past the east-bank fi sh I adder vi ewi ng wi ndow from I ate March through earl y J une in 1990. These counts tended to peak 10 to 13 days after Unatilla Ri ver fl ous reached thei $r$ hi ghest poi nt.

\section{Report C}

H ghl ights of results of our work with the adult passage facility at Three Mle Fal Is Dam are

1. We counted 922 coho ( 410 adul ts and 512 j acks), 1,110 summer st eel head, 1, $061 \mathrm{fal}$ l chi nook (333, adul ts, 107 j acks and 621 subj acks), and 1, 330 spring chi nook (1,291 adults and 39 jacks) at the Three MIe Fal I s Dam east-bank trappi ng faci I ity in Fal I 1990 and Spri ng 1991.

2. M grati on peri ods of $f$ al I chi nook and coho extended from earl $y$ October through early Decenber and mid-February, respecti vel y. Summer steel head migrated from mid-October through early June. Spring chi nook migrated from early April through June. Ret urn timing was si milar for fal I and spring chi nook and coho sal mon but earlier for summer steel head compared to the previ ous year's returns.

3. The maj ority of the fal I chi nook and coho sal mon migrated to Three M I e Fal I s Dam when fl ous were bet ween 150 to $250 \mathrm{cf}$ s; the fl ow trigger for peak numbers passing the dam in I ate October and early November was 150 cfs. We hypothesi ze that I ow fl ows ( 25 to 250 cfs) during fal I nay be the naj or cause for straying problens observed for fall chi nook sal non. Mbst sumer st eel head arrived at the dam bet ween February and mid-Apri I; I arge numbers uere count ed as fl ows approached and exceeded 500 cfs. The maj ority of spring chi nook ret urned to Three MIe Fal Is Damfrom I ate Apri I through I ate Myy; peak novenent occurred as uater I evel s decli ned af ter hi gh fl ow events (>l,000 cf s).

4. Vi deo-tape sampl ing occurred from Oct ober through mid-Nbvenber 1990 usi ng vi deo-recordi ng equi pment i nstal I ed in the east-bank adul t passage faci lity vi ewing room of Three MI e Fal I s Dam Based on taped i mages, we counted 236 coho sal non, 925 fal I chi nook, 83 summer st eel head and 1,660 uni dentifiable fish. The hourly novenent of $f$ al I chi nook sal non vari ed greatl y from day to day.

5. Vari at i on i $\mathbf{n}$ compari son of adul $\mathbf{t}$ sal noni $d$ numbers by vi deo- tape i mages and di rect observations in the trapping facility exceeded $100 \%$. Speci es $i$ dent $i$ fi cat $i$ on and enumerati on from vi deo- $t$ aped $i$ mages of $f$ al $I$ chi nook and coho sal mon were difficult to make due to much back and forth novement and advanced speci es mat uration. We hypothesize that fal I back may be caused by i nadequate attracti on fl ous at the steep pass entrance i $n$ conj uncti on with attracti on fl ow interference from the $I$ ead gate.

6. A three-day operati on of the west-bank adul $t$ I adder and trap reveal ed structural and operational difficulties that my cause fi sh i nj uries and escape and precl ude effici ent and ef fecti ve trapping. 
7. Carcass surveys conducted dounst ream from Three M I e Fal I s Dam i n the fal I of 1990 counted 120 dead fal I chi nook, 5 dead coho, and 14 occupi ed and 39 unoccupi ed redds. A mi mim of $24.8 \%$ of the $f$ al $I$ chi nook ret urn to Three MIe Fal Is Dam spawned bel ow the dam We hypot hesi ze that I ower ri ver spawni ng may have been due to I ower ri ver j uveni l e fi sh rel eases in 1986 and the exi stence of a structural barrier to I arge fish at the fish I adder.

8. We observed 194 spring chi nook in prespauning surveys conducted in the upper Unati I I a Ri ver and tri but ari es i $\mathrm{n}$ I ate J une through mid-J ul y; four nortalities and two emi nent mortal iti es were noted. An addi ti onal 73 spring chi nook were observed in the Tribal harvest. 


\title{
REPORT A
}

1. Sampl i ng pl an devel opnent and preparati ons for the eval uati on of the $\mathrm{j}$ uveni I e fi sh bypass system in the West Extensi on I rrigation Di st ri ct Canal at Three M le Fal Is Dam

2. Trap desi gns for fut ure eval uati ons at Mexuel I and West I and dans.

\author{
Prepared By: \\ Suzanne M Knapp \\ Oregon Department of Fi sh and $\mathrm{V}^{*} \mathrm{I}$ dl i fe \\ 2501 S. W Fi rst Avenue \\ P. 0 . Box 59 \\ Portl and, Oregon 97207
}




\section{CONIENTS}

Page

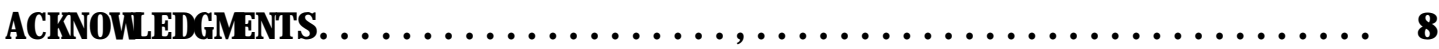

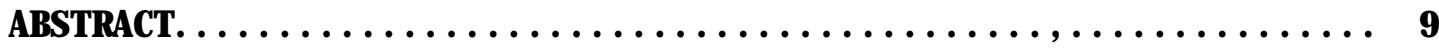

I NTRODUCTI ON . . . . . . . . . . . . . . . . . . . . . . . . . . . . . . 10

Background . . . . . . . . . . . . . . . . . . . . . . . . . . . . . . . . 10

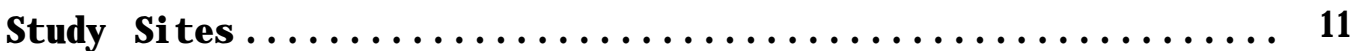

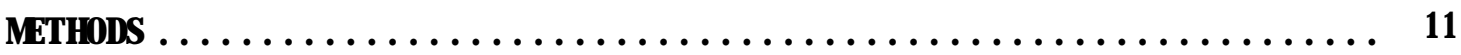

Three MIe Fal Is DamJuveni I e Bypass Facility

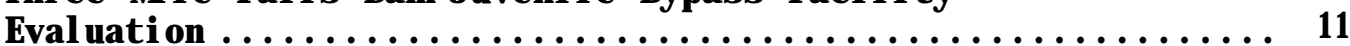

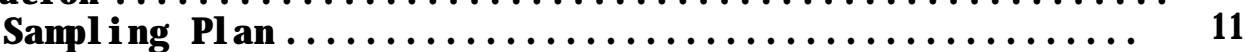

Preparatory Activities .......................... 18

Upri ver Acti vi ti es at Maxuel I and Westl and

Di versi on Dans..................................... 20

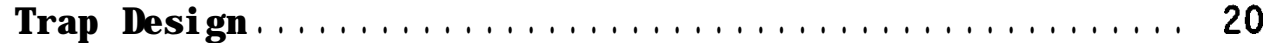

Other Activities $\ldots \ldots \ldots \ldots \ldots \ldots \ldots \ldots \ldots \ldots \ldots \ldots \ldots, \ldots \ldots \ldots$

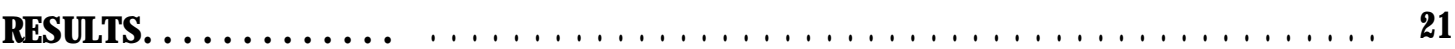

Three MI e Fal Is Dam J uveni I e Bypass Faci I ity

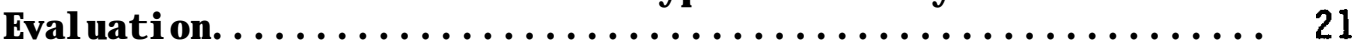

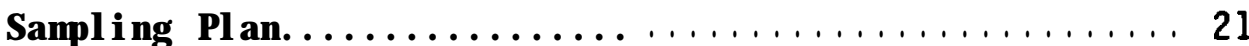

Preparatory Acti vities..................... 36

Upri ver Acti vi ti es at Maxuel I and Westl and

Di versi on Dans.................................... 42

Trap Desi gn .............................. 42

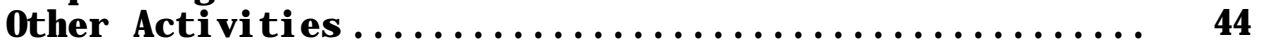

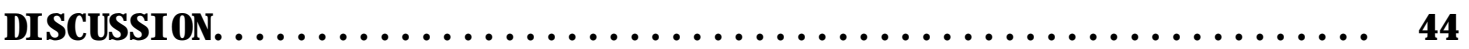

RECOMMENDATI ONS. . . . . . . . . . . . . . . . . . . . . . . . . . . 49

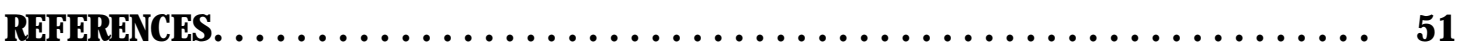




\section{ACKNOVLEDGMENTS}

We appreci at ed the $i$ nvol venent and cooperati on of numerous agenci es and i ndi vi dual s duri ng our study preparati ons. We especi al I y thank Robert Muel ler of our staff for his val uable contri buti ons to the sampling pl an, study preparations, and the annual report. We al so thank Robert Mbrgan who greatl y assi sted with fi el d preparations during his empl oynent with the Oregon Department of Fi sh and $V^{*} I$ dl ife. In our efforts to design fyke nets and hol di ng facilities, we appreci ated the gui dance and assi stance of Duane Neitzel and ot her staff of Battel le, Paci fi c Northuest Laboratories, Steve Rai ney of Nati onal Mari ne Fi sheri es Servi ce, Ti $\mathrm{m}$ Wal ters and ot hers from the Oregon Department of Fi sh and $V^{\prime \prime l}$ dl if e (ODFW Corval I is), A Sol onsky of Hosey \& Associ ates, Harry Senn of Fi sh Manangement Consul tants, and J oel Hubble of the Yaki ma I ndi an Nati on Fi sheri es staff. M ke Fl esher (ODFW La Grande) provi ded us wi th brandi ng equi pnent and i nstructi on. J erry Harmon of the Nati onal Mari ne Fi sheri es Servi ce suppl $i$ ed us wi th the necessary brand tool s. Ken Homol ka (ODFW Spri ngf i el d) provi ded i nf or mat i on and gui dance on the use of fish dyes. We appreci ated the skills of Bryce Lundqui st and Di ane Wyss of the CDFWengi neering staff who drafted a fi nal drawi ng of the Maxuel I bypass trap. We thank Bi II Behrends of the U. S. Fi sh and $V^{\prime \prime} I$ dl ife Servi ce for the loan of a fi eld of $i$ ce trailer. We al so thank Trent Sti ckel I and Ray $\mathrm{HIII}$ of ODF and Tom Shel drake of the U.S. Fi sh and Vild i fe Servi ce for hel pi ng with the procurement of test fish. We thank Bob Becker and Bill Duke of ODFWfor ai di ng in fi sh transport preparations. We thank Gerry Rowan of the Conf ederated Tri bes of the Unati l I a I ndi an Reservation and his techni ci ans for thei $r$ assi stance i $n$ fi sh hol di ng preparations and noni toring at the M nthorn accl i mati on pond. We thank Dal e WII cox and Spencer Day of the U.S. Bur eau of Recl anati on for provi ding techni cal support at the WEID facility during site preparation. We uould al so like to thank Jerry Franke of the West Extensi on I rrigati on Di strict for his support and cooperation. We thank Whye Koval ka of the ODFWengi neering staff for hi s ti me spent educating us in Wéstl and Damfi sh facility operations.

We al so extend our appreci ati on to J ay Marcotte and J erry Bauer of the Bonnevi ll e Power Admi ni strati on for thei $r$ assi stance with contracting of funds. We thank Tony $N$ gro and Enery Wigner for thei $r$ critical revi ew of the manuscript. 
We report on our effort from October 1990 through March 1991 to prepare for the eval uation of the $j$ uveni l e fi sh bypass facility in the West Extensi on I rri gati on Di strict Canal at Three M I e Fal Is Dam on the Unatilla Ri ver. We al so report on our prel i mi nary acti vi ti es to prepare f or f ut ure eval uati ons at Mexwel I and Westl and di versi on dans. A detai l ed sampl ing pl an was written to gui de our efforts in the eval uati on process and associ ated preparat ory acti vi ti es uere conducted. In the sampl ing pl an, we devel oped experi mental desi gns for eval uating the passage of $j$ uveni $I$ e sal moni ds through the bypass system i ncl udi ng the eval uati on at desi gn fl ow of i nj ury and mortality rates, and passage of $\mathrm{j}$ uveni le sal noni ds through and over the screens. We desi gned and fabri cated fyke nets for screen l eakage tests, and hol di ng faciliti es for test fi sh. Modi fi cati ons to i mprove eval uati on acti vi ti es were i ncorporated i nto the col lecti on facility, and our sampling gear. We desi gned and $f a b r i$ cated col l ecti on systens for the $j$ uveni l e $f$ i sh bypass faci I i ti es at Maxuel I and Wéstl and di versi on dans. Prel i mi nary moni tori ng of system operati on was performed at Westl and Di versi on Dam We of fer recomendati ons for i mproving preparations and desi gns of fut ure eval uati ons, and al so recommend that a detai l ed eval uat $i$ on of the Maxuel I and West I and j uveni I e faci I i ti es, i ncl udi ng eval uati on of fi sh conditi on and $f i$ sh passage through or over the screens, be conducted.
\end{abstract}




\section{INTRODUCTION}

\section{Backgr ound}

The Nort hwest Power PI anni ng Counci I' s ( NPPC) Col unbi a Ri ver Basi $n$ Fi sh and Vild ife Program (1987) di rected the constructi on of anadronous fi shery enhancenent projects in the Unatilla River Basi $n$ in the form of passage i mprovenents (Secti on 1403, Measure 4.2). Under contract with the Bonnevill e Power Admi ni stration (BPA) and in cooperati on with the Conf eder ated Tri bes of the Unti I la I ndi an Reservati on (CTU R) and fi sh and wi I dl i fe agenci es, the U.S. Bur eau of Recl anati on (USBR) devel oped and i mpl emented a program to i mprove fi sh passage facilities at Unatilla Ri ver di versi on dans. State- of-the-art passage faciliti es at Three Mle Fal Is Dam vere the fi rst to be constructed, fol l owed by Maxuel I and Col dspri ngs di versi on dans. Westl and Di versi on Dam passage faci I i ti es uere reconstructed under the di recti on of the Oregon Department of Fi sh and $V^{\prime \prime I}$ dl ife (ODFW. Passage facilities at Stanfi el d Di versi on Dam are currently in the desi gn phase by ODFW staff. New screeni ng facilities are i ntended to prevent juveni le sal noni ds from enteri ng the i rri gation canal s by gui di ng them unhar ned back to the river from whi ch they were di verted. Eval uati on of the passage i mprovenent projects at the five naj or di versi on dans on the Unatilla Ri ver was suggested in A Comprehensi ve PI an for Rehabilitation of Anadronous Fi sh Stocks in the Unati l l a Ri ver Basi n (Boyce 1986).

Construction of si milar fish passage and protection facilities at maj or (Phase I) i rri gati on di versi ons i n the Yaki ma Ri ver Basi $n$, Whishingt on, has al so been funded by BPA and USBR under Secti on 803 (b) of the NPPC s Col unbi a Ri ver Basi n Fi sh and $V^{*} l$ dl i fe Program (NPPC 1987). Eval uati ons of the effecti veness of these fi sh screening faci I iti es on the Yaki ma Rer have been carried out by Neitzel et al . (1985, 1987, 1988, 1990a, 1990b) and Hosey \& Associ ates (1988, 1989, 1990). We consi dered thei $r$ experi ences when desi gni ng eval uat $i$ ons of fi sh screening facilities in the Unatilla River Basin.

We began our eval uati on of $\mathrm{j}$ uveni I e fi sh bypass faciliti es i $n$ the Unati I a Ri ver at Three MI e Fal Is Dam i n Novenber 1989 through Sept ember 1990. During thi s peri od, we operated and eval uated the ef fi ci ency of the $j$ uveni l e bypass system in the West Extensi on I rrigati on Di stri ct (VEI D) Canal at Three M I e Fal Is Dam I mprovenents were made to the bypass col lection facilities, a system was devel oped to col I ect $j$ uveni I e sal moni ds at the bypass out fal $I$, and prel i mi nary i nf or nat $i$ on on $j$ uveni l e fi sh passage and fi sh condi $t i$ on was col l ected (Knapp and Whrd 1990).

In this report we descri be our progress from October 1990 through March 1991 touard second year study objecti ves. These st udy obj ecti ves are to (1) eval uate the passage of $j$ uveni l e sal noni ds through the bypass system in the VEID Canal facility at Three MIe Fal Is Dam i ncl uding the eval uati on at desi gn flow of i nj ury and mortality rates, and passage of j uveni l e sal noni ds through and over the screens, and (2) perform prel im nary activities that will facilitate passage eval uations at Maxuel I and Westl and di versi on dans next year. 
Descri pti on of Three MI e Fal Is Dam and the associ at ed VEI D Canal and fi sh screening facilities is provided in our first annual progress report (Knapp and Ward 1990).

Maxuel I Di versi on Dami s I ocated at Ri ver M le (RM 14. 8, 3 miles south of Hermiston, Oregon on the Unatilla Ri ver (Figure 1). The di versi on dam and canal di vert water to serve the Hermi st on I rri gati on Di strict. From the di versi on dam the canal extends $1.5 \mathrm{miles}$ to the fi sh screeni ng faci I ty and fi sh bypass. Reconstruction of the ol d j uveni l e screeni ng facil ity was compl eted in 1989 to comply with revi sed screeni ng criteri a for excl udi ng $j$ uveni l e sal noni ds from the canal and returning them back to the river. Components of the new facility and associ at ed canal struct ure i ncl ude a trashrack, wastewat er channel, three rotary drum screens, a bypass chamber and out let structure, and a canal check structure ( Fi gure 2). The drum screens are 4 ft in di aneter $x 12 \mathrm{ft} I$ ong and are angl ed 24 degrees with respect to canal fl ow Fi sh screened from the canal are di verted into the bypass chamber and carried back to the river vi a 24-i nch di aneter bypass pi pe.

West I and Di versi on Dam i s I ocated at RM 27. 3 on the Unati I l a Ri ver (Fi gure 1). West I and I rrigati on Di strict di verts water through the canal to serve I ands on the uest si de of the ri ver. An i mproved j uveni l e fi sh bypass and hol di ng faci l ity was compl et ed i $\mathbf{n} 1990$. Components of the new faci l ity i ncl ude a trashrack, wast ewater channel, ten 6-ft di aneter $x$ 12-ft I ong rotary drum screens, t no vertical travel ing screens, a pumpback bay with two 9-cubic feet per second (cfs) pumps, fi sh separat or, two fi sh hol di ng ponds, and t wo ri ver return pi pes (Figure 2). Juvenil e fi sh entering the facility are ei ther routed back to the river vi a a bypass pi pe or di verted into a hol di ng pond for trappi ng and haul ing purposes.

\section{METHODS}

Three M I e Fal Is Dam J uveni I e Fi sh Bypass Faci lity Eval uation

Sampl ing PI an

For the eval uat $i$ on of the $j$ uveni l e $f i$ sh bypass system at Three MIe Fal I s Dam we needed to devel op a fi el d sampl ing $\mathrm{pl}$ an to gui de our efforts in conducting the specific tests and other aspects of the study. In formul at ing the sampl ing pl an, we needed to i dentify test fi sh to be used, and test-speci fi c experi mental desi gns, i ncl udi ng rel ease numbers, rel ease and recapt ure methods and I ocati ons, exam nat $i$ on procedures, data needs, and statistical methods. We al so needed to i dent i fy brand marks to be used, facility operation procedures and consi der strategi es for haul ing and hol di ng fi sh.

Experi mental Desi gn: The basi c experi mental desi gn of the eval uati on i ncl uded two types of tests: i nj ury and l eakage. The 


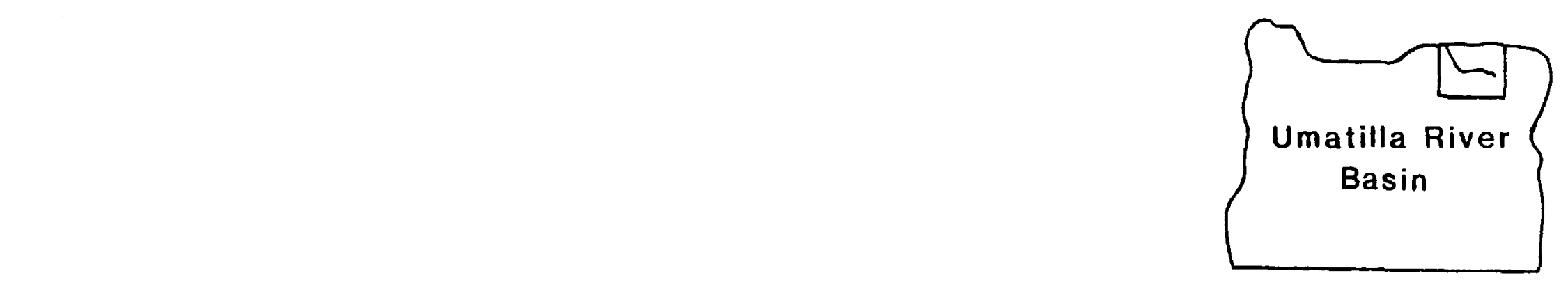

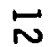

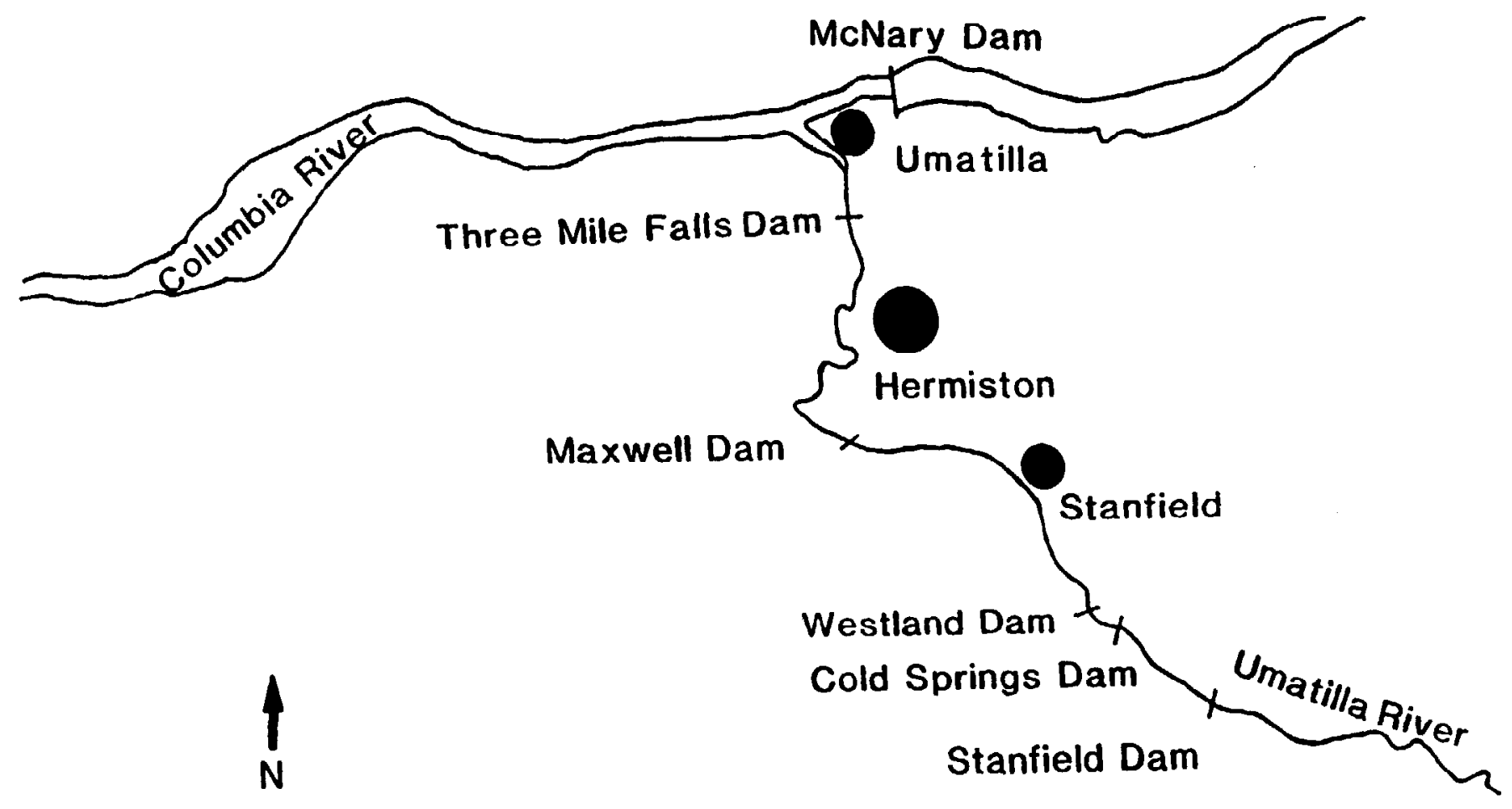

Figure 1. Locations of diversion dams on the lower Umatilla River, Oregon. 

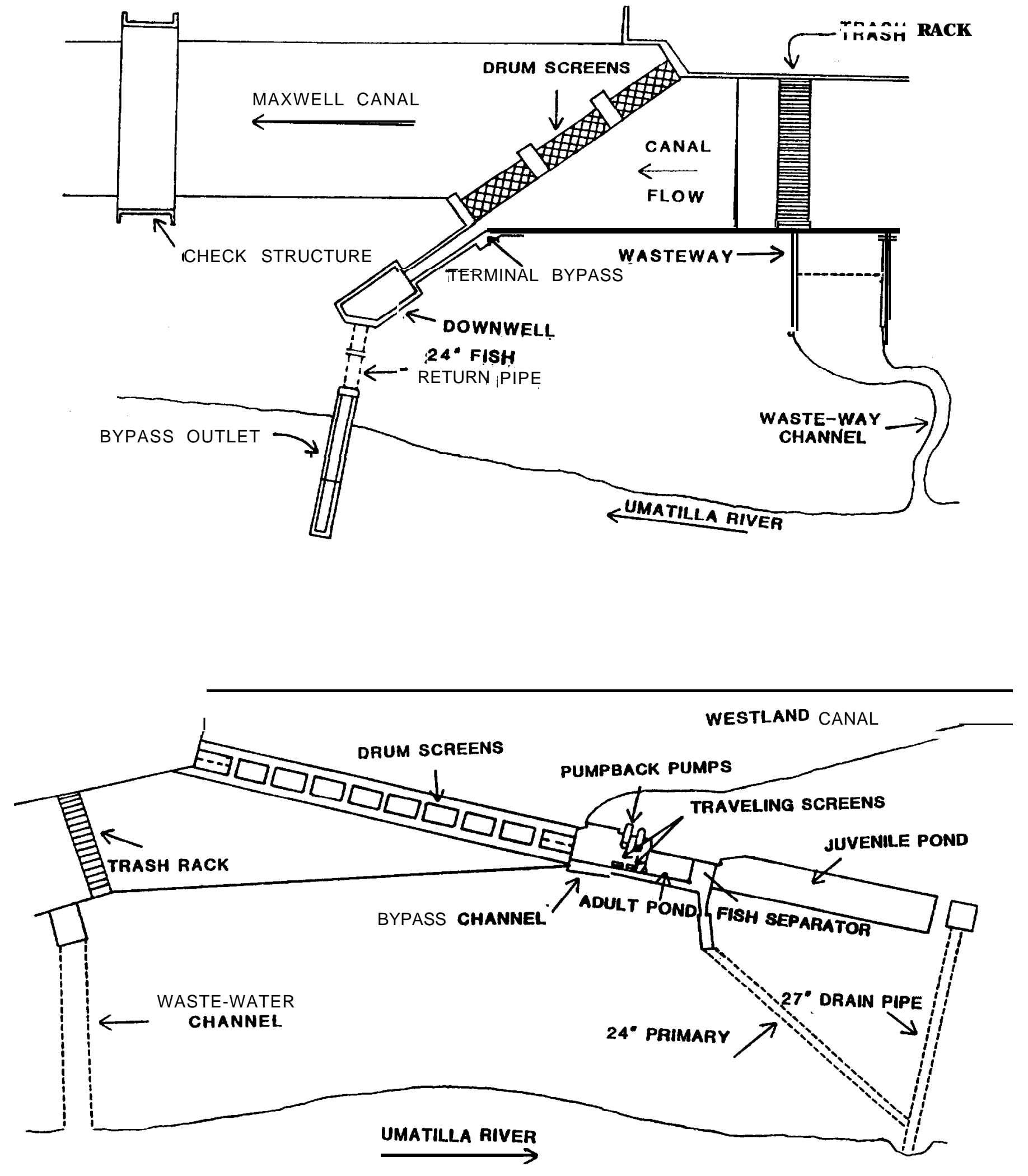

Fi gure 2. Schenti $\mathrm{c}$ of the $\mathrm{j}$ uveni I e fi sh bypass facilities at Maxwel I (upper) and Wéstl and ( I ower) di versi on dans. 13 
pri mary obj ecti ve in the inj ury test was to eval uate i nj ury or i nj uryrel ated nortality of $f i$ sh as they passed by the screens and into the bypass or through the bypass pi pe and out the outfal I. We planned to accompl i sh this by rel easi ng groups of marked fi sh i n vari ous I ocati ons in the screening facil ity, recapt uring them in the bypass or bypass outfal $I$, and inspecting them for mortal ity, descal ing or other inj ury. We al so pl anned to rel ease groups of marked fi sh di rectl y into col l ecti on facilities to assess and compare i nj ury caused by the col I ecti on and handl i ng process. To determi ne i f i nj ury l evel s vari ed wi th anbi ent I i ght condi ti ons, we pl anned to conduct the screen i nj ury tests during the day and ni ght. To determine if i nj ury I evel s vari ed with bypass fl ow we pl anned to conduct the bypass pi pe and outfal I inj ury test at a 5-cfs and 25-cfs bypass flow

Our obj ecti ve in the I eakage test was to eval uate fi sh I oss i nto the canal caused by passage through (ent rai nment) or over (i mpi ngenent) the drum screens by rel easi ng groups of fi sh upstream from the screens, and recapt uring them i $n$ fyke nets set i medi at el y downstream from the screens. We al so planned to rel ease narked $\mathrm{fi}$ sh bet ween the screens and fyke nets and in the bypass channel to eval uate the sampl ing efficiency of the nets and col l ection facil ity, respecti vel $y$.

I $n$ addi tion, we desi red to determi ne if $f i$ sh were I eaki ng past the pumpack bay travel ing screen during operation, and if $f$ i sh were i nj ured as they passed under the canal headgates. These tests vere ancillary to work st at enent obj ecti ves and noul d be performed as secondary tests, if possi bl e.

We desi gnated the pri mary tests as the (1) screen i nj ury test, (2) bypass pi pe and outfal I i nj ury test, and (3) screen l eakage test. Secondary tests uere desi gnated as the (1) travel ing screen l eakage test, and (2) headgate i nj ury test.

Screen I nj ury Test: In desi gni ng the screen i nj ury test, we needed to i dentify rel ease l ocati ons above the screens and det ermi ne sampl ing frequency. Si nce we woul d be col l ecting a $100 \%$ sampl e to recapt ure al I test fish, we vere concerned with how to prevent fish in the transfer f I ume from enteri ng behi nd the sampl e tank crouder during the sample crouding process. We needed to determi ne rel ease and recapt ure strategi es for control fi sh to precl ude di fferential handling bet ween treat nent and control fish.

I n determi ni ng rel ease ti mes for day and ni ght treatment rel eases, we i dentified ti ne of darkness during April and My for the ni ght rel ease. Subsequent day and ni ght rel eases were establ i shed at 12 hour i nt erval s.

The bypass col I ecti on facility at Three MIe Fal Is Dam had been previ ousl y modi fi ed to al I ow ef $f$ i ci ent sampl ing of bypassed $f i$ sh (Knapp and Whrd 1990). An effecti ve anestheti c system nould sati sfy our need to i dentify and separate col lected ri ver-run fi sh from our branded test fi sh, and al l ow us to exami ne test fi sh for i nj ury. A system to recover anesthetized fish and ret urn them back to the ri ver had al so been 
devel oped. Our work in 1989 and 1990 hel ped prepare us for thi s year's sampling efforts and al erted us to problens we might encounter.

We were concerned wi th how to provide consistent I i ghting condi ti ons during the exami nati on process for both day and ni ght tests to el i mi nate bi as i n eval uating i nj ury. To be consi stent, al l fi sh within a particul ar test, incl uding pre-rel ease subsample and recapt ured test fish, needed to be examined in the same manner and under the same condi ti ons. I ndi vi dual subj ecti veness needed to be mi $\mathrm{mized}$ or el i mi nat ed.

Our data needs for the screen i nj ury test were to docunent condi ti on of treatment and control fi sh in the form of scal e loss or ot her i nj ury, the number of treat ment $f i$ sh recapt ured and $t i$ me of recapt ure, and nortal i ti es. I nci dent al i nf or nati on i ncl uded the documentation of facility operations.

Bypass Pi pe and Outfal I I nj ury Test: In previ ous efforts, we had desi gned, fabri cated and tested a fl oating net pen for the bypass outfal I test to capt ure the maj ority of fish exiting the outfal I (Knapp and Ward 1990). In desi gni ng the bypass pi pe and outfal I inj ury test, speci al consi derati on was gi ven to how and when control fi sh were to be rel eased i nto the net pen, where treat nent fi sh were to be rel eased, how $f i$ sh were to be recovered from the net pen, and where exami nati on for i nj ury was to occur. We al so needed to know the operati onal procedures for setting a 5-cfs and 25-cfs outfal I fl ow Other concerns were whether associ ated control and treat ment groups shoul d be rel eased i nto the net pen together or separatel $y$, the l ength of ti me the net pen shoul d be hel d in pl ace to recapt ure the maj ority of treatment fi sh, and what method to use to restrict fl ow through the bypass to facilitate pl acenent of the net pen.

Our concerns during the exami nation process were si milar to those for the screen i nj ury test. To be consi stent, al I fi sh needed to be exami ned in the sane manner and under the same condi ti ons. Recovering fish from the net pen at the base of the bypass outfal I requi red that fi sh be exami ned in cl ose proxi mity. Requi renents such as hol di ng, processing, recovery and di sposal of fi sh at this I ocati on needed to be addressed.

Data needs for the bypass pi pe and outfal I inj ury test were the sane as those for the screen inj ury test.

Screen Leakage: Devel opment of an experi nental desi gn for the screen I eakage test requi red a deci si on on a capt ure met hod. We deci ded on a seri es of fyke nets behi nd each of the four drum screens ( see Preparatory Activiti es). Other consi derati ons were where and how to rel ease treat nent and control fish, how to differentiate treat ment fi sh from control fish, and the frequency and duration of "sampl ing" after each rel ease to ensure recapt ure of the majority of fish. In our deci si on to use fry in thi test, we could not brand the fish due to thei $r$ smal I si ze whi ch precl uded our ability to differentiate rel ease 
groups. Ther ef ore, successi ve test rel eases needed to be spaced far enough apart to avoi d recapturing previ ousl y rel eased test fi sh.

A sampl ing mode nould be requi red at the col I ecti on facil ity to recapt ure treat ment $f i s h$ and control fi sh rel eased in the bypass channel. When i n a sampling node, a 20-cfs fl ow shoul d be di verted from the bypass channel back to the canal or to the river. We were prevented in usi ng the pumpback pumps to di vert the uater into the canal because the turbul ent di scharge woul d i nterfere with fyke net col l ecti on effici ency. Ther ef ore, we were restricted to di schargi ng the 20-cfs fl ow through the river return drai $n$ pi pe. We could onl y monitor screen I eakage of ri ver-run fi sh when pumpback pump operation was not requi $r e d$.

ar specific data needs were the number of control fish and the number and l ength of treatment fish in the fyke net, the number of control and treatment fi sh col l ected in the sampl ing tank, and observati ons of "rol l over" or screen i mpi ngenent.

Travel ing Screen Leakage Test: We had a concern on whet her fi sh were getting by the travel ing screen bottom seal s or screen mesh and entering into the pumpback bay. To test for I eakage, we consi dered opti ons on where, when and how to capt ure fi sh.

Headgate I nj ury Test: We wanted to know if fi sh were bei ng i nj ured as they passed under the headgates into the canal facility.

Avai lability of test fish was our major constraint. Experi mental design nould be si milar to the screen inj ury test.

Test Fi sh: We desi red to use the sane fish species that were present in the Unatilla River system Appropriate information could then be obtai ned on species and si ze specific behavi or and potential for i nj ury or l eakage in the passage facility. We desi red to use fry-sized fish for the screen I eakage test si nce these fish would be potential Iy vul nerable to entrai nment and i mpi ngenent shoul d nat ural producti on i ncrease in the l ower river in the future. For our tests, we want ed to procure unmarked ( no CWr) production fish desti ned for rel ease in the Unati I I a Ri ver.

The proposed number of $\mathrm{fi}$ i $\mathrm{in}$ each rel ease group had been revi ewed and approved by an CDFW st aff bi onetrician. These numbers were based on sampl e si zes used by previ ous researchers (Fast et al. 1986, Hosey and Associ at es 1988), but were nodi fi ed based on si ze of the VEI D facil ity, expected recapt ure rates, and expected vari ati on i $n$ resul ts anong rel ease groups. We cal cul ated the total number of test fish needed for the screen inj ury, bypass outfal I i nj ury, and screen I eakage tests from the requi red number of treat nent and control rel eases, rel ease groups, and fish per group for each test category.

Test Schedul es: Test schedul es were pri narily determi ned by fi sh avai lability from hatcheries. Fi sh avai l ability was contingent on 
attai nnent of a desi red target si ze. We al so want ed to avoi d conducti ng tests with a specific speci es when I arge numbers of hat chery rel eased fi sh of the sane speci es vere expected to be in the river system

Other consi derati ons in schedul ing day-to-day acti vi ti es were the ti me requi red for branding and brand-setting, for carryi ng out tests or other activities, and for appropriate numbers of test fi sh to be recovered in a test.

We al so consi dered ease and ef fi ci ency i $n$ equi pnent depl oynent and changi ng modes of operation when pl anni ng the sequence of tests. The di fficul ty i $n$ depl oyi ng the bypass channel sampl i ng equi pnent and the ti me that it consuned favored the scheduling of al $\mathbf{l}$ screen inj ury tests back-to- back. Thi s woul d mi ni me equi pment changes and al l owed a greater l ength of ti ne for total recapture for al I screen i nj ury test rel eases.

Brands: We were to mark fi sh usi ng freeze-brands. Brand marks needed to be uni que between al I treatment and control rel ease groups to permit differentiation. Fi sh I ength, number of repl i cat es, and desi red number of brandi ng stati ons were factors in determini ng number, si ze and type of brand to use. For consi stency i n readabi lity, al I brands needed to be of the same series. Brands needed to be procured from the Nati onal Mari ne Fi sheri es Servi ce.

Exami nati on: Criteri a used for the eval uati on of descal ing or other inj ury needed to be consistent with criteria used el sewhere in the Col unbi a Ri ver Basi $n$ for comparati ve purposes.

Data Anal ysi s: Our pri mary goal i $n$ the eval uati on of i nj ury was to determine if fish were inj ured or killed during thei $r$ passage through the screening facility and as they were di verted back to the river. We needed to ascertai $n$ if there uas si gni ficant differences in i nj ury bet ueen treat ment and control fi sh from the vari ous tests to det ermi ne if i nj ury was facility-caused. In this anal ysis, we needed to take into account affects of the collecti on systens and the handl ing process on fi sh condition, and pre-rel ease condition of the fish. Data on i nj ury needed to be col l ected, mani pul ated and presented in a manner that was conduci ve to anal ysi s and compari son wi th resul ts from ot her st udi es. The ability to pool the data from the various rel eases and tests to reach a hi gher l evel of conf $i$ dence was an i mportant consi deration. We consi dered various statistical tests that nould provi de us with the i nf ormation we wanted with the type of data we were collecting.

We were al so concerned with travel ti me through the facility. The ti ne requi red to recapt ure $50 \%$ and $95 \%$ of the test rel eases in the collection facility or at the bypass outfall nould provide us with an overal I esti mate of system ef $\mathrm{f}$ ici ency in ret urning fi sh back to the ri ver. 
The data collected from the screen l eakage tests noul d test the nul I hypothesi s that no fi sh pass through the drum screens and ent er the i rrigati on canal and al I fish that encount er the drum screens are gui ded i nto the bypass. To carry out the computati ons for determining screeni ng effici ency, we woul d need to determi ne bypass and net coll ection ef $\mathrm{i}$ ci ency.

\section{Preparat ory Acti vi ti es}

Haul ing and Hol di ng: We needed to deterni ne a method for transporting test fish from hatcheries to a nearby temporary hol ding si te pri or to use in the eval uation. This method shoul d be efficient and non-i nj urous to fish.

To determine a temporary hol ding I ocation for al I the test fi sh, we eval uated the merits and feasi bility of hol ding fish on-site at Three MI e Fal I s Dam vs. a near by hatchery or accl i mati on pond. I $n$ both cases, speci al consi derati on was gi ven to space avai lability, staff needs, and $f i$ sh handl $i$ ng requi rements.

If hel d off-site, we needed to devel op a nethod for haul ing the vari ous fish species to the test site when needed. Wh consi dered avai I abl e transport vehi cle opt i ons, thei $r$ accessi bi l ity, conveni ence, si ze, and ease in I oadi ng and unl oadi ng $f i$ sh. We desi red to I oad and unl oad $f i s h$ with the l east amount of handl ing. The transport met hod uoul d need a suffici ent oxygen suppl y system and not be stressf ul to fish.

We needed to desi gn a system for recei vi ng and hol di ng a speci fic group of test fish at the site pri or to branding. We considered ease of unl oadi ng wi thout i nj ury to fish, avai lability of a suffici ent water suppl y system space avai labi lity, fi sh accessi bility for branding or monitoring, and safety and wel fare of the fish.

Af ter brandi ng, we needed i ndi vi dual contai ners to hol d the separate rel ease groups. Consi derati ons in sel ecti ng appropri ate contai ners were adequate capacity, avai lability, cost, versatility, ease i $n$ handling and i $n$ accessi ng and rel easi ng fish, and capabi I ity of al I owing sunl $i$ ght penet ration wi thout fi sh escape. An associ at ed uater suppl y or oxygen system was al so a concern.

A water suppl y system noul d be requi red to provi de adequate i nf I ow for fish survi val. This system needed to be conduci ve to our sel ected fi sh hol di ng arrangenent. We consulted with bi ol ogi sts from the Yaki ma I ndi an Nati on, ODFW Battel I e, Paci fi c Northuest Laboratori es (PN), and Hosey \& Associ ates in devel oping i deas for hol ding facilities and an associ ated water suppl y system

Marki ng: We consi dered I ocati on, equi pnent needs, and saf ety concerns in devi si ng a workable brandi ng system We wanted a system that was non-inj urous or stressful to fi sh and ef $f$ ici ent in operation. 
We consul ted with others proficient in brandi ng to I earn specific techni ques and use and care of equi pment.

We had to devel op a marking method for the fry-sized fi sh to be used in the screen l eakage test si nce treat ment and control fi sh needed to be differentiated to effectivel y run the test. The smal I size of the fi sh precl uded branding. We consul ted with other bi ol ogi sts and consi dered thei $r$ experiences in devi si ng a marking method.

Trap Desi gns: To ai de us i n our eval uati on of drum screen I eakage, we needed to desi gn a system that woul d capt ure fi sh i $n$ the VEI D Canal behi nd the drum screens. Si nce $\mathrm{j}$ uveni I e fi sh had been observed i $n$ the canal downst ream of the drum screens (Knapp and Whrd 1990), it was i mport ant to know from whi ch screen(s) I eakage was a potential probl em We deci ded on a system of fyke nets behi nd each of the four drum screens. Pri or to the desi gn of fyke nets, we consulted with bi ol ogi sts from Battel I e, PN on thei $r$ approach to fyke net and fyke net frame desi gn used in Phase I fi sh screening facility eval uations in the Yaki ma Ri ver Basi $n$.

I n our deci si on to use fyke nets, we consi dered ease of depl oyment, cost, effi ci ency, ef fecti veness and operati onal constrai nts. We i nspected the VEI D Canal si te behi nd the drum screens to det ermi ne exact specifications for the fyke nets. We measured avai I able di stance downst ream of each screen to the canal wal I, angl e of canal wall, depth, angl e, vol um and vel ocity of water fl ow through the screens, and drum screen width. We used si mple trigonomic functions to determ ne correct si de I engths and corner angl es for each of the four respecti ve nets. The unequal si des and correspondi ng angl es noul d al I ow the nets to I ay parallel to the angle of the flow Mesh size was contingent on $f i$ sh si ze. We al so consi dered means for effici ently removing fi sh from the cod end.

We patterned the fyke net franes after the baffle board frames al ready i nstal led behi nd the drum screens i $n$ the VEI D Canal for use i $n$ fl ushi ng out bottom silt. We i ncl uded mi nor modi fications for fyke net attachment. We measured frame wi dth and depth, number, wi $\mathrm{dth}$ and spacing of baffle boards, and di stance bet ween frane I ifting brackets.

For the travel ing screen l eakage test, we eval uat ed condi $t i$ ons at the terminus of the ri ver return drai $n$ pi pe whi ch drai ns the pumpback bay, and deci ded thi s was the onl y l ogi cal l ocation for col l ecting fi sh that may l eak past the screen. We sel ected a fyke net design at the pipe terminus as the nost practical and effective neans of capt uring fish To desi gn the fyke net and frame, we neasured the I ength and depth of the di scharge pool, and di aneter and position of the pi pe terminus, and esti mated fl ow and vel ocity of the di scharge water. We consi dered how to secure the net frame to the cenent wall, and efficient depl oyment and retrei val methods.

Equi pment Needs: We assessed equi pment and gear needs in accordance with each eval uation activity. We consul ted with other 
bi ol ogi sts to determine what uorked best for them and researched avai I abl e suppli ers. We consi dered saf et $y$, fi sh handl i ng, data coll lection, equi pnent operation, and personnel in deci ding on the type of gear and equi pnent we needed.

Facility and Gear Modifications: After sampling activities in 1990, we i dent i fi ed areas for modi ficati on and i mprovenent to enhance eval uati on acti vi ti es in 1991. These i ncl uded modi fi cati ons to the sampl i ng tank, nodi fi cati ons to our sampl i ng gear, and mor modi $\mathrm{i}$ cations to the si te.

Personnel: Personnel needs were determi ned based on the summati on of activities that we nould be performing and the number of persons requi red to performeach acti vity. We were to operate a daily, 24-hour st udy that woul d requi re suffici ent fiel d personnel to haul, monit or and brand the fish, and perform the tests.

\section{Upri ver Acti vi ti es at Mexuel I and Westl and Di versi on Dans}

Our second objective in thi s year's efforts was to perform prel i minary acti vi ti es that woul d faci l i tate $j$ uveni l e fi sh passage eval uat $i$ ons at Maxuel I and West I and di versi on dam $f i$ sh bypass facilities. To meet this obj ective, we were to operate and eval uate the ef $f i c i$ ency of the $j$ uveni I e $f i$ sh bypass system at Westl and Di versi on Dam and desi gn bypass and bypass outfall capture facilities for the Maxuel I and West l and $\mathbf{j}$ uveni $\mathrm{I}$ e sal moni d bypass systens.

\section{Trap Desi gn}

We conducted site-specific eval uations at Maxuel I and Westl and di versi on facilities in the fal l of 1990 to assi st in devel oping desi gns for bypass channel coll ection traps for $f$ ut ure eval uations. To f urther assi st in desi gni ng bypass traps, we consul ted wi th bi ol ogi sts from Battel le, PN who had performed si milar eval uations at Yaki ma Ri ver Phase I fish screening projects. We al so toured the Phase I and Phase I I (snal I to medi um) fi sh screeni ng facilities in the Yaki ma Ri ver Basi $n$ to familiarize oursel ves with facility design and operations. We consul ted with bi ol ogi sts from National Mari ne Fi sheries Servi ce who uere i nstrumental in devel oping operating criteria for the Unatilla River fish passage facilities.

Structural and operati onal features used to determi ne appropriate trap desi gn for the bypass channel at each dams screeni ng facility i ncl uded conf $\mathrm{i}$ gurati on of the bypass channel and bypass downuel I., naxi mum desi gn bypass fl ow hei gth of water surcharge over the channel wei $r$ at maxi mum desi gn fl ow avai $I$ abl e struct ures for trap securenent and depl oyment, and access. In our desi gn process, we consi dered how to el i mate water during fi sh collection, adj ust the trap with fl ow 
f I uct uat i ons, ef $\mathrm{f}$ i ci ent l y col l ect fi sh i n a non- $i$ nj urous nanner, and effici ent ly depl oy, retri eve and cl ean the trap.

The desi gn of the fi sh screeni ng and hol di ng facility at Westl and Di versi on Dam was constrai ned by a l ow head di fferential bet ween the facility and the river. El enents of this design rel ating to the bypass channel conf ounded our attempts to desi gn a bypass channel trap. We i nspected the struct ure and conf $i$ gurati on of the bypass downuel $I$ and determined that it would be difficul t to locate a trap in this area. Subsequent $l y$, we turned our attenti on to the $j$ uveni l e sal moni $d$ hol di ng pond as a potential trap location. Stopl og gui des at the entrance to the pond suggested a fyke net desi gn to be nost appropriate. We neasured the stopl og gui des, and determi ned pond water depth and i nf I ow current during normal operations. Our concerns were how to effectivel y cont ai $n$ and access the collected fish, and how to depl oy and ret rei ve the net.

\section{Other Acti vi ti es}

To familiarize oursel ves with the desi gn and operation of the j uveni I e fi sh bypass facility at Westl and Dam we revi eued operating criteria and inspected the facility in depth with ODFWengi neering personnel both during and after construction. We al so monitored j uveni I e sal noni d trap and haul operati ons when possi bl e.

We i nvesti gated the condi ti on of the wastewater channel at the Maxuel I Dam fi sh screening facility. We were concerned with the potent $i$ al for fish passage and i nj ury during overfl ow periods and wi th fi sh st randi ng duri ng peri ods of overfl ow abat enent.

\section{RESULTS}

Three MIe Fal Is Dam Juveni I e Fi sh Bypass Facil ity Eval uati on

Sampl i ng PI an

Experi mental Desi gn: We will segregate the eval uati on of the j uveni l e fi sh bypass facility at Threemile Fal Is Dami nto different tests in order to eval uate vari ous components of the facility at desi gned operating criteria and flow The pri mary tests to be conducted i ncl ude the screen i nj ury, bypass pi pe and outfal I i nj ury, and screen I eakage tests. Secondary tests i ncl ude travel ing screen I eakage and headgate i nj ury tests. We will conduct these tests with different speci es or races (si zes) of juveni l e sal moni ds in Apri I and Myy of 1991.

Screen Injury Test: To eval uate i nj ury and nortal ity rates associ ated with the drum screens, we wil rel ease repl $i$ cate groups of heal thy, f r eeze-branded $f i$ sh upst ream of the drum screens, recapt ure them at the bypass collection facility, and examine the fish for descal ing and ot her inj uri es (treat ment). We will al so rel ease repl i cate groups of heal thy fish di rectly into the collection facility 
( sampl e tank) to al I ow us to eval uate i nj ury caused by the col l ecti on and handling process (control).

We will conduct tests during the day and at ni ght from mid-April to mid- Myy when fi sh are avai I able (Figure 3). Wh will repeat each test on three di fferent dates at maxi mum desi gn fl ow for each speci es or race of test fish. Each treatment and control, day and ni ght rel ease will consi st of three 100-fish groups. For each speci es or race of test fish, total number of rel ease groups will be 36 and the total number of fish will be 3,600 ( 2 groups (treatment $t$ control) $\times 2$ tests (day $t$ ni ght) $\times 3$ rel eases (dates) $\times 3$ groups per rel ease $\times 100 \mathrm{fi}$ sh per group = 3, $600 \mathrm{fi} \mathrm{sh}$; Tabl e 1).

We will adhere to operation criteri a for a sampling node when capt uring rel eased test fish in the collection facility. This incl udes the i nstal I ati on of sampl ing equi pment ( or i fice pl ate, i ncl i ned screen, $f i$ sh separat or), and operati on of the travel ing screen and pumpback pumps, and the proper setting of wei $r$ gate positi ons and headworks water I evel s (USBR 1989). If bypass fI ow does not need to be ret urned to the canal, we will open the El-i nch di ameter drai $n$ pi pe gate to ret urn water to the river.

We will exami ne a $10 \%$ subsampl e from each repl i cate group for condi ti on pri or to rel easing them to ascertai $n$ pre-rel ease condi tion. We will I ater compare this pre-rel ease condition with the condi ti on of fish after they have been handled. These subsample fish will not be returned to thei $r$ groups. We will rel ease, recapt ure and process each day and ni ght control group as we recapture previ ousl y rel eased test groups. he will rel ease groups of control fi sh di rectly i nto the col l ecti on faci I ity sampl e tank and wi I handl e them duri ng exami nation in the same manner as the treat nent fish. We will rel ease treatment groups i medi at el $y$ bel ow the headgates in each of three fl ume secti ons in the canal headuorks (Fi gure 4). We will rel ease day and ni ght treat ment groups at approxi matel y 0900 hours and 2100 hours, respectivel y, for three consecutive 24-hour periods. Wh will record rel ease i nf or nati on on a screen i nj ury rel ease form

We will recapture treat nent fi sh in the sample tank at the bypass col l ecti on faci I ity ( Fi gure 4). W" th sampl ing equi pnent i $\mathrm{n}$ place, fi sh will enter the bypass channel through the orifice plate, nove up the i ncl i ned screen and onto the fi sh separator, and travel al ong the transfer fl une to the south hol di ng (sample) tank. We will croud and renove the fish from the tank every hour to determine travel ti ne and begi $n$ processing. Sampl e tank crouding nay occur nore frequentl y if the tank becomes too ful I of i nconing fish. To prevent fish fromentering the tank behi nd the crouder during crouding, we will insert a slide gate into the fish separat or to hol d i ncoming fish temporarily. We wi I conti nue to recapt ure treatment fi sh for 96 hours after the I ast treat ment rel ease group to al l ow suffici ent ti me for a $95 \%$ recovery. We will record the ti ne of rel ease and recapt ure to ascertai $n$ novenent rates through the facility.

We will separate river-run fi sh that are col l ected during the eval uation from the test fish and return themto the river. Ut will 


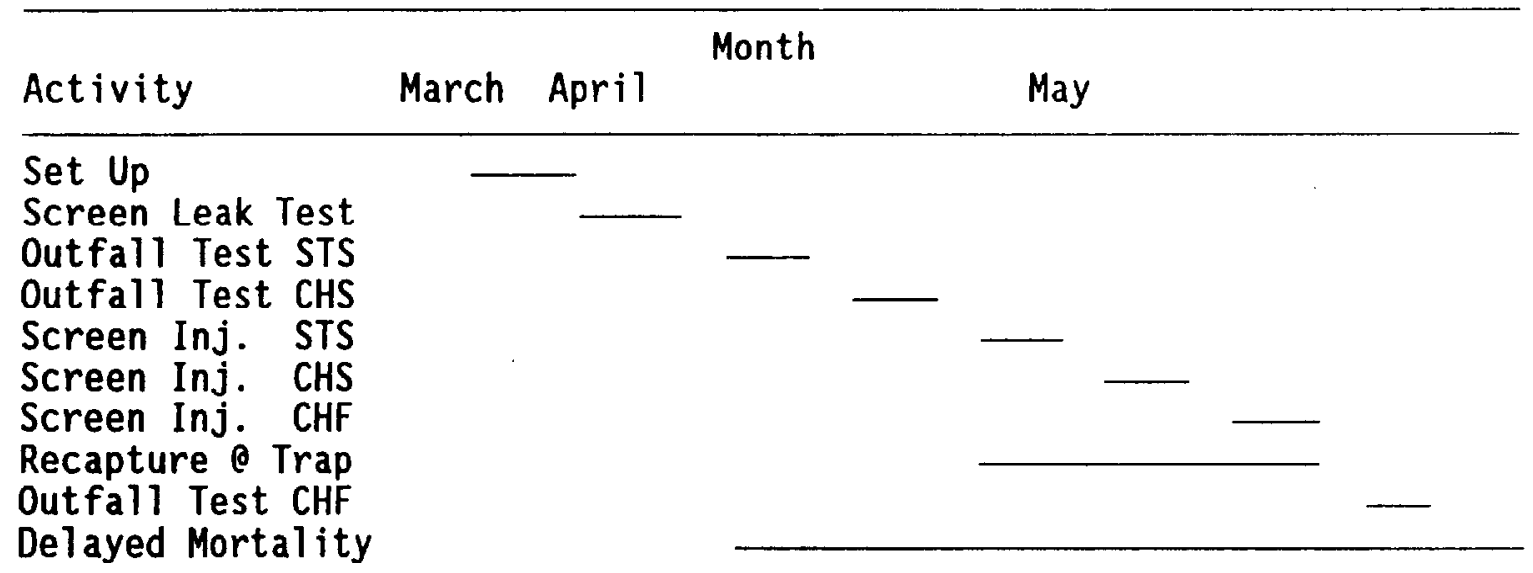

Figure 3. Schedule of evaluation activities at the WEID Canal juvenile fish bypass facility at Three Mile Falls Dam, Spring 1991. 
Tabl e 1. Summary of pri mary test $\mathrm{fi}$ sh rel eases i $\mathrm{n}$ the VEI D Canal at Three Mle Fal Is Dam Unatilla Ri ver, spring 1991.

Fi sh speci es,

Rel ease

Recovery $\mathrm{Nb}$ l ocati on l ocati on rel.

No. of

Total test

Iocation

Fal I chi nook fry: Screen I eakage

Net mouth
Headworks
Bypass

Fyke net Fyke Net

Sampl e tank

$\begin{array}{rrr}75 & 12 & 900 \\ 300 & 3 & 900 \\ 300 & 3 & 900\end{array}$

Fal I chi nook ( $\alpha)$ :

Screen i nj ury e day

Screen i nj ury o ni ght

Bypass outfal I (a) 5 cfs

Bypass outfal I

C 25 cf s

Sampl e tank
Canal
Sampl e tank
Canal
Net pen
Downuel I
Net pen
Downuel I

Sampl e tank
Sampl e tank
Sampl e tank
Sampl e tank
Net pen
Net pen
Net pen
Net pen

100

100

100

100

100

100

100

rel eases rel.

\section{Spri ng chi nook (1+) \\ Screen i nj ury c day \\ Screen i nj ury \\ e ni ght \\ Bypass outfal I \\ e 5 cfs \\ Bypass outfal I \\ c 25 cf s}

Sampl e tank
Canal
Sampl e tank
Canal
Net pen
Downuel I
Net pen
Downuel I

Sampl e tank Sampl e tank

100

100

Sampl e tank

100

Sampl e tank

100

Net pen

100

Net pen

100

Net pen

100

Net pen

100

$\begin{array}{ll}9 & 900 \\ 9 & 900 \\ 9 & 900 \\ 9 & 900 \\ 9 & 900 \\ 9 & 900 \\ 9 & 900 \\ 9 & 900\end{array}$

Summer st eel head

Screen i nj ury

@ day

Screen i nj ury

e ni ght

Bypass outfal I

c 5 cfs

Bypass outfal I

@ 25 cf s

Sampl e tank
Canal
Sampl e tank
Canal
Net pen
Downuel I
Net pen
Downuel I

Sampl e tank

Sample tank

100

100

100

Sampl e tank

100

100

Net pen

Net pen

Net pen

100

100

Net pen

100

$\begin{array}{ll}9 & 900 \\ 9 & 900 \\ 9 & 900 \\ 9 & 900 \\ 9 & 900 \\ 9 & 900 \\ 9 & 900 \\ 9 & 900\end{array}$

1 Actual rel ease nunber wil be approxi natel y 90 for al inj ury tests

( 100 mus the $10 \%$ pre-rel ease subsample). 


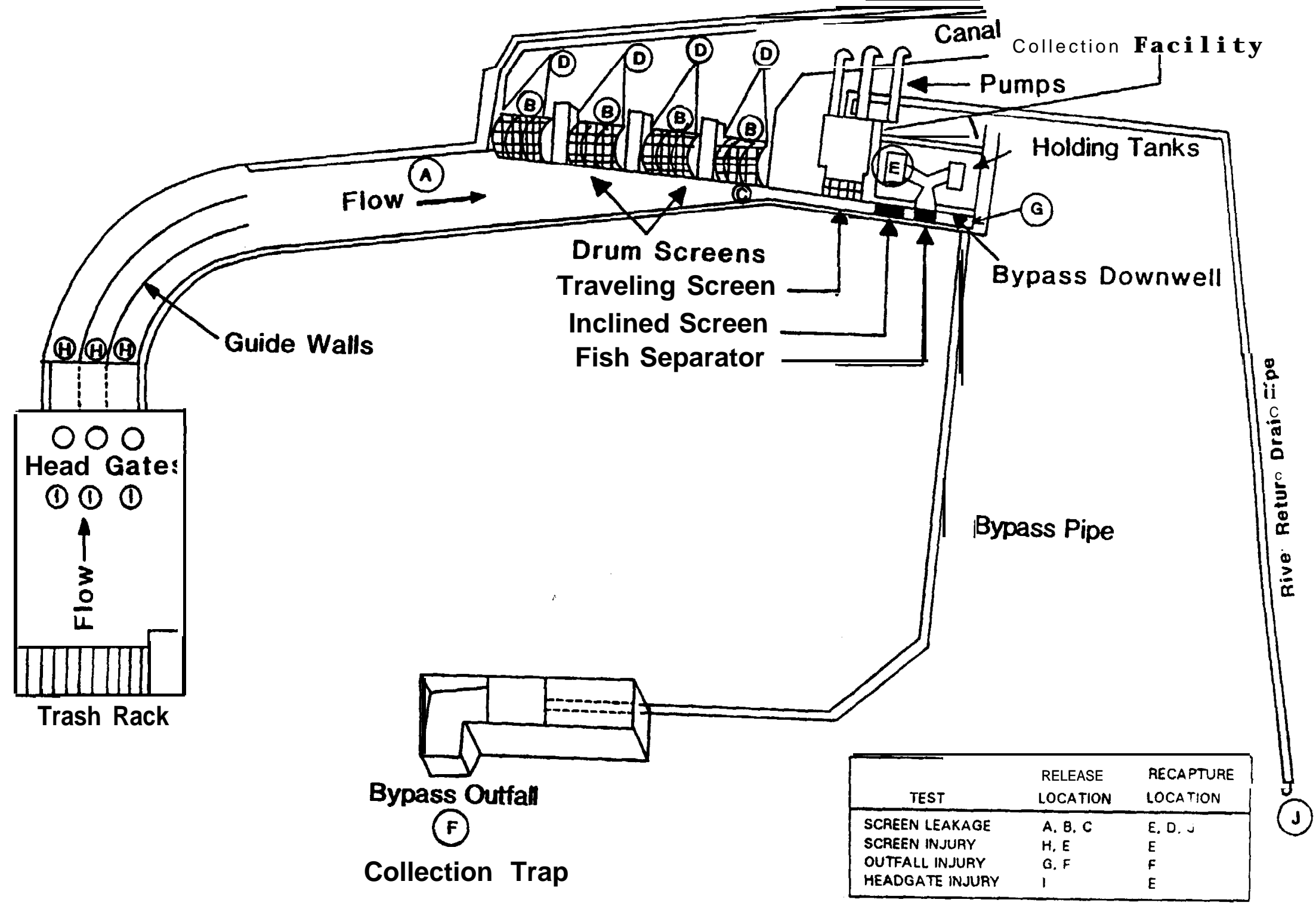

Fi gure 4. Schenatic of the VEI D Canal $j$ uveni I e fi sh bypass faci lity at Three M le Fal Is Dam incl uding sampling l ocations for rel ease and recapt ure of $\mathrm{fi}$ sh. 
anesthetize al I fish to ascertai $n$ test from river-run fish. We will exami ne test $f i$ sh i medi atel y for descal ing or transfer them to hol di ng contai ners for I ater processing. We will place river-run and test fish in the north hol di ng tank to recover from the anesthetic and then rel ease them into the bypass downuel I.

We wi l exami ne fi sh for descal ing in the col l ection faci I ity during day and ni ght rel ease tests. An overhead canopy will provi de protecti on fromt he weat her and a hi gh pressure sodi um I amp di rectl y above the nork table will provi de consi stent I i ghting conditi ons for day and ni ght exami nations. We will retrei ve control and treatment fi sh from the collection tank, pl ace them in an anesthetic trough, and anest hetize them with Fi nquel (MS222). We wi II determi ne condi ti on usi ng descal ing criteri a devel oped by the U.S. Army Corps of Engi neers (USACE) and record it on descaling forms.

After processi ng, we will place treatment and control fish i n cont ai ners to recover and ei ther rel ease them back into the river, or hol d them for use in secondary tests.

Bypass Pi pe and Outfal I I nj ury Test: To eval uate i nj ury and mortal ity rates associ ated with the bypass pi pe and bypass outfal $I$, we wi I rel ease repl i cate groups of freeze- branded heal thy $f i$ sh at the entrance of the bypass pi pe, recapt ure them at the bypass outfal I to the river, and exami ne the fi sh for descal ing and other inj uries (treat ment). We will al so rel ease repl i cate groups of fi sh di rectl y into the bypass outfal I col I ecti on trap ( fl oating net pen) to al I ow us to eval uate inj ury caused by the collection and handli ng process (control).

We wi I conduct the test from mid-Apri I to I ate My when fi sh are avai l able (see Fi gure 3). Wh will repeat each test on three different dates for each species or race of test $f i s h$ and at $f l$ ous of 5 cf $s$ and 25 cf s. Each treatment and control, 5- cf s and 25- cf s rel ease wi I consi st of three 100-fish groups. For each species or race of test fish, total number of. rel ease groups will be 36 and total number of fish will be 3,600 ( 2 groups (treat nent t control ) $\times 2$ tests ( 5 cfs t 25 cf s) $\times 3$ repl i cates (dates) $\times 3$ groups per rel ease $x 100 \mathrm{fi}$ sh per group $=3,600$ fi sh; Table 1).

We will adhere to operation criteria for respecti ve bypass fl ow when performing the tests at a 5-cfs or 25-cfs bypass flow Thi s will i ncl ude the instal I ation of the restrictive orifice pl ate for 5-cfs fl ow and the concurrent operati on of the travel ing screen and pumpback pumps (USBR 1989). If bypass fl ow does not need to be ret urned to the canal, the river return drai $n$ pi pe gate shal I be open to ret urn water to the river. Wei $r$ gate positi ons for both fl ow regi nes wil al so be properly set according to operating criteria.

Wh will exam ne a $10 \%$ subsampl e from each treat ment and control repl i cate group for condi ti on pri or to rel ease to ascertai $n$ pre-rel ease condition. These subsampl e fi sh wil not be ret urned to thei $r$ groups. We will rel ease treatment $\mathrm{fi}$ sh at the nei $r$ crest in the upper bypass 
channel. We will rel ease control fish di rectly into the net pen from shore and then position the net pen under the bypass outfall (see Figure 4). We wi I rel ease control fish i medi atel y pri or to rel easing treatment fish. Therefore, both treat nent and control groups will be in the net pen at the sane ti ne. During the 25-cfs tests, we will instal I the bypass channel stopl og to reduce fl ous during control rel eases and subsequent net positioni ng. The stopl og will be renoved and a f ul I 25cf s fl ow will be achi eved pri or to rel easing the treatment groups.

To capt ure the maj ority of the test fish rel eased, the net pen wi I remai $n$ in position for at l east 30 minutes, or I onger, if necessary. We will retri eve the net pen after each group rel ease has been recapt ured. We will di $p$ net fish out fromthe net pen, pl ace them in contai ners and transfer them to the exami nation area. We will record rel ease and recovery infornation on a bypass outfal I test form

We wi I hol d recapt ured fi sh in smal I net pens in the river for i medi ate exami nati on al ong the shore. We wi I handl e fi sh and exami ne them for inj ury in the same manner as in the screen inj ury test. We will record data on a fish condition form

We will al I ow exami ned fish to ful I y recover from the anesthet ic in addi ti onal net pens $p l$ aced in the river; fish will be rel eased to the river after recovery. Fish in good condition will be retai ned for use i n secondary tests.

Drum Screen Leakage Test: To eval uate passage of $\mathbf{j}$ uveni I e sal moni ds through (I eakage) and over (i mpi ngenent) the dr um screens, we will rel ease test groups of fal I chi nook fry upstream of the screens and recapt ure them in fyke nets pl aced i medi at el y behi nd the screens in the VEI D Canal and in the bypass collection facility. We will al so rel ease groups of control fish i $n$ the fyke net nouth to obtai $n$ an esti mate of net col l ection and. retenti on ef fici ency. To obtai $n$ an esti mate on bypass col l ecti on ef $\mathrm{i}$ ci ency, we will rel ease groups of control fish in the bypass channel and recapt ure them in the sampl e tank at the collection facility. We will correct esti mates of the percent of fish rel eased above the screens and subsequentl y recapt ured in the fyke nets for sampling effici ency of the nets and the bypass collection facility. We will monitor fish passing over the screens during the test to segregate esti mates for screen passage and rol lover caused by i mpi ngement.

We will use fal I chi nook fry in the screen I eakage test. We wi I performtests as close to design. canal flow as possible on three different dates in early Apri 1 when fal I chi nook are in the fry stage (see Figure 3). Control fish will be differentiated from treatment fish with the use of a bi snark brown dye. Because of our i nability to desi gnate separate groups for each test rel ease, we will rel ease an enti re 300-fish treat ment group in front of the screens, and a 300-fi sh control group in the bypass channel for each test day. The 300-fish control rel ease in the nouth of the fyke nets wil be separated into 75fish group rel eases behi nd each of the four drum screens. Each of the 
three-day test rel eases wil be comprised of $900 \mathrm{fi}$ sh for a total of 2, 700 fry ( see Table 1).

We will place fyke nets behi nd the screens pri or to rel eases. To capt ure rel eased test fi sh in the collecti on facility, we will adhere to operation criteria for a sampling mode. Thi s incl udes the i nstallation of bypass channel sampl ing equi pnent, operati on of the travel ing screen, openi ng of the ri ver ret urn drai $n$ pi pe (pumpback pumps cannot be operated with fyke nets in pl ace), and proper setting of wei $r$ gate positi ons and headuorks uater I evel s (USBR 1989).

We wi I rel ease test fi sh di rectly i nto the canal headuorks upstream of the screens. We will rel ease dyed control fi sh behi nd each screen in the net mouth in separate 75-fish groups. We will use a PVC pi pe extended i nto the water to rel ease fi sh further down into the water col um. We will al so rel ease dyed control fish in the bypass channel (see Figure 4). We will make al I rel eases at approxi matel y the sane ti me. We will make succeeding test rel eases every 48 hours for a total of three test rel eases. The 48-hour i nterval is necessary to al l ow ti me for fi sh from one test repl i cate to cl ear the system bef ore rel ease of the next repl i cate, si nce separate test fi sh cannot be differentiated.

We will fi sh behi nd the screens for approxi matel y 48 hours after rel ease to capt ure control fi sh and any test fi sh that I eaked past or rolled over the screens. At 4-hour to 6-hour interval s during this 48hour period, we will exami ne the contents of the fyke net by i ndi vi dual I y rai si ng the nets, removing the contents of the cod end, and pl acing the contents in buckets. We will clean the nets with water suppl i ed from the travel ing screen spray water pump and i medi at el y I ower them back i nto pl ace. We will col l ect fry from the sampl ing tank in the bypass collection facility every hour. We will rel ease river run fi sh coll ected in the sampl ing tank back to the river.

We will al so set the fyke nets in position during the maj or migrati on peri ods of hatchery-rel eased and nat $i$ ve $f i$ sh to docunent any screen I eakage or i mpi ngenent of smolts. Thi s will occur at peri odic i nterval s from Apri I through J une.

We will record numbers of fry (treat ment and cont rol ) hourly from the sample tank and during each fyke net retrieval. During the tests, we wi I noni tor the drum screens for any i ndi cati on of fry i mpi ngement and document numbers of "roll over" fi sh. We will record I engths of al I treat ment fish that have passed through or over the screens and representati ve I engths of treat ment and control rel ease fi sh. Wh will record numbers and I engths of smol ts in the nets duri ng peak passage through the facility.

We will return fry and river-run fish retrieved from the nets and the sampling tank back to the river.

Travel ing Screen Leakage Test: To determi ne the exi stence and extent of fi sh I eakage through the travel ing screen bet ween the bypass channel and the pumpback bay, we will instal I a fyke net at the terninus 
of the 21-i nch di ameter ri ver return drai $n$ pi pe. The drai $n$ pi pe will be i $n$ operation during the sampling mode when the travel ing screen is functioni ng but the pumpback pumps are not. Al fish that pass through the operating travel ing screen will eventual Iy be di verted through the drai $n$ pi pe and recapt ured in the fyke net (see Fi gure 4).

Thi s test wil be perforned whenever it is necessary to operate the travel ing screen and open the ri ver return drai $n$ pi pe (operati on criteri a during a 5-cfs fl ow through the bypass channel when excess bypass fl ow can be ret urned to the river). We will conduct this test during the drumscreen I eakage test, the screen inj ury test, the bypass outfal I i nj ury test at 5-cfs, and the headgate inj ury test. When ri ver fl ow drops and bypass fl ow needs to be di verted back to the canal vi a the pumpback pumps, the drai $n$ pi pe will be cl osed.

We will peri odically i nspect fyke net contents by cl osi ng the pi pe to reduce out $I$ ow and extracting the contents from the cod end vi a a zi ppered openi ng.

Headgate I nj ury Test: To eval uate i nj ury and mortal i ty associ ated with passage through the headgates, we will rel ease groups of heal thy, freeze-branded fish upstream of the headgates, recapt ure them at the coll ecti on facility, and exam ne them for i nj ury or descal ing. We will use i nf or mati on obtai ned from the screen i nj ury tests to eval uate i nj ury caused by the collecti on and handling process.

We will adhere to normal canal operations and operating criteria for a sampling mode at the collection facility.

We will use ei ther river-run fish collected at the facility, fish used i n previ ous tests that are in good condi ti on, or extra unbranded test fish. We will freeze-brand unmarked fish with a uni que brand or use previ ously branded fish to differentiate them from river-run fish.

We will rel ease fish in separate groups in front of the headgates ( see Fi gure 4). Dependi ng on test $f i s h$ availability, we will rel ease three repl i cate groups of $\mathrm{fi}$ sh per day for three days at a specific headgate openi ng. Approxi matel y 50 to $100 \mathrm{fi}$ sh wi l compri se a group. We will make both day and ni ght rel eases to determine passage rates and potential for inj ury under the respective anbi ent I i ght condi ti ons. Tests will be perforned when possi ble in April and May.

We will recapt ure the fish in the bypass collection facility at hourl y i nterval s, and exami ne them for descal i ng and ot her i nj ury, foll owing the same procedure used in the screen inj ury test. We will record fish condition, and time of rel ease and recapt ure. After processing, we will rel ease the fish back to the river.

Descal ing Eval uation: We wi I determi ne fi sh condi ti on using descaling criteria devel oped by the U.S. Army Corps of Engi neers ( Nei tzel et al. 1985) for al I i nj ury tests. We will record exact observations of $f i s h$ i nj ury and scal e I oss, but for purposes of 
anal ysi s, we will event ual I y classify condition as percent heal thy, parti al I y descal ed or descal ed. We will base condition on the percentage of scal e I oss i n each of fi ve desi gnated secti ons per si de of fi sh and cl assify fi sh as "heal thy" ( scal e I oss $\leq 3 \%$ per secti on), "parti al I y descal ed" ( scal e I oss > 3\% but < $40 \%$ per secti on), or "descal ed" (cumul ati ve scal e I oss $\geq 40 \%$ i n any t wo secti ons). Cumul ati ve scal e I oss equal s the sum of the area of al I patterns of scal e l oss on one si de of a fish. We will record observations of other i nj ury types such as cuts, brui ses, eye or head i nj uri es, and torn opercul uns.

Test Fi sh: We will use yearling sumer steel head, yearling spring chi nook sal mon, subyearli ng fal I chi nook sal non, and fal l chi nook sal non fry in our eval uation. These speci es were sel ected because they are present in the Unatilla Ri ver system and because they occur at the desi red sizes to be tested. We will conduct al I injury tests using summer steel head and spring chi nook yearli ngs, and fal $\mathbf{l}$ chi nook subyearlings. We wil conduct the drum screen I eakage test with fal I chi nook fry.

Spring Chi nook: We wi I obtai $n$ approxi matel y 8,000 yearling spring chi nook sal non smol ts from the Carson Nati onal Fi sh Hatchery in Carson, Whshi ngt on. Fi sh will wei gh approxi natel y 18/I b and have an average I ength of $135 \mathrm{~mm}$ I $\mathrm{n}$ earl y Apri I, the ODFW Li berati on Program wi I transport the fish from the hatchery to the $M$ nthorn accl i mation facility operated by the Confederated Tribes of the Unatilla I ndi an Reservation. These fish will be hel $d$ at the pond until needed for the eval uati on.

Fal I Chi nook: We wi I l obt ai $n$ approxi matel y 2, 700 fal I chi nook sal mon fry from I rri gon Hatchery i $n$ I rrigon, Oregon, in earl y Apri I. Fi sh will wei gh approxi natel y 200/I b and have an average I ength of 35 $\mathrm{mm}$ We wi I obtai $n$ approxi natel y 8,000 subyearling fal I chi nook sal non snol ts from the I rrigon Hatchery in early My. Fi sh wi I wei gh approxi natel y 60/ 1b and have an average l ength of $90 \mathrm{~mm}$

Sumer Steel head: Wu i l obtai n 8,000 yearling sumer steel head snol ts (gradeouts) from Oak Spri ngs Hatchery in Mupi n, Oregon. Fi sh wi II wei gh approxi natel y $8 / \mathrm{I} \mathrm{b}$ and have an average I ength of $175 \mathrm{~mm}$ The ODFWLi berati on Program will transport the fish from the hatchery to CTUR' s M nthorn accli mati on facility in early April where they will be hel $d$ unt i needed for the eval uation.

Haul ing: We wi l haul the test fi sh from thei $r$ hol di ng I ocati ons approxi matel y four days pri or to the schedul ed test rel ease date. To transport the spring chi nook and sumer steel head from $M$ nthorn, and the f al I chi nook subyearl i ngs from I rrigon Hatchery, we wi I use ODFWs 370gal I on tanker equi pped with a ci rcul ati on and oxygen system To I oad the fish into the tankers, we wil need to croud and net the fish from 
the ponds at the respective hol ding sites. At the test site, we will unl oad the test fi sh into a large, net-I i ned recei vi ng tank suppl i ed with river water. We will position the tank in an accessible l ocation to easi I y unl oad the fi sh from the tanker (Fi gure 5).

We wi l haul fal I chi nook fry from I rrigon Hatchery to the test si te one day pri or to the test. We will use 32-gal I on contai ners aerated with bottled oxygen to transport the fry.

Harking: We devel oped a workabl e and suf $\mathrm{i}$ ci ent number of uni que brands usi ng a four rotati on and four positi on schene for each avai l able brand. We will mark each treatnent group with a uni que brand. We will use the right dorsal position for al l control fish, as control groups wi thi $n$ each repl i cate rel ease do not need to be differentiated (Table 2).

We wi I l begi $n$ freeze- brandi ng repl i cate treat ment and cont rol groups the day after fish have been haul ed to the test site. Brandi ng of 3,600 fish will take from 1 to 2 days. After brandi ng, we will hol d fi sh in separate contai ners for 48 hours to 72 hours to al I ow the brand to set and the fi sh to accli mate. We will record branding inf or nati on on a branding form

We will dye the control groups of fal I chi nook fry for the screen l eakage test with bi smark. broun dye to differenti ate them from the test group. Fi sh will be $\mathrm{pl}$ aced i $n$ an aerated contai ner with the dye mixt ure for one hour to al I ow ti me for the dye to set.

Hol di ng and Whter Suppl y System We wi I hol d al I 36 separate groups for the i nj ury tests i n appropri ate-si zed contai ners. These contai ners will be specifical Iy l abel ed with the brand mark, fi sh speci es and number. The contai ners will be i $n$ I arge tanks suppl i ed with pumped river water from the canal, will be perforated to al I ow fl ow through of water, and covered with netting to prevent fish escape but permit sunlight penetration. We will record nortalities, temperat ure, and other observations during peri odi c checks.

Two el ectric subnersi bl e pumps will be used to pump water from the VEI D Canal i nto the I arge hol di ng tanks through a regul ated mani fold system of PVC pi pes and val ves (Fi gure 5). Each sump pump will have a naxi mum pumpi ng capaci ty of 170 gal l ons per mute (gpm) at a 10-ft head whi ch wi I suppl y approxi matel y $55 \mathrm{gpm}$ of i nf I ow water to each of the 6 I arge tanks. A gas centrifugal pump wil be avai l able in case of submersible pump fail ure. Pumped nater will ci rcul ate around the tank, provi di ng i nf I ow to the hol di ng contai ners, and drai $n$ out a stand pi pe back i nto the canal. Standpi pe I ength wil regul ate water depth.

We will use the auxillary i nflow water supply at the bypass col l ection facility for hol di ng fish in contai ners in this area. from the traveling screen spray water pump will al so be used for Whter mi scel I aneous operati ons ( Fi gure 5). We will use fl oati ng net pens to hol d fish in the canal headworks area or in the river, if necessary. 


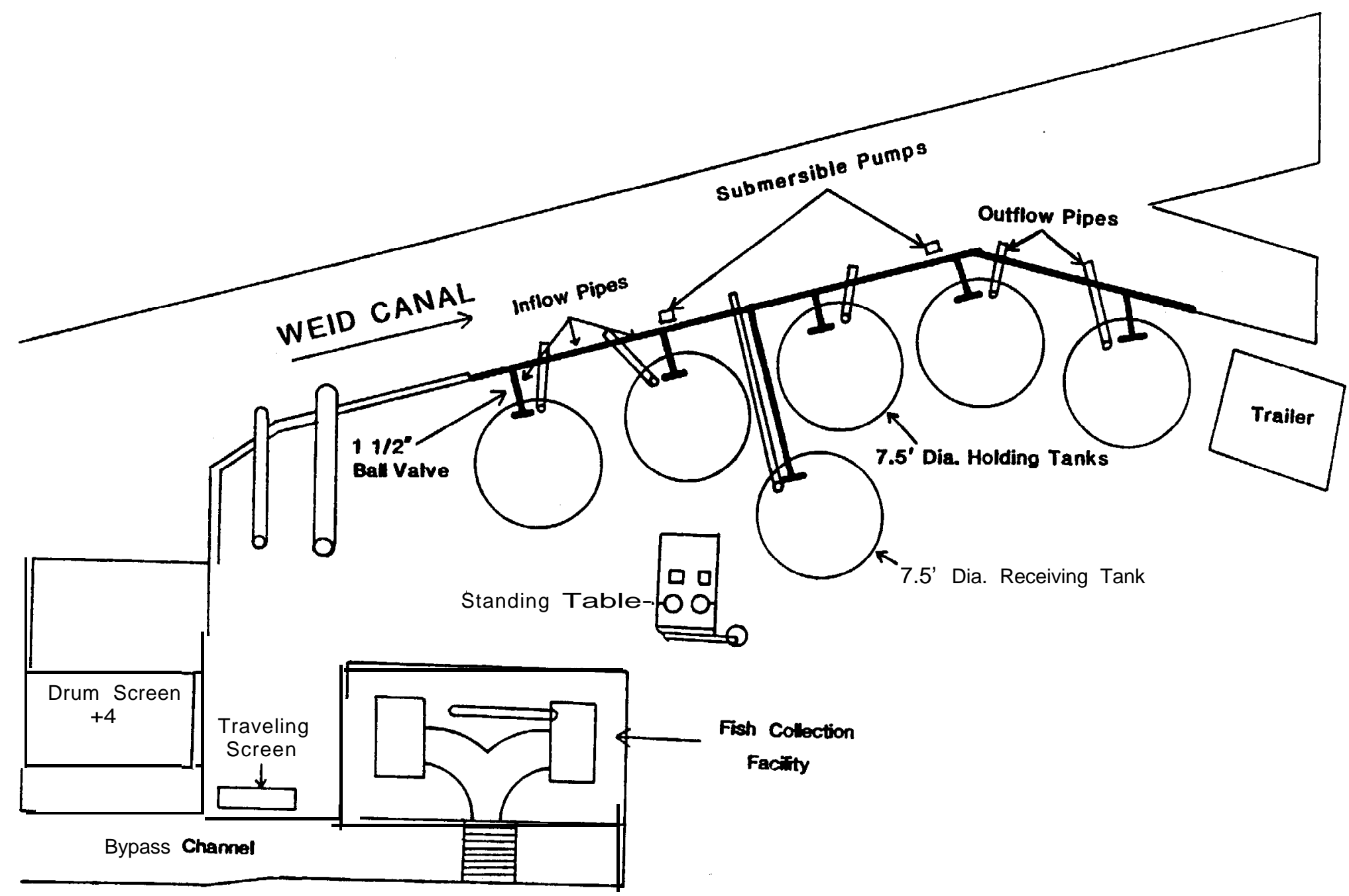

Fi gure 5. Schematic of fish hol ding facilities and test set-up at the VEID Canal facility, Three Mle Falls Dam Spring 1991. 
Table 2. Patterns and l ocations of freeze-brands used on fi sh rel eased at the $\mathbf{j}$ uvenile fi sh bypass facility in the West Extensi on I rrigation Di stri ct Canal, Three M I e Fal Is Dam Spring 1991.

\begin{tabular}{|c|c|c|c|c|c|c|c|}
\hline \multirow[b]{2}{*}{ Brand } & \multirow[b]{2}{*}{$\begin{array}{l}\text { Test, } \\
\text { repl i cates }\end{array}$} & \multicolumn{2}{|c|}{ Tr eat ment } & \multicolumn{4}{|c|}{ Cont rol } \\
\hline & & $\begin{array}{l}\text { Grou } \\
\text { posi }\end{array}$ & $\begin{array}{l}\text { or and } \\
\text { in }\end{array}$ & & $\begin{array}{l}\text { Grou } \\
\text { posi }\end{array}$ & r and & \\
\hline $\begin{array}{l}E \\
\mathbb{N} \\
\mathbb{4}\end{array}$ & $\begin{array}{l}\text { Screen I nj ury Day: } \\
\quad 1 \\
2 \\
3\end{array}$ & $\begin{array}{l}1 \\
\text { LA } \\
\text { LA } \\
\text { LA }\end{array}$ & $\begin{array}{l}2 \\
\text { RA } \\
\text { RA } \\
\text { RA }\end{array}$ & $\begin{array}{l}3 \\
\text { LD } \\
\text { LD } \\
\text { LD }\end{array}$ & $\begin{array}{l}1 \\
R D \\
R D \\
R D\end{array}$ & $\begin{array}{l}2 \\
R D \\
R D \\
R D\end{array}$ & $\begin{array}{l}3 \\
R D \\
R D \\
\text { RD }\end{array}$ \\
\hline$\underset{\xi}{\xi}$ & $\begin{array}{l}\text { Screen I nj ury } \mathbf{N} \text { ght: } \\
\quad 1 \\
2 \\
3\end{array}$ & $\begin{array}{l}\text { LA } \\
\text { LA } \\
\text { LA }\end{array}$ & $\begin{array}{l}\text { RA } \\
\text { RA } \\
\text { RA }\end{array}$ & $\begin{array}{l}\text { LD } \\
\text { LD } \\
\text { LD }\end{array}$ & $\begin{array}{l}\text { RD } \\
\text { RD } \\
\text { RO }\end{array}$ & $\begin{array}{l}\text { RD } \\
\text { RD } \\
\text { RD }\end{array}$ & $\begin{array}{l}\text { RD } \\
\text { RD } \\
\text { RD }\end{array}$ \\
\hline $\begin{array}{l}\pi \\
\pi \\
\pi\end{array}$ & $\begin{array}{l}\text { Bypass I nj ury } 25 \text { cfs: } \\
\quad 1 \\
2 \\
3\end{array}$ & $\begin{array}{l}\text { LA } \\
\text { LA } \\
\text { LA }\end{array}$ & $\begin{array}{l}\text { RA } \\
\text { RA } \\
\text { RA }\end{array}$ & $\begin{array}{l}\text { LD } \\
\text { LD } \\
\text { LD }\end{array}$ & $\begin{array}{l}\mathrm{RD} \\
\mathrm{RD} \\
\mathrm{RD}\end{array}$ & $\begin{array}{l}\text { RD } \\
\text { RD } \\
\text { RD }\end{array}$ & $\begin{array}{l}\text { RD } \\
\text { RD } \\
\text { RD }\end{array}$ \\
\hline (2) & $\begin{array}{l}\text { Bypass I nj ury } 5 \text { cfs: } \\
\quad \\
2 \\
3\end{array}$ & $\begin{array}{l}\text { LA } \\
\text { LA } \\
\text { LA }\end{array}$ & $\begin{array}{l}\text { RA } \\
\text { RA } \\
\text { RA }\end{array}$ & $\begin{array}{l}\text { LD } \\
\text { LD } \\
\text { LD }\end{array}$ & $\begin{array}{l}\text { RD } \\
\text { RD } \\
\text { RD }\end{array}$ & $\begin{array}{l}\text { RD } \\
\text { RD } \\
\text { RD }\end{array}$ & $\begin{array}{l}\text { RD } \\
\text { RD } \\
\text { RD }\end{array}$ \\
\hline
\end{tabular}

LA=Left Anteri or, RA=Right Anteri or, LD- Left Dorsal, RD-Right Dorsal 


\section{Data Anal ysi s:}

I nj ury Esti nates: We wi II compute nean and $95 \%$ conf $\mathrm{i}$ dence interval $s$ for the proporti on of juvenile spring and fall chi nook sal mon and sumer steel head that are descal ed (and ki Il ed), parti al l y descal ed (and injured) or that renai $n$ heal thy during passage past the screens (screen i njury treatment) and passing from the collection facilities to the outfal I (bypass pi pe and outfal I i nj ury treat ment). We will al so compute mean and $95 \%$ conf $i$ dence $i$ nterval s for the proporti on of $j$ uveni I e sal non that are descal ed, i nj ured, parti al l y descal ed or are heal thy i n the corresponding control groups for each test. We will use anal ysis of vari ance (ANOVA) to test for si gni fi cant di fference $(P<0.10)$ bet ween the respective treatment and control groups. We will transform the data as appropri ate to meet the assumptions of ANOVA

Rel ati ve fi sh conditi on wi I be determined by di vi di ng the nunber of descal ed, partially descaled or heal thy fish in a sample by the total number sampl ed and mil ti pl yi ng by 100.

We will esti mate the $95 \%$ confidence interval for descal ed, parti al I y descal ed or heal thy fi sh from " $x$ " number of repl $i$ cates for each speci es as

$$
\tilde{\mathbf{n}} \pm t s / \sqrt{N}
$$

where

$$
\begin{aligned}
& \tilde{\mathbf{n}}=\text { mean percent of } \mathrm{f} i \mathrm{sh} \text { descal ed, parti al l y descal ed or } \\
& \text { heal thy from } x \text { number of repl } i \text { cates } \\
& t \text { = student' } s \text { t di stributi on val ue at } x \\
& \text { degrees of freedom and } \alpha=0.05 \text {. } \\
& \text { S = sampl e st andar } d-\text { devi at } i \text { on } \\
& \mathrm{N} \text { = number of repl i cates }
\end{aligned}
$$

Screen Effici ency Esti mates: We will test the nul I hypothesi s that no $f i$ sh pass the drum screens and enter the i rrigation canal and al $I$ fish that encounter the drum screens are gui ded i nto the bypass. We will esti nate screen ef $\mathrm{f} i \mathrm{ci}$ ency for each test and overal I.

We will correct esti mates of screen ef $\mathrm{fici}$ ency for sampl i ng effi ci ency. The sampl ing ef $f i$ ci enci es comput ed to esti mate screen effici ency will be: bypass col lecti on ef $f i c i$ ency $\left(E F F_{b c}\right.$ ) and net capt ure efficiency $\left(E F F_{n c}\right)$. We will assume net retention to be equal to net efficiency, gi ving it a val ue of 1 . The formul a for esti nating screen efficiency $\left(E_{\text {SC }}\right)$ will be

$$
E_{\text {SC }}=1 \cdot \frac{\text { Xnet }}{E F F_{n c^{N}}}
$$


where

$x_{\text {net }}=$ number of $\mathrm{fi}$ sh rel eased upstream of the screens and caught in the nets, and

$\mathrm{N}=$ an esti mate of the total number of fish encountering the screens.

$$
\begin{gathered}
N=X_{\text {net }}+X_{b c} \\
E F F_{n c} \\
E F F_{b c}
\end{gathered}
$$

where

$x_{b c}=t$ the number of $f i$ sh rel eased upstream of the screens and caught in the bypass col lection facility.

$$
\begin{aligned}
& E F F_{n c}=\frac{n_{n c}}{N h c} \\
& E F F_{b c}=\frac{n b c}{N b c}
\end{aligned}
$$

where

$$
\begin{aligned}
& \begin{array}{l}
n_{n c}=\begin{array}{l}
\text { the number rel eased i } n \text { the net mouth and caught in the } \\
\text { net, }
\end{array}
\end{array} \\
& \text { Nhc = the number rel eased i } n \text { the net nout } h \text {, } \\
& \mathrm{nbc}=\text { the number of } \mathrm{fi} \text { sh rel eased i } \mathrm{n} \text { the bypass channel and } \\
& \text { caught in the bypass collection facility, and } \\
& \mathrm{Nbc}=\text { the number rel eased in the bypass channel. }
\end{aligned}
$$

We will compute an overal I effi ci ency esti nate by conbi ni ng al I data from the vari ous tests. In thi s way, the varying $\mathbf{N}$ val ues wi I be i ncorporated and differences in test si ze will be compensated.

Trave7 Ti me Esti mates: We will determine test fish travel ti ne from the headgates to the bypass collection facility by esti mating the ti me to recapt ure $50 \%$ (nedi an travel ti me) and $95 \%$ of the rel eased test fish. We will esti mate travel ti me through the I ower bypass by determining recapt ure rates for rel eased test fi sh at a 5-cfs and 25-cfs bypass fl ow 
Preparatory Activities

Hol di ng: We cal cul at ed requi red hol di ng contai ner capacity for the vari ous sizes of test fish using a 2 pound per cubic foot formula. Based on thi s capacity, the number of $f i$ sh per pound, and the number needed for a test, we determined the anount of contai ners requi red. For the small er test fi sh, we acqui red 36 6-gal I on buckets. We drill ed 1/4i nch hol es in the upper porti on of the pai I s to al I ow water to fl ow through. We fabricated mesh covers and straps to hol d the covers in pl ace. We tested the degree of uater exchange with a dye to assure sufficient infl ow and water exchange.

We acqui red 72 20-gal I on contai ners for the I arger $f i$ sh and si milarly perforated the upper portion with hol es. We al so cut out horizontal sl ots and covered these with mesh. These contai ners vere al so tested.for ci rcul ation using a dye. We cut out the center portion of the Iid and covered the openi ng with mesh to al l ow sunl ight penet ration.

W tested the stabi lity of the contai ners i $n$ water and di scovered that wei ght s woul d be needed to el i mi nate buovancv. We acqui red l ead wei ghts,-and affixed wi re hooks to secure the- wei ghts on the contai ner handl es.

We used 5 I arge 800-gal I on pl asti c tanks, $7.5 \mathrm{ft}$ i $\mathrm{n}$ di ameter, to hol $d$ the needed number of 6-gal I on and 20-gal I on contai ners. These were ol d fertilizer tanks that we cut in half and repai red, usi ng the bottom 3-ft deep porti on. A si xth tank was cut I ower to accommodate unl oadi ng of fi sh from the tanker. we determined the number of contai ners that each tank would hol d, and di vi ded thi s number into the total number of contai ners to determi ne the requi red number of tanks.

We neasured avai I able space at the si te to desi gn a workabl e I ayout for the hol ding system he pl umbed the water infl ow and outfl ow systens, set in the pumps, and tested the system ( see Fi gure 5).

We desi gned smal $\mathrm{I}$ and I arge net pens for use in the canal or ri ver. We contacted a vendor to fabri cate the mesh cages, and fabri cated the frames oursel ves. The $10 \mathrm{small}$ net pens were 18 inches square and 18 i nches deep. The one I arge net pen was 4, ft $\times 4 \mathrm{ft} \times 2 \mathrm{ft}$. deep (Fi gure 6). Net pens were made from 3/16-i nch knotless nyl on netting and contai ned a zi pper in the top mesh for access. Frames were constructed of I-i nch PVC pi pe and nets were attached with plastic cable ti es.

Branding and Harking: We constructed a branding table for use at the si te which i ncl uded a si de trough for transferring fish to a hol di ng contai ner. We acqui red the necessary brandi ng equi pment, tool s, and suppl $i$ es and arranged to have the I i qui d ni trogen stored at the I rrigon Hatchery. We observed branding operations at the hatchery to becone familiar with branding techni ques.

We consulted with other bi ol ogi sts to determine a nethod for dyeing fal I chi nook fry and deci ded to use Bi smark Brown $Y$ dye. Before usi ng 

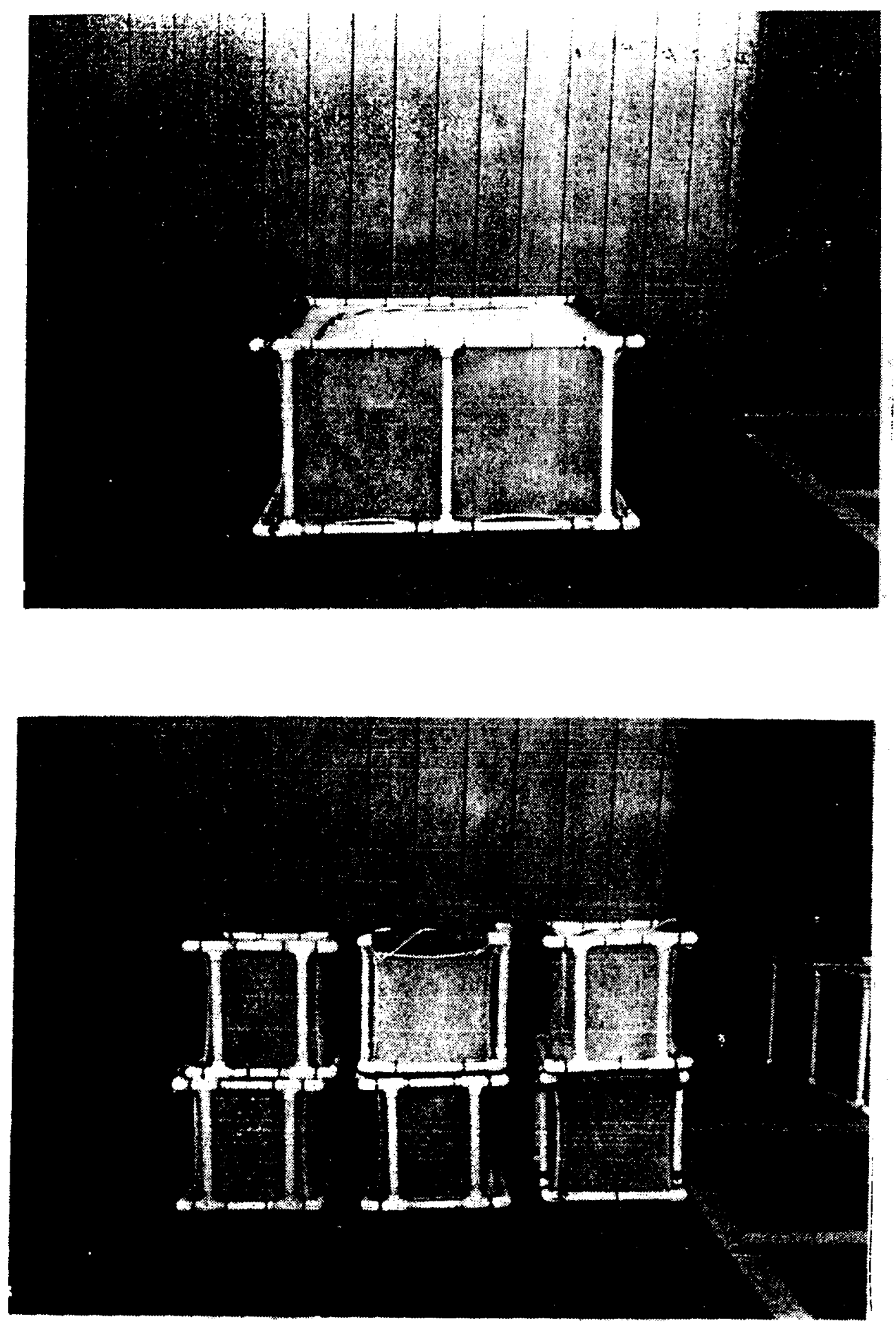

Fi gure 6. Large (upper) and smal I (I ower) net pens for use i n VEI D Canal facility eval uati on acti viti es, Three M I e Fal Is Dam Spring 1991. 
the dye for the eval uation, we tested the dye with fry to determine proper procedures and concentrations.

Trap Desi gn: We desi gned fyke nets for the screen I eakage test to fit i $n$ the stopl og gui des behi nd each drum screen and conf orm to the avai I abl e space and di recti onal current (Figure 7). We contacted vendors for fabrication of the nets and the fyke net frames. Net di nensi ons i ncl uded a mouth openi ng of $7.25 \mathrm{ft}$ I ong by $12 \mathrm{ft}$ wi de tapering to a 1-ft square cod end $1.5 \mathrm{ft}$ in depth. Net lengths varied depending on thei $r$ respecti ve drum screen positi on. A zi pper uas i nstal led in the cod end to access contents and an al um num square frame was i ncorporated at the net-cod end transi ti on to add support. The nets were fabri cated of I/ 8-i nch del ta knotless nyl on mesh with openi ng edges encased i n 8- oz nyl on. One-quarter i nch gromets were appl i ed around the edgi ng, spaced 6 i nches apart.

Fyke net franes neasured $12.7 \mathrm{ft}$ wi de by $8 \mathrm{ft}$ I ong and were constructed of 3-i nch by 3 - i nch steel angl e i ron (Figure 8). The 8- $\mathrm{ft}$ I ength of the franes al l owed for a 0.5-ft cl earance above the normal operati ng water I evel in the VEI D Canal. Li fti ng brackets were wel ded onto the top edge of the frame. Additional 1.5-i nch by 1.5-i nch steel angle i ron pi eces were. wel ded to the i nsi de edge of the frane and drilled with I/4-inch hol es spaced 6 inches apart. Fyke nets were bolted onto this i nner frame. Four Z-i nch by I o-i nch boards were bolted i nsi de each mai $n$ frane to make a sol id panel wi th a one-foot gap at the bottom to fl ush out silt. To assi st i n net depl oyment and retrieval wi th the gantry crane, we requested nodified cable slings from the Bureau of Recl anation.

We desi gned a fyke net for the river return drai $n$ pi pe to eval uate fi sh I eakage through the travel ing screen (Fi gure 9). The fyke net openi ng was $2 \mathrm{ft} \times 2.5 \mathrm{ft}$, and encased in 8-0z nyl on. The net was fabri cated from / 8-i nch del ta knotless nyl on netting. A zi pper was i ncl uded in the cod end for content removal. The 2.3-ft by 2.8- ft net f rane was constructed of 2 - i nch $x$ 2-i nch angl e i ron. The net was bol ted to the frane through drilled hol es, spaced 6 i nches apart. To instal I the net and frame, we secured angle i ron brackets to the concrete retai ni ng ual I on each si de of the pi pe opening. This requi red pumping out the water from the drai $n$ pool to I over the water l evel.

Equi pnent Needs: We purchased suppli es for al l aspects of the eval uati on after accessing what our sampling and saf ety needs were for each specific activity.

We acqui red addi ti onal vehicl es for transportati on needs to and from the site for all shift rotations. We borrowed a trailer from the U. S. Fi sh and Vild i fe Servi ce to use for of i ce space and gear storage at the test site.

We assi sted CTU $R$ i $n$ constructing a crouder and di vi der for the Mnthorn accl i mati on pond where our test fish were to be hel d. The crouder was to be used during the I oading process. 


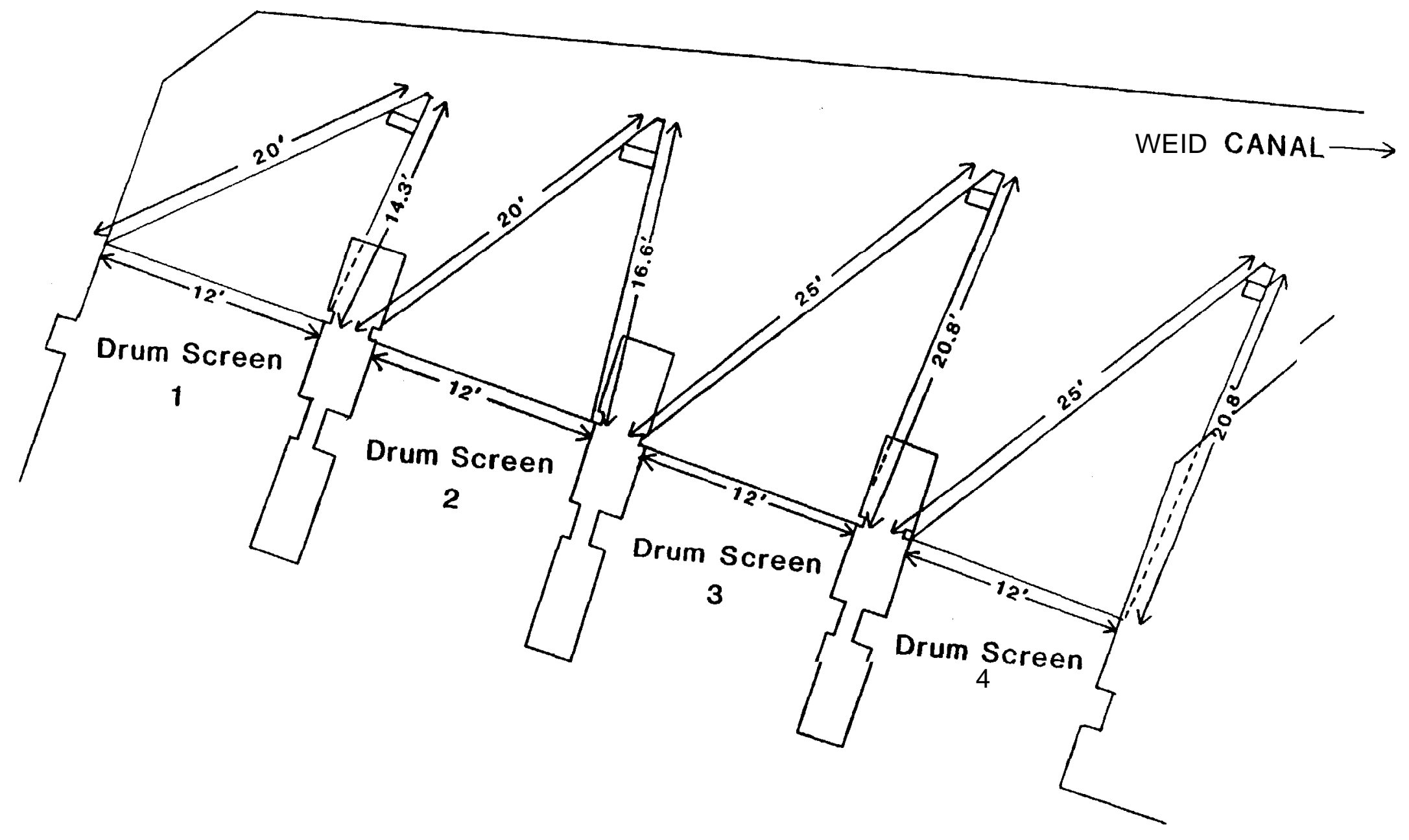

Fi gure 7. Drumscreen fyke nets for screen l eakage test at the VEI D Canal facility, Three Mle Falls Dam Spring 1991. 


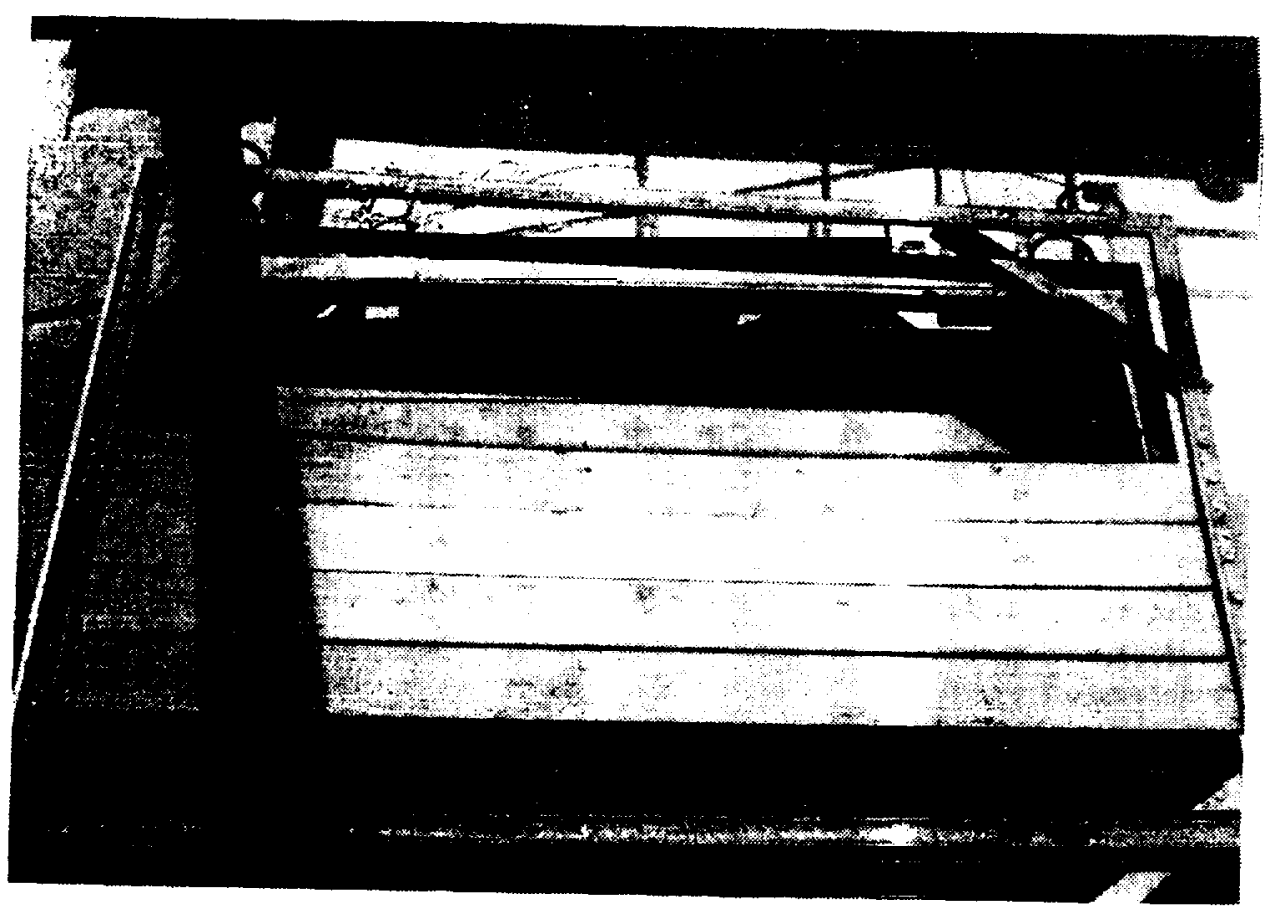

Fi gure 8. Fyke net franes for screen leakage test at the WEI D Canal facility, Three MIe Fal Is Dam Spring 1991. 


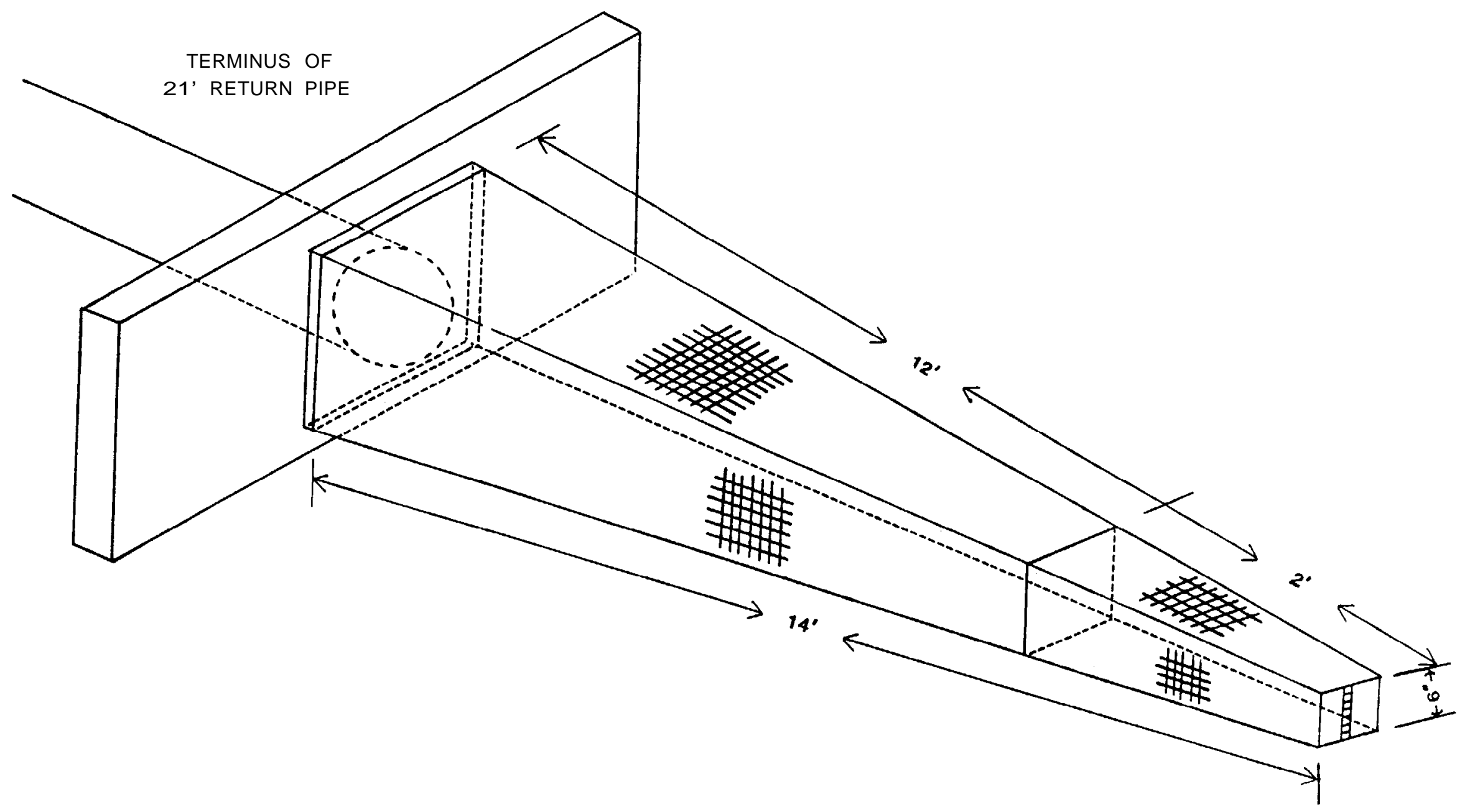

Fi gure 9. Fyke net for travel ing screen l eakage test at the WEI D Canal facility, Three Mle Fal Is Dam Spring 1991. 
Facility and Gear Modifications: Modi fications to the facility i ncl uded the i nstal I ati on of addi tional I i ghting at the si te to enhance ni ght $t i$ me eval uati on acti vi ti es and i mprove safety. We were assi sted by the Bureau of Recl anati on in i nstal I ing quartz I amps on the gantry crane and near the hol di ng tanks. We al so devel oped a portabl e I i ght ing syst em to faci I i tate ni ghtti ne rel eases i $n$ non- i I umi nat ed areas.

Upon request, the Bureau of Recl amati on modi fied an exi sting el ectrical outl et on the not or control center to accomodate the vol tage of our tno subnersi ble pumps.

At the collection facility, we nodified the sampling tank by el i mi nating gaps around the cover to prevent fi sh escape. We instal led hose spl itters and hoses for hol di ng fish in auxill ary contai ners. We fabricated a slide gate for the fish separator to prevent fish from entering the transfer fl une during sample tank croudi ng.

We modified the I arge fl oating net pen to be used in the bypass outfal I test by repl aci ng deteri orated pl astic cable ti es with hose cl amps to more securel y hol $d$ the net to the frane, and appl $i$ ed enanel paint to the frame for sun protection. After testing the net pen in a 25-cfs outfl ow we real ized the need for wi nches to facilitate depl oyment and securenent of the net. We i nstal I ed t uo smal I wi nches on hand railings above and adj acent to the bypass outf al I. We I abel ed net pen ropes to facilitate proper connections and positioning.

I $\mathrm{n}$ the bypass outfal I pl unge pool, we removed I arge boul ders, wood and $\mathrm{m}$ scel $\mathrm{I}$ aneous debri s to reduce potent $\mathrm{i}$ al danage to the net pen during use. We marked 1-ft i ncrenents on the adj acent concrete wall as a modified staff gauge to determine pl unge pool depth. We al so cl eared the shorel i ne of debris and brush to i mprove access during our tests.

Personnel: We hi red 5 addi ti onal seasonal personnel i n Iate March to assi st in the eval uation activities, for a total of 7 staff members. Thi s al l owed us to conduct the eval uati on on a 24-hour basi s, 7 days-aneek.

Upri ver Acti vi ti es at Maxuel I and Westl and Di versi on Dans

Trap Desi gn

We used an i ncl i ned pl ane trap desi gn for the bypass trap at Maxuel I Dam(Figure 10). Our desi gn was patterned after the type used by Battel le, Paci fi c Northwest Laboratori es in thei $r$ eval uations of $f i s h$ screening facilities in the Yaki ma River Basin. The i ncl i ned pl ane was $3.8 \mathrm{ft}$ wi de by $4 \mathrm{ft}$ I ong with 2.5-ft hi gh si dewal Is servi ng as spl ash guards. A 1. 3-ft wi de by 2.5-ft I ong by I-ft deep I i ve box (24. 3 gal. capaci ty) was wel ded to the downstream end of the trap. We desi gned a pi vot-rod front entrance assenbly to permit leverage capabilities in adj usting the fl ow of water reaching the I i ve box. The trap frame was sol i d 3/ 16-i nch al umi num sheet ing supported on secti ons of I-i nch by I- 

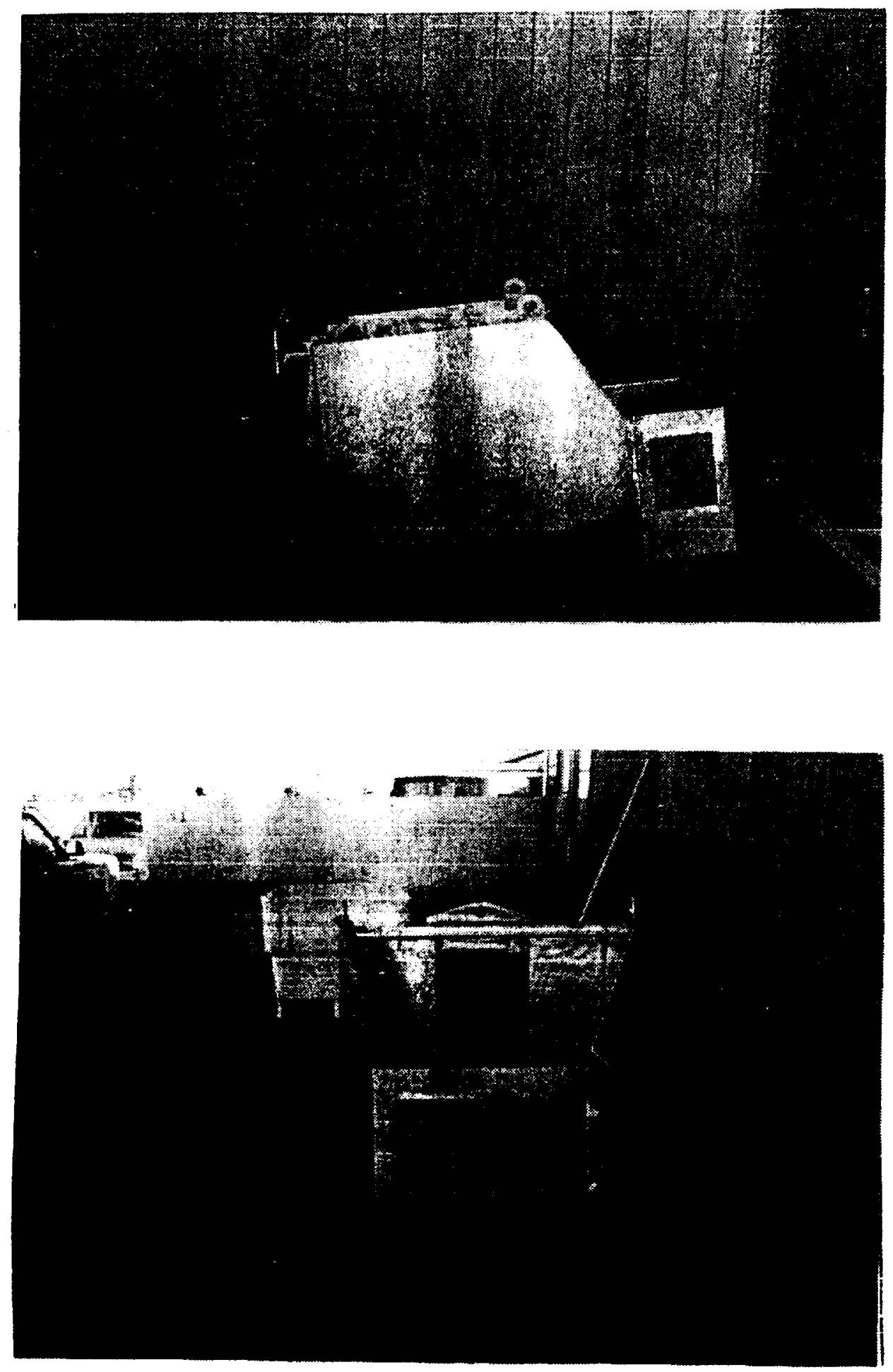

Fi gure 10. I ncl i ned pl ane fi sh trap, Maxuel I Dam fi sh bypass channel, Spring 1991. 
i nch angl e i ron wel ded to 2-i nch al um num strap cross pi eces.

Perforated sheeti ng contai ni ng I/ 8-i nch di aneter, staggered hol es (40\% open) was used for the fI oor of the trap and I i ned the I i ve box wal Is for el i mating excess water. Lifting brackets were wel ded into the si de wal Is and a I ifting eye was i ncorporated into the front entrance assembl y for rai si ng and I oweri ng the trap with hoi sts. The surface area of the perforated $\mathrm{pl}$ ate uas desi gned to el i mate a I 0 cfs bypass fl ow

We desi gned a fyke net and fl oating I i ve box assenbl y for use i n the $\mathrm{j}$ uveni l e fi sh hol di ng pond at the Westl and Damfi sh facility (Fi gure 11). The 12.3-ft I ong fyke net neasured $4 \mathrm{ft}$ by $3.6 \mathrm{ft}$ at the entrance and tapered to a coni cal ' I-i nch di aneter end which was attached to a I i ve box. Three al umi num ri ngs were i ncorporated al ong the tapering portion of the net to hold its shape. The front edge of the fyke net was encased in 8- oz nyl on with gromets appl i ed. The 1.5-ft by 3-ft by 2- $f t$ I i ve box was supported on a frane of I-i nch PVC pi pe encased i $n$ foam pi pe insul ation for fl ot ation. The bottom porti on of the frame was perf or at ed to al I ow water i nf I ow f or added wei ght and stabi I i zati on. The ent i re fyke net and I i ve box assenbly was fabricated of I/8-i nch del ta knotless nyl on netting. The fyke net frane was constructed of 2i nch by 4-i nch I unber fast ened together with netal brackets, and measured 4. $17 \mathrm{ft}$ wi de by $5.25 \mathrm{ft}$ l ong. Tho 3/8-i nch eye bol ts secured to the top edge of the frame al l owed for depl oynent and retri eval.

\section{Other Activities}

We i nspected the wast ewater overfl ow channel at Maxwel I Dam We found the di rt channel to be occl uded with debris at the entrance (Fi gure 12). The renai nder of the channel was cl ear and rocky, and empti ed i nto a smal I pool l eadi ng to the river. We consi dered the rel ati vel y I ow gradi ent to be conduci ve to fi sh strandi ng during abat enent of overfl ow peri ods.

\section{SCUSSI ON}

We encountered rel ati vel y few maj or problens in our efforts to neet study obj ectives. Noteworthy concerns or chal lenges that di ari se are presented in this di scussion.

I n our i nitial coordi nation with the ODFWi berati on Program to haul test fish from the hatcheries to the temporary hol ding site at M nthorn, our test $f i$ sh were to be haul ed i $n$ conj uncti on with schedul ed I i berations. However, concerns arose on how our eval uati on fish were to be segregated from the renai nder of the I oad. If haul ed in the I arge tanker, test fi sh could not be transported or unl oaded separatel y from the mai $n$ l oad of fish. This si tuation requi red that an extra tanker be used and extra trips made to specifical ly haul our test fish.

A though we had requested unmarked fish for use in the test and nere assured al I fi sh were unmarked, we I ater di scovered that $25 \%$ of the spring chi nook from the Carson National Fi sh Hatchery were AD+CWT. Thi s 

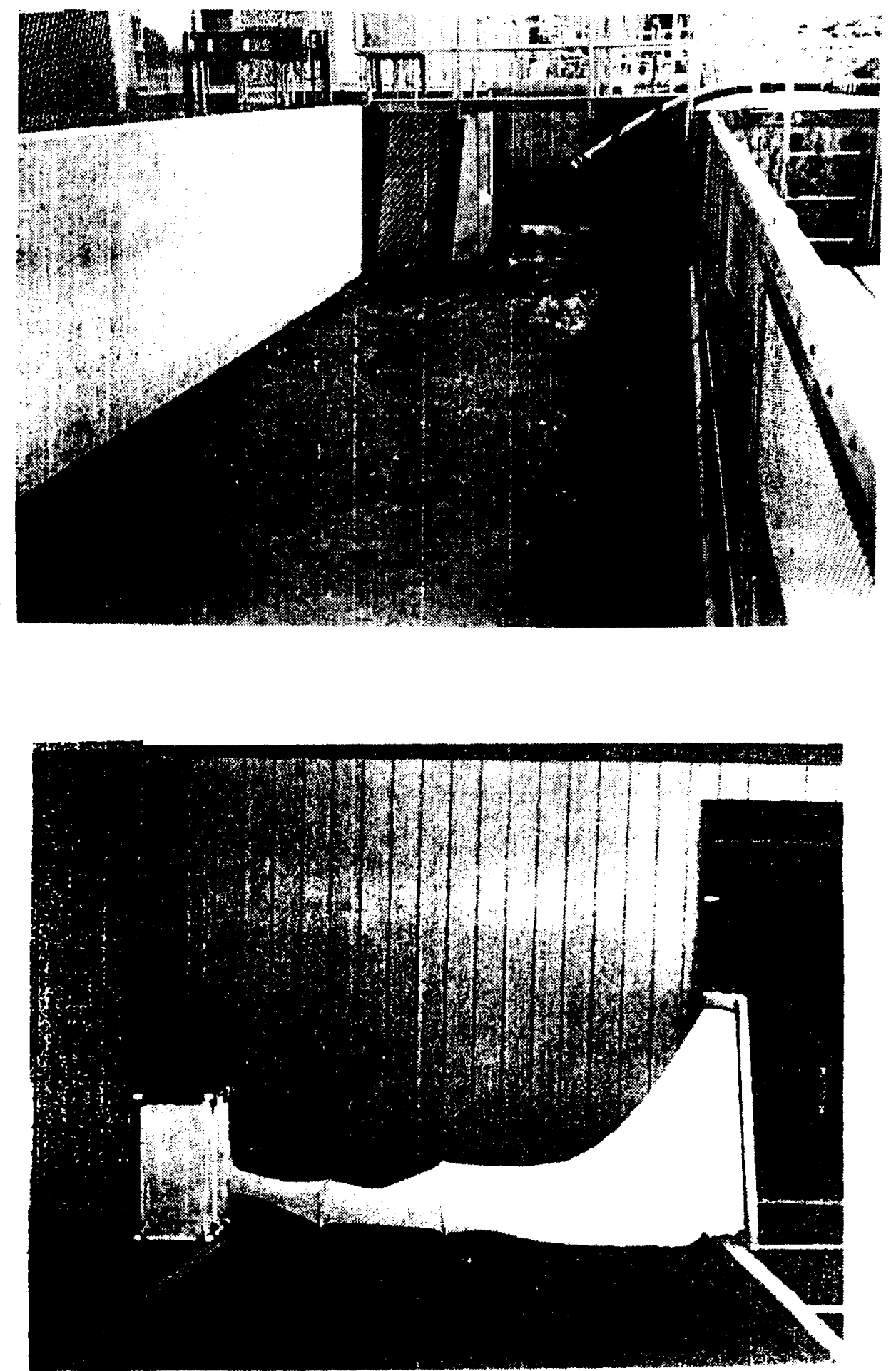

Fi gure 11. West I and Dam j uveni I e fi sh hol di ng pond (upper) and fi sh coll ecti on fyke net (l ower), Spring 1991. 


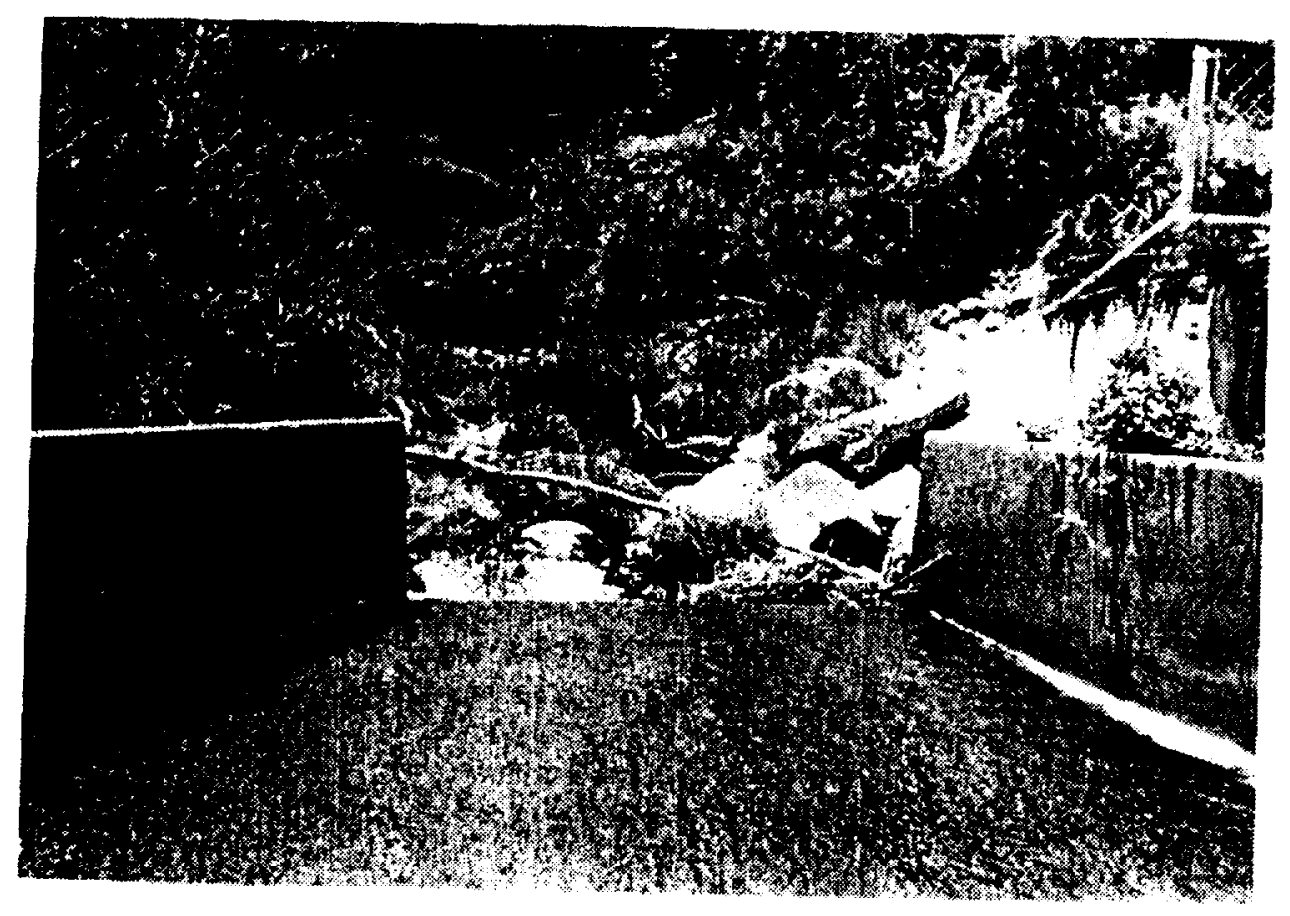

Fi gure 12. Entrance to wast ewater overf I ow channel at Maxuel I Dam canal, Spring 1991 
di scovery requi red addi ti onal i nvesti gati on to determi ne the reason for the mark and determine whether our use of these fish nould affect any noni tori ng or eval uati on study.

Our patterni ng of the basi c fyke net frame desi gn after frames i nstal led by the Bureau of Recl amati on to hel $p$ fl ush out si It behi nd the drum screens had a glitch. Apparently, I ifting brackets on the Bureau frames were not properly desi gned for the gantry crane at the VEI D facility (i.e. they were positioned too far apart). Thus, our Iifting brackets were in error al so. We renedi ed thi s probl em by desi gning a new cable sling to Iift the franes.

During assenbly of the fyke nets to the frames, we di scovered that the spaci ng of the gromet hol es in the net edging di d not preci sel y match the bolt hol es in the frane. Thi s error was caused by the pl acenent of bol t hol es cl ose to the frane corners whi ch was not accounted for in the spacing of net gromet hol es. To fasten the nets adequatel y to the frames, we ei ther had to drill new hol es in the franes or punch in new gromets in the net edging.

Our prol onged ef forts in desi gni ng the vari ous $f$ yke nets needed $f$ or the eval uati on at Three MIe Fal Is Dam resul ted i $n$ a reduced anount of avai lable ti me for fabrication. We did not recei ve fyke nets for the screen I eakage test until one day bef ore the schedul ed start of the test. Thi s created a two-day del ay in i ni ti ating the test to al l ow ti me for assenbly. We al so recei ved the drai $n$ pi pe fyke net I ater than ant i ci pated, which del ayed our ability to test for travel ing screen l eakage.

After acqui ring the submersi ble pumps for provi ding infl ow water during the eval uation, we di scovered that an exi sting 240-vol t out let on the not or control center at the VEI $D$ facility needed to be modified to accommodate the two 230-volt submersible pumps. To rectify this si tuati on requi red addi $t i$ onal eff ort from Bur eau personnel .

We ori gi nal Iy thought staffing needs for the eval uati on woul d be satisfied with 4 research personnel. However, in the preparation process, it became apparent that extra personnel noul d be needed; a total of 7 empl oyees were needed to cover the operati on 24 hours-a-day, 7 days-a- week. Three of these empl oyees were hi red i medi at el y pri or to the eval uation.

Our i ni ti al pl ans for desi gni ng bypass traps di d not i ncl ude the Westl and facility due to the thought that we could use the $\mathrm{j}$ uveni le fi sh hol di ng pond as a collection system However, it becane apparent that we needed to desi gn a nore effecti ve and ef $\mathrm{f} i \mathrm{ci}$ ent sampl ing system due to i ntri nsi c i nadequaci es of the hol ding pond. Our concerns uere f urther compounded when we di scovered that it nould be very difficult to pl ace a trap in the bypass channel due to the shall owness of the downuel $I$ and the absence of a structure to secure or nount the trap. Therefore, we needed to devi se a system for col lecting fish as they entered i nto the hol di ng pond for use in fut ure screen i nj ury tests. Thi s part of the eval uati on wil l be I i mited to I ow ri ver fl ow peri ods when $\mathrm{fi}$ sh are bei ng col l ected i $\mathrm{n}$ the hol di ng pond. 
Our ability to eval uate the Westl and facility at maxi mum desi gn fl ow nay be constrai ned due to bypass operational restrictions at hi gh and I ow river flous. The design constraint at this facility uas due to a I ow gradi ent in el evation fromthe facility to the river. During high ri ver fl ous, ri ver water wi I back up i nto the bypass system precl udi ng ef $\mathrm{f} i \mathrm{ci}$ ent bypassing of $\mathrm{fi}$ sh and requiring the bypass to be shut down. In essence, different segnents of an eval uati on my need to be performed at di fferent fl ous due to structural and operational constrai nts on where we can coll ect and sample fi sh.

To performan effecti ve eval uati on of a $j$ uveni l e bypass facility, consi derati on must be gi ven to the desi gned operati on of the i rrigation canal. To mesh the occurrence of canal operations at maxi mum desi gn fl ow with test fish availability can be a maj or obstacle. The tuo may not necessarily go hand-i n-hand. Tests my have to be run pri or to ful I canal uaterup if test fïsh are onl $y$ avai I able i $n$ a certai $n$ peri od of ti ne. If possible, al I aspects of a normal operation must be adhered to during an eval uation to get the ful $I$ benefit of the eval uation. We attempted to coordi nate eval uati on acti vi ti es at Three MIe Fal Is Dam with operation of the diversi on facility at maxi mum desi gn fl ow as mich as possi ble. 


\section{RECOMMENDATIONS}

Based on thi s year's experi ence in preparing for the eval uation of the VEI D Canal $\mathrm{j}$ uveni le fi sh bypass faci lity at Three MI e Fal Is Dam devel oping the eval uati on sampl ing pl an, and conducti ng prel i mi nary preeval uati on acti vities at upri ver dans, we of fer the foll owing suggesti ons for fut ure eval uations.

1. Capt ure faci liti es should be desi gned wel I in advance of thei $r$ i ntended use to provi de sufficient ti me for fabrication. Del ays in fabricati on and ot her unf or eseen probl ens need to be taken i nto account in the esti mation of total ti me requi red.

2. I $n$ determi ni ng staffi ng needs to conduct an eval uati on, a I i beral and real i sti $c$ approach shoul $d$ be used to ensure that the study is adequatel y staffed.

3. Instal I ati on of fyke net gromets should be performed in the field to nore preci sel y al i gn gromet hol es with frame bolt hol es. The el i mination of al I edge gaps is of paramount i mportance i $n$ conducting an effecti ve screen l eakage test.

4. Acti vi ty coordi nati on and i nf or mat i on di ssem nat $i$ on wi th vari ous af fected agenci es and i ndi vi dual s should be a pri ority task pri or to an eval uation. Thi s shoul d el $i$ mate conf usi on and potenti al conflicts during the eval uation, and ensure a snoother operation.

5. I nf ormati on needs of ot her agency personnel shoul d be determi ned pri or to the eval uati on to ensure appropri ate i nf or nati on is collected and compiled in the field.

6. Col l ecti on traps shoul d be tested at desi gned operating I evel $s$ at thei $r$ respecti ve l ocati ons to properly eval uate trap desi gn for effectiveness and efficiency. During the desi gn process, detailed pl anning and consul tati on shoul d be undertaken to avoi d desi gn fl aus.

7. A I equi pnent needs shoul $d$ be adequat el y assessed to avoi d conduct i ng an eval uat $i$ on wi th i nsuf fi ci ent equi pnent and suppl $i$ es. Backup gear and al ternati ve methods shoul d be devi sed to be prepared for unpl anned energencies.

8. I nt raagency and i nteragency personnel af $\mathrm{f} i \mathrm{I} i$ at ed wi th an eval uat i on shoul d be notified in advance of the study schedule and be i nvi ted to observe eval uati on operations.

9. Sampl ing pl ans for fut ure eval uations shoul d be ci rcul at ed for detailed peer revi ew and criti que.

10. Si te i nspecti ons should be performed in detai I to assure compati bility with equi pnent needs and study acti viti es.

11. A f ul I scal e eval uati on shoul d be performed at Maxuel I and hestl and Dam j uveni l e fish bypass systens i 1992 to determi ne specific 
def $i$ ci enci es i n desi gn, construction, and operati on and to ensure that the systens functi on as intended. The study obj ecti ves shoul d be si milar to those for the Three Mle Falls Dam j uvenile fi sh bypass facility eval uati on conducted in 1991.

12. Resul ts of the $1991 \mathrm{j}$ uveni I e fi sh bypass faci I ity eval uation at Three MIe Fal Is Dam should be presented in a 1992 i nteri m progress report. Activities conducted to prepare for eval uations of the $\mathrm{j}$ uveni le fi sh bypass systens at Mexuel I and West I and di versi on dans shoul d al so be presented.

13. Wist ewater channel s at Maxuel I and Westl and di versi on dans shoul d be eval uated to ensure safe fish passage during periods of high river fl ow Potential for juveni le fi sh passage, strandi ng, and i nj ury, and adul $t$ fi sh attraction shoul $d$ be i nvestigated. 


\section{REFERENCES}

Boyce, R. R. 1986. A comprehensi ve pl an for rehabilitation of anadronous fish stocks in the Untilla River basin. Fi nal report to Bonnevi I l e Power Admi ni strati on by Oregon Departnent of Fi sh and $V^{*}$ I dl i fe. Cont ract No. DE- Al79-84BP18008. Portl and, Oregon.

Fast, D. E. , J. D. Hubbl e, and B. D. Wat son. 1986. Yaki ma Ri ver spri ng chi nook enhancenent st udy. Prepared by the Di vi si on of Fi sheri es, Yaki ma I ndi an Nati on, for the Bonnevi ll e Power Admi ni stration, Portl and, Oregon.

Hosey \& Associ ates. 1988. Eval uati on of the effecti veness of $\mathrm{f} i \mathrm{sh}$ protection facilities. Chandl er facility eval uation. Report by Hosey and Associ ates Engi neering Company for the U.S. Bureau of Recl anati on.

Hosey \& Associ ates. 1989. Eval uati on of the effecti veness of $\mathrm{fish}$ protection facilities. Roza facility eval uation. Report by Hosey $\&$ Associ at es Engi neeri ng Company and Fi sh Managenent Consul tants for the U.S. Bureau of Recl amation.

Hosey \& Associ ates. 1990. Eval uati on of ef fecti veness of $\mathrm{fish}$ protection facilities. Easton facility eval uation. Report by Hosey \& Associ at es Engi neering Company and Fi sh Management Consultants for the U.S. Bureau of Recl anation.

Knapp, S. M, and D. L. Ward. 1990. Pages 4- 32 i n A A N gro, edi tor. Eval uat $i$ on of $j$ uveni $l$ e $f i$ sh bypass and adul $t$ fi sh passage facilities at Three Mle Fal Is Dam Unatilla Ri ver. Annual Progress Report to Bonnevi Il e Power Admi ni stration, Portl and, Oregon.

Neitzel, D. A, C. S. Abernethy, E. W Lusty, and L. A Prohamer. 1985. A fi sheri es eval uati on of the Sunnysi de Canal fi sh screening facility, spring 1985. Prepared by the Pacific Northuest Laborat ory, Ri chl and, Whishi ngt on, for the Di vi si on of Fi sh and Vil dl i f e, Bonnevi I l e Power Admi ni strati on, Portl and, Oregon.

Neitzel, D. A, C. S. Abernethy, and E. W Lusty. 1987. A fi sheri es eval uati on of the Ri chl and and Toppeni sh/Sat us Canal fi sh screeni ng facilities, spring 1986. Prepared by the Pacific Northwest Laboratory, Ri chl and, Whshi ngt on, for the Di vi si on of Fi sh and

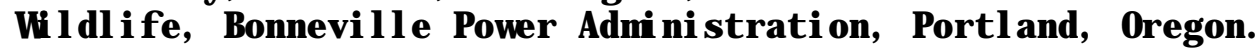

Nei tzel , D. A , C. S. Abernethy, E. W Lusty, and S. J. Whmpl er. 1988. A fi sheri es eval uati on of the Ri chl and and Whato Canal fi sh screening facilities, spring 1987. Prepared by the Pacific Northwest Laboratory, Ri chl and, Wishi ngt on, for the Di vi si on of Fi sh and Vill di fe, Bonnevi I le Power Admi ni stration, Portl and, Oregon.

Nei tzel, D. A , C. S. Abernethy, and E. W Lusty. 1990a. A fi sheri es eval uat $i$ on of the Toppeni sh Creek, Whpato, and Sunnysi de $f i$ sh 
screening facilities, spring 1988. Prepared by the Pacific Northuest Laborat ory, Ri chl and, Wtshi ngt on, for the Di vi si on of Fi sh and Vill dl i fe, Bonnevi I l e Pouer Admi ni strati on, Portl and, Oregon.

Neitzel, D. A , C. S. Abernethy, and G. A Mrtenson. 1990b. A fi sheries eval uation of the Westsi de Ditch and Town Canal fi sh screening facilities, spring 1989. Prepared by the Pacific Northuest Laboratory, Ri chl and, Wishi ngt on, for the Di vi si on of Fi sh and Vil dl i fe, Bonnevi I I e Power Admi ni strati on, Port l and, Oregon.

NPPC (Northwest Pouer PI anni ng Counci I). 1987. Col unbi a Ri ver basi $n$ fi sh and wi Idl i fe program (as anended). Northwest Pover PI anni ng Council, Portl and, Oregon.

USBR (U. S. Bur eau of Recl anati on). 1989. Prel i mi nary desi gner' s operating criteria. Three Mle Fal Is Diversi on Daml eft-bank fish faciliti es, Unatilla Project, Oregon. Denver, Col orado. 


\section{REPORT B}

1. Eval uati on of the $\mathrm{j}$ uveni I e fi sh bypass facility in the Utst Extensi on I rrigati on Di strict Canal at Three MIe Fal Is Dam

2. Docunentati on of passage of $j$ uveni l e sal moni ds through the bypass facility and east-bank adul $t$ fi sh I adder.

Prepared by:

M chael C. Hayes

Suzanne M Knapp

Anthony A Nigro

Oregon Department of Fi sh and $V^{*} I \mathrm{dl}$ i fe

2501 S. W Fi rst Avenue

P. 0 Box 59

Portl and, Oregon 97207 


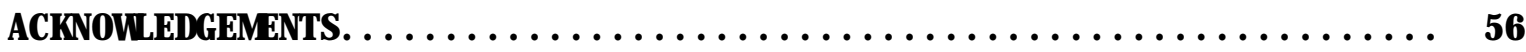

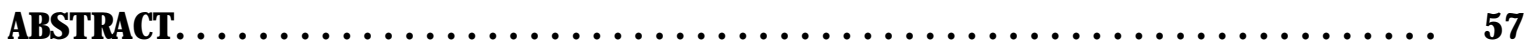

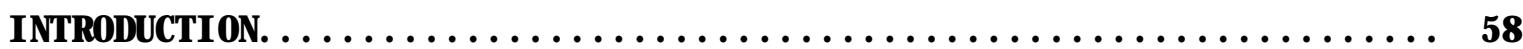

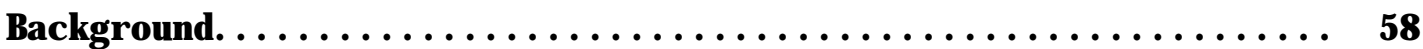

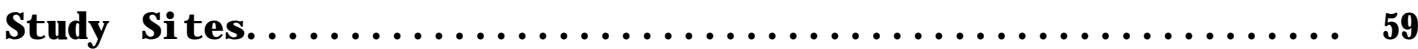

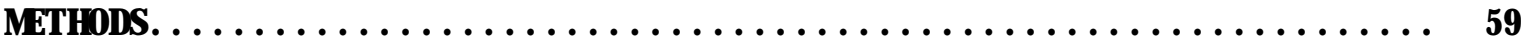

Three MIe Fal Is Dam J uveni I e Fi sh Bypass Faci lity Eval uati on. . . 59

Screen I nj ury ............................. 62

Bypass Pi pe and outfal I I nj ury Test ................ 63

Headgate I nj ury Test .......................... 63

Drum Screen Leakage Test ........................... 64

Travel i ng Screen Leakage Test ....................... 65

Travel Ti me .................................. 65

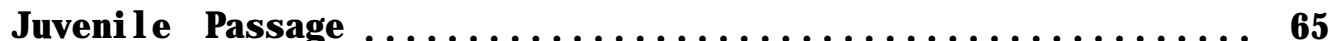

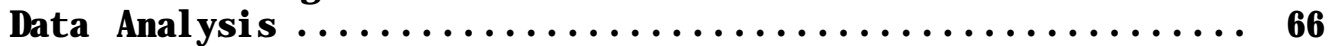

Acti vi ti es at Maxuel I, Méstl and, and Col d Spri ngs Di versi on Dans...................67 67

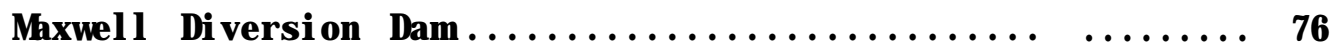

Westl and Di versi on Dam.......................... 68

Col d Spri ngs Di versi on Dam. . . . . . . . . . . . . . . . . . . . 68

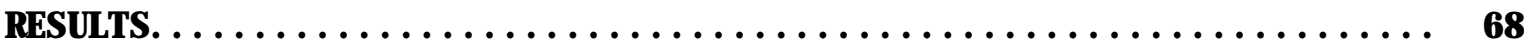

Three M I e Fal I s Dam J uveni I e Fi sh Bypass Faci lity Eval uati on. .. 68

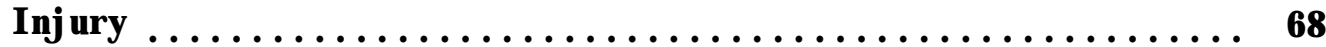

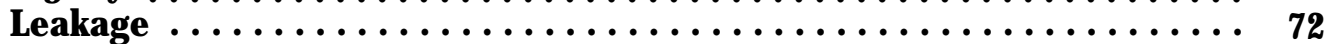

Travel Ti ne .................................. 77

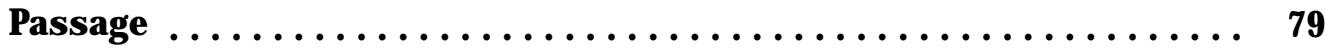

Acti vi ti es at Maxuel I, Wèstl and, and

Col d Spri ngs Di versi on Dans................... . . . . 79

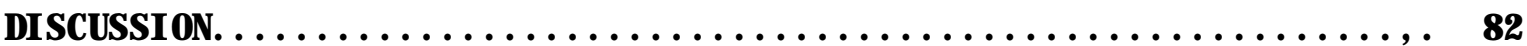

Three M I e Fal Is Dam J uveni I e Fi sh Bypass Eval uati on. . . . . . . . . 82

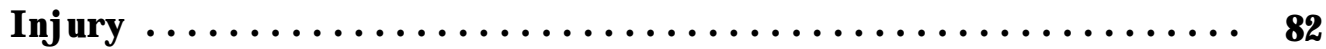

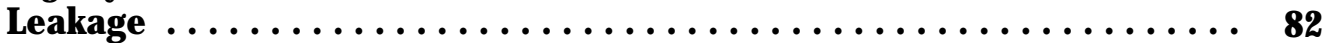

Travel Ti ne ....................................... 83

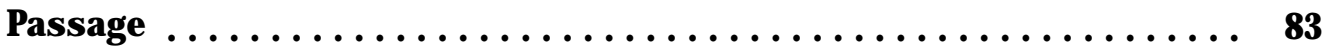




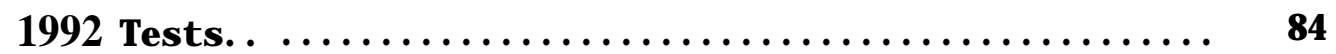

Operati onal and Struct ural Problens at Three M I e Fal I s Dam.... 84

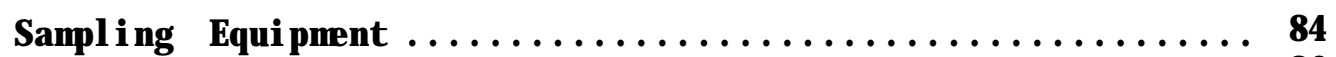

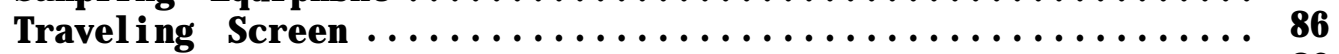

Operating Criteria ....................... 86

Acti vi ti es at Mexuel I, West I and, and

Col d Spri ngs Di versi on Dans . . . . . . . . . . . . . . . . . . . . 87

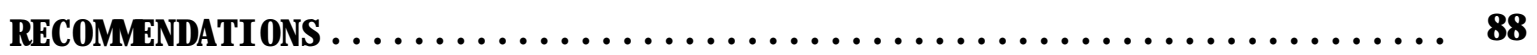

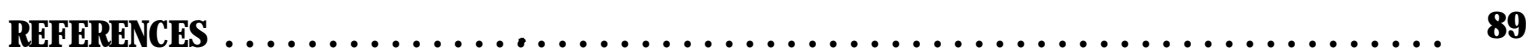

APPENDIX A 1992 PI anned Acti vities for the Unatilla Ri ver

Col d Spri ngs Di versïon Dans ........................ 91 


\section{ACKNOVZEDGEMENTS}

We greatl y appreci ated the efforts of our fi el d crew in conducting the acti viti es of the study. Speci fi call y, we thank Robert Muel I er for hi s assi stance in di recting study acti vi ti es and i n desi gni ng the Col d Spri ngs trap. We al so thank Jill Berry, Eric Veach, Kathy Terrel I, Ti a Jensen, and David Guard of our seasonal staff for thei $r$ nork in the fi el d performing the eval uation. We appreci at ed the assi stance of Rosanna Tudor and J i I I Berry in summarizing the data. We thank Jerry Franke of the West Extensi on Di strict for his support and cooperation. We al so thank Gerry Rowan of the Conf ederated Tri bes of the Unatilla I ndi an Reservati on and his techni ci ans for noni tori ng our test $f i$ sh at the $M$ nthorn accli mati on pond and $f$ or thei $r$ assi stance in I oadi ng fi sh to be used in tests. We al so appreci ated the assi stance of Ray $\mathrm{HII}$ and Whde Bergeson of the I rrigon Hatchery in provi di ng us with fall chi nook.

We extend our appreci ati on to J ay Mercotte and J erry Bauer of the Bonnevi I l e Power Adm ni strati on for thei $r$ assi stance wi $t h$ cont racti ng of f unds. We thank Mary Buckman and Enery Wigner for thei critical revi ew of the manuscri pt. 


\section{ABSTRACT}

We report on our effort from Apri I through Septenber 1991 to eval uate the j uveni I e fi sh bypass faci I ity i $n$ the West Extensi on I rri gation Di st ri ct Canal at Three MIe Fal Is Dam on the Unatilla Ri ver. We al so report on $\mathrm{j}$ uveni I e sal moni d outmigrati on through the east-bank adul t fi sh I adder i $n$ through the bypass faci lity i $n$ 1991. We i ncl ude i nf or mation on prel i mi nary acti vi ti es to prepare for fut ure eval uati ons at Maxuel I, Westl and, and Col d Spri ngs di versi on dans. Tests at Three MI e Fal I s Dam showed that races of spring and fal I chi nook sal non (Oncorhynchus tshawytscha) and sumer st eel head (Oncorhynchus mykiss) were not inj ured during passage through the enti re fi sh bypass facility. We al so observed no si gni fi cant l eakage of chi nook sal mon fry through the drum screen system with screening effici ency approachi ng $100 \%$. Some i mpi ngenent of fry and subyearl i ngs was observed on the secondary travel i ng screen because of unf avorable hydraul i cs and i nsuffici ent spray water at one I ocation. Fi sh noved freel y through the upper screening facility and general Iy moved more rapi dl y during ni ght ti me tests. Fi sh movenent was del ayed i $n$ the I ower bypass outfal $I$ at $f I$ ous of 5 cubi $c$ feet per second ( $c f s$ ), but qui ckened when fl ous were i ncreased to 25 cf s. Al though movenent of $f i$ sh in the facility was nore rapid at ni ght, the migration of ri ver-run sal monids ( probabl y coho and chi nook sal mon) showed a di sti nct di urnal peak. Passage through the east-bank I adder showed that some fi sh movement was correl at ed with hi gher river fl ous. We of fer recomendati ons for struct ural and operati onal i mprovements i $n$ the West Extensi on I rri gati on Di stri ct Canal j uveni le fish bypass facility at Three MIe Fal Is Dam We fabricated and part l y tested col I ecti on systens for-the $j$ uveni l e fi sh bypass facil i ti es at Maxuel I, West I and, and Col d Spri ngs di versi on dans to be used i $n$ f ut ure eval uati ons. The pri mary probl em encountered with the Maxuel I trap was a backwash eddy that stranded fish. Preliminary monitoring of fyke net operati on at the West I and Di versi on Dam showed that the net uorked uel I and onl y requi red mi nor nodi fications. During 1992, we will conti nue tests at Three M l e Fal Is Dam and prepare for eval uati on acti vi ti es at Westl and Dam i $n$ 1993. 


\title{
I NTRODUCTI ON
}

\author{
Backgr ound
}

The Northwest Power PI anni ng Counci I's (NPPC) Col unbi a Ri ver Basi n Fi sh and $V^{*} I$ dl i fe Program ( 1987) call ed for the i mprovement of anadronous $f$ i sh passage faciliti es at i rrigation di versi on projects in the Unatilla Ri ver Basi $\mathrm{n}$ in the form of passage i mprovenents (Section 1403, Measure 4. 2). Under contract with the Bonnevi I l e Power Admi ni strati on (BPA) and i n cooperati on with the Conf ederated Tri bes of the Unati II a Indi an Reservation (CTU R) and fi sh and widl ife agenci es, the U.S. Bur eau of Recl anati on (USBR) devel oped and carried out a program to i mprove fish passage faciliti es at Unatilla Ri ver di versi on dans. St at e- of - the-art passage faciliti es at Three MIe Fal Is Dam were the fi rst to be constructed, fol I owed by Maxuel I and Col d Spri ngs di versi on dans. Westl and Di versi on Dam passage faci l i ti es were reconstructed under the di recti on of the Oregon Departnent of Fi sh and Vil dll ife (ODFW. Passage facilities at Stanfield Di versi on Dam are currently in the desi gn phase by CDFW staff. New screening facilities are i ntended to prevent j uveni l e sal moni ds from ent eri ng the i rri gati on canal s by gui di ng them unharned back to the river from whi ch they were di verted. Eval uati on of the passage $i$ mprovement projects at the $f i$ ve maj or di versi on dans on the Unatill a Ri ver was suggested i $n$ A Comprehensi ve PI an for Rehabi I itati on of Anadronoos Fi sh Stocks in the. Unati I la Ri ver Basi n (Boyce 1986).

Construction of si milar fish passage and protection facilities at maj or ( Phase I) i rri gati on di versi ons i n the Yaki ma Ri ver Basi $n$, Whshi ngt on, has al so been funded by BPA and USBR under Secti on 803 (b) of the NPPC s Col unbi a Ri ver Basi n Fi sh and Vil dl i fe Program (NPPC 1987). Eval uations of the effectiveness of these fish screening facilities on the Yaki ma River have been carried out by Neitzel et al. (1985, 1987, 1988, 1990a, 1990b) and Hosey \& Associ at es (1988, 1989, 1990a). We consi dered thei $r$ experi ences when desi gning eval uations of fish screening facilities in the Unatilla River Basi $n$.

We began the fi rst year of our eval uat i on of $j$ uveni I e fi sh bypass facilities in the Unatilla Ri ver at Three MIe Fal Is Damin Novenber 1989. During thi s period, we operated and eval uated the effi ci ency of the $j$ uveni I e fi sh bypass system i $n$ the West Extensi on I rri gati on Di stri ct (VEI D) Canal. I mprovements were made to the fi sh bypass collecti on facilities, a system was devel oped to col l ect $\mathrm{j}$ uveni l e sal moni ds at the bypass outfal $\mathrm{I}$, and prel i mary i nf or mat $i$ on on $j$ uveni l e fi sh passage condi ti ons was col l ected ( Knapp and Whrd 1990). Report A of thi s report describes our approach to and preparat ory activiti es for conducti ng second year study objecti ves.

In Report B we present resul ts from our ef forts toward addressing second year study obj ecti ves. These study objectives were to (1) eval uate the passage of $\mathrm{j}$ uveni l e sal moni ds through the bypass system i $n$ the VEI $D$ Canal facility at Three MIe Fal Is Dam i ncl udi ng the eval uati on at desi gn fl ow of i nj ury and nortal ity rates, and passage of $j$ uveni l e sal moni ds through and over the screens, and (2) performprel i mary activiti es that would facilitate passage eval uati ons at the Mexuel I, Westl and, and Col d Spri ngs di versi ons dans i n coming years. 


\section{Study Si tes}

A descripti on of the Three MIe Fal Is Dam and associ at ed VEIID Canal and fi sh screeni ng facilities is in our fi rst annual progress report (Knapp and Whrd 1990). A descri pti on of ' the Mexuel I and Westl and di versi on dans i s i ncl uded i n Report A of this report. Col d Spri ngs Di versi on Dam i s I ocat ed at Ri ver MI e 29. 2; reconstructi on of the ol d j uveni l e fi sh screening faci I ity was compl eted in 1990. Components of the new facility and associ at ed canal struct ure i ncl ude a trashrack, 10 rotary drum screens, a bypass chanber and out l et, and a canal check and wast eway structure. Al si tes are I ocated on the I ower Unatilla Ri ver (Figure 1). A schenatic di agramill ustrates the fi sh bypass facility at Three MIe Fal Is Dam (Figure 2).

\section{METHODS}

\section{Three M I e Fal Is Dam J uveni I e Fi sh Bypass Faci I ity Eval uati on}

The eval uati on of the $j$ uveni l e fish bypass facility at Three MIe Fal Is Dam consi sted of several different tests to eval uate vari ous components of the facility at designed operating criteria and flow The pri mary tests conducted were the screen i nj ury, bypass pi pe and outfal I inj ury, and drum screen l eakage tests. Secondary tests eval uat ed headgate i nj ury and travel ing screen l eakage. We conducted these tests with different speci es or races (si zes) of chi nook sal mon (Oncorhynchus tshawytscha) and sumer steel head (Oncorhynchus myki ss) i n Apri I and My of 1991. Methods are descri bed i n det ai I i n Report A.

We conducted al I inj ury tests usi ng yearling spring chi nook sal mon and summer steel head and subyearling fal l chi nook sal non. For the headgate i nj ury test, we used $f i$ sh saved from previ ous tests that were in good condi $t i$ on. Drum screen I eakage was tested with fall chi nook sal mon fry. These species were sel ected because they are present in the Unatilla River system Al fish used in the screen inj ury tests were freeze-branded with a uni que group brand and hel d in separate contai ners for 48 hours to 72 hours to al low the brand to set and the fish to accli mate. For the screen l eakage test, control fal I chi nook sal mon fry uere marked with bi snark brown dye to differenti ate them from the treatment groups and $p l$ aced i $n$ an aerated contai ner for one hour to al I ow the dye to set. Marked groups were hel d in I arge tanks suppli ed wi th pumped river water from the canal. In addition, fl oating net pens were used to hol d fish in the canal headworks area or in the river when necessary. Mre detai l ed i nf ormati on on test fi sh, brandi ng, and the hol di ng system i s avai I abl e in Report A

We determined fish condi ti on for al I i nj ury tests using descal ing criteria devel oped by the U. S. Army Corps of Engi neers (Neitzel et al. 1985) and described in Report A Fi sh condi ti on was based on the percentage of scal e loss in each of fi ve desi gnated secti ons per si de of fish. Fi sh were cl assi fi ed as "heal thy" (scal e l oss $\leq 3 \%$ per secti on), "parti al I y descal ed" (scal e loss > $3 \%$ but < $40 \%$ per section), or "descal ed" (cumul ative scal e I oss $240 \%$ in any two sections). We al so recorded observations of ot her inj ury types such as cuts, brui ses, eye or head i nj uri es, and torn opercul uns. 


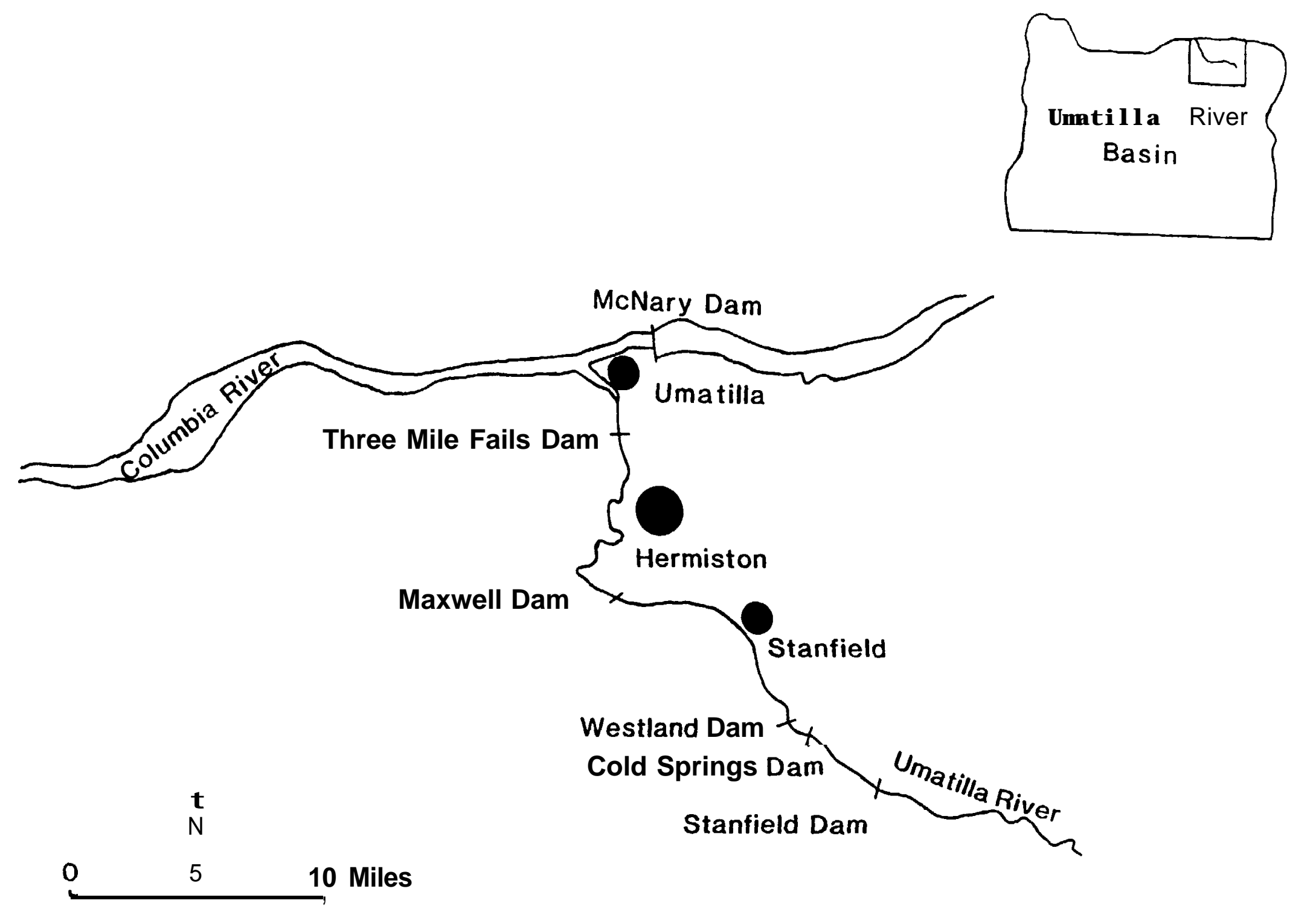

Fi gure 1. Locations of di version dans on the I over Unatilla River, Oregon. 


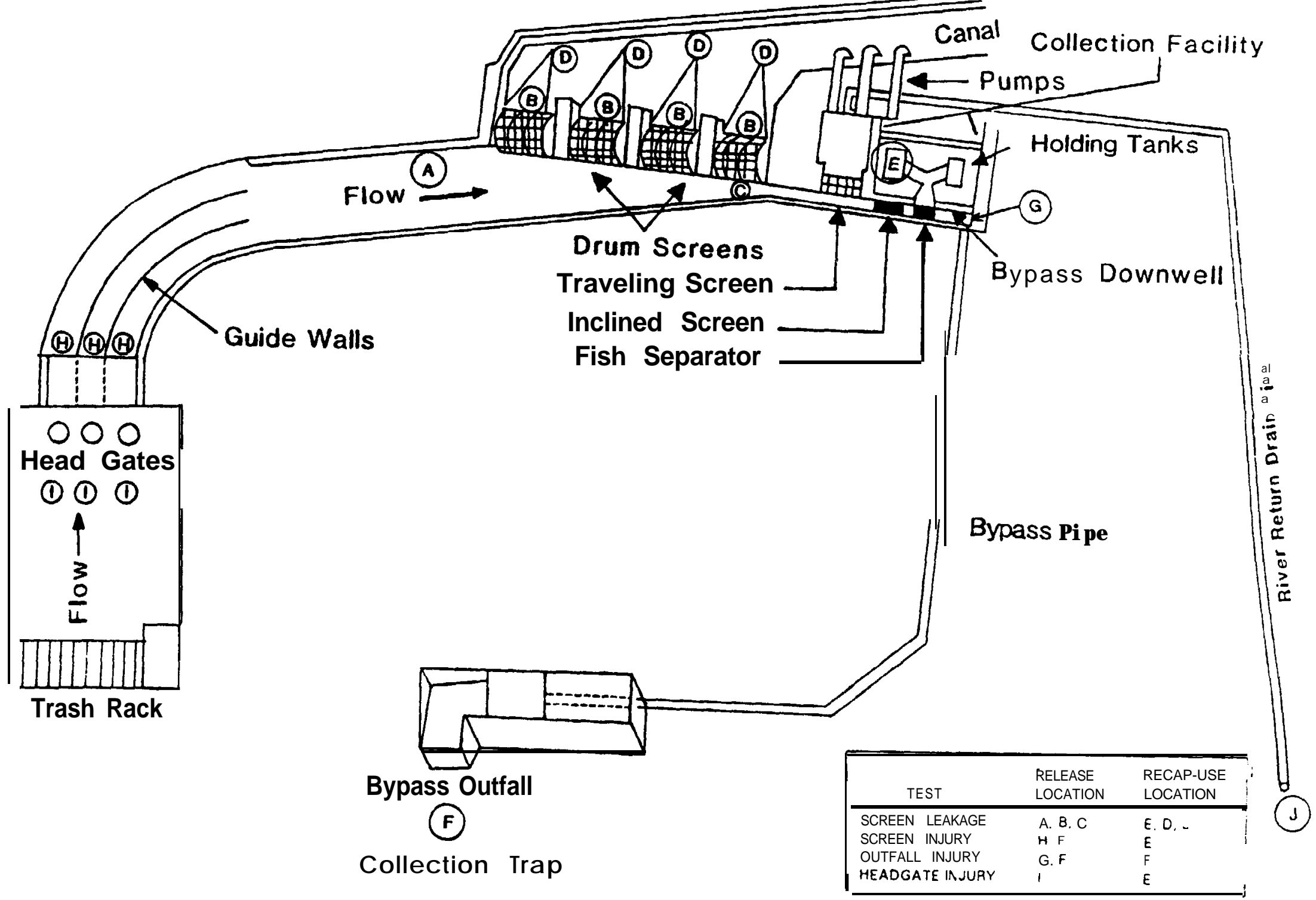

Fi gure 2. Schenatic of the VEI D Canal juveni le fi sh bypass facility at Three M le Fal Is Dam i ncl uding sampling I ocations for rel ease and recapt ure of $f i$ sh. 
Screen I nj ury

To eval uate i nj ury and mortal ity rates associ at ed with the drum screens, we rel eased repl i cate groups of heal thy, freeze-branded fi sh upstream of the drum screens and recapt ured them at the bypass col I ecti on faci i ity

(tr eat ment). We al so rel eased repl i cate groups of heal thy fi sh (cont rol ) di rectl y i nto the col l ecti on facility (sampl e tank) to al I ow us to eval uate i nj ury caused by the coll ection and handling process. Al recapt ured fi sh uere exami ned for descal ing and other i nj uri es.

We conducted tests with spring and fal I chi nook sal mon during the day and at ni ght and with summer steel head during the day from 23 April to 9 May 1991. We conducted tests on three different dates with up to three repl i cates tested each day. Treat nent and control fish uere rel eased on the same day. Each test consi sted of approxi matel y three 100-fish groups for each speci es or race of test fish. We rel eased treat ment groups at approxi matel y 0900 hours and 2100 hours, respecti vel $y$, for three consecuti ve 24-hour peri ods. Treat nent groups were rel eased i medi at el y fol l owing the rel ease of the control groups i nt o canal fl ows rangi ng from 116 cubi c feet per second (cf s) to 149 cfs ( 77 99\% of maxi mum desi gn canal fl ow). Occasi onal ly, cont rol groups were pool ed, creating onl y one group per day. A $10 \%$ subsampl e from each repl i cate group uas exami ned for condi ti on bef ore rel ease to ascertai $n$ pre-rel ease condi $t i$ on. These subsample fish were not returned to thei $r$ groups.

Treat ment groups were rel eased i mmedi atel y bel ow the headgat es i $n$ each of three fl une secti ons in the canal headworks ( see Fi gure 2). Groups of control fi sh were rel eased di rectly i nto the col l ecti on facility sample tank and handl ed during exami nati on in the same nanner as the treat nent fish. Wh fol l owed operati on criteri a for a sampl ing mode when capt uring rel eased test fi sh in the col lecti on facility. Thi s i ncl uded the i nstal I ati on of sampl ing equi pnent (orifice pl ate, i ncl i ned screen, fi sh separator), and operati on of the travel ing screen and pumpback pumps, and the proper setting of wei $r$ gate positi ons and headuorks water I evel s (USBR 1989). On occasi on, we parti al I y opened the 21-inch di aneter drai $n$ pi pe gate to ret urn water to the river in I i eu of pump operation.

We recapt ured treatment fi sh in the sampl e tank at the bypass col l ecti on facility ( see Fi gure 2). Fi sh were crouded and renoved from the tank every hour to determine travel ti me and prevent tank crouding. Treat nent fi sh were capt ured for at I east 96 hours after rel ease to al low suffici ent ti ne for a 95\% recovery. Fork I engths were taken from a random sel ecti on of cont rol and treat ment fish.

Ri ver-run fi sh col l ected during the eval uati on were separated from test fish and returned to the river. If necessary, we anest hetized al I fish to separate test from river-run fish. We exami ned test fi sh i medi atel y upon recapt ure or transferred them to the hol di ng cont ai ners for I ater processi ng. Anesthetized ri ver-run and test fi sh were $p l$ aced in a hol di ng tank to recover from the anestheti $c$ and then rel eased into the bypass downuel I. A I test fi sh were pl aced i $n$ an anest het i c trough and anest het i zed wi th Fi nquel ( Fi sh condi ti on was determi ned and recorded on descal ing forms. We exam ned fi sh for descaling i $n$ the col lection facility, whi ch i ncl uded an overhead canopy for protection from the weather and a hi gh pressure sodi umlight to 
mai ntai $n$ consi stent li ghting condi tions. Fi sh i n good condi ti on were retai ned for use in secondary tests.

\section{Bypass Pi pe and Outfal I I nj ury Test}

To eval uate i nj ury and nortal ity rates associ ated wi th the bypass pi pe and bypass out $f$ al $I$, we rel eased repl $i$ cate groups of $f$ reeze-branded heal thy fi sh i nt o the bypass downwel I, recapt ured them i $n$ the bypass outfal I col I ecti on trap (fI oating net pen), and exami ned the fish for descal $i$ ng and ot her i nj uri es (treatment). We al so rel eased repl i cate groups of fi sh di rectly i nto the bypass outfal I col l ection trap to al I ow us to eval uate i nj ury caused by the collection and handling process (control).

We conducted tests from 16 Apri I to 31 My 1991. General I y, we conducted tests on three different dates for each species or race of test fi sh and at bypass fl ous of 5 cfs and 25 cfs. Each test consi sted of three, approxi matel y 100-fish groups. A $10 \%$ subsample from each treatment and control group was exami ned pri or to rel ease to ascertai $n$ pre-rel ease condition. These subsampl ed fish were not returned to thei $r$ groups.

The operati on criteri a for bypass fl ow were adhered to when performing the tests. Thi s i ncl uded the instal l ati on of the restrictive orifice pl ate for 5-cfs fl ow and the concurrent operation of the travel ing screen and pumpback pumps (USBR 1989). Wei $r$ gate positi ons for both fl ow regi nes were al so properly set according to operating criteria. During the 25-cfs tests, ue i nstal I ed a bypass channel stopl og to reduce fl ous during control rel eases and subsequent net positioni ng. The stopl og was renoved to achi eve a ful I 25cfs fl ow before rel easing the treatment groups.

We rel eased control fish i nto the net pen i medi at el y bef ore rel easi ng treatment $\mathrm{fi}$ sh at the bypass channel vei $r$ crest upstream of the downuel $\mathrm{I}$. Therefore, both groups were in the net pen si mul taneousl y during the recapt ure interval. To capt ure the maj ority of the test fish, the net pen remai ned i $n$ position for about one hour. We retrieved the net pen after the prescribed i nterval, and retrieved control fi sh and test fi sh, pl aci ng them in cont ai ners for i medi ate exami nation. Ri ver-run fish were rel eased to the river. We examined $f i$ sh for i nj ury in the same manner as in the screen i nj ury test. Fi sh were all owed to recover from the anesthetic i $n$ net pens $p l$ aced i $n$ the river prior to rel ease.

\section{Headgate I nj ury Test}

To eval uate i nj ury and nortal ity associ ated with passage through the headgates, we rel eased groups of previ ousl y used, good condi ti on fi sh upstream of the headgates, recapt ured them at the col l ecti on facility, and exami ned them for i nj ury or descaling. We used the resul ts fromtreatnent fi sh in the screen i nj ury tests that were rel eased downstream of the headgates as a control. During testing, we fol l owed normal canal operati ons and operati ng criteria for a sampling node at the collection facility (USBR 1989). Al three headgates were ful I y open. 
We conducted three dayti ne tests and two ni ghtti ne tests for spring chi nook sal mon from 30 April to 2 May 1991, and two dayti ne tests and two ni ghtti me tests for $f$ al I chi nook sal non on 7 and 8 My 1991. The number of fi sh rel eased i $n$ each test ranged from 77 to 190 . We di d not subsample test fish to determine pre-test fish condition, but, for purposes of anal ysis, ue assumed that al I fish began the test in good condition. Fish were rel eased in separate groups in front of the headgates ( see Fi gure 2).

Fi sh were recapt ured i $n$ the bypass col l ecti on facility at hourl y i nt erval s, and exam ned for descal i ng and ot her i nj ury fol l owi ng the same procedure used in the screen inj ury test. We recorded fish condition, and ti ne of rel ease and recapture. After processing, we rel eased the fish back to the river.

\section{Drum Screen Leakage Test}

To eval uate passage of $\mathrm{j}$ uveni $\mathrm{I}$ e sal moni ds through (I eakage) and over ( $i$ mpi ngement) the drum screens, we rel eased treatnent groups of $f$ al I chi nook sal non fry upstream from the screens and recapt ured them ei ther in fyke nets pl aced i medi at el y behind the screens in the VEI D Canal or in the bypass collection facility ( see Figure 2). We al so rel eased groups of bi smark-browndyed control $f i s h$ in the fyke net mouth to obtai $n$ an esti nate of net collection and retenti on efficiency. An esti mate of bypass col lecti on effici ency was obtai ned by rel easing groups of control fi sh in the bypass channel and recapt uring them in the sampl e tank at the col l ecti on facil ity. We al so moni tored fi sh passage over the screens during tests to esti mate rol l over caused by i mpi ngement. Because sal noni d fry are not a normal cont ingent of the $\mathrm{j}$ uveni le outmigration, our test fry were easil y di scernable.

We performed tests at a canal flow of 74 cfs to 78 cfs from 5 April to 10 Apri I 1991. Three tests were made, each duri ng midmorni ng and separat ed by 48-hour peri ods. The 48-hour i nterval uas necessary to al I ow fi sh from one group to cl ear the system bef ore rel ease of the next group, si nce test fi sh groups could not be differentiated.

Because of our i nabi I ty to desi gnate separate groups for each test, we rel eased a si ngl e $300-\mathrm{fi}$ sh treatment group upstream of the screens, and a single 300-fish control group i $n$ the bypass channel on each test day. Control fish were al so rel eased behi nd each of the four screens in the net nouth in separate 75-fish groups. Each test was desi gned to compri se $900 \mathrm{fi}$ sh for three days, for a total of 2, 700 fry.

To capt ure test fish in the collection facility, we foll owed the operation criteria for sampling. Thi s i ncl uded the i nstallation of bypass channel sampli ing equi pment, operati on of the travel ing screen, openi ng of the ri ver return drai $n$ pi pe ( pumpback pumps could not be operated wi th fyke nets i $n$ pl ace), and proper setting of wei $r$ gate positi ons and headworks water l evel s (USBR 1989).

Fyke nets were pl aced behi nd the screens bef ore rel eases. The fyke nets were noni tored for approxi matel y 48 hours after rel ease to capt ure control fish and any test fish that leaked past or rolled over the screens. At 4- hour to 6-hour i nterval s during thi s 48-hour peri od, we exami ned the contents of 
the fyke net by i ndi vi dual I y raising the nets, removi ng the contents of the cod end, and pl acing the contents in buckets. The nets were cl eaned with uater supplied from the travel ing screen spray water pump and i medi atel y l owered back into place. We col l ected fry from the sample tank in the bypass collection facility every hour. Data on river-run fish collected in the sampl e tank were recorded, and then the fi sh were ret urned to the river.

We recorded the numbers of fry retrieved (treat ment and control) from each fyke net and from the hourly sample tank crouding. During the tests, we moni tored the drum screens for any i ndi cati on of fry $i$ mpi ngenent and documented numbers of rol l over fish. We recorded I engths of al I treat nent fi sh that passed through or over the screens. We recorded I engths from subsampl es of treat nent and control.fish.

\section{Travel ing Screen Leakage Test}

To determine if I eakage was occurring at the secondary travel ing screen, we i nstal I ed a fyke net at the terminus of the ri ver ret urn pi pel i ne ( see Report A). Any fish I eaki ng past the screen when the sl ui ce gate to the ri ver ret urn drai $n$ pi pe was open woul d be event ual l y capt ured in the fyke net. We pl anned to retrieve the contents of the fyke net on a hourly basis.

We were unable to devi se a nethod to capt ure fi sh i mpi nged on the travel ing screen during pumpback pump operation. However, we made two fi sh rel eases in the bypass channel to determine if we could di rectly observe i mpi ngement of fal chi nook sal mon fry on the traveling screen. On 24 April, we rel eased 110 fry into the bypass channel. The t no I O cfs pumpback pumps were in operation with the sl ui ce gate cl osed. On 2 Myy we made another rel ease of fry into the bypass channel with the river return drai $n$ pi pe opened more than 12 inches on the pi pe stem We adj usted the pi pe stem down to 9 i nches to reduce turbul ence; hydraul i c condi ti ons appeared si mi ar to condi ti ons during pumpback pump operation.

\section{Travel Ti ne}

We exami ned fi sh movenent during the screen i nj ury and bypass out fal I tests to determine if the fish bypass facility could del ay fi sh mgration. The ti me of rel ease and recapt ure was recorded to ascertai $n$ novenent rates through the facility. In the screen inj ury test, we esti mated travel ti me through the screen facility by cal cul ating the ti me to recapt ure $50 \%$ (mean travel ti me) and $95 \%$ of the test fish. In the bypass outfal I test, we esti mated fish travel ti me through the I ower bypass and outfall by computing the total number of test fish recaptured in one hour.

\section{J uveni I e Passage}

Fi sh passage i nf or mati on on $\mathbf{w}$ I d and hatchery-reared sal noni ds rel eased upstream from Three M I e Fal Is Dam was obtai ned during tests from 5 Apri I to 10 April, and from 23 Apri I to 9 My 1991. We sampled hourly al I fi sh entering the fish bypass facility and recorded the numbers of $\mathrm{w} I \mathrm{~d}$ and 
hatchery fish present. Because of the I arge number of fish noving through the facility, species of fish were conbi ned.

The numbers of $\mathrm{j}$ uveni $\mathrm{l}$ e sal moni ds novi ng through the east bank $\mathrm{f} i \mathrm{sh}$ I adder at Three MIe Fal Is Dam were documented in the spring of 1990 using vi deo cameras $\mathrm{pl}$ aced in the east I adder vi ewi ng wi ndow to record adul $\mathbf{t}$ passage. Vi deo tape i nf ormation was noni tored peri odi cally from 23 March to 7 June 1991. These vi deo tapes uere revi eued to determine the number and ti ming of downst ream mi grati ng j uveni I e sal moni ds usi ng the east-bank I adder. I ndi vi dual speci es coul d not be determi ned.

\section{Data Anal ysi s}

We used anal ysi s of vari ance (ANOVA) to test the hypothesi s that the rel at $i$ ve condi ti on of control and treatment fish were equal i $n$ al I i nj ury tests. Sources of vari ati on tested i $n$ each ANOVA were treatment versus control, and ti me of day (day or ni ght) or fl ow (5 cfs or $25 \mathrm{cfs}$ ). We chose as our si gni fi cance I evel a $\mathrm{P}$ val ue of $<0.10$. A I testing was compl et ed usi ng the General Li near Model Procedure in the SAS program for personal computers (SAS I nsti tute Inc. 1990).

I nj ury Esti mates: For purposes of anal ysi s, we cal cul at ed the pre-test condi ti on ( from subsampl es) and post-test condi ti on (from cont rol or treat ment test fish) of fish observed as percentages of recaptured i nj ured fish ( $t$ he sum of partly descal ed, descal ed, and ot her i nj ured fi sh). We then cal cul at ed net i nj ury rate as the difference between pre-test and post-test condi ti on.

We computed a $95 \%$ conf i dence i nterval about the net i nj ury rate for each treat nent and control group. In the headgate i nj ury test, no subsampl es to measure pre-test condi ti on were obtai ned. Ther ef ore, we assumed the condi ti on of treat ment $f i$ sh was equal to zero, meani ng that no i nj ured fi sh were present.

Screen Efficiency Esti mates: Weval uated the ability of the drum screens to prevent fish fromentering the i rrigation canal and gui de fish that encounter the drumscreens into the bypass. We esti nated screen effici ency for each test and for al I tests combi ned. We combi ned al I data from the vari ous tests to compensate for differences in test si ze and, theoretical Iy, in the number of $\mathrm{fish}$ encountering the screen.

Esti nates of screen effi ci ency were corrected for bypass col l ecti on effici ency $\left(E F F_{b c}\right)$ and net capt ure effici ency $\left(E F F_{n c}\right)$. We assumed net retention to be equal to net effi ci ency, gi vi ng it a val ue of 1 . The formul a for esti mating screen ef fi ci ency $\left(E F F_{S C}\right)$ was

$$
E F F_{s c}=1-\frac{x_{n e t}}{E F F_{n C} N}
$$

where 


$$
\begin{aligned}
X_{\text {net }}= & \begin{array}{l}
\text { number of } f i s h \text { rel eased upstream of the screens and } \\
\text { caught in the nets, and }
\end{array} \\
N= & \begin{array}{l}
\text { an esti mate of the total number of fish encount eri ing the } \\
\text { screens (it may be l ess than the actual number of fish } \\
\text { rel eased) }
\end{array}
\end{aligned}
$$

$$
\begin{aligned}
& \mathbf{N}=x_{\text {net }} \mathbf{t} \quad x_{\text {bc }} \\
& E_{\text {nc }} \quad E_{\text {bF }}
\end{aligned}
$$

where

$$
\begin{aligned}
& x_{b c}=t \text { he number of } f i \text { sh rel eased upst ream of the screens } \\
& \text { and caught in the bypass collection facility } \\
& E F F_{n c}=n_{n c} \\
& \text { Nnc } \\
& \mathrm{EFF}_{\mathrm{bc}}=\mathrm{n}_{\mathrm{bc}} \\
& \text { Nbc }
\end{aligned}
$$

where

$$
\begin{aligned}
& \text { nnc }=\text { the number rel eased } \mathrm{i} n \text { the net mout } h \text { and caught i } n \text { the net } \\
& N_{n c}=\text { the number rel eased in the net nouth, } \\
& \mathrm{nbc}=\text { the number of } \mathrm{fi} \text { sh rel eased in the bypass channel and } \\
& \text { caught in the bypass collection facility, and } \\
& N_{\text {bc }}=\text { the number rel eased i } \mathrm{n} \text { the bypass channel. }
\end{aligned}
$$

Acti viti es at Maxuel I, Westl and, and Col d Spri ngs Di versi on Dans

\section{Maxuel I Di versi on Dam}

We fabri cated a bypass trap for the Mexwel I Dam facility using an i ncl i ned pl ane design ( see Report A). We subsequently used the bypass trap at the Maxuel I screening facility on $6 \mathrm{~J}$ une 1991 to test for suitability and effectiveness in capturing fish without injury. Before testing, we constructed a 4- $\times$ I-i nch wooden frame and i nstal led tuo I/2-ton hoi sts to I ift and l ower the trap in pl ace in the bypass downuel I. We positioned the trap and channel wei $r$ boards so that approxi matel y a I 0 cfs bypass fl ow entered the trap. The trap angle was adj usted with the use of the pi vot-rod front entrance assembl y to achi eve a sui table, non-turbul ent water fl ow i nto the Ii ve box wi thout i mpinging fish.

We rel eased one 25- $\mathrm{fi}$ sh group of marked subyearling fal I chi nook sal mon upstream of the bypass near the midd e drum screen, and three 25-fi sh groups 
in the bypass channel. We retri eved the fi sh from the trap I i ve box, exami ned them for condi ti on, and documented observable probl ens with trap operation. Bypass channel rel eases were retri eved in 2 minutes; the drum screen rel ease uas retrieved i n $\mathbf{3 0}$ mi nutes.

\section{West I and Di versi on Dam}

We fabricated a fyke net and fl oating I i ve box assenbly for use in the j uveni I e fi sh hol di ng pond at the Westl and Damfi sh facility (see Report A). During mid-June, we depl oyed the modified fyke net in the hol di ng pond to test the effici ency and ef fectiveness of the net in capt uring fish. We i nstal I ed the fyke net i $n$ stopl og grooves at the upstream end of the pond. A 2- $x$ 12i nch board was pl aced across the pond to access the I i ve box. The pond $i$ nf I ow was adj usted to $4 \mathrm{cfs}$. We rel eased one 35- $\mathrm{f} i \mathrm{sh}$ repl $\mathrm{i}$ cate of dyed subyearli ing $f$ al I chi nook sal non downst ream of the bypass wei $r$ and a second 17- $f$ ish repl i cate upstream of the wei $r$. Subyearlings were retri eved from the I $i$ ve box 5 mi nutes to 10 mi nutes after rel ease and exam ned for condition. We documented operati on and desi gn def $i$ ci enci es for $f$ ut ure nodi fi cati ons.

\section{Col d Spri ngs Di versi on Dam}

We desi gned and fabricated an al umi num i ncl i ned pl ane trap for the bypass at Col d Spri ngs Dam The desi gn i ncorporated feat ures of the bypass channel, bypass downuel I, maxi mum desi gn bypass $f($ ow and avai l abl e struct ure for trap al i gnment and depl oyment. The $\mathrm{i}$ ncl i ned pl ane was $7.6 \mathrm{ft}$ I ong by $2.5 \mathrm{ft}$ wi de with 3-ft si dewal I s that served as spl ash guards and i ncorporat ed a go-degree turn at the outl et. The entrance wi dth was $3.9 \mathrm{ft}$ tapering to an outl et wi dth of 2.5 ft. A 2.5-ft I ong by 1.3-ft wi de by 2- $\mathrm{ft}$ deep I i ve box ( $47 \mathrm{gal}$ capaci ty) was wel ded to the dounstreamend of the trap. Perforated sheeting contai ni ng I/8-i nch di aneter, staggered hol es ( $40 \%$ open) was used for part of the floor and I i ve well to di ssi pate $18 \mathrm{cfs}$. Two sets of I/2-i nch thick I ifting brackets were wel ded to the si de walls, and the enti re trap was constructed of 3/16-i nch sol i d al umi num supported on secti ons of I-i nch angl e i ron. Thi s trap will be tested in 1992; testing of the Col d Spri ngs j uveni le fi sh bypass facility will occur in 1993-94.

\section{RESULTS}

\section{Three MI e Fal Is Dam J uveni I e Fi sh Bypass Faci I ity Eval uati on}

Lengths of fish used were si milar for control and treatment fish in al I tests (Fi gures 3 and 4). The sumer steel head used were gradeouts that i ncreased the range of $\mathrm{f} i \mathrm{sh}$ l engt hs test ed. Sumer steel head I engths averaged $150 \mathrm{~mm}$ (fork I ength) and ranged from $35 \mathrm{~mm}$ to $225 \mathrm{~mm}$

I nj ury

Screen I nj ury: Fi sh i nj ury rates of $j$ uveni I e sal noni ds novi ng past the drum screens and into the bypass channel during day and ni ght tests uere not si gni fi cantly greater than control fi sh for spring chi nook sal non ( $F=0.63$, 

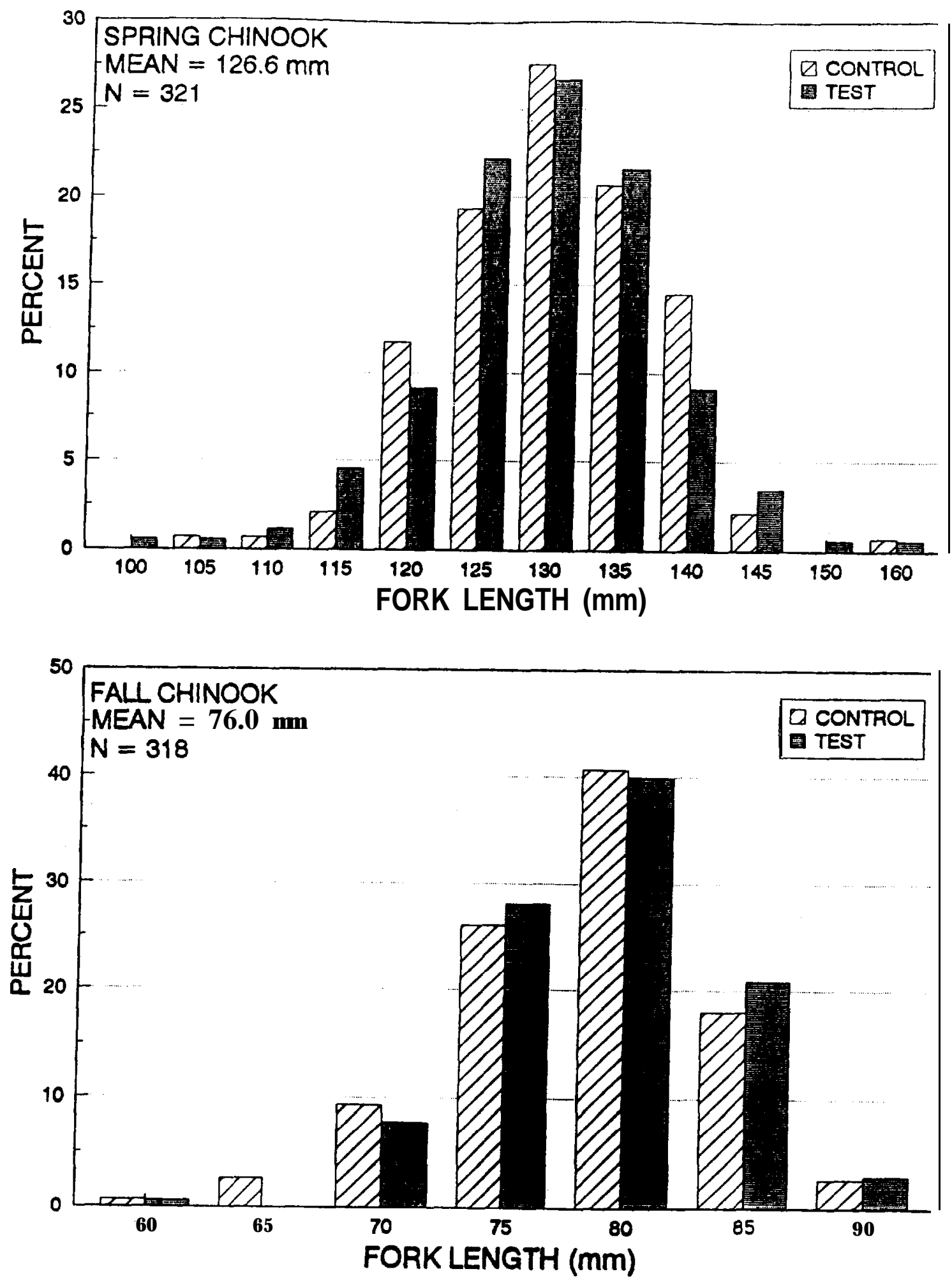

Fi gure 3. Length frequency di stributi on of spring chi nook sal non and fal I chi nook sal non used in inj ury tests at the Wei D Canal facility, Three Mle Fal Is Dam Unati I la Ri ver, Spring 1991. 
$P>0.77)$, fal I chi nook sal non $(F=1.12, P>0.42)$, or summer st eel head $(F=1.91$, $P>0.28$; Tabl e 1). The hi ghest mean net i nj ury percentages were found for spri ng chi nook sal mon daytime control s $(8.7 \%)$ and summer st eel head dayt i me controls (7.2\%). Mst "other" inj uries to fish consisted of eye or head danage.

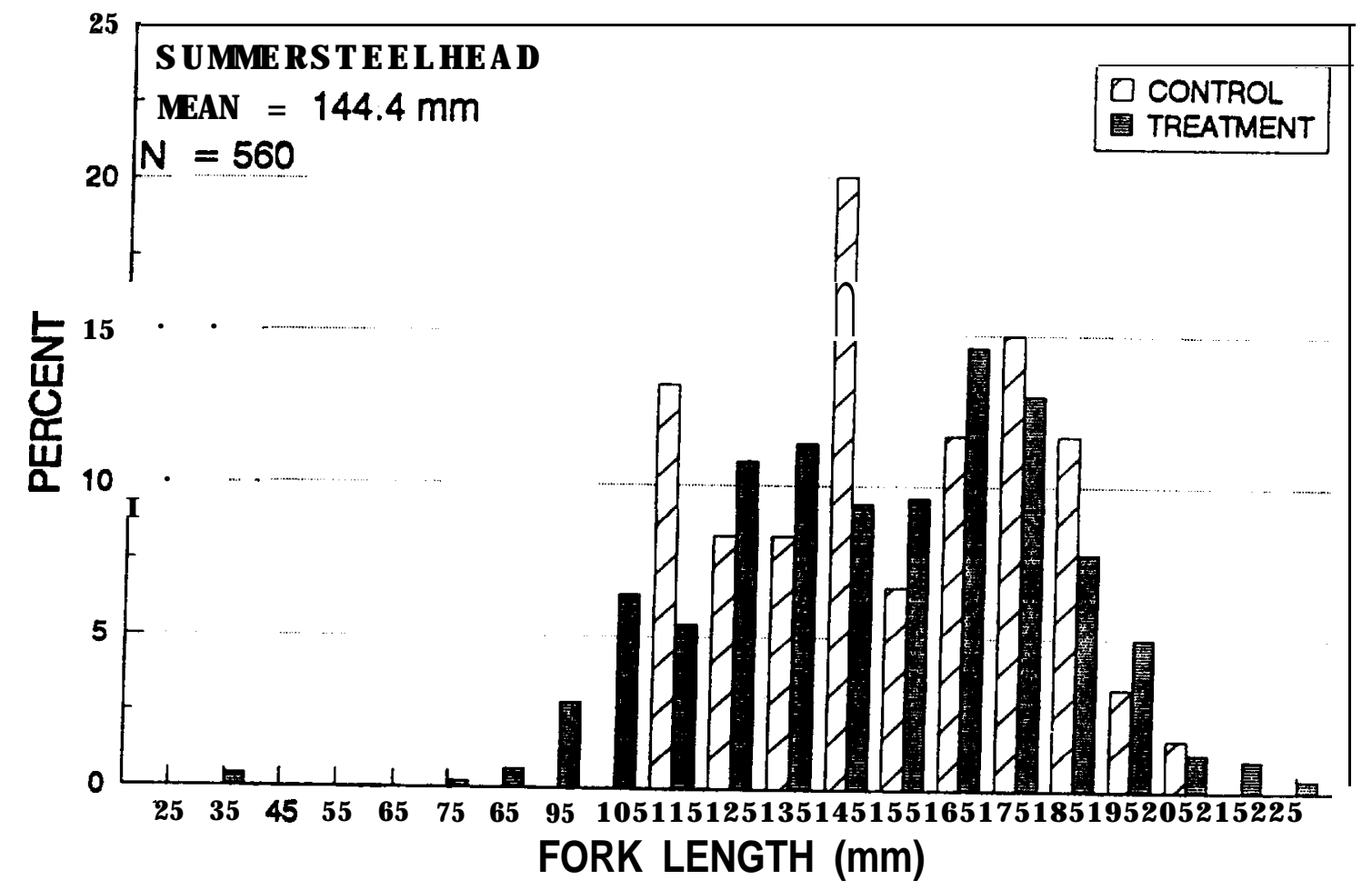

Fi gure 4. Length frequency di stri buti on of sumer steel head used i $n$ i nj ury tests at the VEID Canal fatility, Three MI e Fal Is Dam Unati I l a Ri ver, Spring 1991. 
Table 1. Mean percentages of partl y descal ed, descal ed, and other i nj ured fi sh; net i nj ury rate; and 95\% conf $i$ dence interval s for the WEID Canal screen injury test, Three Mle Fal Is Dam Unatilla River, Spring 1991 (subsample val ues are in parentheses; $N=$ number of test repl i cates).

\begin{tabular}{|c|c|c|c|c|c|c|c|c|c|c|c|}
\hline Speci es & $\begin{array}{c}\text { Control } \\
\text { / test }\end{array}$ & Time & $\begin{array}{l}\text { Nunber } \\
\text { rel eased }\end{array}$ & $\begin{array}{c}\text { Number } \\
\text { recapt ured }\end{array}$ & $\begin{array}{c}\text { Partl y } \\
\text { Descal ed }\end{array}$ & Descal ed & Other & $\begin{array}{r}\text { Net } \\
\text { i nj ury }\end{array}$ & $\frac{95 \% \text { Conf i d }}{\text { ate Lower d }}$ & $\frac{\text { Interval }}{\text { Upper } \mathbf{a}}$ & $\mathrm{N}$ \\
\hline Spring & Control & Day & 809 & 797 & 14.0 & $0.0(0.0)$ & $0.7(0.0)$ & 8.7 & -4.1 & 21.4 & 5 \\
\hline \multirow[t]{3}{*}{ Chi nook } & Test & Day & 799 & 757 & $20.6(20.0)$ & $0.1(0.0)$ & $0.8(1.1)$ & 0.4 & -9.1 & 9.9 & 9 \\
\hline & Control & $\mathbf{N}$ ght & 813 & 811 & $6.9(12.2)$ & $0.0(0.0)$ & $0, \alpha 0,0)$ & -5.4 & -21.9 & 11.0 & 3 \\
\hline & Test & N ght & 807 & 638 & 18.9(26.?) & $0.7(0.0)$ & $0.3(0.0)$ & -6.8 & -16.3 & 2.7 & 9 \\
\hline Fal I & Control & Day & 006 & 803 & 7.2 & $0, \alpha(0,0)$ & O.l(O.0) & 4.3 & 1.5 & 10.1 & 5 \\
\hline \multirow[t]{3}{*}{ Chi nook } & Test & Day & 700 & 513 & 7.2 & $0.0(0.0)$ & $0.0(0.0)$ & 5.9 & 1.4 & 10.5 & 8 \\
\hline & Control & $\mathbf{N}$ ght & 798 & 795 & $3.2 \quad(8.0)$ & $0, \alpha(0,0)$ & $0.0(0.0)$ & -4.9 & -12.3 & 2.6 & 3 \\
\hline & Test & Night & 808 & 715 & 5.6 & $0.0(0,0)$ & $0.2(0.0)$ & 3.7 & -0.6 & 8.0 & 9 \\
\hline Sumer & Control & Day & 324 & 321 & $28.7(21.5)$ & $0.0(0.0)$ & $0.7(0.0)$ & 7.2 & -13.0 & 27.4 & 4 \\
\hline St eel head & Test & Day & 322 & 145 & $35.5(32.1)$ & $0, \propto 0,0)$ & $0, \alpha 0,0)$ & 3.2 & -13.4 & 19.7 & 6 \\
\hline
\end{tabular}


Bypass Outfal I Injury: Condition of fish returning to the river through the bypass pi pe and outfal $\mathrm{I}$ at fl ous of 5 cfs and 25 cfs uas not si gnificantly di fferent than control fi sh for spring chi nook sal non $(F=1.71, P>0.19)$. There was a hi gher probability of a si gnifi cant difference for $f$ al I chi nook sal mon $(F=1.79, P>0.11)$ and summer steel head ( $F=1.86$, Pt $\mathbf{O} \mid \mathbf{O}$; Tabl e 2). However, the maj or source of vari ati on was caused by a day ef fect $(F=4.47$, Pt 0. 02) $f$ or $f$ al I chi nook and a day/ $f$ I ow i nteracti on ( $F=5.42$, Pt $Q$ O1) for steel head, and was not attributable to the bypass outfall. General Iy, the spring chi nook sal non treatment and control groups showed hi gher net i nj ury rates ( range of 12-30\%) than ei ther $f$ al $I$ chi nook sal non or sumer steel head. The percentage of "other" i nj uries for fal I chi nook sal mon were hi gher in this test than for al I ot her tests and speci es, and ranged from $4 \%$ to $13 \%$ The maj ority of these i nj uri es were from predat ors and parasites or were stress-i nduced nortal iti es and were not caused by the testing procedure. These nortalities comprised approxi matel y $\mathbf{8 0 \%}$ of the "ot her" cat egory for both fl ow regi mes, and were a result of hol ding fish for a prol onged period during flooding in I ate May.

Treat nent fish in the outfal I inj ury test were recapt ured wi th I ess success than in the screen inj ury test. Generally, less than $60 \%$ of the rel eased fish were recapt ured. For sumer steel head, the recapt ure percentage uas I ess than $30 \%$

Headgate Injury: Li mited testing suggested that i nj ury rates of $\mathbf{j}$ uveni l e sal moni ds that travel ed past the headgates were not si gnificantly different than control fi sh for spring chi nook sal mon ( $F=1.00, P>0.49)$ or fal I chi nook sal non ( $F=0.50, P>0.85$; Tabl e 3 ).

\section{Leakage}

Drum Screen Leakage: The overal I mean ef $\mathrm{i}$ ci ency rate of fi sh passi ng the drum screens wi thout I eaki ng i nto the canal was esti nat ed at $99.8 \%$ ( Tabl e 4). Esti mated mean efficiency rates for each of the four drum screens showed little variability and ranged from $99.6 \%$ to $99.9 \%$ In additi on, screen ef $\mathrm{f}$ ci ency esti nates for an i ndi vi dual drum screen were si mi ar anong days. Ef $\mathrm{i}$ ci ency. of the bypass col l ecti on system averaged $77.0 \%$ whi I e net ef $\mathrm{f} i$ ci ency averaged $82.3 \%$ of $900 \mathrm{fi}$ sh rel eased upstream of the screens, onl $y$ $6 \mathrm{fi}$ is passed through the screens. Because we observed one rol l over i mpi nged fi sh, we suspected that rol I over may have been the cause for the net capt ure of the other five fish. During the test period, canal fl ous were approxi matel y $50 \%$ of maxi mum desi gn fl ow and ranged from 74.0 cf s to 78.0 cf s.

The I engths of $\mathrm{fi}$ sh rel eased upstream of the screens and caught i $n$ the fyke nets were $60 \mathrm{~mm} 60 \mathrm{~mm} 62 \mathrm{~mm} 64 \mathrm{~mm}$ and $66 \mathrm{~mm}$ These I engt hs were near the average I ength of $f$ al $I$ chi nook sal mon used for both control and treat nent tests (Fi gure 5). 
Table 2. Mean percentages of partly descal ed, descal ed, and other i nj ured fi sh; net i nj ury rate; and 95\% confi dence i nterval s for the VEI D Canal outfal I i nj ury test, Three Mile Fal Is Dam Unatill a Ri ver, Spring 1991 ( subsampl e val ues are in parentheses; $N=$ number of test repl i cates).

\begin{tabular}{|c|c|c|c|c|c|c|c|c|c|c|c|}
\hline Sped es & $\begin{array}{c}\text { Control } \\
\text { / test }\end{array}$ & FI ow & $\begin{array}{l}\text { Number } \\
\text { rel eased }\end{array}$ & $\begin{array}{l}\text { Number } \\
\text { recapt ured }\end{array}$ & $\begin{array}{l}\text { Part I y } \\
\text { descal ed }\end{array}$ & Descal ed & $\boldsymbol{\alpha}$ her & $\begin{array}{l}\text { Net i nj ury } \\
\text { rate }\end{array}$ & $\frac{95 \% \text { Conf i }}{\text { Lower Cl }}$ & $\frac{\text { dence I nterval }}{\text { Upper a }}$ & $\mathbf{N}$ \\
\hline Spri ng & Control & 5 & 589 & 576 & $55.8(36.2)$ & $0.0(0.0)$ & $0.0 \quad(0.0)$ & 19.7 & 3.8 & 35.6 & 7 \\
\hline \multirow[t]{3}{*}{ Chi nook } & I est & 5 & 624 & 355 & $69.1(40.5)$ & $0.4(0.0)$ & $0.4 \quad(0.0)$ & 29.5 & 13.6 & 45.4 & 7 \\
\hline & Control & 25 & 352 & 302 & $48.3(36.8)$ & $0.0(0.0)$ & $0.0(0.0)$ & 11.6 & -9.5 & 32.6 & 4 \\
\hline & Test & 25 & 330 & 173 & $63.9(41.5)$ & $3.5(0.0)$ & $0.9 \quad(0.0)$ & 26.9 & 5.8 & 48.0 & 4 \\
\hline Fal I & Control & 5 & 693 & 673 & $55.0(58.3)$ & $2.1(2.6)$ & $4.0(0.0)$ & 0.2 & -11.5 & 11.9 & 9 \\
\hline \multirow[t]{3}{*}{ Chi nook } & I est & 5 & 748 & 357 & $46.8(61.8)$ & 1. $8(0.0)$ & $8.6(0.0)$ & -4.5 & -16.2 & 7.2 & 9 \\
\hline & Control & 25 & 637 & 601 & $33.1(15.3)$ & $1.3(0.0)$ & $6.6(18.2)$ & 7.3 & -4.4 & 19.0 & 9 \\
\hline & Test & 25 & 688 & 487 & $24.1(17.8)$ & $2.1(0.0)$ & $12.7(17.8)$ & 3.4 & -8.3 & 15.1 & 9 \\
\hline Sumer & Control & 5 & 810 & 823 & $27.7(31.1)$ & O.l(O.0) & $0.0 \quad(0.0)$ & -3.3 & -12.5 & 5.9 & 9 \\
\hline \multirow[t]{3}{*}{ St eel head } & Test & 5 & 538 & 152 & $20.6(28.9)$ & $0.0(0.0)$ & $0.0 \quad(0.0)$ & -8.3 & -17.6 & 0.9 & 9 \\
\hline & Control & 25 & 810 & 723 & $15.8(20.0)$ & $0.0(0.0)$ & $0.0 \quad(0.0)$ & -4.2 & -13.5 & 5.0 & 9 \\
\hline & Test & 25 & 801 & 240 & $32.1(26.7)$ & $0.0(0.0)$ & $0.4 \quad(0.0)$ & 5.8 & -3.4 & 15.0 & 9 \\
\hline
\end{tabular}


Table 3. Mean percentage of partly descal ed, descal ed, other injured fi sh; net-i nj ury rate; and 95\% conf i dence i nterval s for the WEI D Canal headgate i nj ury test, Three MIe Fal Is Dam Unatilla Ri ver, Spri ng 1991 (subsampl e val ues are in parentheses; $N=$ number of test repl i cates).

\begin{tabular}{|c|c|c|c|c|c|c|c|c|c|c|c|}
\hline \multirow[t]{2}{*}{ Speci es } & \multirow{2}{*}{$\begin{array}{c}\text { Cont rol } \\
\text { / test }\end{array}$} & \multirow[t]{2}{*}{ Ti me } & \multirow{2}{*}{$\begin{array}{l}\text { Number } \\
\text { rel eased }\end{array}$} & \multirow{2}{*}{$\begin{array}{l}\text { Nunber } \\
\text { recapt ured }\end{array}$} & \multirow{2}{*}{$\begin{array}{c}\text { Partl y } \\
\text { descal ed }\end{array}$} & \multirow[t]{2}{*}{ Descal ed } & \multirow[t]{2}{*}{ ather } & \multirow{2}{*}{$\begin{array}{c}\text { Net i nj ury } \\
\text { rate }\end{array}$} & \multicolumn{2}{|c|}{ 95\% Confi dence Interval } & \multirow[t]{2}{*}{$\mathbf{N}$} \\
\hline & & & & & & & & & Loner C & Upper C & \\
\hline Spring & Control & Day & 799 & 757 & $20.6(20.0)$ & O.l(O.0) & $0.8(1.1)$ & 0.4 & -9.9 & 10.8 & 9 \\
\hline \multirow[t]{3}{*}{ Chi nook } & Test & Day & 478 & 372 & $5.5(0.0)$ & $0.0(0.0)$ & $0.0(0.0)$ & 5.5 & -12.5 & 23.5 & 3 \\
\hline & Control & N ght & 807 & 638 & $18.9(26.7)$ & $0.7(0.0)$ & $0.3(0.0)$ & -6.8 & -17 & 23.6 & 9 \\
\hline & Test & $\mathbf{N}$ ght & 238 & 204 & $23.1 \quad(0.0)$ & $0.4(0.0)$ & $0.4(0.0)$ & 23.9 & 1.9 & 45.9 & 2 \\
\hline Fal I & Control & Day & 700 & 513 & $7.2(1.3)$ & $0.0(0.0)$ & $0.0(0.0)$ & 5.9 & 0.9 & 10.9 & 8 \\
\hline \multirow[t]{3}{*}{ Chi nook } & Test & Day & 257 & 232 & $10.4 \quad(0.0)$ & $0.0(0.0)$ & $0.4(0.0)$ & 10.8 & 0.7 & 20.9 & 2 \\
\hline & Control & $\mathbf{N}$ ght & 808 & 715 & $5.6 \quad(2.2)$ & $0.0(0.0)$ & $0.2(0.0)$ & 3.7 & -1.0 & 8.4 & 9 \\
\hline & Test & Night & 174 & 152 & $4.3 \quad(0.0)$ & $0.0(0.0)$ & $0.0(0.0)$ & 4.3 & -5.7 & 14.4 & 2 \\
\hline
\end{tabular}


Table 4. Esti mates of drum screen passage effici ency of $f$ al I chi nook sal non fry at the VEI $D$ Canal j uvenile fish bypass facility, Three Mle Falls Dam Unatilla River, April 1991.

\begin{tabular}{|c|c|c|c|c|c|c|c|c|c|c|}
\hline & \multicolumn{2}{|l|}{ Bypass } & \multirow{2}{*}{$\frac{\text { Net }}{\text { Rel eased }}$} & \multirow{2}{*}{ Caught } & \multicolumn{2}{|c|}{ Test Fi sh } & \multirow[b]{2}{*}{$\begin{array}{l}\text { Caught } \\
\text { In bypass }\end{array}$} & \multirow[b]{2}{*}{$\begin{array}{l}\text { Bypass } \\
\text { ef } \mathrm{f} \text { I dency }\end{array}$} & \multirow[b]{2}{*}{$\begin{array}{l}\text { Net } \\
\text { ef fi ci ency }\end{array}$} & \multirow[b]{2}{*}{$\begin{array}{l}\text { Screen } \\
\text { ef fi i ci ency }\end{array}$} \\
\hline & Rel eased1 & Caught & & & Rel eased1 & $\begin{array}{l}\text { Caught } \\
\text { In net }\end{array}$ & & & & \\
\hline \multicolumn{11}{|l|}{ DRUM SCREEN 1} \\
\hline 1 & 300 & 246 & 75 & 69 & 300 & 2 & 158 & 0.820 & 0.920 & 0.989 \\
\hline 2 & 300 & 280 & 75 & 51 & 300 & 0 & 264 & 0.933 & 0.680 & 1.000 \\
\hline 3 & 300 & 167 & 75 & 73 & 300 & 1 & 198 & 0.551 & 0.973 & 01997 \\
\hline TOTAL & 900 & 693 & 225 & 193 & 900 & 3 & 620 & 0.770 & 0.858 & 0.996 \\
\hline \multicolumn{11}{|l|}{ DRUM SCREEN 2} \\
\hline 1 & 300 & 246 & 75 & 70 & 300 & 0 & $1 \%$ & 0.820 & 0.933 & 1. 000 \\
\hline 2 & 300 & 280 & 75 & 70 & 300 & 0 & 264 & 0.933 & 0.933 & 1.000 \\
\hline 3 & 300 & 167 & 75 & 75 & 300 & 1 & 198 & 0.557 & 1. 000 & 0.997 \\
\hline TOTAL & 900 & 693 & 225 & 215 & 900 & 1 & 620 & 0.770 & 0.956 & 0.999 \\
\hline \multicolumn{11}{|c|}{ DRUM SCREEN 3} \\
\hline 1 & 300 & 246 & 75 & 72 & 300 & 0 & 158 & 0.820 & 0.960 & 1.000 \\
\hline 2 & 300 & 280 & 75 & 56 & 300 & 0 & 264 & 0.933 & 0.747 & 1.000 \\
\hline 3 & 300 & 167 & 75 & 41 & 300 & 1 & 198 & 0.557 & 0.547 & 0.995 \\
\hline TOTAL & 900 & 693 & 225 & 169 & 900 & 1 & 620 & 0.770 & 0.751 & 0.998 \\
\hline \multicolumn{11}{|c|}{ DRUM SCREEN 4} \\
\hline 1 & 300 & 246 & 75 & 67 & 300 & 0 & 158, & 0.820 & 0.893 & 1.000 \\
\hline 2 & 300 & 280 & 75 & 71 & 300 & 1 & 264 & 0.933 & 0.947 & 0.996 \\
\hline 3 & 300 & 167 & 75 & 26 & 300 & 0 & 198 & 0.557 & 0.347 & 1.000 \\
\hline TOTAL & 900 & 693 & 225 & 164 & 900 & 1 & 620 & 0.770 & 0.729 & 0.998 \\
\hline GRAND TOTAL & 900 & 693 & 900 & 741 & 900 & 6 & 620 & 0.770 & 0.823 & 0.998 \\
\hline
\end{tabular}

1 A 300-fish group was rel eased upstream of the drum screens (test) and in the bypass channel (control) for each replicate test. 


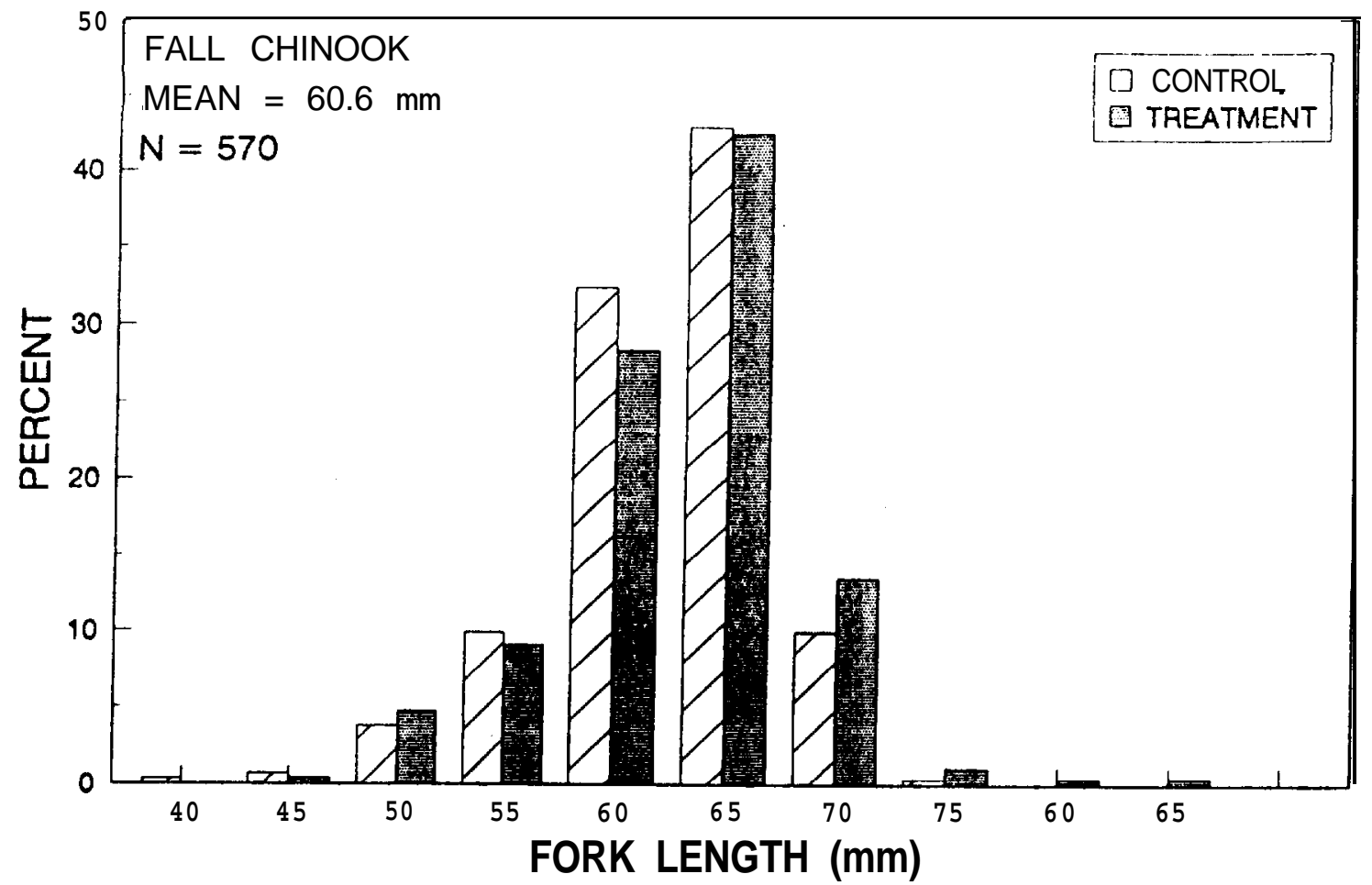

Fi gure 5. Length frequency di stri buti on of $f$ al I chi nook sal mon used in screen I eakage tests at the VEI Canal facility, Three MIe Fal Is Dam Unatilla Ri ver, Spring 1991.

Travel ing Screen Leakage and Fi sh I mpi ngenent: An attempt to capt ure I eakage fish on 9 April was thuarted as the net was torn by the force of the di scharge. The net uas subsequentl y repai red and rei nstal I ed on 15 My duri ng the fall chi nook outmigration. We capt ured one fall chi nook subyearling ( 85 mi) after one hour of sampling. Further sampling was abandoned as the net tore agai $n$ after rei nstal I ation.

During the drum screen I eakage test, we observed $108 \mathrm{f}$ al I chi nook sal non i mpi nged on the secondary travel ing screen (Table 5). These fry were test and control fish from the l eakage test. Sone of the fry were i mpinged in debris piles falling behind the screen. During the drum screen leakage test, the sl ui ce gate to the El-i nch ri ver return drai $n$ pi pe was fully open.

We observed some i mpi ngement on the travel i ng screen of fry rel eased i n the bypass channel when we operated the pumpback pumps and when we opened the ri ver return drai $n$ pi pe. During pumpback pump operation, some fry were observed to "fight" the current pull through the screen and becone temporarily i mpinged before fal I ing of $f$ the screen from the force of the spray water. When the ri ver return drai $n$ pi pe was open, turbul ent condi ti ons exi sted. These condi ti ons vere unf avorable for fry when the pi pe was opened nore than 12 i nches, but were i mproved when the pi pe was opened onl y 9 i nches.

As fal I chi nook sal mon subyearlings migated through the screeni ng facility in May, we observed occasi onal i mpingement on the screen, di scovered 
Tabl e 5. Observati ons of traveling screen i mpi ngenent of $f$ al I chi nook sal non fry at the WEID Canal juveni le fi sh bypass facility, Three MIe Fall s Dam Unatilla Ri ver, Spring 1991 ( ND = no data).

\begin{tabular}{|c|c|c|c|c|c|c|}
\hline Date & Ti ne & $\begin{array}{l}\text { Number of } \\
\text { subyearl i ngs }\end{array}$ & $\begin{array}{c}\text { Number of } \\
\text { fry }\end{array}$ & $\begin{array}{l}\text { Headworks } \\
\text { el evat i on }\end{array}$ & $\begin{array}{l}\text { Sl ui ce } \\
\text { gate }\end{array}$ & Pumps \\
\hline 7 Apr 91 & 2205 & 0 & 20 & 404.0 & open & of $f$ \\
\hline 9 Apr 91 & 0900 & 0 & 87 & 404.1 & open & of $f$ \\
\hline 24 Apr 91 & 1015 & 0 & 1 & 403.9 & cl osed & on \\
\hline 8 May 91 & 0430 & 1 & 0 & 404.0 & cl osed & on \\
\hline 9 May 91 & 1820 & 1 & 0 & 404.4 & cl osed & on \\
\hline 10 May 91 & 0700 & 2 & 0 & 404.4 & cl osed & on \\
\hline 11 May 91 & 0630 & 2 & 0 & 401.0 & cl osed & on \\
\hline 12 Мау 91 & 0730 & 1 & 0 & ND & cl osed & on \\
\hline 13 May 91 & 0640 & 2 & 0 & ND & cl osed & on \\
\hline
\end{tabular}

fi sh in debris pi les behind the screen, and capt ured fish i $n$ a bucket pl aced adj acent to the screen ( Table 5). During the flood in I ate Myy, the sil ui ce gate was fully opened to clear silt in the pump enbayment area. We discovered numer ous organi sns, i ncl udi ng fal I chi nook sal non subyearl i ngs, in the debri s pi les behi nd the secondary screen. I mpi ngenent was not observed during a ful I bypass node when al I bypass fl ow ( 25 cfs) was routed di rectly back to the ri ver with no traveling screen, pump, or sl ui cing operation.

Travel Ti ne

Screen Facility: Fi sh travel ti mes past the drumscreens vari ed by species and ti ne of day. Spring chi nook sal mon travel ti mes showed Iittle di fference bet ween day and ni ght tests wi th approxi matel y 3 hours requi red to capt ure $50 \%$ of the test fi sh and 58-67 hours to catch $95 \%$ of test $\mathrm{fi}$ sh ( Fi gure 6). Fal I chi nook sal mon travel ed past the screens more qui ckly at ni ght wi th $50 \%$ of the fi sh caught i n one hour compared to 5.5 hours for dayti me tests. Summer st eel head noved consi derabl y more sl ow y than spring or fal I chi nook sal mon, requi ring 10.5 hours and 162.0 hours to capt ure $50 \%$ and $95 \%$ of the day test fish, respectivel $y$. No ni ghtti me tests were conducted with summer st eel head.

Lower Bypass: In the 5-cfs test, $25 \%$ of spri ng chi nook sal mon and $27 \%$ of $f$ al I chi nook sal mon noved through the outfal I system at the end of the fi rst hour. Summer steel head moved much nore sl ow y through the out fal I 


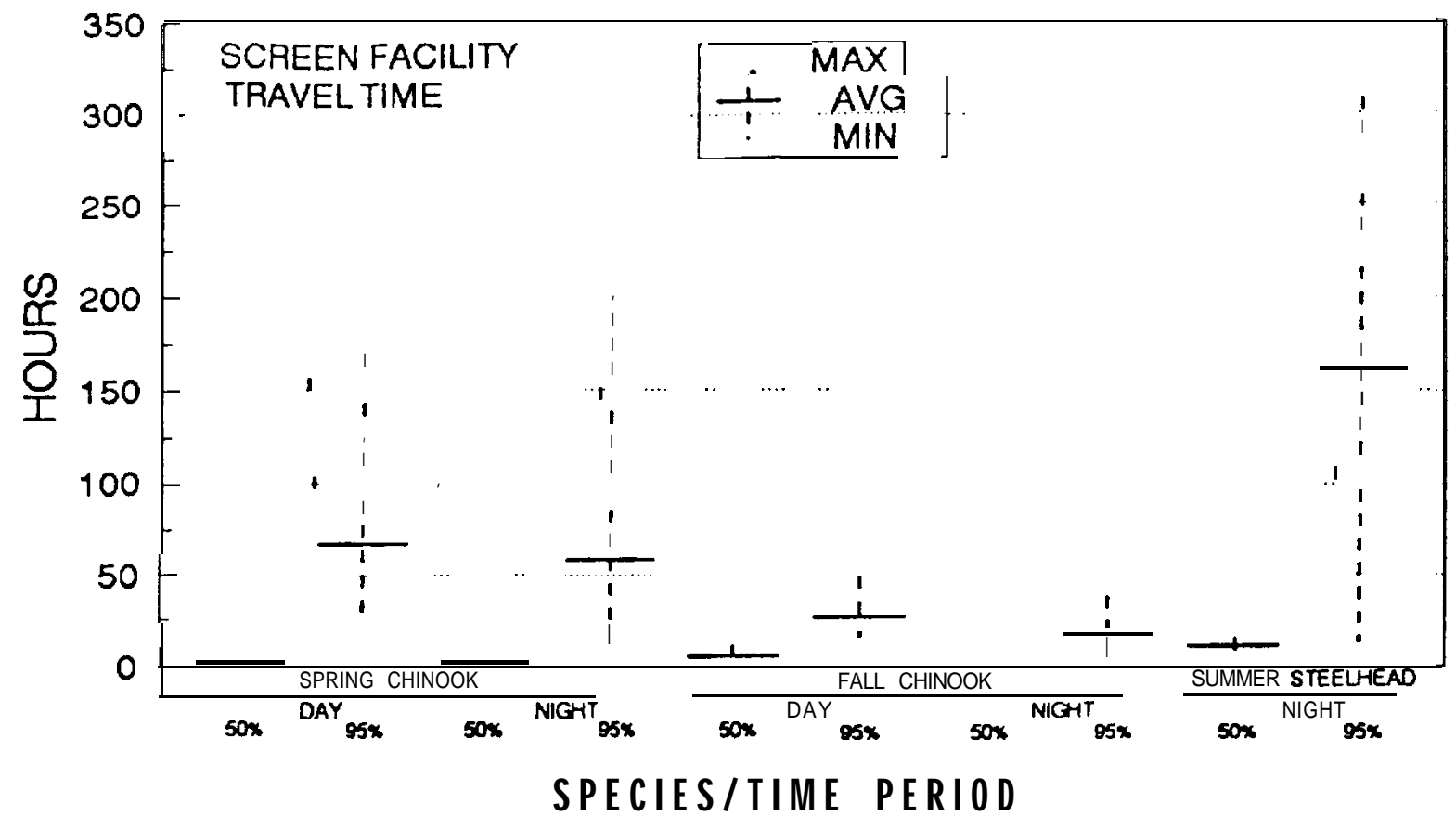

Fi gure 6. Mean number of hours requi red to capt ure $50 \%$ and $95 \%$ of $\mathrm{fi}$ sh rel eased in the screen inj ury test at the VEI Canal facility, Three MIe Fal Is Dam Unati Ila Ri ver, Spring 1991.

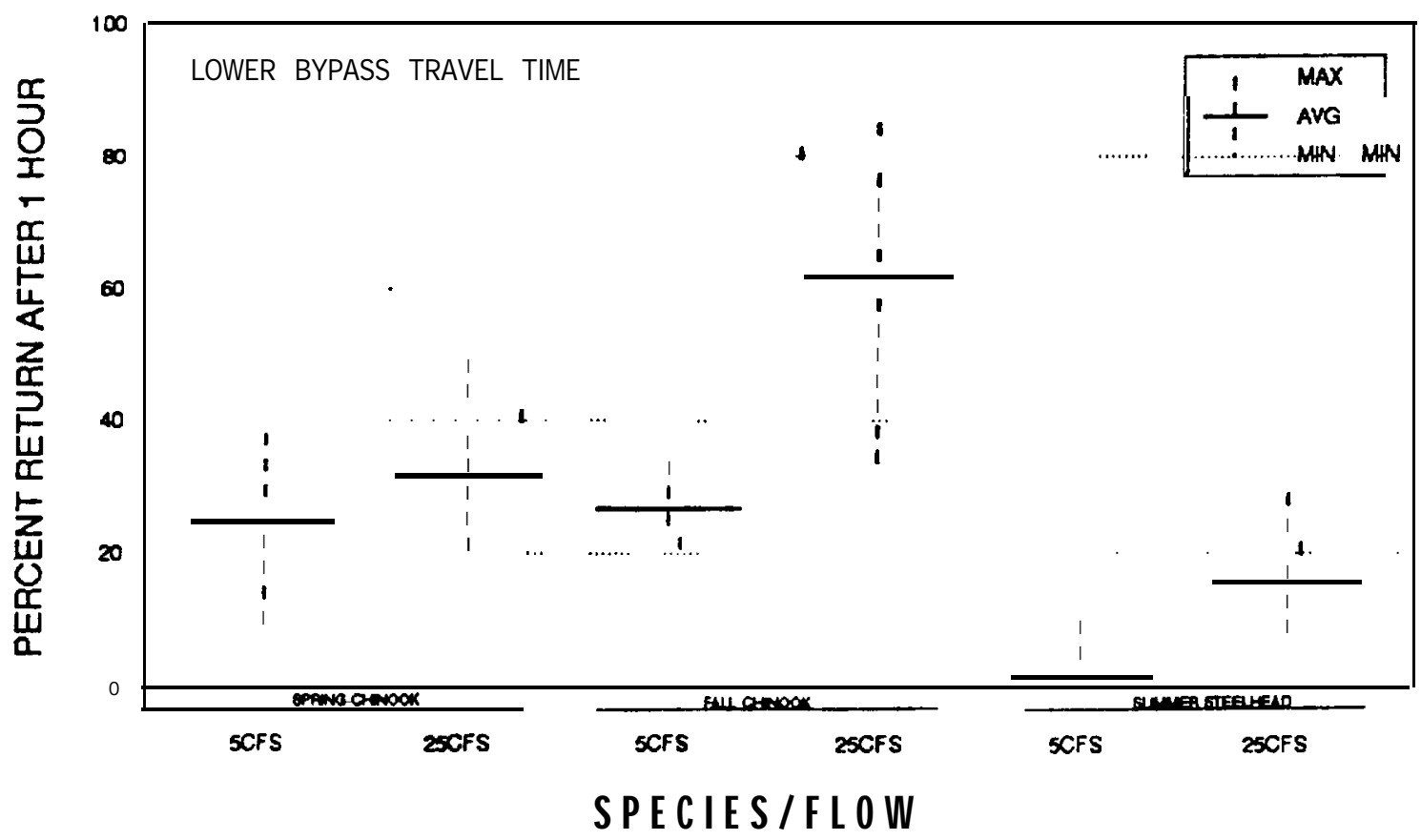

fi gure 7. Percent of rel eased $f i$ sh recapt ured at the end of a $I$-hour sampl $i$ ng peri od during the outfal I inj ury test at the WEID Canal facility, Three MIe Fal Is Dam Unatilla Ri ver, Spring 1991. 
bypass than chi nook sal non wi th $2 \%$ capt ured in the fi rst hour (Fi gure 7 ). Fl ushing the system with 25 cfs 2-4 hours after testing increased the total percentage of spring chi nook sal non capt ured to $56 \%$ Fl ushi ng the system with 25 cf s after the fi rst hour i ncreased capt ure rates for three groups of sumer steel head by $41 \%$ An unknown number of $\mathrm{fi}$ sh ret urned to the ri ver when the net pen was not i n pl ace.

When fl ous in the bypass were 25 cfs, mean capt ure rates were $62 \%$ and $16 \%$ f or fall chi nook sal mon and sumer steel head, respecti vel y. Mean capt ure rate of spring chi nook sal mon after one hour of testing at a bypass fl ow of 25 cf s was $32 \%$

\section{Passage}

Fi sh Bypass Facility: We observed a di sti nct pattern of di urnal passage of hatchery and wi I $\mathbf{j}$ uveni I e sal moni ds through the bypass facil ity at Three M I e Fal Is Dam from upstream I ocati ons i $n$ the Unati l la Ri ver (Fi gure 8). In most cases, movenent through the facility was greatest fromsunrise through sunset. The hi ghest hourl $y$ number of $j$ uveni l e sal moni ds count ed was 1,800 on 24 April and approxi matel y 2,000 on 8 My 1991. Total ri ver-run passage through the fish bypass facility from 5 April to 10 April and from 23 April to 9 May 1991 was 41, $318 \mathrm{fi} h$. Ri ver fl ous duri ng thi s peri od ranged from 400 cfs to 1,000 cfs. I ncl uded in our sample of ri ver-run fi sh on 2 May was a sockeye sal mon neasuring $164 \mathrm{~mm}$ l ong.

1990 Ladder Passage: Juveni I e fi sh counts peaked through the east-bank fi sh I adder from 10 to 13 days after Unati I a Ri ver fI ous reached thei $r$ hi ghest poi nt (Fi gure 9). Duri ng thi s ti me, approxi natel y 30, 000 j uveni I e sal noni ds were observed noving past the vi ewi ng wi ndow The hi ghest dai l y count was 3,787 fish in earl y April and the l owest count was 89 on 4 May. Other di sti nct peaks occurred i n mo- Myy, I ate May, and earl y J une (end of observati on peri od). Fi sh I adder fl ow data during the observati on peri od uas not avai I abl e.

\section{Act i vi ti es at Maxwel I, West I and, and Col d Spri ngs Di versi on Dans}

During testing of the Maxuel I i ncl i ne pl ane bypass trap, we recovered al I 75 subyearli ng chi nook sal mon from rel eases made in the bypass channel. Onl y 7 of the $25 \mathrm{fi}$ sh rel eased i $\mathrm{n}$ front of the $\mathrm{middl}$ e drum screen were recapt ured. Mbst of the fi sh col l ected were in good conditi on, with onl y seven showing signs of partial scal e loss.

Our tests of the nodi fi ed fyke net used at the West l and Dam $j$ uveni I e fi sh hol di ng pond resul ted i $n$ recapt ure rates of $97 \%$ and $94 \%$ for the first and second rel ease groups, respectivel v. Al fi sh in the second group were in good condition. - Ei ghty- $t$ no percent of the fish in the first rel ease group uere in good condition, with si $x$ fi sh showing partial scale loss.

No trap testing was conducted at Cold Springs Dam The desi gn of the incl ined $p l$ ane bypass trap is described in the nethods section. 

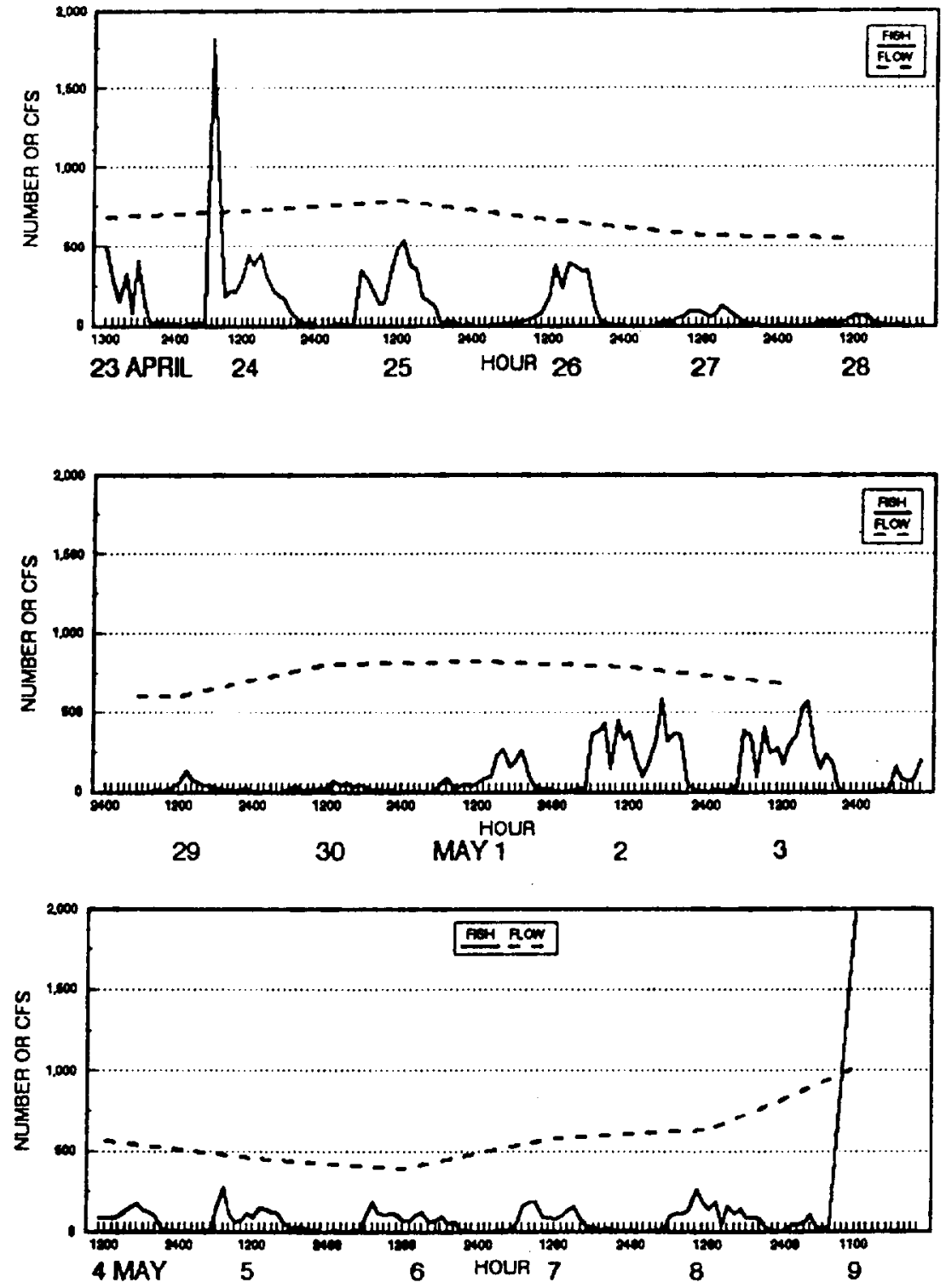

Figure 8. Number of river-run juvenile salmonids passing through the WEID Canal fish bypass facility at Three Mile Falls Dam and Umatilla River flows (cfs) near Umatilla, OR, 23 April - 9 May 1991. 


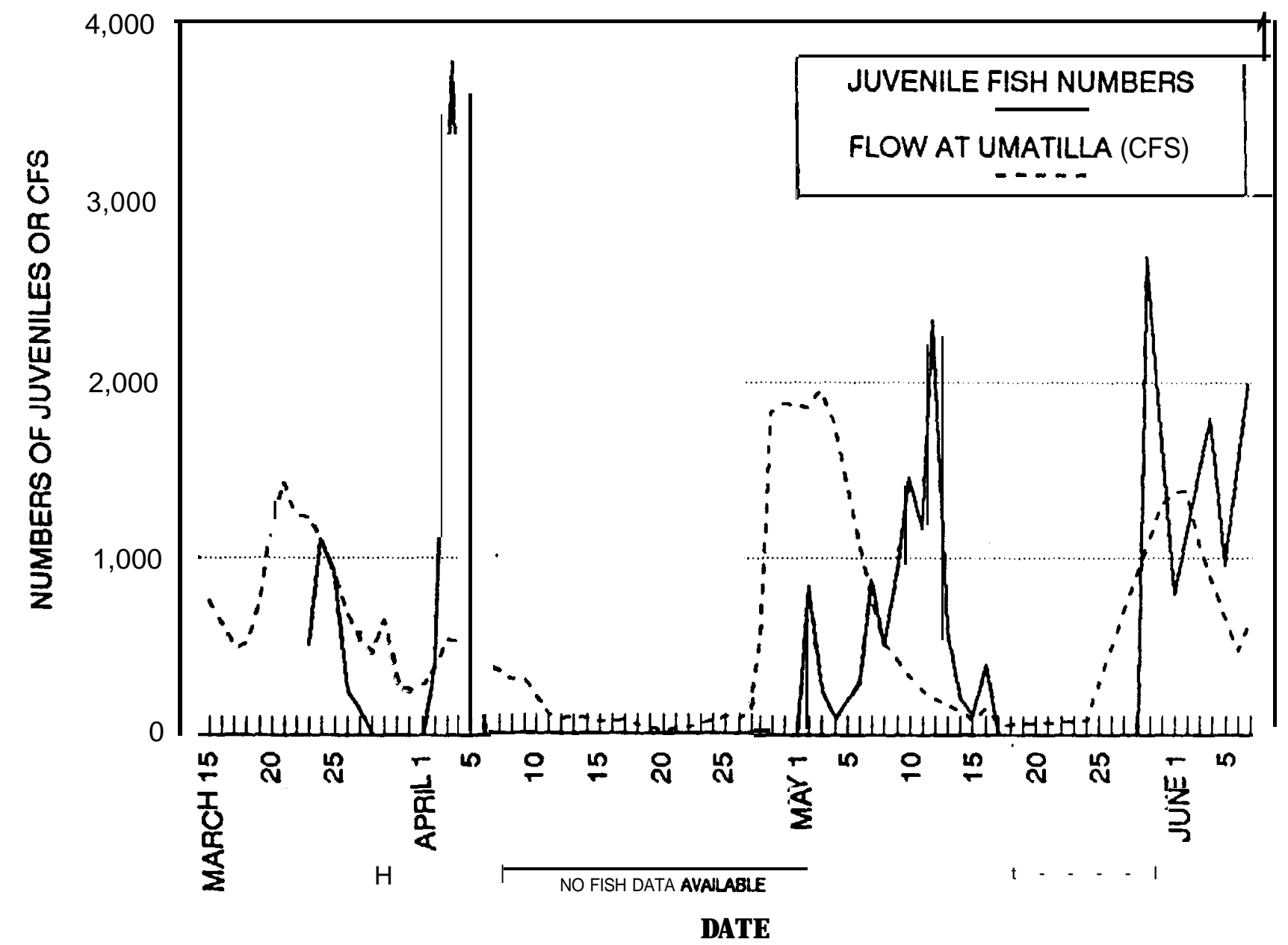

Fi gure 9. Vi deo tape counts of - ri ver- $r$ un $\mathrm{j}$ uveni I e sal moni ds at the east bank $\mathrm{f} i \mathrm{sh} I$ adder at Three MIe Fal Is Dam and Unatilla Ri ver fl ous (cfs) near Unatilla, OR, 15 March - 7 June 1990. 


\section{SCUSSI ON}

Three MIe Fal Is Dam J uveni I e Fi sh Bypass Facility Eval uati on

I nj ury

Snal I sampl e si zes may have confounded some of our results. Wh observed that negati ve net i nj ury rates were obtai ned in the screen i nj ury, bypass outfal I and headgate i nj ury tests, i ndi cating the condi ti on of post-test fi sh was better than pre-test fish. Besi des the effects of snall numbers of fish used to determi ne pre-test condition, these negati ve val ues were al so a resul $t$ of i nherent variabi lity in the descal ing eval uation.

The results of the headgate i nj ury test were al so affected by smal I sample si zes and uncertai nti es about the condi ti on of pre-test fish. Si nce f ew fi sh were avai l abl e, no subsampl es were eval uated for pre-test condi ti on and the assumpti on that thei $r$ condition uas good my not have been val $i d$. Mbre thorough testing wi I be attempted in 1992.

Based on our tests at Three MIe Fal Is Dam and a revi ew of ot her st udi es eval uating anadronous $\mathrm{fi}$ sh passage faciliti es in Northwestern ri vers, it is unl i kel y that any si gnificant i nj ury of fish i $n$ the Unatilla River can be attributed to the VEl Canal fish bypass facility. Mbst of the high inj ury rates that occurred in our tests were part of the sampl ing procedure and were not caused by the facility. The I ow fish i nj ury rates encountered during testing of $f i s h$ passage through the fish bypass facility, past the screens, and through the outfal I pi pe at Three MIe Fal Is Dam uere si milar to results in the Yaki ma Ri ver, Whshi ngton. Eval uati on at Yaki ma Ri ver screeni ng facilities to determ ne passage i nj ury to sal monids showed i nj ury rates of I ess than 5\% (Hosey \& Associ ates 1990b). Si milar tests at other facilities on the Yaki ma Ri ver al so showed I ow i nj ury rates, general I y l ess than $2 \%$ ( Nei tzel et al. 1985, 1987, 1988, 1990a, 1990b).

Leakage

The screeni ng effici ency of the rotary screens at Three MIe Fal Is Dam was high and si milar to the performance of screens at Yaki ma Ri ver faciliti es ( Nei tzel et al. 1988, 1990a, 1990b). The onl y poor passage ef $\mathrm{f} i \mathrm{ci}$ ency reported during that study was at the Westside Ditch ( Neitzel et al. 1990b). In one test, $25 \%$ of ri ver-run chi nook sal mon fry passed through the screens, but the poor screen efficiency was bel i eved to be caused by smal I $f i$ sh size or behavi oral differences. General Iy, nost eval uations of rotary screens have shown screeni ng ef $\mathrm{f} i \mathrm{ci}$ enci es greater than $99 \%$ and summary reports have suggested that angl ed screens are "hi ghl y effective" (Taft 1986) in preventing fi sh I eakage. Conti nued mai nt enance of the VEI D Canal faci I iti es at Three M I e Fal Is Dam emphasi zi ng upkeep of the seal s and adherence to operating criteria, will ensure that j uvenile fi sh are efficiently screened from the canal and returned to the Unatilla Ri ver. 
Travel Ti ne

Si nce canal fl ous were not al tered duri ng the screen i nj ury test and we di d not have detail ed i nf ormation on the movenent of river-run fi sh, we coul d not di rectl y determine if the upper bypass had the potential to del ay fish migration. However, in most cases, at least $50 \%$ of the test fi sh noved through the WEI D Canal screening facility in I ess than 11 hours and it di d not appear that fish novement was del ayed. Our results were si $\mathrm{milar}$ to the range of sal non and steel head travel ti mes reported i n Yaki m Ri ver screen facility eval uati ons (Hosey and Associ ates 1990b; Nei tzel et al . 1985, 1987, 1988, 1990a, 1990b). In both ri ver systens, chi nook sal non were found to nove through the bypass facilities much more qui ckl y than sumer steel head.

Si milarly, we found that sal mon movenent was affected by ti me of day with fish usual I y moving nore rapi dl y at ni ght.

Our anal ysi s of travel ti mes through the I ower bypass duri ng dayl i ght hours i ndi cated that fal I chi nook sal mon and summer steel head noved nore sl ow y through the bypass outfal I pi pe at I ow fl ows than at hi gh fl ows. Mich of the sl ower novenent in our tests was caused by fish hol di ng i $n$ a pocket of water at the end of the bypass pi pe to the outfal I structure. We observed groups of $f i$ sh hol di ng in the out $f$ al I struct ure on several occasi ons, and thi s corroborated observati ons made in 1990 (Knapp and Vhrd 1990). Hosey and Associ ates (1990a) found that for sal moni ds rel eased in the earl y eveni ng, novement through a Yaki ma Ri ver outfal I bypass pi pe uas rapid. However, the fl ow vol une i $n$ the VEI D Canal is general I y smal l er than Yaki na Ri ver canal s and, in conbi nation with ti ne of day variables, nay partial Iy account for the differences observed in our tests. $\mathbf{A}$ though $\mathbf{N}$ etzel et al . $(1985,1987,1988$, 1990a, 1990b) di d not di rectl y test transit ti mes through outfal I pi pes, they reported sl ower fi sh movenent during l ow fl ous at several si tes on the Yaki ma $R i$ ver and suggested that fish could be fl ushed through some facilities. We were able to fl ush fi sh through the bypass system when fl ow was 5 cf s by increasing flow to 25 cfs for a short period of time. Changes in the outfal I desi gn shoul d be consi dered to reduce thi s probl em and pass fi sh more rapi dl y at I ow fl ous. The operati ng gui del $i$ nes at Three M I e Fal I s Dam (USBR 1989) that requi re a 25- cf s bypass fl ow when the drum screens are i nstal I ed and operati ng appear to be val i dated and show the i mportance of provi di ng hi gher bypass fl ows during critical migration periods to qui ckly return fi sh to the ri ver.

It is I i kel y that a wi de range of fish migration behavi ors wi I be observed during this study and the causes for different patterns wil be difficult to ascertain. Several variables are i nvol ved that differ from ri ver to river and could affect passage ti mes, i ncl udi ng size of fi sh, snol ti ng stage, I ocal fl ow condi ti ons, stream hi st ory, and i ndi vi dual characteri sti cs of the facility. Future testing may hel $p$ to describe fish migration through the fish bypass facility and determine if it is any different from migation patterns in the river.

\section{Passage}

It appears that nost $\mathrm{j}$ uveni l e sal moni ds nove through the Unati I a Ri ver and i nto the Col unbi a Ri ver during short wi ndows of opportuni ty. We stopped moni toring fi sh passage in early My 1991 and failed to separate fi sh speci es 
or strai $n$. Therefore, we coul d not determi ne how speci es-specific acti vi ty affected the counts. Fish counts in the WEID Canal fish bypass facility i ncreased in magni tude at daybreak. Duri ng our moni tori ng period, most schedul ed hatchery rel eases in the Unatill a Basi $n$ were coho and chi nook sal mon (CTU R 1990) and we assumed that these speci es compri sed the bul $k$ of dayl $i$ ght migrati on acti vity. Thi s assumpti on was corroborated by data from $\mathrm{Nei} t z e l$ et al. (1987) where coho and chi nook sal non in the Yaki ma Ri ver migrated at daybreak while steel head migratory activity i ncreased at sundown.

A though a $\mathrm{cl}$ ear rel ati onshi $p$ bet ween $\mathrm{fi} h$ passage and $\mathrm{ri}$ ver $\mathrm{fl}$ ow was not establ i shed, it is probable that fl ow uas i mportant. Movenent on 24 Apri l may have been triggered by a peak flow of 1,020 cfs on 15 April. The count on 8 May coi nci ded with fl ous greater than 1,000 cfs, but was not preceded by hi gh fl ow A conbi nati on of fact ors i ncl udi ng ri ver fl ow fi sh si ze and condi $t i$ on, st ocking l ocati ons and dates, and year-to-year seasonal variability will determine the exact timing of fish passage. Si nce a pri mary goal for the basi $n$ is to re-establ i sh natural l y producing sal noni d popul ati ons (NPPC 1989), it is essential to accuratel y document the periods when peak migration occurs to ensure opt i mal operati on of the VEI D Canal fish bypass facility for effici ent fish passage.

\section{Tests}

Some of the tests compl eted in $1991 \mathrm{will}$ be repeated in 1992 to i mprove on i nconcl usi ve or uncompl eted tests. Several aspects of the eval uation can be i mproved to i ncrease the conf i dence in our test results. An accurate anal ysis of fish inj ury caused by the facility depends on starting the tests with fi sh in good condition. In several cases, a signi fi cant porti on of fi sh used i 1991 uere i $n$ poor condi ti on pri or to testi ng. In addi ti on, an attempt will be made to ensure nore uni form si ze di stri buti on wi thi $n$ each test speci es group. It is probable that the wi de si ze range of sumer steel head used added to the variability of the test results.

We wi I I mpl enent an i mproved stati sti cal desi gn i n 1992 to provi de nore bal ance between treatment and control tests. Occasi onal I y in 1991, we pool ed control s thereby reducing the sample si zes for testing. We will al so attempt to subsample a l arger number of fi sh to determine the pre-test condition. The appearance of negati ve numbers i $n$ the computation of the net-i nj ury rate may have been the result of subsampling a small number of fish. Our plans for 1992 at Three MIe Fal Is Dam are described in our statement of uork (APPEND X A). Wbrk at Maxuel I Dam will be di sconti nued because of pl ans by the Bureau of Recl amation to cease operation of this facility in the near fut ure.

\section{Operati onal and Struct ural Problens at Three M I e Fal Is Dam}

\section{Sampl i ng Equi pnent}

We experi enced great difficulty in our efforts to renove and depl oy the bypass channel sampl i ng equi pnent (i ncl i ned screen and separat or sampl e box) during our eval uation. The equi pment was cumbersone to maneuver and diffi cul t to al i gn properly. We al so had difficulty changing froma ful l bypass node to a sampling node when fish were in the bypass channel. Unl ess fi sh were 
removed from the bypass channel bet ween the wei $r$ gate and orifice pl ate bef ore the i ncl i ned screen was depl oyed, they woul d becone trapped underneath the i ncl i ned screen and be ul ti nately fl ushed through the auxiliary infl ow system Occasi onal I y thi s occurred and created bl ockages in the auxi I i ary i nf I ow Ii nes. To effecti vel y drai $n$ and remove fi sh fromthis area, a stopl og was i nstal l ed downstream of the travel ing screen and $f i$ sh were netted out.

There is no easy and ef $\mathrm{fi}$ ci ent means to depl oy the i ncl i ned screen, nor are operating i nstructions i ncl uded in the desi gner's operating criteri a for the facility (USBR 1989). We inserted an eye bolt into the top edge of the screen to permi I ifting and maneuvering with the crane. The i ncli ned screen needed to be in the correct I ocation and proper position when I overed to attach it to the support frame. The si de and bott om rubber seal s tended to curl under the screen during depl oyment and extra effort was requi red to keep them properly al i gned. fut ure operat ors of this equi pment wi I need to be auare of the problens to ensure efficient and effective use.

J uveni I e sal moni ds cont i nued to escape into the bypass downuel I i nst ead of bei ng di verted i nto the sampl ing trappi ng area during the sampl ing node. A though I oss of $f i$ sh was reduced wi th the $i$ nstal I at i on of a $E-i$ nch neoprene barrier at the downstream end of the separat or in 1990 (Knapp and Whrd 1990), sone fish were still l ost when fish entered the separator too rapidly or at a perpendi cul ar ori entati on to the separat or bars. Cont i nued I osses may requi re that the separat or be redesi gned or that another modi fied barri er devi ce be installed. These I osses pri marily occurred when water fl ous and canal water l evel s were normal or sonewhat hi gh. At I ow ri ver fl ous and a headuorks water el evati on bel ow 404. $1 \mathrm{ft}$, water and $\mathrm{fi}$ sh trickl e ont o the separat or and $\mathrm{fi}$ sh I oss at the end is not a problem The concern in this scenario is the need to prevent water l oss through the separator top perforated pl ate, a recomendati on that was made previ ousl y (Knapp and Vhrd 1990).

Duri ng sampl ing, we observed that $\mathrm{fi}$ sh became trapped behi nd a perforated pl ate on the back si de of the sample box, Closer i nspecti on reveal ed that a gap exi sted al ong the edge of the transfer chute that led from the separat or sample box to the transfer fl une. Thi s gap probabl y resulted from bypass i nf I ow water pressure di storting the separat or assenbl y and I eavi ng a gap on the upstream edge. Fi sh di verted i nto the transf er fl une apparentl y swam back up the current, I ocated the si de gap, and suam behi nd the perforat ed pl ate, onl y to becone trapped and die. This problem uas nost pronounced duri ng the fal I chi nook outmigration because of the snal l average size of the chi nook sal non subyearli ings.

We documented several ot her fi sh-rel at ed struct ural probl ens that wi I requi re annual i nspecti on and mi nt enance to correct or prevent, i ncl udi ng an unsecured rubber seal at the bott om of the i ncli ned screen. The pri mary concern is I eakage or escape of $f i$ sh, reduci ng di versi on ef fecti veness. The fact that one fal I chi nook sal non subyearling ( $86 \mathrm{~mm} / \mathrm{ong}$ ) was capt ured i $\mathrm{n}$ the fyke net at the terminus of the river return drai $n$ pi pe indi cates possi ble travel ing screen I eakage. Apparently operati onal and structural probl ens pose the greatest threat to smal I fal I chi nook sal mon subyearlings. 
Travel ing Screen

Fi sh i mpi ngement on the secondary screen (travel ing screen) duri ng the sampl ing mode was the pri mary bi ol ogi cal probl em observed at the facility. During the sampling node, 20 cfs is taken through the travel ing screen and pumped into the canal or returned to the river through the 21-i nch di anet er ri ver return pi peline. The renai ni ng 5 cfs passes through a bypass orifice $\mathrm{pl}$ ate at the downstream end of the secondary screen. When the sl ui ce gate to the river return pi pel i ne was opened rather than the pumps operating, ue observed i ncreased i mpi ngenent rates of fry.

Contri buti ing factors to thi s i mpi ngement probl em nay have i ncl uded the presence of a hydraulical ly i nefficient transition of a 25- cf s fl ow from the bypass entrance to a 5-cfs fl ow through the orifice plate. Because of an abrupt moment um l oss upstream of the orifice pl ate, an unstable fl ow condi ti on at the screen face was created that resulted in surging and i nst ant aneous hi gh vel ocity hot spots at the screen face. Depending on the degree of sl ui ce gate openi ng, the fl ow through the travel ing screen when excess bypass fl ow is bei ng returned to the river can exceed 30 cf s (I etter dated 10 October 1991 from WS. Rai ney, Nati onal Mari ne Fi sheri es Servi ce, to J. Marcotte, Bonnevi I l e Power Admi ni strati on).

As $\mathrm{fi}$ sh became i mpi nged on the screen, they uoul d "rol l over" to the back si de of the screen because of i nsuffici ent spray water in the i mpi ngenent l ocation. Our observations were that i mpi ngenent occurred enti rel y in the northeast corner of the rotating screen, an obvi ous "hot spot" area that di d not recei ve sufficient fl ushing with spray water. Apparently frequent pl ugging of the terminal spray nozzle on the spray water bar occurred because of river debris.

There exi sts a need to remedy the i mpi ngenent probl em with struct ural or operati onal modi fications. A recommendat i on has been made to operate onl y one pump to reduce the bypass entrance fl ow from $25 \mathrm{cfs}$ to $15 \mathrm{cfs}$, and reduce fl ow through the secondary screen by $50 \%$ This approach woul d I i kel y reduce surging near the secondary screen and al l ow nore effici ent hydraul ic conditions for fish passing through the bypass orifice plate. This could be i mpl enented if 15 cf s provides enough fl ow to efficiently ret urn fish to the river. In addition, it was recommended that use of the sl ui ce gate shoul d be I i mited to short peri ods during dayl i ght hours, when $j$ uvenile passage rates are presumed to be at the l owest l evel s, and throttled back as i mpi ngenent is observed ( l etter dated 10 October 1991 from W S. Rai ney, Nati onal Mari ne Fi sheri es Servi ce, to J ay Marcotte, Bonnevi Ile Power Admi ni stration). In I i ght of our findings on diel passage of river-run fish in which passage rates were hi qhest duri ng dayl i ght hours, a ni ghtti ne operation of the sl ui ce gate may be preferable. Thi s would be particul arly i mportant during fut ure high uater events, when heavy river si It l oads and sedi ment ati on probl ens at the facility nould requi re intensi ve sl ui cing efforts.

\section{Operating Criteria}

Fl uct uati ons in headuorks water I evel above or bel ow the normal operating criteria of $404.1 \mathrm{ft}$ are a concern because they affect bypass operations. At l evel s greater than $404.1 \mathrm{ft}$, fi sh and debris may rol over at the drum 
screens. These si tuati ons may occur when river fl ow ri ses suddenl $y$, as duri ng the fl ood in I ate May 1991 . Mre than $80 \%$ of the drum screens were submerged duri ng this hi gh fl ow event. At l evel s l ess than 404.1 ft (403.9), sampl ing efforts are hampered because $\mathrm{min}$ mal water fl ows across the top of the i ncl i ned screen. Thi s probl em was reported previ ousl y (Knapp and Whrd 1990) and may be a concern when trapping and haul i ng j uveni l e sal noni ds duri ng I ow ri ver fl ow

\section{Acti vi ti es at Maxuel $I$, West I and, and Col d Spri ngs Di versi on Dans}

We encountered very few problens during testing of traps at Maxuel I and Westl and dans. At Maxuel I Dam the pri mary operati onal probl em encountered was the formti on of a backwash eddy in the front corners of the trap that stranded fish entering this area. It was necessary to push these fi sh into the mai $n$ water fl ow for recapt ure i $n$ the I i ve box. We subsequentl y nodifi ed the trap by riveting al umi num pl ates di agonal $\mathrm{y}$ across the front corners to prevent strandi ng of $\mathrm{fish}$. We al so recovered l ess than $30 \%$ of subyearl ing chi nook sal mon rel eased i $n$ front of the middl e drum screen. These fi sh were observed school ing in the screen forebay. At Westl and Dam the net appeared to work wel $I$ and the onl y modi fi cati on made was the i ncl usi on of addi ti onal fl oatati on materi al on the I i ve box. Our $p l$ ans for 1992 at Westl and Dam are described i n our 1992 statement of nork ( APPENDI X A). 


\section{RECOMMENDATI ONS}

Based on our efforts during the eval uation, we recomend the fol I ow ing i mprovements to ensure safe and ef fective fi sh passage through the $j$ uveni $\mathrm{l} e$ fi sh bypass facility at the VEI D Canal.

1. The headgates and checkgates to the VEI D Canal shoul d be aut onated to ensure proper water I evel el evations in the forebay and headuorks area at al I ti mes. A normal operating water surface el evation of $404.1 \mathrm{ft}$ at the drum screens shoul d be mai nt ai ned whenever possi bl e to ensure effecti ve operation of the facility components.

2. A I equi pnent seal s shoul d be annual I y i nspected and regul arl y repl aced to prevent fi sh l oss. Thi s woul d i ncl ude the secondary travel ing screen, the pri mary drum screens, and bypass channel sampl i ng equi pment. Appar ent l y, struct ural defici enci es pose the greatest threat to smal I fi sh (fry and subyearl i ngs).

3. The operating criteria for the left-bank fish facilities at Three Mle Fal I s Dam shoul d be anended to i ncl ude speci fic gui del i nes for operat ing the sl ui ce gate to the 21-i nch river return drai $n$ pi pe, and for depl oying sampl ing equi pment. We recommend that the sl ui ce gate not be operated duri ng dayl i ght hours when fish passage is most preval ent. Operators need to be made auare that thei $r$ actions may cause i nj ury to and l oss of $f i$ sh.

4. A nechani sm to control the amount of water el i minated through the fi sh separat or perforated $\mathrm{pl}$ ate is needed duri ng l ow fl ow peri ods, parti cul arl y when trapping or sampling is occurring unattended. Fi sh can be stranded on the perforated $p l$ ate, and in the sample box and transfer fl ume if little water reaches these areas.

5. In concurrence wi th the Nati onal Mari ne Fi sheri es Servi ce, we recomend that onl y one pump be operated during modes other than a ful I bypass mode to reduce the bypass entrance fl ow from 25 cfs to $15 \mathrm{cfs}$. Thi s would reduce by hal $f$ the fl ow through the secondary screen and decrease surgi ng in the separati on chanber.

6. The operating criteria for the VEI D Canal, as anended, should be foll owed in the effort to protect fish that move through the system Operating gui del i nes and criteri a should be nade readi ly avai l able for al I users of the facility. Staff gauges should be installed at al I critical l ocations to determine compl $i$ ance with the operating criteria.

7. A means to prevent fish from I eavi ng the transfer chute and ent ering behi nd the back perforated $\mathrm{pl}$ ate in the sample box shoul d be i nvestigated. 


\section{TERATURE CI TED}

Boyce, R. R. 1986. A comprehensi ve pl an for rehabi litation of anadronous fi sh stocks i $n$ the Unatill a Ri ver basi $n$. Fi nal report to Bonnevi l le Power Admi ni strati on by Oregon Department of Fi sh and $V^{*} I$ dl i fe. Cont ract Nb. DE-A179-848P18008. Port I and, Oregon.

Conf ederated Tri bes of the Unati I I a I ndi an Reservati on and Oregon Department of Fi sh and Vild ife. 1990. Unatilla basin artificial fi sh producti on pl an. October 1990 :- Sept enber 1991. M ssi on, Oregon.

Hosey \& Associ ates. 1988. Eval uation of the ef $f$ ecti veness of $f i s h$ protection facilities. Chandl er facility eval uation. Report by Hosey and Associ ates Engi neering Company for the U. S. Bur eau of Recl anati on.

Hosey \& Associ ates. 1989. Eval uation of the effecti veness of $\mathrm{fi}$ sh protection facilities. Roza facility eval uation. Report by Hosey \& Associ ates Engi neering Company and Fi sh Managenent Consul tants for the U.S. Bur eau of Recl anation.

Hosey \& Associ ates. 1990a. Eval uati on of ef fecti veness of $\mathrm{fi}$ sh protection facilities. East on facility eval uation. Report by Hosey \& Associ ates Engi neeri ng Company and Fi sh Management Consul tants for the U.S. Bur eau of Recl anati on.

Hosey \& Associ ates. 1990b. Eval uati on of ef $\mathrm{fect} i$ veness of $\mathrm{fi}$ sh protecti on facilities. Eval uati on of Chandl er, Col umbi a, Roza and East on screeni ng facilities, compl eti on report. Report by Hosey \& Associ at es Engi neering, Company and Fi sh Managenent Consul tants for the U. S. Bur eau of Recl amation.

Knapp, S. M, and D. L. Mard. 1990. Pages 4- 32 i n A A N gro, edi tor. Eval uat $i$ on of $j$ uveni $I$ e $f i$ sh bypass and adul $t$ f $i$ sh passage faciliti es at Three MIe Fal Is Dam Unatilla Ri ver. Annual Progress Report to Bonnevi I l e Power Admi ni strati on, Portl and, Oregon.

Neitzel, D. A, C. S. Abernethy, E. W Lusty, and L. A Prohammer. 1985. A fi sheri es eval uati on of the Sunnysi de Canal fi sh screening facility, spring 1985. Prepared by the Pacific Northuest Laborat ory, Ri chl and, Whshi ngt on, for the Di vi si on of Fi sh and V*I dl i fe, Bonnevi I l e Power Admi ni strati on, Portl and, Oregon.

Nei tzel, D. A , C. S. Abernethy, and E. W Lusty. 1987. A fi sheri es eval uati on of the Ri chl and and Toppeni sh/Sat us Canal fi sh screening facilities; spring 1986. Prepared by the Pacific Northwest Laborat ory, Ri chl and, Washi ngt on, for the Di vi si on of Fi sh and Vil I d i f e, Bonnevi I l e Power Admi ni strati on, Portl and, Oregon.

Nei tzel, D. A , C. S. Abernethy, E. W Lusty, and S. J. Wampl er. 1988. A fi sheries eval uation of the Ri chl and and Wato Canal fi sh screening facilities, spring 1987. Prepared by the Pacific Nort huest Laborat ory, Ri chl and, Whshi ngt on, for the Di vi si on of Fi sh and Vill dl ife, Bonnevi I l e Power Admi ni strati on, Portl and, Oregon. 
Nei tzel, D. A , C. S. Abernethy, and E. W Lusty. 1990a. A fi sheri es eval uati on of the Toppeni sh Creek, Whato, and Sunnysi de fi sh screening facilities, spring 1988. Prepared by the Pacific Nort hwest Laborat ory, Ri chl and, Whshi ngt on, for the Di vi si on of Fi sh and Vild ife, Bonnevill e Power Admi ni stration, Portl and, Oregon.

Nei tzel, D. A, C. S. Abernethy, and G A Martenson. 1990b. A fi sheri es eval uati on of the Westsi de Ditch and Toun Canal fi sh screening facilities, spring 1989. Prepared by the Pacific Northuest Laborat ory, Ri chl and, Whshi ngton, for the Di vi si on of Fi sh and V"I dl i fe, Bonnevi I l e Power Admi ni stration, Portl and, Oregon.

NPPC (Northuest Power PI anning Council). 1987. Col unbi a Ri ver basi n fi sh and wildl ife program (as anended). Northwest Power PI anni ng Council, Port I and, Oregon.

NPPC (Northwest Power PI anni ng Council). 1989. Unati I l a Hatchery master pl an. Nort hwest Power PI anni ng Counci I, Port l and, Oregon.

SAS I nsti tute Inc. 1990. SAS I anguage: reference, versi on 6, fi rst edition. Cary, North Carol i na.

Taf $t$, E. P. 1986. Assessment of downst ream nigrant fi sh protection technol ogi es for hydroel ectric appl i cation. Research Proj ect 2694- 1, Stone \& Webster Engi neering Corporati on, Bost on, Massachusetts.

USBR ( U. S. Bureau of Recl anati on). 1989. Prel i mi nary desi gner's operati ng criteria. Three Mle Fal Is Di versi on Dam l ef $t$ bank $f i$ sh faciliti es, Unatill a Proj ect, Oregon. Denver, Col orado. 


\author{
APPEND X A \\ 1992 Pl anned Activities for the \\ Unati I a Ri ver Passage St udy
}

\title{
Goal s and Obj ecti ves
}

Our study goal is to eval uate the passage of $\mathbf{j}$ uveni I e sal moni ds at di versi ons in the Unati I la Ri ver and make recomendations to i mprove passage, if appl i cable. We will investigate effects facility operation and structure have on j uveni $I$ e $f i$ sh and thei $r$ abi I i ty to bypass di versi ons. Our efforts from 1989 through $1990 \mathrm{i}$ ncl uded modi fi cati on and operati on of the $\mathrm{j}$ uveni l e bypass system i $n$ the VEI D Canal at Three MIe Fal I s Dam to obtai $n$ prel i mi nary i nf or nati on on facility effici ency and juveni le sal monid condi ti on and passage. In 1991, we prepared for and conducted a ful I-scal e eval uati on of $j$ uveni l e passage at the VEI D Canal facility, and desi gned and fabri cated some fi sh capt ure faci lities for Mexuel I, Uest I and,-and Col d Spri ngs dans to enhance our abi ll i ty to conduct fut ure eval uations of these facilities.

The three obj ecti ves for the 1991-92 project period are to (1) determine if probl ens exi st with passage of summer steel head, and spring and $f$ al $I$ races of chi nook sal mon through the headgates and the bypass system in the VEI D Canal and through the east-bank adult fi sh I adder at Three M I e Fal Is Dam (2) conduct a f easi bi lity study at Westl and Dam to ensure readi ness for a 1993 eval uati on; and (3) determ ne if fl ow characteristics at defi ned l ocations in the screeni ng facilities at Three Mle Fal Is and Westl and dans neet desi gn speci fi cati ons. Eval uati on efforts at Maxuel I Dam will be abandoned due to pl anned termination of canal and facility operation in the near fut ure as a resul $t$ of Phase II compl eti on of the FI ow Enhancenent Proj ect.

Def i ni ti ons

Eval uati on efforts wil be accompl i shed in the context of specific task paraneters. For clarity in the purpose of this study, these paraneters are defined as fol lous.

Passage: The movenent of $\mathrm{fi}$ sh through the components of a fi shuay or di versi on screening facility from thei $r$ entrances to thei $r$ ri ver ret urn outl ets. Passage wi I al so refer to "I eakage" of j uveni l e fi sh through or over a screeni ng struct ure.

Passage Success: The ability of $f i$ sh to pass or navi gate through a fi shway or di versi on bypass system and be returned to the river wi thout i ncurring inj ury or nortal ity, or experi encing i mpedi ments to nat ural novenent or, for $j$ uveni I e fi sh, I oss into the canal.

Di versi on Rate: The cuml at i ve percent of rel eased $j$ uveni l e fi sh that enter a di versi on system 
Travel Ti me: Average ti ne for rel eased fi sh to travel froma rel ease poi nt to a recovery poi nt.

I nj ury: Fi sh i ncurring body i nj uri es or scal e I oss duri ng passage froma rel ease poi nt to a recovery poi nt.

Hortal ity: Fi sh not survi ving passage froma rel ease poi nt to a recovery poi nt as a result of injuries.

Docunent: To observe presence or absence.

Esti mate: To determine percent of fish i $\mathrm{n}$ a rel ease and recovery test.

Test Fi sh: Fi sh used in a mark and recapt ure study.

Ri ver-Run Fi sh: Non-test fi sh that are part of the adul $t$ fish migration or j uveni I e fi sh out mi grati on.

Eval uati on: The synt hesi s of esti mates, observati ons, and determi nations to determine the synergi stic effects of a systemin the overal l context of passage success.

Speci fi cal I y, we wi II repeat several i nj ury and I eakage tests and take addi ti onal vel ocity measurements at Three MI e Fal I s Dam because we vere unable to sati sf actori l y compl ete these tests in 1990 and 1991 . We wi I al so (1) document passage and esti mate $i$ nj ury of $j$ uveni l e fi sh novi ng through the eastbank I adder at Three MIe Fal Is Dam (2) take vel ocity measurenents at specific l ocati ons in the Westl and Canal screeni ng facility, (3) operate the West l and Canal faci I ity bypass and associ ated structures, and (4) desi gn and fabri cate al I col l ecti on traps to carry out an eval uation at Westl and Dam i n 1993.

We wil esti mate inj ury and nortality of fish associ ated with the Three MIe Fal Is Dam passage faciliti es by rel easi ng groups of marked $f i$ sh at vari ous I ocati ons i $n$ the I adder and di versi on canal, recapt uri ng them at downstream sites, and inspecting them for nortality, descaling or other inj ury. We wil make correspondi ng rel eases in the recapt ure faci lities to assess and compare i nj ury caused by the collection and handling process. We will esti mate travel ti me by determining the difference between ti me of rel ease and ti ne of recapt ure. We wili esti mate di versi on rates by the proportion of fish entering a di versi on system fromthe total number of $\mathrm{fi}$ sh rel eased in front of the headgates. We wil esti mate fi sh I oss into the canal through the travel ing screen by rel easi ng groups of $\mathrm{fi}$ sh upstream from the screens and recapt uri ng them in a fyke net set downstream from the screen. We will determine if vel ocity patterns adhere to desi gn criteria by measuring approach and sueep vel ociti es in front of the drum and travel ing screens, and at the entrances to the bypass channel and the fish ret urn during various phases of operation.

J uveni l e fi sh to be used i $n$ the eval uations wi I be hel d at hatchery or accl i mation facilities and haul ed to study si tes prior to the tests for freeze branding or dyei ng and accl i mation. Fal I chi nook fry wi I be dyed. Freezebranded fi sh wi I be hel d in separate contai ners approxi natel y 48 hours before rel ease. 
A survey of vel ocity patterns at the Three MIe Fal Is and Westl and screeni ng facilities will be accompli shed usi ng an el ectromagnetic water current meter. We wi II pattern our surveys after those perforned by previ ous researchers (Abernethy et al. 1989, 1990). We will take measurenents during I ow normal and hi gh di versi on fl ous to ascertai $n$ adherence to screening facility desi gn criteria.

Obj ecti ves

Cbj ecti ves and corresponding tasks for 1991-92 are as fol l ous.

Obj ecti ve 1 Det ermi ne the passage success of sumer st eel head, and spring and fall races of chi nook sal mon through the bypass system in the VEI D Canal and the east-bank fi sh I adder at Three MI e Fal Is Dam

Task 1. 1 Esti mate travel ti me, i nj ury and mortality of sumer steel head associ ated wi th the drum screens at desi gn fl ow

To esti mate travel ti ne, i nj ury and nortal ity associ ated with the drum screens, we wi I rel ease repl i cate groups of heal thy, f reeze- branded $f i$ sh upstream of the screens; recapt ure them at the bypass collection facility; and examine the fish for descaling and ot her i nj uri es (t reat ment). We will al so rel ease repl i cate groups of heal thy, freeze-branded $f i$ sh di rectly i nto the col l ection facility to al l ow us to eval uate i nj ury caused by the col l ecti on and exami nat i on process (control). We will conduct tests during the day and at ni ght and wi I repeat each day and ni ght test on three di fferent dates at desi gn fl ow - Each treat ment and control, day and ni ght rel ease will consi st of three I oo-fi sh repl i cate groups. We will exami ne a $30 \%$ subsample from each repl i cate group for condi ti on pri or to rel ease to ascertai $n$ pre-rel ease condition. These subsample fi sh will not be returned to thei $r$ groups. We will determine travel ti me from the rel ease l ocati on upstream of the screens to the collection facility by esti mating the ti ne to recapt ure $50 \%$ ( nedi an travel ti me) and $95 \%$ of the rel eased test fish.

We wi I use the method of Neitzel et al. (1985) to determi ne fi sh condition. The condi ti on of recapt ured fi sh wi I be categorized as heal thy, parti al Iy descal ed, descal ed (or dead), and i nj ured (Hosey \& Associ ates 1988). We will use anal ysi s of vari ance (ANOVA) to test.t he hypothesis that the rel ative condition of control and treat nent fish in the various tests are equal in al I rel eases. Sources of variation tested in the ANOVA will be (1) treatment versus control, and (2) ti me of day (day or ni ght). We will transform the data as appropri ate to neet the assumptions of ANOVA For purposes of anal ysi s, we 
wi I cal cul ate pre-test condi ti on (from subsampl es) and post-test condi ti on (from control or treat ment fish) of fi sh observed as percentages of recapt ured i nj ured fi sh (the sum of partly descal ed, descal ed, and other i nj ured

fish). We will then cal cul ate net inj ury rate as the difference between pre-test and post-test condition. We will compute a $95 \%$ conf $i$ dence interval about the difference in the net i nj ury rate bet ween corresponding treatment and control groups.

Rati onal e: We were not able to sati sfactori ly compl ete the screen i nj ury test for summer steel head in 1991 because of acci dental l oss of test and control fish.

Products: We will compute mean and $95 \%$ conf $i$ dence interval s for the total proportion of sumer steel head . inj ured, descal ed or kill ed during. passage past the screens. We will use anal ysi s of variance to test for si gni ficant difference in inj ury rates between the respective treatment and control groups. We will conpute travel ti ne for $50 \%$ and $\mathbf{9 5 \%}$ of the recapt ured test fi sh.

Schedul e: Test preparation wi II be compl eted during wi nter 1991-92. Fi sh will be procured, branded and rel eased during Apri I 1992. Data anal ysi s and a report of results will be compl eted by 30 Septenber, 1992 (Appendi x Tabl e AI).

Task 1. 2 Esti mate travel . ti me, i nj ury and mortal ity of fal I chi nook subyearlings associ ated with the bypass pi pe and bypass outfal I at a 5-cfs and 25-cfs outfal I fl ow

To esti mate i nj ury and nortality rates associ ated with the bypass pi pe and bypass outfall, we will release repl $i$ cate groups of heal thy, freeze- branded $f i$ sh at the entrance of the bypass pi pe, recapt ure them at the bypass outfal $\mathrm{I}$ to the river, and exam ne the fish for descal ing and ot her i nj uri es (treat ment). A fl oating net pen placed di rectly beneath the outfall will be used to recapt ure treat nent fish. We wi I al so rel ease repl i cate groups of heal thy, freeze-branded fish di rectly into the fl oating net pen to all ow us to eval uate i nj ury caused by the col l ecti on and handl ing process (control). We will repeat each test on three different dates and at flous of 5 cfs and 25 cfs. Each treat ment and control, 5-cfs and 25-cfs rel ease will consist of three 100-fish groups. We will exami ne a $30 \%$ subsample from each treatment and control repl i cate subgroup for condition pri or to rel ease to ascertai $n$ pre-rel ease condition. These subsample fish wi I not be returned to thei $r$ groups. We wi I determine if fish novenent from the bypass downuel I to 
the bypass outfal I is i mpai red by computing the percentage of fi sh recapt ured after a one-hour interval for 5-cf s and 25-cf s bypass fl ous.

We wi II exami ne fi sh for conditi on and anal yze the data the same as di scussed i n Task 1.1 .

Rati onal e: We conducted the bypass pi pe and bypass outfal I i nj ury test in 1991 with subpar fal I chi nook subyearlings due to a protracted hol ding peri od caused by fl ooding and hi gh fl ous.

Product s: he will compute mean and $95 \%$ conf $i$ dence i nterval s for the total proporti on of $f$ al I chi nook subyearlings i nj ured, descal ed or killed during passage from the entrance to the bypass pi pe to the bypass outfall at the VEID Canal facility. We will use anal ysi s of vari ance to test for si gni ficant difference i $n$ i nj ury rates bet ween the respecti ve treat ment and control groups. We will compute the percentage of test fish recapt ured after a one-hour i nt erval at operating condi ti ons of 5- cf $s$ and 25- cf $s$ bypass fl ow to determine if fi sh novenent through the I over bypass syst em i s i mpai red.

Schedul e: Test preparati on wi l be compl et ed during wi nter 1991-92. Fi sh will be procured, branded and rel eased during May 1992. Data anal ysi s and a report of resul ts will be compl eted by 30 Septenber, 1992.

Task 1. 3 Esti mate di versi on rate, travel ti me, i nj ury, and nortal ity of Sumer steel head, and spring and $f$ al I races of chi nook sal mon associ ated wi th operati ng the canal headgates at I ess than ful I headgate openi ng.

To esti mate i nj ury and mortal ity associ ated wi th passage through' a reduced headgate openi ng, we will rel ease groups of heal thy, f reeze-branded $f i$ sh upst ream of the three headgates; recapt ure them at the col l ecti on facility; and examine themfor descaling or other inj ury (treat ment). We will set the headgate openi ngs at approxi natel y $1 \mathrm{ft}$ (I/3 of normal operati on openi ng). We will foll ow the same procedures outli ned i n Task 1.1 to compl ete the test for each species or race of fi sh. Travel ti me will be esti mated from the rel ease l ocati on upstream of the headgates to the coll ecti on facility, as in Tasks 1.1 and 1.2. We will stati stically compare mean travel ti ne with travel ti me esti nated in Task 1.1 for sumer steel head. Di versi on rate wi I . be esti mated from the cumul ati ve percentage of rel eased fish entering the canal and arriving at the collection facility over ti me. We will examine fi sh for condition and anal yze the data as di scussed i n Task 1.1 . 
Rati onal e: We observed vel oci ty i ncreases caused by reduced openi ng si ze of the headgates. Subnergence of a reduced entrance openi ng my subject fish to non-favorable hydraulics and encounters with debris piles.

Products: We will compute mean and 95\% conf $\mathrm{i}$ dence interval s for the proporti on of sumer steel head, spring chi nook and fal I chi nook subyearlings i nj ured, descal ed or ki I l ed duri ng di versi on through reduced headgate openi ngs i nto the VEI D Canal. We wi I use anal ysi s of vari ance to test for si gnificant difference in injury rates between treatment and control groups. We will compute travel ti me for $\mathbf{5 0 \%}$ and' $\mathbf{9 5 \%}$ of the recapt ure test fish to determine if fi sh di versi on is i mpeded by a reducti on in the headgate openi ng.

Schedul e: Fish will be procured, branded and rel eased during Apri I and May 1992. Data anal ysi s and a report of results will be compl eted by 30 Septenber, 1992.

Task 1. 4 Document passage ( I eakage) and i mpi ngement of fal I chi nook fry and subyearli ngs associ ated with the travel ing screen when operating pumpback pumps in tandem or i ndi vi dual I y and varyi ng gate openi ngs of the ri ver return drai $n$ pi pe.

To document the extent of passage around and over the travel ing screen i $n$ the VEI D Canal of smal ler-sized fi sh we wil i instal I a fyke net at the terminus of the 21-inch di aneter river return drai $n$ pi pe. The drai $n$ pi pe wi l be in operation during the sampling mode when the travel ing screen is functioni ng, but the pumpback pumps are not. A I fish that pass through or over the operating travel ing screen wi I eventual ly be di verted $t$ hrough the drai $n$ pi pe and recapt ured in the fyke net. We will count fi sh i mpinged on the travel ing screen or fish that have l eaked around the screen and into the fyke net at varying openi ngs of the river return drai $n$ pi pe. When ri ver fl ow drops and bypass f I ow needs to be di verted back to the canal, the drai $n$ pi pe will be closed and the pumpback pumps will be put i nto operation. We will count fi sh i mpi nged on the travel ing screen when operati ng the pumpback pumps in tandem or i ndi vi dual I y. Leakage cannot be detected due to the i nabi I ity to recapt ure fish during pump operation. To make counts and observations, we wi l rel ease groups of fall chi nook fry upstream of the travel ing screen. We will al so observe l eakage and i mingement during tests using fall chi nook subyearlings and during the subyearling out migration.

Rati onal e: I n 1991, we observed sone i mpi ngenent of fal I chi nook fry and subyearlings on the travel ing screen in the VEI D Canal during pumpback pump operations and at 
varying level s of river return drai $n$ pi pe gate openi ngs. We col l ected a fal I chi nook subyearling i $n$ a fyke net pl aced at the terminus of the river return drai $n$ pi pe.

Products: We will document the presence or absence of I eakage or i mpi ngement of fal I chi nook fry and subyearlings around or on the travel ing screen associ ated with the operation of the pumpback pumps in varying conbi nations and with a full and throttled ri ver ret urn drai $n$ pi pe gate openi ng.

Schedul e: Fabri cati on of a new ri ver ret urn drai $\mathbf{n}$ pi pe f yke net will be compl eted during the fall of 1991 . We wi I observe I eakage and i mpi ngenent of $f$ al I chi nook fry in early Apri I and of fall chi nook subyearlings in Myy. A report of our observations will be compl et ed by 30 Septenber, 1992.

Task 1. 5 Esti mate i nj ury of spring chi nook sal non at varying degrees of turbul ence in the bypass downuel I caused by changes in fl ow and water I evel.

To esti mate inj ury of spring chi nook in the bypass downuel I, we will rel ease fi sh at the wei $r$ crest in the-bypass channel and recapt ure them at the bypass outfal I in the fl oating net pen. We will vary the bypass channel fl ow and water hei ght in the downuel I to test i nj ury l evel s agai nst varyi ng turbul ence condi ti ons in the downuel I. We wi l al so rel ease fi sh di rectl y i n the 24-i nch bypass pi pe to serve as our control.' he wi l performsimilar test procedures, exami ne fi sh and anal yze data as di scussed i n Task 1.1.

Rati onal e: General observati ons of poor condi ti on of spring chi nook in the bypass pi pe and outfal l test conducted i $\mathbf{n} 1991$ i ndi cate that turbul ence in the bypass downuel I may be causi ng i nj ury.

Products: We will compute mean and $95 \%$ conf $i$ dence interval s for the proportion of spring chi nook that are i nj ured or descal ed during passage into the downuel I at varyi ng degrees of turbul ence caused by changes i $n$ fl ow and water level. Wh will determi ne if i nj ury rates of treatment fish are si gnifi cantly different from control fish using ANOVA

Schedul e: See-Appendi x Tabl e A I.

Task 1. 6 Docunent passage, i nj ury and mortality of summer steel head, and spring and fal I races of chi nook sal non associ ated with the east-bank fish I adder during the j uveni l e out mi gration. 
To document the extent of passage of out mi grating $j$ uveni I e sal moni ds through the east-bank fish I adder, and possible inj ury and mortality associ ated with this passage, we will enunerate snol ts passing by the fi shway vi ewi ng wi ndow from vi deo tapes of adul $t$ passage recorded by CTUR. We will al so vi sual ly observe movenent of $j$ uvenil e fi sh through the vari ous components of the I adder, i ncl udi ng the attraction water wei $r$ and the entrance pool and other di ff users. We will collect and brand good-condi ti on fi sh at the bypass facility, rel ease them in the upper portions of the I adder, and col I ect them at the base of the I adder to esti mate inj ury incurred as fish pass through the I adder structure. Fi sh condition will be ascertai ned as described i n previ ous tasks. We will rel ease fish in our capt ure facilities to eval uate inj ury caused by collection and handl i ng ( cont rol).

Rati onal e: We observed $\mathrm{j}$ uveni l e fi sh passage through the east-bank I adder i n 1990 and recorded passage counts from vi deo tapes of adul $t$ passage $i \mathrm{n}$ ' the spring of 1990. Rel ati ve passage rates through the east-bank I adder appeared to be si milar to passage through the west-bank j uvenile fiish bypass facility during the same ti me period, indi cating that snol ts use the I adder as a means to bypass the dam even when the bypass is in operation.

Products: We will document numbers of $j$ uveni l e sumer steel head, and spring and fall races of chi nook sal mon passing through the east-bank adult fish I adder at Three M I e Fal Is Dam in 1991 and 1992. We wil esti mate i nj ury l evel s of $j$ uveni l e sal moni ds passi ng through the I adder to prel iminarily ascertai $n$ if I adder passage occurs in an effective and non-i nj urous manner.

Schedul e: We will conduct vi sual observations and test rel eases at the east-bank. I adder during the springsumer out mi grati on from mid-Apri l to mid-J une 1992. We will read 1991 adult passage vi deo tapes in the fal I and wi nter of 1991-92.

Objecti ve 2 Ensure ef $\mathrm{f} i$ ci ent operati on of the $j$ uvenile sal moni d bypass and collecti on system in the canal at Westl and Di versi on Dam and desi gn, fabricate, and test al I necessary capture facilities in preparation for passage eval uati on acti vi ti es, i n 1993.

Tasks 2. 1 Operate the bypass and hol di ng pond facilities at West I and Dam

We will operate the bypass and hol di ng pond faciliti es i n concert with i rrigation di strict and trap and haul personnel to familiarize oursel ves with the overal I operation and ensure that the facilities operate as 
desi gned. We will test operate al I systens and st ruct ures, i ncl udi ng gates, pumps, fi sh separat or, bypass i nf I ow and outf I ow the juveni I e hol di ng pond and associ ated sampl ing system and the drum and travel ing screens. A I aspects of the day-to-day operation of the facility will be monitored. We will test operate the bypass facility when $j$ uveni le sal noni ds are migrating past West I and Dam We will test operate the j uveni I e col I ecti on and hol di ng system during trap and haul operati ons when ri ver fl ow is I ow

Rati onal e: We were not able to gai $\mathbf{n}$ a thorough understandi ng of faci I ity operati on through extensi ve hands- on experi ence i $\mathbf{n} 1991$ because of I i mited staff and ti me constraints. Ability to conduct a successf ul eval uati on i s cont i ngent on operati onal expertise due to the compl exity and uni queness of the West I and Canal system and j uveni I e faci I i ty.

Products: We pl an to gai $n$ thorough knowl edge of facility operati on at Westl and Dam and assurance of an effici ent and properl y functioning system that wi l be ready to eval uate after 1 October, 1992.

Schedul e: We will familiarize oursel ves with the system through hands- on operati on duri ng the 1992 spri ng, sumer, and fal $\mathrm{l}$ uveni l e outmi gration. A report of activities and findings will be completed by 30 Sept enber, 1992.

Task 2. 2 Desi gn, fabri cate and test capt ure facilities necessary for conducting eval uati on activi ti es i n 1993 at West I and Dam

We will desi gn and fabri cate col lection facilities to be used at the bypass outl et, downstream of the drum and travel ing screens, and in the bypass channel in the West I and Canal. These capt ure faci I ities will be used i n vari ous i nj ury and I eakage tests i n 1993. Traps wi I be si milar in desi gn to those used i $n$ eval uations at Three Mle Fal Is Dam

We will test operate the col lection facilities during the mi grati on peri od of j uveni le sal moni ds. We will rel ease and recapt ure marked fi sh to eval uate the ef $i$ ci ency of the traps in capt uring the naj ority of fish, and to ensure that the trapping process does not result in excess i nj ury or nortal ity. A nodified fyke net wi th fl oating Ii ve box has been fabricated and tested and will be used for capturing test fi sh in the juveni l e hol di ng pond. We wil I collect samples of river-run fish in these traps to determine if i nj ury or mortality I evel s are obvi ously 
hi gh.

Rati onal e: We were not able to sat i sfact or i ly compl ete bypass channel and bypass out l et capt ure facility design and fabrication due to structural complexiti es of the bypass system and "fl ood-caused" al teration of the river channel at the outl et.

Products: We wi l gai $n$ the abi l ity to effici entl y and ef fecti vel y col l ect fi sh at defi ned I ocations i n the canal and bypass system at Westl and Dam and to conduct tests to determine passage success of $j$ uveni l e sal moni ds through the bypass system in the Westl and Canal after 1 October, 1992. We will document hi gh l evel s of i nj ury or nortality of river-run fish.

Schedul e: Traps will be desi gned and fabricated during spring 1992. Traps will be test operated duri ng sumer and fal I 1992. A report of results will be compl et ed by 30 Septenber, 1992.

Objective 3 Determine if vel ocities at defined l ocations in the bypass systens at Three MIe Fal Is and Westl and dans neet desi gn criteria.

Task 3. 1 Measure approach vel ocity in the bypass channel, and approach and sweep vel ociti es through the travel ing screen at Three MIe Fal Is Dam

We will use an el ectronagnetic water current meter and record vel ociti es (f eet per second) at $0.2 \% \quad 0.5 \%$ and $0.8 \%$ of water depth. Measurements will be taken at centerli ne and at the upstream and dounstream edges of the traveling screen, and at the entrance to the bypass channel. The probe will be positioned parallel to the screen poi nting upstream for recordi ng sueepi ng vel ociti es and poi nted perpendi cul arly auay from the screen for recording approach vel ocities. We will measure vel ocities at the traveling screen and at the entrance to the bypass channel during operation of the pumpback pump i $n$ tandem or i ndi vi dual $\mathbf{y}$ and at varyi ng gate openi ngs of the river return drai $n$ pi pe. We wi I al so measure vel ociti es in the bypass channel during a 25- cf s fl ow Headuork el evati on, canal fl ow and operating conditions, water depth, and ti ne to neasure will be noted.

Products: We will determine if vel ocity patterns meet desi gn criteria at the bypass channel entrance and at defi ned I ocations i $n$ front of the travel ing screen during varying operati ons of pumpback pumps and river return drai $n$ pi pe gate i $n$ the VEI Canal at Three Mle Falls Dam 
Schedul e: We will measure vel ocity patterns at defi ned I ocati ons i n the VEI D Canal during April and Nyy 1992.

Task 3. 2 Measure approach and sweep vel ocity at the drum screens, travel ing screens, and entrance to the bypass channel at Wést l and Dam

We will foll ow the same procedure as described in Task 3. 1. We will take measurenents during I ow nedi um and hi gh canal fl ous to determine if vel ocity patterns neet criteria at al I operations. Drum screen vel ocity measurements will be taken cl ose to the screens and at the centerline peri neter of the screens. Headworks el evati on, canal fl ow and operati ng condi ti ons, drum screen subnerged dept $h$, and travel ing screen operations will be recorded.

Products: We will determine if vel ocity patterns neet desi gn criteria at the drum screens, travel ing screens and at the entrance to the bypass channel at West I and Dam at I ow nedi um and hi gh canal fl ous.

Schedul e: We will measure vel ocity patterns at defi ned I ocati ons in the Westl and Canal from Apri I to J une 1992. 
Abernethy, C-S., D. A Neitzel, and E. W Lusty. 1989. Vel ocity measurenents at si $x$ fi sh screeni ng faciliti es in the Yaki ma Ri ver basi $n$, Wishi ngt on, summer 1988. Prepared by the Paci fic Nort hwest Laborat ory, Ri chl and, Whshi ngt on, for the Di vi si on of Fi sh and Wild i fe, Bonneville Power Admi ni stration, Portl and, Oregon.

Abernethy, C. S., D. A Nei tzel, and E. W Lusty. 1990. Vel ocity measurenents at three fish screening facilities in the Yaki ma Ri ver basi $n$, Wishi ngt on, summer 1989. Prepared by the Pacific Northuest Laborat ory, Ri chl and, Wishi ngt on, for the Di vi si on of Fi sh and Vild i fe, Bonneville Power Admi ni stration, Portl and, Oregon.

Hosey and Associ ates. 1988. Eval uati on of ef fecti veness of $\mathrm{fi}$ sh protection facilities. Chandl er facility eval uation. Report by Hosey \& Associ ates Engi neeri ng Company for the U.S. Bur eau of Recl anation.

Nei tzel, D. A , C. S. Abernethy, E. W Lusty, and L. A Prohamer. 1985. A fi sheri es eval uati on of the Sunnysi de Canal $f i$ sh screening facility, spring 1985. Prepared by the Pacific Northwest Laborat ory, Ri chl and, Whshi ngt on, for the Di vi si on of Fi sh and Vild ife, Bonnevi I le Power Administration, Portl and, Oregon. 
Appendi x Table Al. Acti vity schedul e summary for eval uati ng $\mathbf{j}$ uveni l e sal moni d passage facilities at Three MIe Falls and Westl and dans, Oct ober 1991 through Sept enber 1992 .

\section{Mont h}

Activity at Nov Dec Jan Feb Mar Apr May J un Jul Aug Sep

\section{Gear}

Preparati on

St udy Design-

Task 1.1

Task 1.2

Task 1.3

Task 1. 4

Task 1.5

Task 1.6

Task 2. 1

Task 2.2

Task 3. 1

Task 3.2

Data Anal ysi s

Report Witing

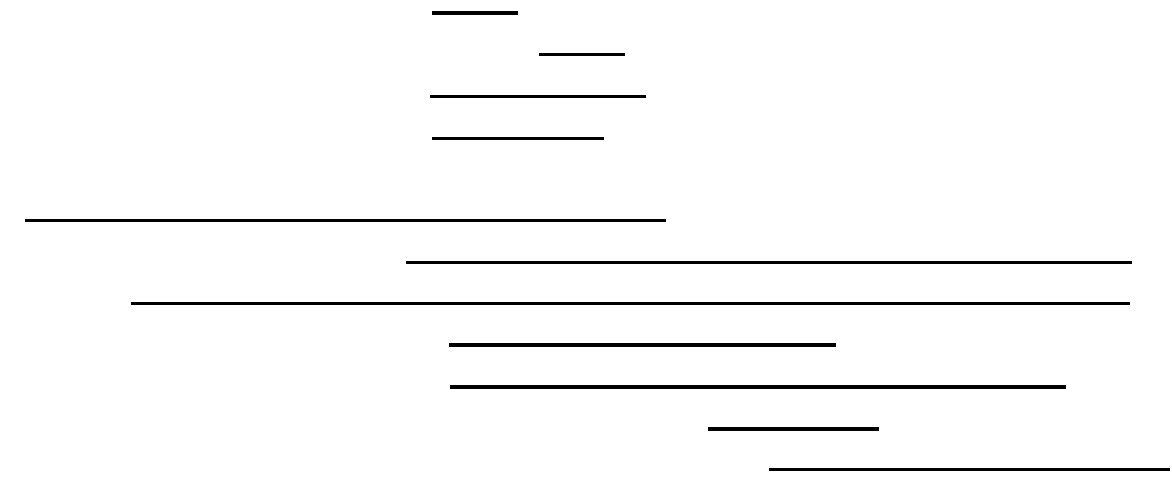


1. Examine the passage of adult salmonids at Three Mile Falls Dam

Prepared By:

Paul D. Kissner

\author{
Confederated Tribes of the Umatilla Indian Reservation \\ Office of Fisheries \\ Department of Natural Resources \\ P.O. Box 638 \\ Pendleton, Oregon 97801
}




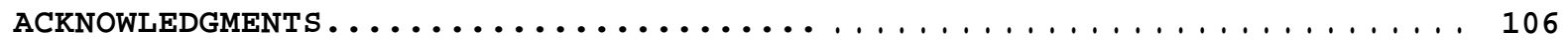

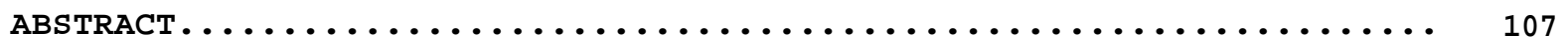

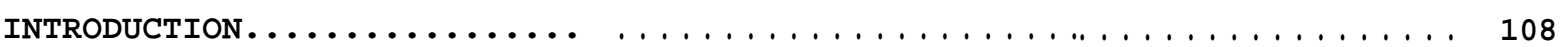

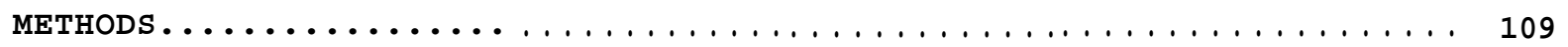

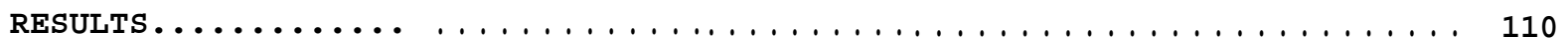

Salmonid Enumeration ........................... 110

Video Data and Visual Observations ................... 116

Spawning Ground Surveys ......................... 118

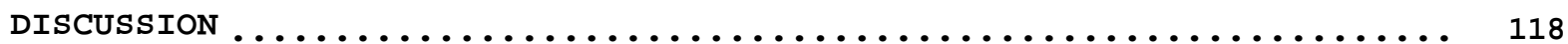

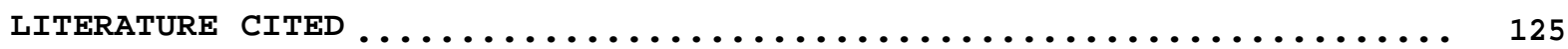

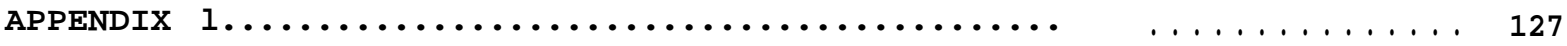

APPENDIX $2 \ldots \ldots \ldots \ldots \ldots \ldots \ldots \ldots \ldots$

APPENDIX $3 \ldots \ldots \ldots \ldots \ldots \ldots \ldots \ldots$ 


\section{ACKNOWLEDGEMENTS}

Keith Kutchins, former passage project leader, developed the study design and conducted all phases of the project.

Special thanks to the following Confederated Tribes of the Umatilla Indian Reservation employees for their assistance: Douglas Olson, Larry Cowapoo, Melvin Farrow and Carl Sampson for collection of fied data and reviewing video tapes, Gerry Rowan for tabulating data, Joe Richards for Administrative Assistance, Gary James for contract management, assistance, and critical review and Celeste Reves and Julie A. Burke for assistance in report preparation. 
The confederated Tribes of the Umatilla Indian Reservation (CTUIR) monitored . river conditions (flow, water temperature, and turbidity) at Three Mile Falls Dam on the Umatilla River, from October, 1990 through June 1991; sampled adult and jack salmon from the east bank holding pond; installed, operated and reviewed video tapes from video recording equipment located at the east bank ladder viewing window and visually observed adult salmon movement through the ladder.

A total of 333 adult, 107 jack and 621 subjack fall chinook salmon, Oncorhvnchus tshawvtscha, 410 adult and 512 jack coho salmon, Oncorhvnchus kisutch, 1,291 adult and 39 jack spring chinook salmon, and 1,110 steelhead, Oncorhvnchus mykiss, were enumerated at Three Mile Falls Dam on the Umatilla River during the period October 1, 1990 through June 30, 1991. Variation in comparison of numbers of adult fall chinook and coho salmon enumerated with video equipment vs. counted through the holding pond exceeded 100\%. Advanced maturation made species identification based on video tape difficult and/or impossible. The amount of movement back and forth in front of the video camera indicated that fish were having difficulty finding the entrance to the holding pond. This is not a serious problem unless fish are being injured during their search. Blocking of a one to two foot section of the lead gate (fish barrier grate) nearest the steep pass, which would separate the flows from the steep pass and lead gate, should permit salmonids to enter the steep pass more rapidly. The problem will not occur when Three Mile Falls Dam is operated in the by-pass mode.

Migration of fall chinook and coho salmon did not correlate with increasing flows, probably because flow levels remained low (150-250 CFS) throughout the period of migration. Increasing numbers of spring chinook salmon adults were enumerated after high flow events as the river flow dropped. 
INTRODUCTION

BACKGROUND

Lack of water for upstream migration of adult salmonids in the Umatilla River has been documented as far back as 1902. The East Oregonian newspaper quoted "Present conditions of the Umatilla River (at Umatilla) are unprecedented. Scarcely any water is visible at this point. Private irrigation enterprise are blamed." Another report by F. B. Holbrock reports "fish hogs are killing off salmon running in the Lower Umatilla River by the thousands. The water is so low the fish are handicapped in moving upstream." The construction of Three Mile Falls Dam by the Bureau of Reclamation (BOR) in 1914 to divert water for irrigation appeared to be another major factor in the extinction of Umatilla River spring and fall chinook and coho salmon. Although a fish ladder was constructed, serious operational problems such as false attraction flows, channel obstruction and sedimentation of the ladder caused a barrier to salmonid migration at most water levels. Only indigenous steelhead have survived, probably because they were able to wait long periods of time until optimal water conditions permitted upstream migration to spawn. Construction of mainstem Columbia River hydroelectric dams, over fishing and degradation of spawning and rearing habitat have exacerbated the decline of salmonids migrating to and from the Umatilla River,

An aggressive program to reestablish spring and fall chinook salmon and coho salmon and supplement the steelhead population began approximately 10 years ago.

Modification to the Umatilla riverbed below Three Mile Fall8 Dam were made in 1984 and 1985 to aid passage at low water. The adult fish ladder at Three Mile Falls Dam was improved in 1987 and 1988 and included modified entrances, increased attraction flows, a ladder designed to prevent stranding and delays in the ladder steps and modified exit structures. Fish ladders have also been constructed at Westland and Cold Springs irrigation diversions.

The study reported here was designed to evaluate the passage of adult salmonids at Three Mile Dam Falls to ensure that adult passage facilities are operated as designed and any mortality that results from injury or delay due to the facility is documented and corrective actions recommended.

The major objective of the Adult Passage Evaluation Project was to examine the passage of adult salmonids through Three Mile Falls Dam at various water flows and to examine adult salmonid passage with the lead gate open and the denil steep pass turned off (camera enumeration'when salmonid are bypassed and not trapped and hauled).

A secondary objective was to determine passage of adult salmonids in the area up to 500 feet below Three Mile Falls Dam and the Maxwell, Westland, and Cold Springs irrigation diversions. 
The Umatilla River in northeast Oregon drains an area of approximately 2290 square miles and discharges its flow into the mainetem Columbia River below McNary Dam. Average flow, based on monthly average flows from 1935-1978 at Umatilla are 428 CFS and range from 23 CFS during July to 1, 096 CHF during April (CTUIR and ODFW 1990).

Major tributaries of the Umatilla River are Meacham, McKay, Birch, and Butter Creeks. Two storage reservoirs, MCKay (73,800 AF) and Cold Springs $(50,000 \mathrm{AF})$ were constructed primarily for irrigation, but also have value in flood control, fish, wildlife and recreation. Five irrigation diversion dams, Stanfield, Westland, Dillon, Maxwell and Three Mile Falls Dam were constructed to channel water to various irrigation districts.

Three Mile Falls Dam, constructed by the United States Bureau of Reclamation (USBR), in 1914 has a crest height of 24 feet and crest length of 915 feet. Construction of new fish passage facilities were completed in 1988 and included reconstruction of the east and west bank fish ladders to improve upstream migration of adult salmonids and construction of adult trapping and viewing facilities.

\section{METHODS}

Flow, turbidity and water temperature were monitored from October 1 , 1990 though June 30, 1991 at Three Mile Falls Dam on the Umatilla River. Water temperature was recorded in degrees centigrade at the right bank facility at hourly intervals with a digital recording Ryan Tempmentor. Turbidity was determined with a secchi disk to the nearest one-tenth of a meter. Discharge date (preliminary) was obtained from the United States Geological Survey, who monitored and record flows (in cubic feet per second) at the Umatilla gage, approximately $1.5 \mathrm{~km}$ below the dam.

All salmonids passing upstream through the right bank (east) fish ladder at Three Mile Falls Dam were captured, enumerated, examined for marks, a portion sampled for age, sex and fork length and the remainder hauled upstream to be released in river or held for broodstock in conjunction with the Umatilla River trap and haul and artificial production projects.

Fall chinook salmon were categorized at Three Mile Falls Dam as adult if greater than 24" fork length, jack if between 18" and 24 " fork length or subjack if less than 18" fork length. Coho salmon were classified as adult if 20 " fork length or larger and jack if less than 20" fork length. Spring chinook salmon were classified as age 5 if 31 " fork length or greater, age 4 if $24 "$ to 30 7/8" fork length and age 3 if less than 24 "fork length for sampling purposes, based on length vs. age data on spring chinook salmon collected at Bonneville Dam (Schwartzberg and Fryer, 1990).

Video equipment and techniques used to record salmonid migration at Three Mile Falls Dam were similar to those described by Kutchine (1990).

Carcass and prespawning mortality surveys were conducted below Three 
Mile Falls Dam, from Westland to Maxwell diversions and above McKay Creek (partly conducted as a tribal and state general fisheries management activity).

\section{RESULTS}

\section{Salmonid Enumeration}

A total of 333 adult, 107 jack and 621 subjack fall chinook salmon, 410 adult and 512 jack coho salmon, 1,110 steelhead and 1,291 adult and 39 jack spring chinook salmon were enumerated at Three Mile Falls Dam trapping facility between October 1, 1990 and June 30, 1991 (Appendix 1). The adult fall chinook salmon returned from October 10 through December 6, 1990 with 89.5\% of the migration being enumerated from October 29 through November 13 . The adult coho salmon returned from October 15 through February 15 with $86.6 \%$ of the migration being enumerated between October 29 through November 13 . Timing of adult fall chinook and coho salmon returning to Three Mile Falls Dam was similar in 1989 (Tables 1 \& 2). The steelhead adult spawning migration through Three Mile Falls Dam occurred from October 19, 1990 through June 11, 1991 with $75.2 \%$ of the escapement being enumerated between February 1,1990 and April 15, 1991. The timing of the 1989-1990 steelhead return to Three Mile Falls Dam was earlier as $74.8 \%$ of the return occurred from January 10 through March 31 (Table 3). The return of spring chinook salmon occurred from April 11 through June 24 and 82.5\% of the fish returned from April 25 through May 29, 1991. Return timing was similar in 1990 (Table 4).

\section{River Conditions}

During 1990, as observed by Kutchins in 1989, there is not a correlation between stream flow and fall salmonid migration (Figure 1). The majority of the fall chinook and coho salmon migrated to Three Mile Falls Dam when flows were between 150-250 CFS and flows did not exceed 255 CFS during this period.

It appears that even at low flows salmonids would have little problem migrating up the Umatilla River to Three Mile Falls Dam. A much more serious consequence of low flow is that little attraction water is available for homing in the Umatilla River from the mainstem Columbia River. For example, average flows at the Umatilla gage are often less than 100 CFS in early October compared to 100,000+ CFS on the mainstem Columbia River near Umatilla. It has been documented that adult fall

chinook salmon have strayed from Umatilla juvenile releases (Rowan, 1991), even after short term acclimation at Bonifer or Minthorn. It appears that the low flows observed in the Umatilla River during October to mid-November (25250 CFS) are probably the major factor in the straying observed for fall chinook salmon.

Peak movement of spring chinook salmon generally occurred as water levels declined after high flow events (Figure 2). A range in flow levels of 500-1,000 CFS during the spring chinook migration appears adequate to permit fish to home with a high degree of reliability. Little straying of adult spring chinook salmon has been documented (Rowan, 1991) from juveniles released in the Umatilla River. 


\begin{tabular}{|c|c|c|c|c|c|c|c|c|}
\hline \multicolumn{9}{|c|}{$\begin{array}{l}\text { Return of adult fall-\&i\&ok. salmon to Three Mile Falls Dam' by week, } \\
1989 \text { and } 1990\end{array}$} \\
\hline \multicolumn{5}{|c|}{1990} & \multicolumn{4}{|c|}{1989} \\
\hline DATE & $\mathbf{N}$ & $\%$ & Accum \% & $\begin{array}{c}x \\
\text { CFS }\end{array}$ & $\mathbf{N}$ & $\%$ & Accum \% & $\begin{array}{l}\mathrm{X} \\
\mathrm{CFS}\end{array}$ \\
\hline Oct. & 1 & .3 & .3 & 68.6 & 28 & 10.0 & 10.0 & 196 \\
\hline $15-21$ & 5 & 1.5 & 1.8 & 118.9 & 12 & 4.3 & 14.3 & 236 \\
\hline $22-28$ & 1 & .3 & 2.1 & 139.6 & 88 & 31.5 & 45.8 & 221 \\
\hline 29-04 & 170 & 51.1 & 53.2 & 150.7 & 30 & 10.8 & 56.6 & 161 \\
\hline Nov & 53 & 15.9 & 69.1 & 232.0 & 47 & 16.8 & 73.4 & 153 \\
\hline $12-18$ & 81 & 24.3 & 93.4 & 220. & 65 & 23.3 & 96.7 & 188 \\
\hline $19-25$ & 6 & 1.8 & 95.2 & 113.4 & 8 & 2.9 & 99.6 & 141 \\
\hline 26-02 & 16 & 4.8 & 100 & 226.3 & 1 & .4 & 100 & 102 \\
\hline
\end{tabular}




\begin{tabular}{|c|c|c|c|c|c|c|c|c|}
\hline Table -2.. & \multicolumn{8}{|c|}{$\begin{array}{l}\text { Raturn } \\
\text { 1989-1990. }\end{array}$} \\
\hline \multicolumn{5}{|c|}{1990} & \multicolumn{4}{|c|}{1989} \\
\hline Date & $\mathbf{N}$ & $\%$ & Accum \% & $\begin{array}{c}x \\
\text { CFS }\end{array}$ & $\mathbf{N}$ & $\%$ & Accum \% & $\begin{array}{c}X \\
\text { CFS }\end{array}$ \\
\hline $0 c t 814$ & 0 & 0 & 0 & 68.6 & 168 & 4.1 & 4.1 & 196 \\
\hline $15-21$ & 8 & 2.0 & 2.0 & 118.9 & 56 & 1.4 & 5.5 & 236 \\
\hline $22-28$ & 6 & 1.5 & 3.5 & 139.6 & 1171 & 28.5 & 34.0 & 221 \\
\hline $29-4$ & 212 & 51.7 & 55.2 & 150.7 & 161 & 3.9 & 37.9 & 161 \\
\hline Nov $5-11$ & 48 & 11.7 & 66.9 & 232.0 & 651 & 15.9 & 53.8 & 153 \\
\hline $12-18$ & 110 & 26.8 & 93.7 & 220.0 & 1503 & 36.6 & 90.4 & 188 \\
\hline $19-25$ & 4 & 1.0 & 94.7 & 113.4 & 116 & 2.8 & 93.2 & 141 \\
\hline $26-2$ & 18 & 4.4 & 99.1 & 226.3 & 60 & 1.5 & 94.7 & 102 \\
\hline 0003.9 & 3 & .7 & 99.8 & 206.3 & 124 & 3.0 & 97.7 & 107 \\
\hline$<10$ & 1 & .2 & 100.0 & & 92 & 2.2 & 99.9 & \\
\hline $70+81$ & 410 & & & & 4102 & & & \\
\hline
\end{tabular}




\begin{tabular}{|c|c|c|c|c|c|c|c|c|}
\hline Table 3 & \multicolumn{8}{|c|}{ Return of Steelhead to Three Mile Falls Dam by two week period 1989-i 991.} \\
\hline \multicolumn{5}{|c|}{ 1990-1991 } & \multicolumn{4}{|c|}{ 1989-1990 } \\
\hline Date & N & $\%$ & $\begin{array}{c}\text { Accum } \\
\%\end{array}$ & $\begin{array}{c}X \\
\text { CFS }\end{array}$ & $\mathbf{N}$ & $\%$ & $\begin{array}{c}\text { Accum } \\
\%\end{array}$ & $\begin{array}{c}X \\
\text { CFS }\end{array}$ \\
\hline Oct $1-15$ & 2 & .2 & .2 & 59.1 & 30 & 1.8 & 1.8 & 156 \\
\hline $16-31$ & 13 & 1.2 & 1.4 & 133.8 & 88 & 5.3 & 7.1 & 217 \\
\hline Nov 15 & 28 & 2.5 & 3.9 & 211.7 & 40 & 2.4 & 9.5 & 162 \\
\hline $16-30$ & 19 & 1.7 & 5.6 & 177.1 & 20 & 1.2 & 10.7 & 139 \\
\hline Der $1 / 15$ & 37 & 3.3 & 8.9 & 178.6 & 9 & .5 & 11.2 & 106 \\
\hline $16-31$ & 9 & .8 & 9.7 & $\begin{array}{c}\text { gage } \\
\text { broken }\end{array}$ & 2 & .1 & 11.3 & 98 \\
\hline Jan $1-15$ & _o_ & 0 & 9.7 & 508.1 & 132 & 7.9 & 19.2 & 331 \\
\hline $16-31$ & 59 & 5.3 & 15.0 & 853.1 & 352 & 21.1 & 40.3 & 193 \\
\hline & 268 & 24.1 & 39.1 & 488.9 & 36 & 2.2 & 42.5 & 374 \\
\hline $16-28$ & 173 & 15.6 & 54.7 & 1261.5 & 185 & 11.1 & 53.6 & 598 \\
\hline Mar $1-15$ & 104 & 9.4 & 64.1 & 788.3 & 217 & 13.0 & 66.6 & 835 \\
\hline $16-31$ & 89 & 8.0 & 72.1 & 610 & 326 & 19.5 & 86.1 & 755 \\
\hline Apr 1 -15 & 202 & 18.2 & 90.3 & 862 & 114 & 6.8 & 92.9 & 280 \\
\hline $16-30$ & 76 & 6.8 & 97.1 & 713 & 75 & 4.5 & 97.4 & 333 \\
\hline $\mathrm{Mav}$ & 26 & 2.3 & 99.4 & 638 & 42 & 2.5 & 99.9 & 1064 \\
\hline $16-31$ & 7 & .6 & 100.0 & 3214 & 0 & 0 & 99.9 & \\
\hline $5,10 \% \div 1$ & $111_{2}$ & & & & 1668 & & & \\
\hline
\end{tabular}




\begin{tabular}{|c|c|c|c|c|c|c|c|c|}
\hline \multirow{2}{*}{\multicolumn{5}{|c|}{ Table 4}} & \multicolumn{4}{|c|}{ Three Mile Falls Dam by week, } \\
\hline & & & & & \multicolumn{4}{|c|}{1990} \\
\hline DATE & $\mathbf{N}$ & $\%$ & Accum \% & $\begin{array}{c}x \\
\text { CFS }\end{array}$ & $\mathbf{N}$ & $\%$ & Accum \% & $\begin{array}{c}x \\
\text { CFS }\end{array}$ \\
\hline $\begin{array}{l}\text { April } \\
11-17\end{array}$ & 19 & 1.5 & 1.5 & 1068 & 4 & .2 & .2 & 77 \\
\hline $18-24$ & 44 & 3.4 & 4.9 & 695 & 2 & .1 & .3 & 38 \\
\hline 25-01 & 219 & 17.0 & 21.9 & 689 & 182 & 8.4 & 8.7 & 961 \\
\hline $\begin{array}{l}\text { May } \\
02-08\end{array}$ & 147 & 11.4 & 33.3 & 589 & 888 & 41.1 & 49.8 & $6^{137}$ \\
\hline $09-15$ & 391 & 30.3 & 63.6 & 658 & 499 & 23.1 & 72.9 & 246 \\
\hline $16-22$ & 107 & 8.2 & 71.8 & 5308 & 53 & 2.5 & 75.4 & 53 \\
\hline $23-29$ & 201 & 15.6 & 87.4 & 1868 & 130 & 6.0 & 81.4 & 48 \\
\hline $30-05$ & 81 & 6.3 & 93.7 & 513 & 311 & 14.4 & 95.8 & 981 \\
\hline$\frac{5,0}{06-12}$ & 56 & 4.3 & 98.0 & & 69 & 3.2 & 99.0 & 545 \\
\hline $13-19$ & 24 & 1.9 & 99.9 & & 18 & .8 & 99.8 & 145 \\
\hline $20-26$ & 2 & .2 & 100.1 & & 2 & .1 & 99.9 & 12 \\
\hline
\end{tabular}




$$
\text { Hothl }
$$


Average daily water temperatures ranged from . 5 c in December to 20.0 c during June (Appendix 2). Turbidity ranged from the clearest water in early May (2.OM) to the most turbid several weeks later during a major flood (.2M).

Video Data and Visual Observations

The fall chinook and coho salmon spawning migration was video taped at Three Mile Falls Dam during October through November, 1990. As observed during the spring chinook and steelhead salmon spawning migration during February through May of 1990 (Kutchins, 1990), the fall chinook and coho salmon moved upstream past the video recording window then back downstream of the window many times before finally moving upstream through the denil steep pass to the holding pond (Appendix 3). When the denil steep pass and holding pond are operated there is much more attraction water coming through the lead gate then the steep pass and fish are obviously having difficulty being attracted to the steep pass. This delay in entrance to the holding pond is probably not serious unless fish are physically injuring themselves during their search to migrate into the facility. During the 1991 spring chinook adult spawning migration a number of recent injuries were noted; however, it was unclear where these injuries were occurring. Blocking of a one or two foot section of the lead gate nearest the steep pass, which would separate the flows from the steep pass and lead gate should permit salmonids to enter the steep pass more rapidly.

Enumeration of the escapement of fall chinook and coho salmon at Three Mile Falls Dam by video camera during 1990 was extremely difficult because of these back and forth movements and advanced maturation of the fall chinook and coho salmon which made species identification difficult and/or impossible.

For example, during the period october 31 (2pm) through November 14, a total of 269 adult Coho, 232 adult fall chinook, 28 steelhead, 261 jack coho, 49 jack fall chinook and 335 subjack fall chinook were enumerated at the holding facility at Three Mile Falls Dam. Analysis of video tapes during this period indicated that 132 adult coho, 673 adult fall chinook, 64 steelhead and 883 unidentified fish were enumerated (Table 5). Variation in comparison of adult salmonid numbers by the two methods exceeded $100 \%$.

Based on video counts from six twenty-four hour periods in October and November hourly movement of fall chinook salmon varied greatly from day to day (Table 6).

The west bank adult ladder and trap was operated for a three day evaluation period and several operational difficulties were noted. The ladder has exposed metal corner edging and keyways which could cause injuriee to returning adults. The spacing in the v-trap fingers may allow jacks and steelhead to escape upstream. The v-trap has to be closed each time the fish are to be crowded. The crowder does not have enough vertical lift to force fish into the lift system. The crowder foot and lift system entrance are too narrow. The lift system is completely enclosed which does not allow the fish being loaded to be observed anytime between exiting the pond and entering the truck. There are also no provisions for sorting or enumerating any fish that have been captured.

In addition, the flood of May 18-24 silted in the intake channels for 


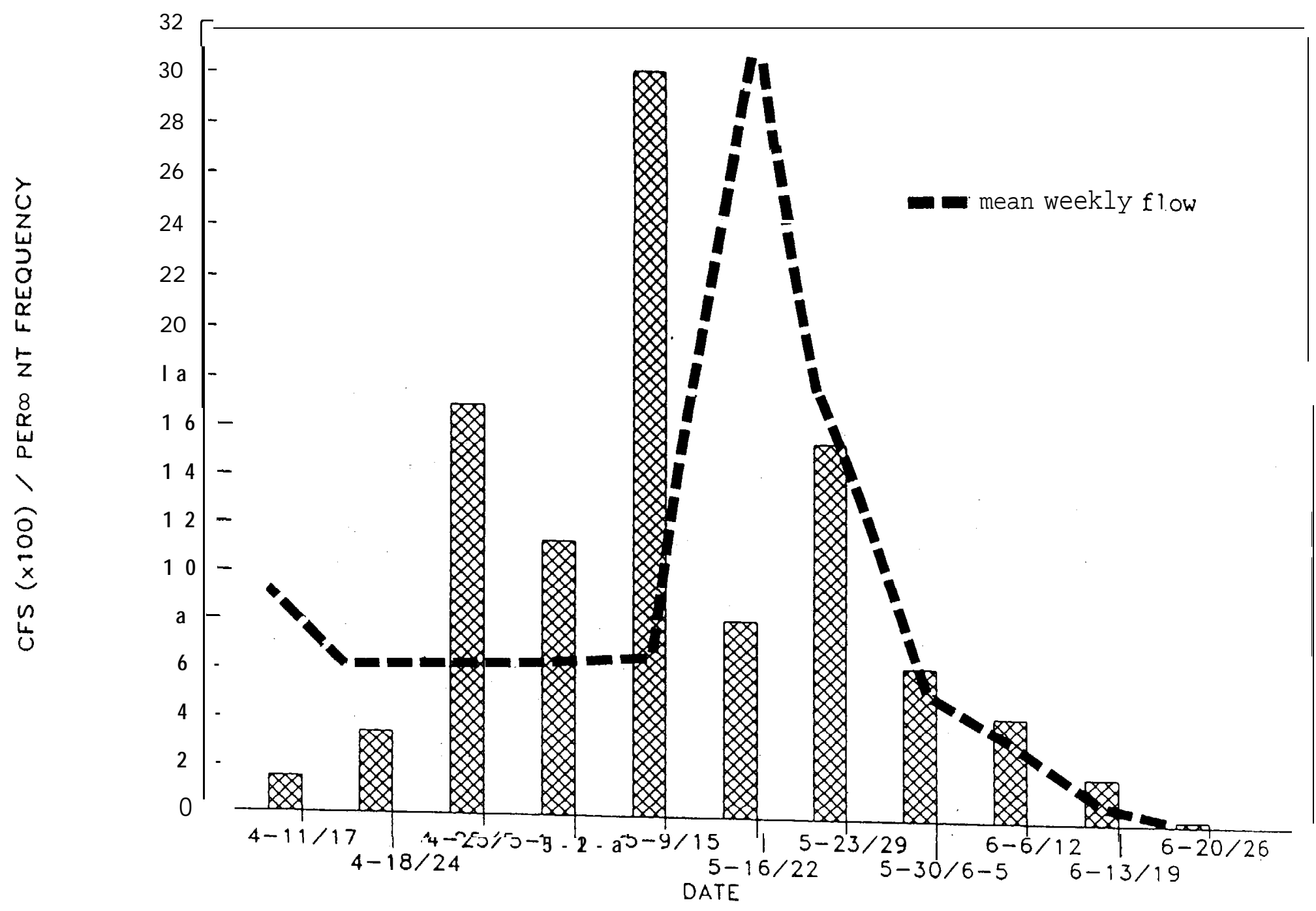

Figure 2. Percent frequency of adult spring chinook salmon returning by week to Threemile Falls Dam on the Umatilla River compared to mean weekly flow, $1991(\mathrm{~N}=1,291)$. 
both the ladder, trap and attraction water. substantial dredging will be necessary to re-open the adult portion at the facility. In our opinion, the west bank facility should be operated in a swim through mode only after modifications are made to prevent possible injuries while passing the facility.

Two of the objectives, examination of the adult passage with the lead gate open and denil steep pase turned off and examination of passage at Maxwell, Westland and Cold Springs irrigation diversions were not accomplished because Three Mile Fall Dam was not operated in the fish by-pass mode, and flows remained below trap and haul criteria throughout the year (0lson, 1990$)$.

Soawnina Ground Survevs

Four spawning ground surveys were conducted below Three Mile Falls Dam during November and December of 1990 to evaluate possible prespawning mortality and/or passage problems of fall chinook and coho salmon and to enumerate the escapement (Table 7).

Comparison of the enumerated escapement of adult fall chinook salmon through Three Mile Falls Dam with the number of fish observed during escapement surveys below Three Mile Falls Dam indicates that a minimum of $24.8 \%$ of the fall chinook return spawned below the dam. This appears to be a high percentage of the escapement to spawn in a marginal area (ie. mostly bedrock with a little available gravel) and indicates possible passage problems. However, the majority of the adult coded wire tag recoveries from the 1990 fall chinook escapement were from juvenile releases that occurred below Three Mile Falls Dam in 1986, and a v-notch was removed from the fish ladder on November 17, 1990 after it was discovered that very large fish were unable to pass through the opening. The v-notch has since been modified and now has an adjustment opening range of 3.0 to 8.0 inches.

Prespawning surveys of spring chinook salmon were conducted in late June through mid-July to determine if significant prespawning mortality was occurring in the Umatilla River. A total of 194 spring chinook salmon were observed in the Umatilla River and tributaries and an additional 73 were observed in the Tribal harvest. Four fish were observed with minor fungus, two were fungused severely (prespawning mortality eminent) and four mortalities were noted (Table 8 ).

Additional prespawning mortality surveys will be conducted in early to mid-August, 1991 .

\section{DISCUSSION}

The objective of the video camera technology developed at Three Mile Falls Dam (Kutchine, 1990) wae to aid in current evaluation of the passage of adult salmonids and to evaluate if video camera technology could be utilized to accurately enumerate the various adult salmonid returns in the future, when the facility is operated in the by-pass mode.

The video camera study has shown that salmonids are having difficulty 
Table 5. Preliminary video counts versus trap counts for Threemile Falls Dam, east bank $1990 / 1991$.

\section{Video Tape counts}

\begin{tabular}{|c|c|c|c|c|c|c|c|c|c|c|c|c|c|c|c|}
\hline Date & Tape & Coho & Chf & sth & Unk & Total & $\begin{array}{l}\text { Coho } \\
\text { Adult }\end{array}$ & $\begin{array}{l}\text { Coho } \\
\text { Jack }\end{array}$ & $\begin{array}{c}\text { Che } \\
\text { Adult }\end{array}$ & $\begin{array}{l}\text { Che } \\
\text { Jack }\end{array}$ & $\begin{array}{l}\text { Che } \\
\text { SubJack }\end{array}$ & $\begin{array}{c}\text { Sth } \\
\text { Total }\end{array}$ & $\begin{array}{l}\text { Total } \\
\text { Adult }\end{array}$ & $\begin{array}{l}\text { Total } \\
\text { SJ/Jk }\end{array}$ & Total \\
\hline $10 / 01 / 90$ & 1 & 1 & 0 & 0 & 0 & 1 & & & $--\infty-\infty-\infty$ & & & & & $--\infty-\cdots-$ & - \\
\hline $10 / 02 / 90$ & 1,2 & 22 & 0 & 0 & 2 & 24 & & & & & & & & & \\
\hline $10 / 03 / 90$ & 2 & 4 & 0 & 0 & 18 & 22 & & & & & & & & & \\
\hline $10 / 04 / 90$ & 2 & 0 & 2 & 0 & 3 & 5 & & & & & & & & & \\
\hline $10 / 05 / 90$ & 2,3 & 1 & 0 & 0 & 5 & 6 & 0 & 2 & 0 & 2 & 2 & 0 & 0 & 6 & 6 \\
\hline $10 / 06 / 90$ & 3 & 1 & 0 & 0 & 2 & 3 & & & & & & & & & \\
\hline $10 / 07 / 90$ & 3 & 0 & 0 & 0 & 2 & 2 & & & & & & & & & \\
\hline $10 / 08 / 90$ & 3,4 & 0 & 0 & 0 & 4 & 4 & & & & & & & & & \\
\hline $10 / 09 / 90$ & 4 & 0 & 0 & 1 & 0 & 1 & & & & & & & & & \\
\hline $10 / 10 / 90$ & 4 & 1 & 0 & 0 & 3 & 4 & 0 & 2 & 1 & 0 & 7 & 1 & 2 & 9 & 11 \\
\hline $10 / 11 / 90$ & 4,5 & 0 & 0 & 1 & 0 & 1 & & & & & & & & & \\
\hline $10 / 12 / 90$ & 5 & 0 & 0 & 0 & 11 & 11 & & & & & & & & & \\
\hline $10 / 13 / 90$ & 5 & 0 & 1 & 0 & 8 & 9 & & & & & & & & & \\
\hline $10 / 14 / 90$ & 5,6 & 0 & 0 & 0 & 5 & 5 & & & & & & & & & \\
\hline $10 / 15 / 90$ & 6 & 2 & 2 & 0 & 25 & 29 & 1 & 21 & 0 & 4 & 15 & 2 & 2 & 40 & 42 \\
\hline $10 / 16 / 90$ & 6 & 3 & 5 & 2 & 41 & 51 & & & & & & & & & \\
\hline $10 / 17 / 90$ & 6,7 & 3 & 1 & 0 & 46 & 50 & & & & & & & & & \\
\hline $10 / 18 / 90$ & 7 & 0 & 0 & 1 & 39 & 40 & 7 & 65 & 5 & 6 & 34 & 5 & 17 & i05 & 122 \\
\hline $10 / 19 / 90$ & 7,8 & 0 & 0 & 0 & 45 & 45 & & & & & & & & & \\
\hline $10 / 20 / 90$ & 8 & 0 & 0 & 0 & 47 & 47 & & & & & & & & & \\
\hline $10 / 21 / 90$ & 8 & 0 & 0 & 1 & 34 & 35 & & & & & & & & & \\
\hline $10 / 22 / 90$ & 8,9 & 5 & 2 & 1 & 17 & 25 & 1 & 36 & 0 & 1 & 15 & 1 & 2 & 52 & 54 \\
\hline $10 / 23 / 90$ & 9 & 0 & 9 & 0 & 5 & 1 & 4 & & & & & & & & \\
\hline $10 / 24 / 90$ & 9 & 8 & 4 & 0 & 2 & 14 & & & & & & & & & \\
\hline $10 / 25 / 90$ & 9,10 & 3 & 0 & 0 & 7 & 10 & 5 & 12 & 1 & 4 & 24 & 2 & 8 & 40 & 48 \\
\hline $10 / 26 / 90$ & 10 & 1 & 0 & 1 & 2 & 4 & & & & & & & & & \\
\hline $10 / 27 / 90$ & 11 & 3 & 11 & 0 & 9 & 23 & & & & & & & & & \\
\hline $10 / 28 / 90$ & 11 & 3 & 17 & 0 & 41 & 61 & & & & & & & & & \\
\hline $10 / 29 / 90$ & 21 & 14 & 21 & 4 & 140 & 179 & 10 & 14 & 19 & 13 & 60 & 2 & 31 & 87 & 118 \\
\hline $10 / 30 / 90$ & 11,12 & 18 & 124 & 5 & 142 & 209 & & & & & & & & & \\
\hline $10 / 31 / 90$ & 12 & 16 & 100 & 4 & 175 & 295 & 76 & 53 & 47 & 22 & 111 & 3 & 126 & 186 & 312 \\
\hline
\end{tabular}


Table 5. (continued)

Video Tape Counts

Trap Counts

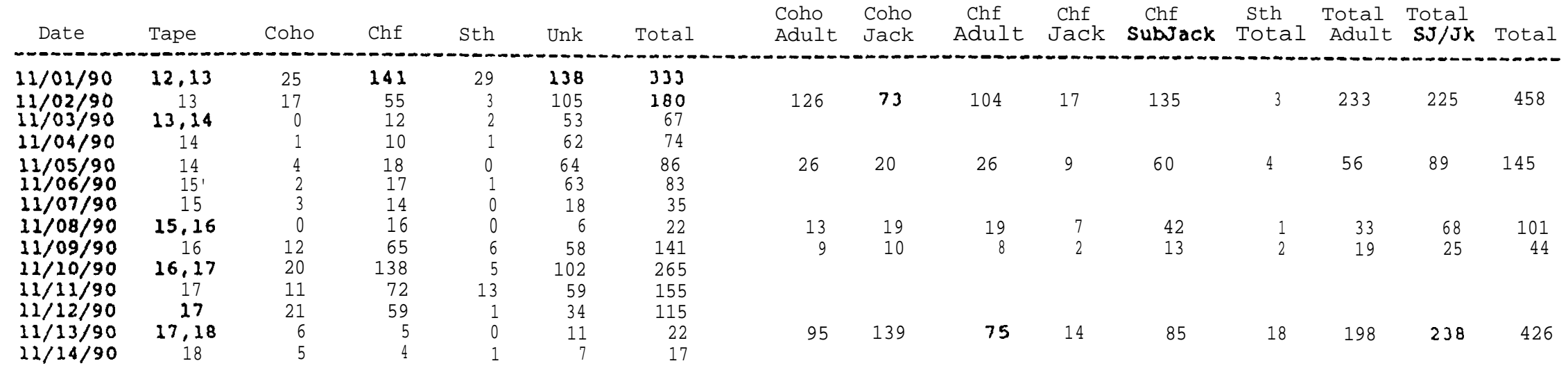




\begin{tabular}{||c|c|c|c|c|c|c||}
\hline \hline Table 6. & \multicolumn{1}{|c||}{$\begin{array}{c}\text { Percent frequency of fall chinook salmon migrating past the viewing window at } \\
\text { Three Mile Falls Dam by four hour periods, } 1990 .\end{array}$} \\
\hline \multicolumn{7}{||c|}{ DATE } \\
\hline TIME & OCT. 30 & OCT. 31 & NOV. 01 & NOV. 09 & NOV. 10 & NOV. 10 \\
\hline 4-4 AM & $5.6 \%$ & $13.0 \%$ & 14.9 & $0 \%$ & 5.1 & 18.1 \\
\hline 8-12 AM & $14.5 \%$ & $12.0 \%$ & 18.4 & 3.0 & 10.9 & 30.6 \\
\hline $12-4$ PM & $21.8 \%$ & $25.0 \%$ & 9.9 & 13.8 & 16.7 & 8.3 \\
\hline 4-8 PM & $28.2 \%$ & $19.0 \%$ & 7.8 & 18.5 & 28.3 & 1.4 \\
\hline 8-12 PM & $15.3 \%$ & $14.0 \%$ & $24.1 \%$ & 63.1 & 15.9 & 2.8 \\
\hline \hline & & $17.0 \%$ & 24.8 & 1.5 & 23.2 & 38.9 \\
\hline N = & 124 & 100 & 141 & 65 & 138 & 72 \\
\hline
\end{tabular}




\begin{tabular}{|c|c|c|c|c|c|c|c|c|c|c|c|}
\hline \multicolumn{2}{|c|}{ Table 7} & \multicolumn{10}{|c|}{$\begin{array}{l}\text { Spawning ground survey from } 700 \text { feet below Three Mile Falls Dam to river mouth } \\
\text { backwater, } 1990 \text {. }\end{array}$} \\
\hline \multicolumn{4}{|c|}{ Redds } & \multicolumn{4}{|c|}{ Live Fish } & \multicolumn{4}{|c|}{ Dead Fish } \\
\hline Date & Miles & Occ. & Unocc. & $\mathrm{CHF}$ & $\mathrm{COH}$ & Unid. & TOT. & $\mathrm{CHF}$ & $\mathrm{COH}$ & Unid. & Total \\
\hline $11 / 09$ & 2.5 & 8 & 8 & 13 & 9 & 11 & 33 & $3^{N}$ & $1^{8 /}$ & 0 & 4 \\
\hline $11 / 28$ & 2.5 & 5 & 11 & 8 & 0 & 0 & 8 & $44^{c \prime}$ & $1^{0 \prime}$ & 1 & 46 \\
\hline $12 / 05$ & 2.5 & 14 & 39 & 15 & 0 & 0 & 15 & $48^{\varepsilon}$ & $2^{F \prime}$ & 4 & 54 \\
\hline $12 / 18$ & 2.5 & 0 & 20 & 1 & 0 & 0 & 1 & $25^{a /}$ & $1^{\mathrm{H}}$ & 3 & 29 \\
\hline TOTAL & 2.5 & 14 & 39 & 37 & 9 & 11 & 57 & 120 & 5 & 8 & 133 \\
\hline \multicolumn{12}{|c|}{ N M:F $=03.0(n=3) ; 3$ spawned out. 0 prespawn morts: 0 jacks; 0 CWT, 0 snouts } \\
\hline \multicolumn{12}{|c|}{ B: $M: F=1: 0(n=1) ; 1$ spawned out, 0 prespawn morts: 1 jack; 0 CWT, 0 snouts } \\
\hline \multicolumn{12}{|c|}{ ct $M: F=1: 1.1(N=38) ; 35$ spawned out, 3 prespawn morts; 6 jacks; $16 \mathrm{CWT}, 15$ snouts } \\
\hline \multicolumn{12}{|c|}{ of $M: F=0: 1$ ( $n=1$ ): 0 spawned out, 1 prespawn mort; 0 jacks; 0 CWT, 0 snouts } \\
\hline \multicolumn{12}{|c|}{ E $M: F=1: 2.6(n=47): 46$ spawned out, 1 prespawn mort : 1 jack : $20 \mathrm{CWT}, 20$ snouts } \\
\hline \multicolumn{12}{|c|}{ Fl 2 jacks } \\
\hline \multicolumn{12}{|c|}{ a $M: F=1: 2.1(n=22) ; 22$ spawned out, 0 prespawn morts; 3 jacks; 6 CWT. 6 snouts } \\
\hline
\end{tabular}


locating the steep pass entrance. This is not a serious problem unless injuries are occurring that cause prespawning mortality and will not occur when the facility is operated in the by-pass mode.

We feel that from the operational experience gained from this project, the return of steelhead and spring chinook salmon can accurately be determined utilizing video technology when Three Mile Falls Dam is operated in the bypass mode. It appears that it will be many years before Three Mile Falls Dam will be operated in a by-pass mode because of evaluation of various enhancement strategies involving CWT sampling of returning adult salmonids and because minimum flow criteria for trap and haul usually are not exceed (Olson, 1990).

The video camera study also helped determine that the v-notch was to small to permit passage of large chinook salmon.

It is obvious that accurate enumeration of salmonids from video tapes of the fall adult salmonid return to the Umatilla River is difficult. Identification of fall chinook and coho salmon, which is the major problem, could possibly be apportioned by sampling at the holding pond. Biological data such as age, sex and size could be collected concurrently.

Suggestions for future operation of a video system when Three Mile Falls Dam is operated in the by-pass mode include: 1) back up system with alternative power supply for power outages; 2) close fish ladder during extremely turbid conditions (less that .2' secchi disk reading); 3 ) read tapes daily to trouble shoot potential problems.

The adult passage project should now concentrate on evaluating the passage of adult salmonids throughout the year, at various flow levels, from the lower Umatilla River, past all irrigation diversions and associated ladders. The Stanfield Dam ladder (to be operational in the Fall of 1992) will be the last of the four major adult passage facilities to be completed in the lower Umatilla River. Because of the relatively small numbers of adults anticipated to be released directly above Three Mile Dam in the near future, visual observations to evaluate passage would be very difficult. Evaluation should include definition of flow levels necessary for successful movement through the various diversions and injuries and/or prespawning morality associated with migration. Radio tagging is recommended, with a feasibility study being conducted during 1991-1992. The pilot radio tagging project should develop capture, handling, tagging, and radio tag monitoring techniques. Additional fish should be captured and marked at various locations at and below Three Mile Falls Dam. Comparison of recovery percentages at Three Mile Falls Dam and observations on injuries should aid in determination of where injuries observed at Three Mile Falls Dam are occurring. A large scale radio tagging and tracking study in 1992 and 1993 should follow the feasibility study in order to evaluate adult salmonid passage throughout the entire lower Umatilla River.

The passage project may then be able to better define criteria for trap and haul by determining flow requirements for passage and timing from Three Mile Falls Dam upstream through the various irrigation diversions.

Additionally the passage projects should collect all available timing 
data associated with Umatilla River fall chinook salmon throughout the Columbia River in an attempt to determine the timing of peak abundance at the Umatilla River mouth. The proper release timing and amount of McKay Reservoir water released for fish migration in the future may be critical to minimize straying of Umatilla River fall chinook salmon. 
Confederated Tribes of the Umatilla Indian Reservation and Oregon Department of Fish and Wildlife (CTUIR and ODFW). 1990.

Columbia Basin System Planning, Umatilla Subbasin, September, 1990. Submitted to Northwest Power Planning Council and Columbia Basin Fish and Wildlife Authority, Portland, Oregon.

Kutchins, K. 1990, Report B:

Examine the passage of adult salmonids at Three Mile Falls Dam. Pages 33-61 in A.A. Nigro, editor. Evaluation of juvenile fish by pass and adult fish passage facilities at Three Mile Falls Dam, Umatilla River. Report to Bonneville Power Administration (Project 89-024-01), Portland, Oregon.

Olson, D.E., 0. James, B. Duke, and J. Phelps, 1990.

Trapping and transportation of adult and juvenile salmon in the lower Umatilla River in northeast Oregon, 1989-1990. Report to Bonneville Power Administration (Project 88-022), Portland, Oregon.

Rowan, G. 1991

Operation, maintenance and evaluation of the Bonifer and Minthorn springs juvenile release and adult collection facilities. Report to Bonneville Power Administration (Project 83-435), Portland, Oregon.

Schwartzberg, M and J. Fryer 1990

Age and length composition of Columbia Basin spring chinook salmon sampled at Bonneville Dam in 1989. Columbia River Inter-Tribal Fish Commission Technical Report 90-1. 


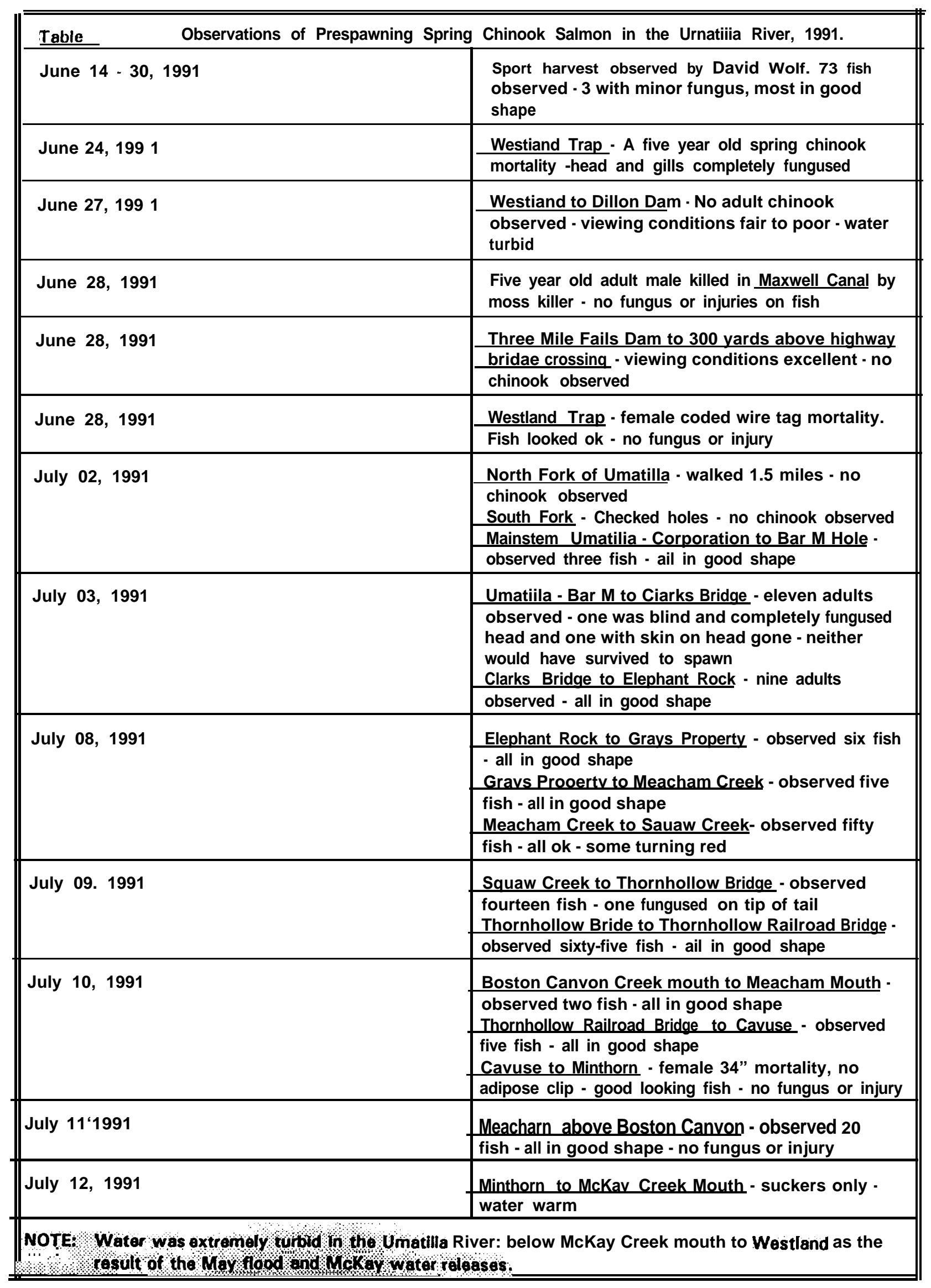


Appendix 1. Spring chi nook returns to Threenile Falls Dam (right bank) on the Umatilla River in 1991.

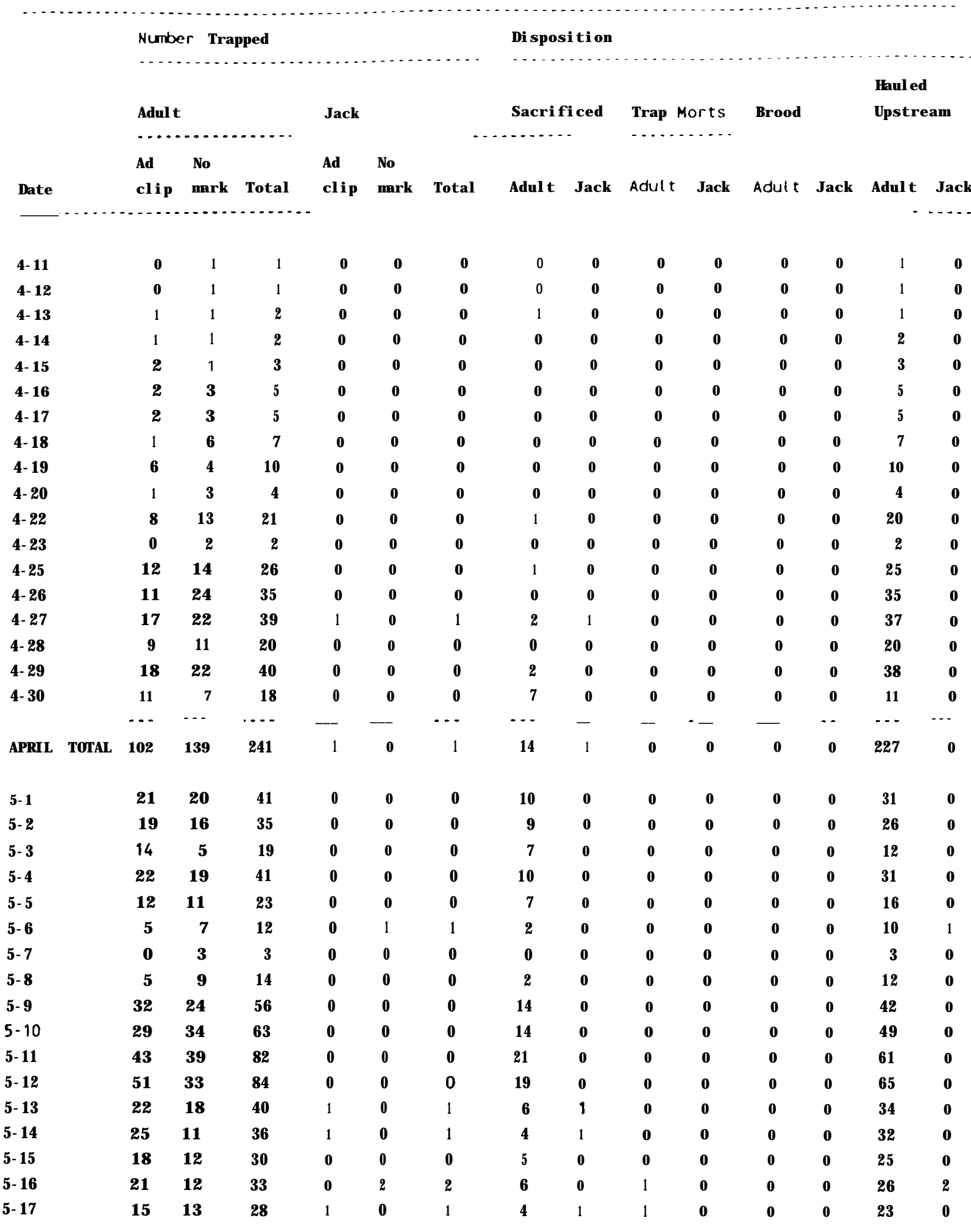


Appendi $x$ 1. (cont.)

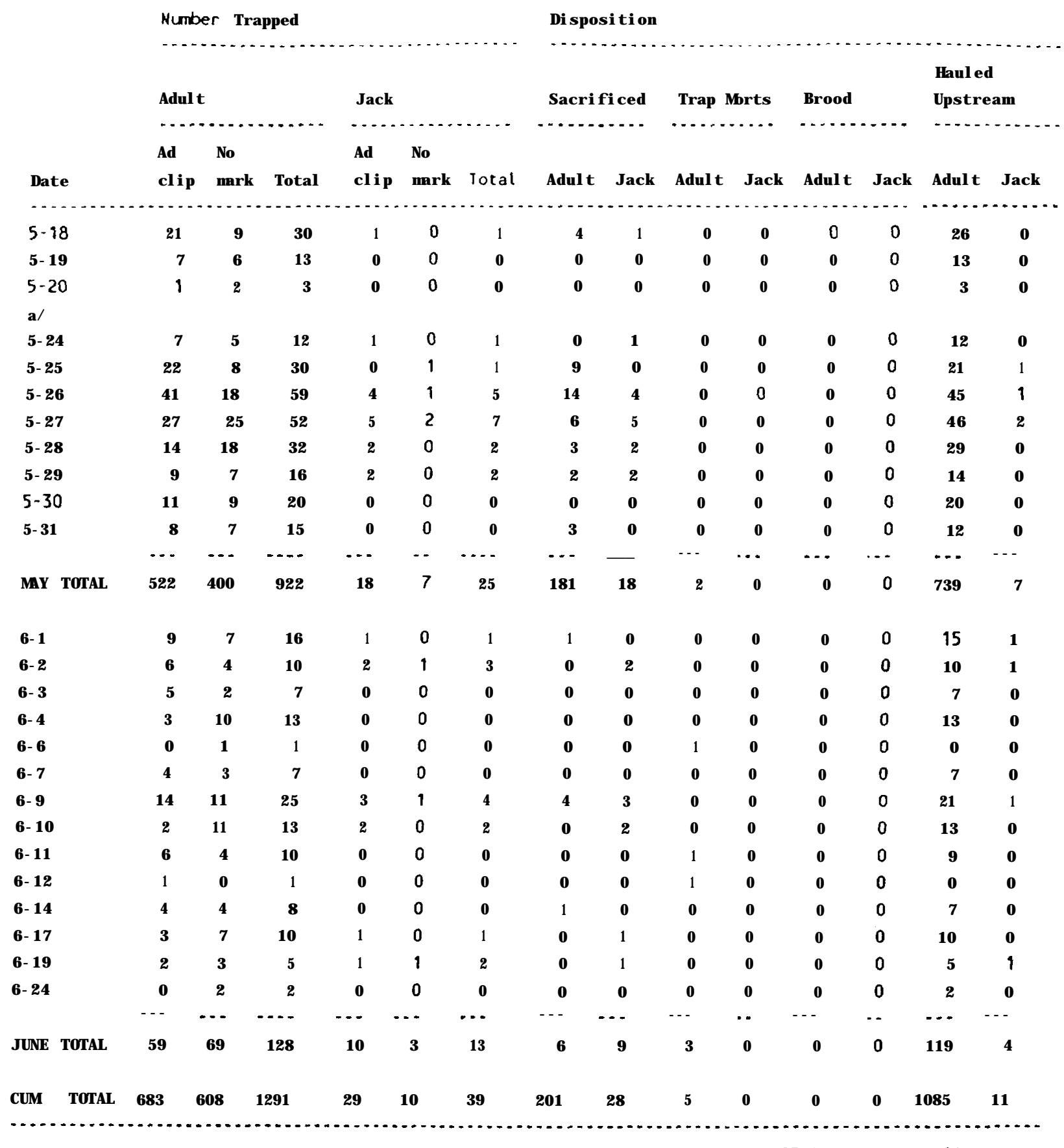

Revi sed: 6-24-91

CTUIR File Nane: D:/123R2/OATA/SUMCHS 91

a/ The trap was shut down from 5-21 to 5-23 due to fl ood conditions. 
Appendi $x$ 1. Summer steel head returns to Threemile falls Dam (right bank) on the Umatilla Ri ver in $1990-1991$.

\begin{tabular}{|c|c|c|c|c|c|c|c|c|c|}
\hline \multirow[b]{4}{*}{ DATE } & \multicolumn{4}{|c|}{ Number Trapped } & \multicolumn{5}{|c|}{ Di sposition } \\
\hline & \multicolumn{9}{|c|}{$\ldots \ldots \ldots \ldots \ldots \ldots \ldots \ldots \ldots$} \\
\hline & \multirow{2}{*}{$\begin{array}{l}\text { LV } \\
\text { cl i p }\end{array}$} & \multirow{2}{*}{$\begin{array}{l}\text { Ad } \\
\text { cl i p }\end{array}$} & \multicolumn{2}{|l|}{$\mathbf{N b}$} & \multirow[b]{2}{*}{ Sacri fi ced } & \multicolumn{2}{|l|}{ Trap } & Rel eased & \multirow{2}{*}{$\begin{array}{c}\text { Haul ed } \\
\text { Upstream }\end{array}$} \\
\hline & & & mark & Total & & Morts & Brood & a Dam & \\
\hline$\cdots+-\infty+\infty$ & $\cdots--$ & $\cdots \cdot$ & $\cdots$ & $\cdots \ldots$ & $\cdots+$ & $\cdots$ & $\ldots \ldots$ & $\ldots \ldots$ & $\ldots \ldots$ \\
\hline $10-05$ & 0 & $\mathbf{0}$ & $\mathbf{0}$ & 0 & 0 & 0 & 0 & 0 & $\mathbf{0}$ \\
\hline 10- 10 & 0 & $\mathbf{0}$ & 1 & 1 & 0 & 0 & 0 & 0 & 1 \\
\hline $10-15$ & 0 & $\mathbf{0}$ & 1 & 1 & $\mathbf{0}$ & $\mathbf{0}$ & $\mathbf{0}$ & $\mathbf{0}$ & 1 \\
\hline $10-18$ & 0 & $\mathbf{0}$ & 5 & 5 & $\mathbf{0}$ & 0 & 0 & 0 & 5 \\
\hline 10- 22 & 0 & $\mathbf{0}$ & 1 & 1 & 0 & $\mathbf{0}$ & 0 & 0 & 1 \\
\hline $10-25$ & 0 & 0 & 2 & 2 & 0 & 0 & 0 & 0 & 2 \\
\hline $10-29$ & 0 & 0 & 2 & 2 & 0 & 0 & 0 & 0 & 2 \\
\hline \multirow[t]{2}{*}{$10-31$} & 1 & 1 & 1 & 3 & 0 & 0 & 1 & 0 & 2 \\
\hline & $\cdots$ & $\cdots$ & $\ldots$ & $\cdots$ & --- & $\cdots$ & $\cdots$ & -- & $\cdots$ \\
\hline OCT TOTAL & 1 & 1 & ' 13 & 15 & 0 & 0 & 1 & 0 & 14 \\
\hline $11-2$ & 0 & 0 & 3 & 3 & 0 & 0 & 3 & 0 & 0 \\
\hline 11- 5 & 0 & 0 & 4 & 4 & 0 & 0 & 2 & 0 & 2 \\
\hline 11- 8 & 0 & 1 & 0 & 1 & 0 & 0 & 0 & 0 & 1 \\
\hline 11- 9 & 0 & 0 & 2 & 2 & 0 & 0 & 1 & 0 & 1 \\
\hline 11- 13 & 2 & 1 & 15 & 18 & 0 & 0 & 6 & 0 & 12 \\
\hline 11- 16 & 0 & 1 & 5 & 6 & 0 & 0 & 0 & 0 & 6 \\
\hline 11- 19 & 0 & 0 & 2 & 2 & 0 & 0 & 0 & 0 & 2 \\
\hline 11- 21 & 0 & 0 & 1 & 1 & 0 & 0 & D & 0 & 1 \\
\hline 11- 26 & 1 & 0 & 5 & 6 & 0 & 0 & 1 & 0 & 5 \\
\hline \multirow[t]{2}{*}{ 11- 30} & 0 & 0 & 4 & 4 & 0 & 0 & 0 & 0 & 4 \\
\hline & $\cdots$ & $\cdots$ & --- & -- & --- & $\cdots$ & $\cdots$ & -- & $\cdots$ \\
\hline NOV TOTAL & 3 & 3 & 41 & 47 & 0 & 0 & 13 & 0 & 34 \\
\hline $12-3$ & 0 & 2 & 9 & 11 & 0 & 0 & 0 & 0 & 11 \\
\hline 12- 6 & 1 & 0 & 6 & 7 & 0 & 0 & 1 & 0 & 6 \\
\hline 12- 10 & 0 & 0 & 9 & 9 & 0 & 0 & 0 & 0 & 9 \\
\hline $12-13$ & 0 & 5 & 5 & 10 & 0 & 0 & 5 & 0 & 5 \\
\hline 12- 17 & 0 & 0 & 3 & 3 & 0 & 0 & 0 & 0 & 3 \\
\hline 12- 26 & 0 & 0 & 0 & 0 & 0 & 0 & 0 & 0 & 0 \\
\hline 12- 27 & 2 & 0 & 4 & 6 & 0 & 0 & 2 & 0 & 4 \\
\hline \multirow[t]{2}{*}{ 12- 31} & 0 & 0 & 0 & 0 & 0 & 0 & 0 & 0 & 0 \\
\hline & $\cdots$ & $\cdots$ & --- & $\ldots$ & -- & $\cdots$ & $\cdots$ & -- & -- \\
\hline OEC TOTAL & 3 & 7 & 36 & 46 & 0 & 0 & $a$ & 0 & 38 \\
\hline
\end{tabular}

Revi sed: 3- 7-91

CTU R File Nane: D:/123R2/DATA/SUMSTS 90 
Appendi x 1 . (cont.)

\begin{tabular}{|c|c|c|c|c|c|c|c|c|c|}
\hline \multirow[b]{3}{*}{ DATE } & \multicolumn{4}{|c|}{ Number Trapped } & \multicolumn{5}{|c|}{ Disposition } \\
\hline & \multirow{2}{*}{$\begin{array}{l}\text { LV } \\
\text { cl i p }\end{array}$} & \multirow{2}{*}{$\begin{array}{l}\text { Ad } \\
\text { cl i p }\end{array}$} & \multicolumn{2}{|l|}{$\mathbf{N b}$} & \multirow[b]{2}{*}{ Sacri fi ced } & \multicolumn{2}{|l|}{ Trap } & Rel eased & \multirow{2}{*}{$\begin{array}{c}\text { Haul ed } \\
\text { Upstream }\end{array}$} \\
\hline & & & mark & Total & & Horts & Brood & a Dam & \\
\hline $1-3$ & 0 & 0 & 0 & 0 & 0 & $\mathbf{0}$ & 0 & 0 & 0 \\
\hline 1-8 & 0 & 0 & 0 & 0 & 0 & 0 & 0 & 0 & 0 \\
\hline I - 11 & 0 & 0 & 0 & 0 & 0 & 0 & 0 & 0 & 0 \\
\hline $1-14$ & 0 & 0 & 0 & 0 & 0 & 0 & 0 & 0 & 0 \\
\hline I - 16 & 0 & 0 & 4 & 4 & 0 & 0 & 0 & 0 & 4 \\
\hline $1-22$ & 2 & 0 & 44 & 46 & 0 & 0 & 6 & 0 & 40 \\
\hline I- 25 & 0 & 0 & 5 & 5 & 0 & 0 & 0 & ' 0 & 5 \\
\hline \multirow[t]{2}{*}{ I - 28} & 0 & 2 & 2 & 4 & 0 & 0 & 0 & 0 & 4 \\
\hline & $\cdots$ & $\cdots$ & $\cdots$ & $\cdots$ & $\cdots$ & $\cdots$ & $-\cdots$ & $\cdots$ & $\cdots$ \\
\hline J AN TOTAL & 2 & 2 & 55 & 59 & 0 & 0 & 6 & $\mathbf{0}$ & 53 \\
\hline $2-1$ & 0 & 0 & 4 & 4 & 0 & 0 & 2 & 0 & 2 \\
\hline 2- 4 & 5 & 4 & 36 & 45 & 0 & 0 & 5 & 0 & 40 \\
\hline 2- 6 & 19 & 11 & 80 & 110 & 1 & 0 & 28 & 0 & 81 \\
\hline $2-7$ & 4 & 5 & 19 & 28 & 1 & 0 & 15 & 0 & 12 \\
\hline 2- 8 & 0 & 3 & 7 & 10 & 0 & 0 & 0 & 0 & 10 \\
\hline 2- 11 & 0 & 2 & 12 & 14 & 0 & 0 & 7 & 0 & 7 \\
\hline 2- 13 & 2 & 2 & 6 & 10 & 0 & 0 & 2 & 0 & 8 \\
\hline 2- 15 & 5 & 6 & 36 & 47 & 0 & 0 & 9 & 0 & 38 \\
\hline 2- 17 & 3 & 1 & 18 & 22 & 0 & 0 & 3 & 0 & 19 \\
\hline 2- 19 & 2 & 3 & 22 & 27 & 0 & 0 & 2 & 0 & 25 \\
\hline $2-21$ & 11 & 11 & 21 & 43 & 0 & 0 & 21 & 0 & 22 \\
\hline 2- 22 & 5 & 9 & 13 & 27 & 3 & 0 & 2 & 0 & 22 \\
\hline 2- 25 & 6 & 10 & 12 & 28 & 0 & 0 & 9 & 0 & 19 \\
\hline \multirow[t]{2}{*}{ 2- 27} & 11 & 4 & 10 & 25 & 0 & 0 & 11 & 0 & 14 \\
\hline & $\cdots$ & $\cdots$ & $\cdots$ & $\cdots$ & -- & $-\cdot$ & $\cdots$ & $\cdots$ & $\cdots$ \\
\hline FEB TOTAL & 73 & 71 & 296 & 440 & 5 & 0 & 116 & 0 & 319 \\
\hline $3-1$ & 2 & 10 & 15 & 27 & 0 & 0 & 7 & 0 & 20 \\
\hline 3- 4 & 1 & 10 & 5 & 16 & 0 & 0 & 9 & 0 & 7 \\
\hline 3- 6 & 1 & 5 & 21 & 27 & 0 & 0 & 1 & 0 & 26 \\
\hline 3- a & 2 & 0 & 1 & 3 & 0 & 0 & 2 & 0 & 1 \\
\hline 3- 11 & 3 & 4 & 11 & 18 & 0 & 0 & 7 & 0 & 11 \\
\hline 3- 15 & 3 & 2 & 8 & 13 & 0 & 0 & 4 & 0 & 9 \\
\hline 3- 18 & 0 & 2 & 6 & 8 & 0 & 0 & 2 & 0 & 6 \\
\hline 3- 20 & 1 & 3 & 2 & 6 & 0 & 0 & 1 & 0 & 5 \\
\hline 3- 22 & 3 & 5 & 10 & 18 & 2 & 0 & 0 & 0 & 16 \\
\hline 3- 25 & 3 & 6 & 15 & 24 & 3 & 0 & 0 & 0 & 21 \\
\hline 3- 27 & 2 & 5 & 5 & 12 & 2 & 0 & 0 & 0 & 10 \\
\hline \multirow[t]{2}{*}{ 3- 29} & 3 & 8 & 10 & 21 & 3 & 0 & 6 & 0 & 12 \\
\hline & $\cdots$ & $\cdots$ & $\cdots$ & $\cdots$ & -- & -- & - & $\cdots$ & $\cdots$ \\
\hline MARCH TOTAL & 24 & 60 & 109 & 193 & 10 & 0 & 39 & 0 & 144 \\
\hline
\end{tabular}




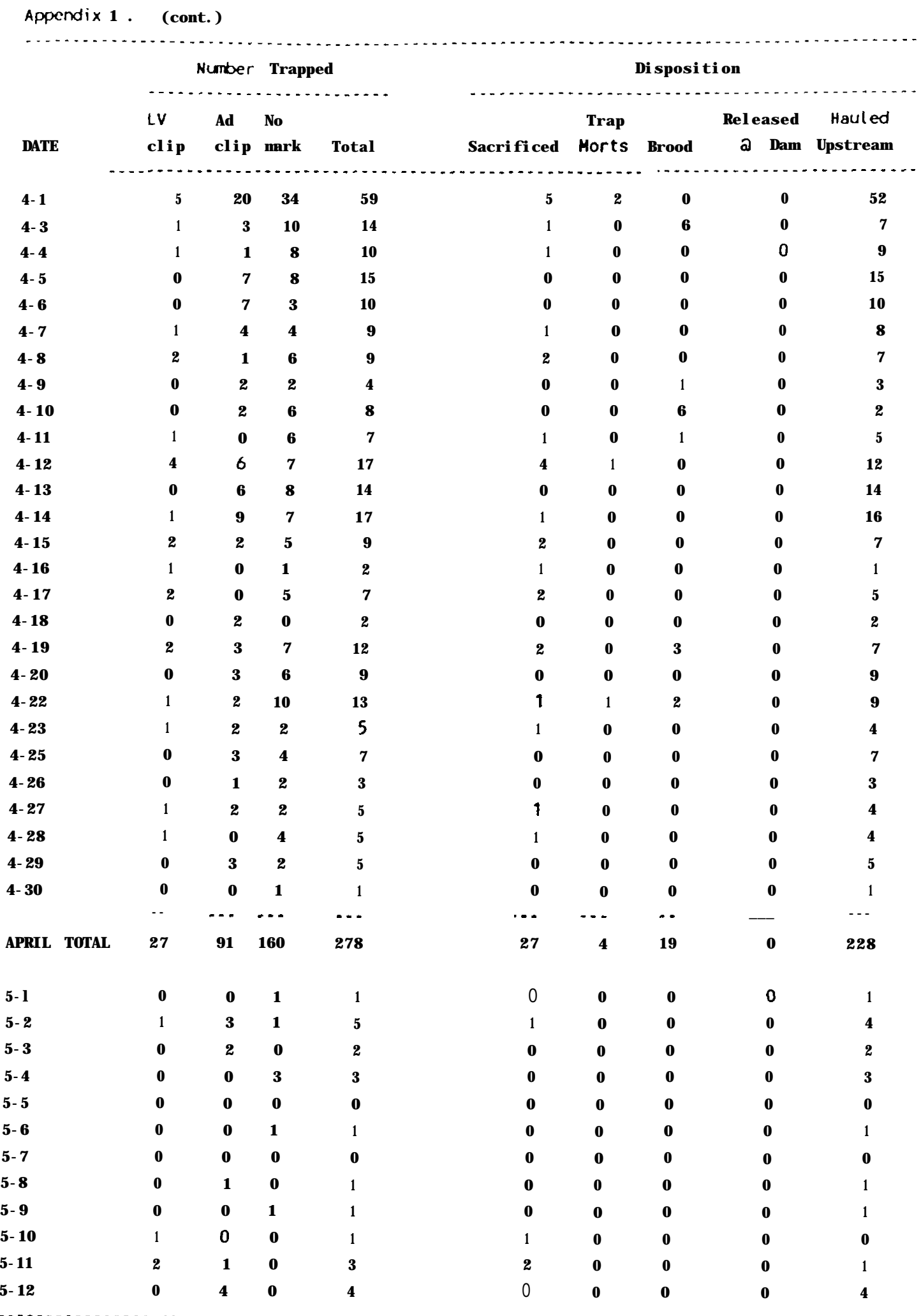

Revi sed: 6- 2-91

CTUR File Nane: D:/123R2/DATA/SUMSTS 90 


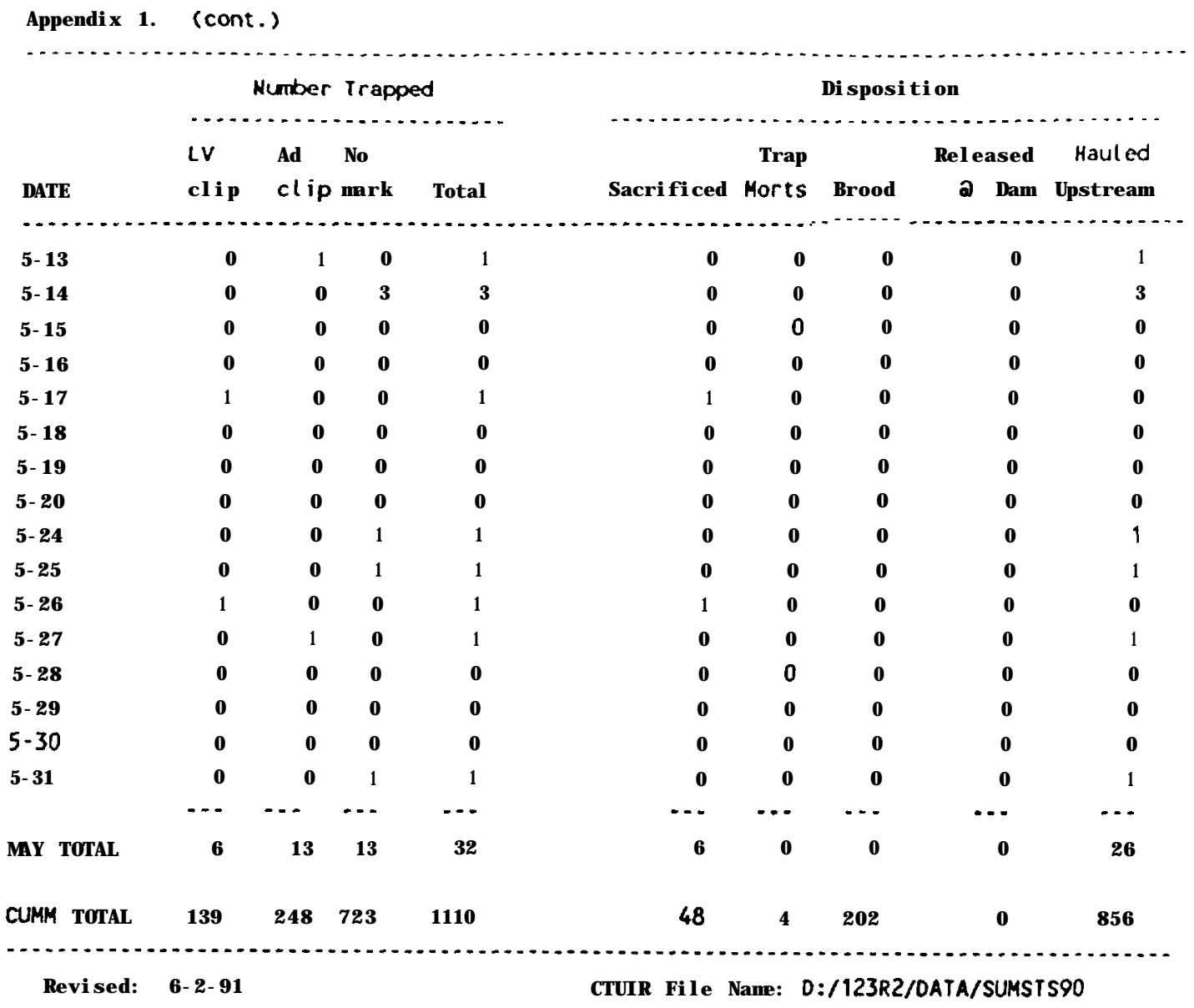


Appendix 1. Coho salmon returns to Threenile falls Dam(right bank) on the Umatilla River in 1990.

NUMBER TRAPPED

\begin{tabular}{lll} 
Adul t $\left(20^{\prime \prime}+\right)$ & \multicolumn{1}{r}{ Jack $\left(<20^{\prime \prime}\right)$} \\
\hline Ad Nb & Ad Nb \\
clip cli $\mathrm{p}$ Total clip clip Total
\end{tabular}

D SPOSI TI ON

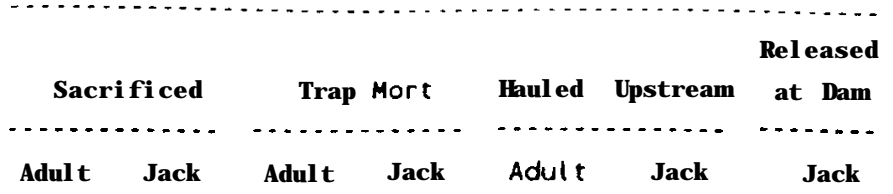

\section{$10 / 01$}

\subsection{5}

$10-10$

$10-15$

$10-18$

10- 22

10-25

10-29

10- 31

Ot TOTAL

\section{1- 2}

11- 5

11- 8

11- 9

11- 13

11- 16

11- 19

11- 21

11- 26

11- 30

NOV TOTAL

12- 3

12- 6

DEC TOTAL

J AN TOTAL

2- 6

2-15

FEB TOTAL

CUMM TOTAL

$$
\begin{array}{rrrrrr}
0 & 0 & 0 & 0 & 2 & 2 \\
0 & 0 & 0 & 0 & 2 & 2 \\
0 & 1 & 1 & 2 & 19 & 21 \\
1 & 6 & 7 & 5 & 60 & 65 \\
1 & 0 & 1 & 8 & 28 & 36 \\
0 & 5 & 5 & 2 & 10 & 12 \\
0 & 10 & 10 & 1 & 13 & 14 \\
3 & 73 & 76 & 7 & 46 & 53 \\
-- & --- & -\cdots & --- & --- & -- \\
5 & 95 & 100 & 25 & 180 & 205
\end{array}
$$

$$
\begin{array}{llllll}
16 & 110 & 126 & 5 & 68 & 73
\end{array}
$$$$
\begin{array}{lll}
2 & 24 & 26
\end{array}
$$$$
\begin{array}{lll}
5 & 68 & 73 \\
3 & 17 & 20
\end{array}
$$$$
\begin{array}{llllll}
5 & 8 & 13 & 2 & 17 & 19
\end{array}
$$$$
\begin{array}{rrrrrr}
2 & 7 & 9 & 3 & 7 & 10 \\
10 & 85 & 95 & 18 & 121 & 139
\end{array}
$$$$
\begin{array}{llllll}
3 & 12 & 15 & 2 & 23 & 25
\end{array}
$$$$
\begin{array}{llllll}
3 & 12 & 15 & 2 & 23 & 25 \\
0 & 3 & 3 & 0 & & 11
\end{array}
$$$$
\begin{array}{rrrrrr}
0 & 1 & 3 & 0 & & 11 \\
2 & 1 & 1 & 0 & 0 & 0
\end{array}
$$$$
\begin{array}{rrrrrr}
2 & 11 & 13 & 4 & 14 & 18 \\
0 & 5 & 5 & 0 & & 11
\end{array}
$$$$
\begin{array}{rrrrrr}
0 & 5 & 5 & 0 & & 11 \\
\ldots & \ldots & -\ldots & \ldots- & \ldots & -
\end{array}
$$

$\begin{array}{rrrrrrr}0 & 0 & 0 & 0 & 0 & 2 & 0 \\ 0 & 0 & 0 & 0 & 0 & 2 & 0 \\ 0 & 2 & 0 & 0 & 1 & 19 & 0 \\ 1 & 5 & 0 & 0 & 6 & 52 & 8 \\ 1 & 8 & 0 & 0 & 0 & 0 & 28 \\ 0 & 2 & 0 & 0 & 5 & 0 & 10 \\ 0 & 1 & 0 & 0 & 10 & 0 & 13 \\ 3 & 7 & 1 & 0 & 72 & 0 & 46 \\ \cdots & -. & \cdots & -\cdots & -\cdots & -\cdots & \cdots \\ 5 & 25 & 1 & 0 & 94 & 75 & 105\end{array}$

$\begin{array}{rrrrrrr}16 & 5 & 0 & 0 & 110 & 0 & 68 \\ 2 & 3 & 0 & 0 & 24 & 0 & 17 \\ 5 & 2 & 0 & 0 & 8 & 1 & 16 \\ 2 & 2 & 0 & 0 & 7 & 1 & 7 \\ 10 & 18 & 0 & 0 & 85 & 2 & 119 \\ 3 & 2 & 0 & 0 & 12 & 0 & 23 \\ 0 & 0 & 0 & 1 & 3 & 0 & 0 \\ 0 & 0 & 0 & 0 & 1 & 0 & 0 \\ 2 & 4 & 0 & 0 & 11 & 0 & 14 \\ 0 & 0 & 0 & 0 & 5 & 0 & 1 \\ --- & --- & -\cdots & -. & --- & --- & \cdots \\ 40 & 36 & 0 & 1 & 266 & 4 & 265\end{array}$

$\begin{array}{rrrrrrr}0 & 0 & 0 & 0 & 1 & 0 & 0 \\ 0 & 0 & 0 & 0 & 2 & 0 & 0 \\ -- & \cdots & \cdots & -. & \cdots & \cdots & - \\ \mathbf{0} & \mathbf{0} & 0 & 0 & 3 & 0 & 0\end{array}$

$\begin{array}{lllllll}0 & 0 & 0 & 0 & 0 & 0 & 0\end{array}$

\begin{tabular}{rrrrrrr}
0 & 0 & 0 & 0 & 0 & 1 & 0 \\
0 & 0 & 0 & 0 & 1 & 0 & 0 \\
- & $\cdots$ & $\cdots$ & -- & $\cdots$ & $\cdots$ & $\cdots$ \\
\hline 0 & 0 & 0 & 0 & 1 & 1 & 0
\end{tabular}

$\begin{array}{lllllll}45 & 61 & 1 & 1 & 364 & 80 & 370\end{array}$ 
Appendix 1. Fall chi nook sal non returns to Threenile Falls Dam (right bank) on the unatilla River in 1990.

NUMBER TRAPPED

$\begin{array}{lllll}\text { Adul t }\left(>24^{\prime \prime}\right) & \text { Jack }\left(18^{\prime \prime}-24^{\prime \prime}\right) & \text { Subjack }\left(<18^{\prime \prime}\right) \\ \ldots \text { No } & \text { Ad } \mathrm{No} & \text { Ad No }\end{array}$

DI SPOSI TI ON

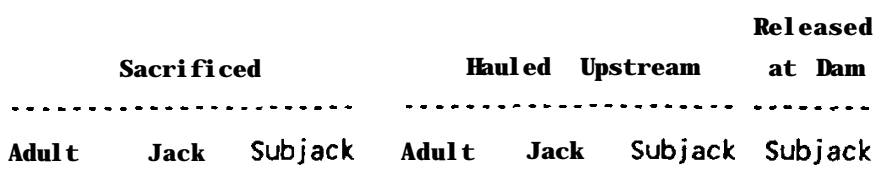

\begin{tabular}{|c|c|c|c|c|c|c|c|c|c|c|c|c|c|c|c|c|}
\hline $10-05$ & 0 & 0 & 0 & 2 & 0 & 2 & 0 & 2 & 2 & 0 & 2 & 0 & 0 & 0 & 2 & 0 \\
\hline $10-10$ & 1 & 0 & 1 & 0 & 0 & 0 & 0 & 7 & 7 & 1 & 0 & 0 & 0 & 0 & 7 & $\mathbf{0}$ \\
\hline $10-15$ & 0 & 0 & 0 & 1 & 3 & 4 & 1 & 14 & 15 & 0 & 1 & 1 & 0 & 3 & 14 & 0 \\
\hline $10-18$ & 3 & 2 & 5 & 1 & 5 & 6 & 0 & 34 & 34 & 3 & 1 & 0 & 2 & 5 & 34 & 0 \\
\hline $10-22$ & 0 & 0 & 0 & 0 & 1 & 1 & 0 & 15 & 15 & 0 & 0 & 0 & 0 & 1 & 0 & 15 \\
\hline $10-25$ & 0 & 1 & 1 & 0 & 4 & 4 & 0 & 24 & 24 & 0 & 0 & 0 & 1 & 4 & 0 & 24 \\
\hline $10-29$ & 6 & 13 & 19 & 2 & 11 & 13 & 5 & 55 & 60 & 6 & 2 & 4 & 13 & 11 & 0 & 56 \\
\hline \multirow[t]{2}{*}{$10-31$} & 26 & 21 & 47 & 5 & 17 & 22 & 2 & 109 & 111 & 27 & 5 & 2 & 20 & 17 & 0 & 109 \\
\hline & $\cdots$ & $\cdots$ & $\cdots$ & $\cdots$ & $\cdots$ & $\cdots$ & $\cdots$ & $\cdots$ & $\cdots$ & $\cdots$ & $\cdots$ & $\cdots$ & $\cdots$ & $\cdots$ & $\cdots$ & $\cdots$ \\
\hline ФT TOTAL & 36 & 37 & 73 & 11 & 41 & 52 & 8 & 260 & 268 & 37 & 11 & 7 & 36 & 41 & 57 & 204 \\
\hline 11- 2 & 52 & 52 & 104 & 2 & 15 & 17 & 0 & 135 & 135 & 52 & 2 & 0 & 52 & 15 & 2 & 133 \\
\hline $11-5$ & 15 & 11 & 26 & 3 & 6 & 9 & 1 & 59 & 60 & 15 & 3 & 1 & 11 & 6 & 0 & 59 \\
\hline 11- 8 & 6 & 13 & 19 & 0 & 7 & 7 & 0 & 42 & 42 & 6 & 0 & 0 & 13 & 7 & 0 & 42 \\
\hline 11- 9 & 6 & 2 & 8 & 1 & 1 & 2 & 0 & 13 & 13 & 6 & 1 & 0 & 2 & 1 & 0 & 13 \\
\hline $11-13$ & 35 & 40 & 75 & 1 & 13 & 14 & 1 & 84 & 85 & 35 & 1 & 1 & 40 & 13 & 0 & 84 \\
\hline 11- 16 & 3 & 3 & 6 & 1 & 3 & 4 & 0 & 11 & 11 & 3 & 1 & 0 & 3 & 3 & 0 & 11 \\
\hline 11- 19 & 1 & 2 & 3 & 0 & 1 & 1 & 0 & 3 & 3 & 1 & 0 & 0 & 2 & 1 & 0 & 3 \\
\hline $11-21$ & 2 & 1 & 3 & 0 & 0 & 0 & 0 & 0 & 0 & 2 & 0 & 0 & 1 & 0 & 0 & 0 \\
\hline $11-26$ & 7 & 6 & 13 & 0 & 1 & 1 & 0 & 4 & 4 & 7 & 0 & 0 & 6 & 1 & 0 & 4 \\
\hline \multirow[t]{2}{*}{ 11- 30} & 1 & O & 1 & 0 & 0 & 0 & 0 & 0 & 0 & 1 & 0 & 0 & 0 & 0 & 0 & 0 \\
\hline & $\cdots$ & -- & $\cdots$ & $\cdots$ & $\cdots$ & $\cdots$ & $\cdots$ & $\cdots$ & $\cdots$ & $\cdots$ & $\cdots$ & $\cdots$ & $\cdots$ & $\cdots$ & $\cdots$ & $\cdots$ \\
\hline NOV TOTAL & 128 & 130 & 258 & 8 & 47 & 55 & 2 & 351 & 353 & 128 & 8 & 2 & 130 & 47 & 2 & 349 \\
\hline $12-3$ & 0 & 0 & 0 & 0 & 0 & 0 & 0 & 0 & 0 & 0 & 0 & 0 & 0 & 0 & 0 & 0 \\
\hline 12- 6 & 0 & 2 & 2 & 0 & 0 & 0 & 0 & 0 & 0 & 0 & 0 & 0 & 2 & 0 & 0 & $\mathbf{0}$ \\
\hline \multirow[t]{2}{*}{$12-10 / 31$} & 0 & 0 & 0 & 0 & 0 & 0 & 0 & 0 & 0 & 0 & 0 & 0 & 0 & 0 & 0 & 0 \\
\hline & $\cdots$ & $\cdots$ & $\cdots$ & $\cdots$ & $\cdots$ & $\cdots$ & $\cdots$ & $\cdots$ & $\cdots$ & $\cdots$ & $\cdots$ & $\cdots$ & $\cdots$ & $\cdots$ & $\cdots$ & $\cdots$ \\
\hline OEC TOTAL & 0 & 2 & 2 & 0 & 0 & 0 & 0 & 0 & 0 & 0 & 0 & 0 & 2 & $\mathbf{0}$ & 0 & 0 \\
\hline UMMM TOTAL & 164 & 169 & 333 & 19 & 88 & 107 & 10 & 611 & 621 & 165 & 19 & 9 & 168 & 88 & 59 & 553 \\
\hline
\end{tabular}




\begin{tabular}{|c|c|c|c|c|c|c|c|}
\hline \multirow{2}{*}{$\begin{array}{c}\text { Appendix } \\
\text { DATE }\end{array}$} & 2 & \multicolumn{5}{|c|}{$\begin{array}{l}\text { Three Mile Falls Dam Trap Data Right-Bank, } \\
\text { 1990-I } 991 \text { (adults only) }\end{array}$} & \multirow[b]{2}{*}{ C:1s } \\
\hline & 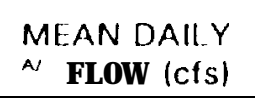 & $\begin{array}{l}\text { MEAN DAII Y } \\
\text { TEMP (C) }\end{array}$ & $\begin{array}{l}\text { SECCHH } \\
\text { D SK (M) }\end{array}$ & $\mathrm{COH}$ & $\mathrm{CHF}$ & STS & \\
\hline $10 / 10 / 90$ & 81 & 13.4 & & & 1 & 1 & \\
\hline $10 / 15 / 90$ & 99 & 12.9 & 1.1 & 1 & 0 & 1 & \\
\hline $10 / 18 / 90$ & 125 & 11.4 & 1.9 & 7 & 5 & 5 & \\
\hline $10 / 22 / 90$ & 124 & 10.7 & 1.4 & 1 & & 1 & \\
\hline $10 / 25 / 90$ & 146 & 10.7 & 1.3 & 5 & 1 & 2 & \\
\hline $10 / 29 / 90$ & 137 & 11.6 & 1.2 & 10 & 19 & 2 & \\
\hline $10 / 31 / 90$ & 150 & 11.9 & 1.2 & 76 & 47 & 3 & \\
\hline $11 / 02 / 90$ & 154 & 9.9 & 1.2 & 126 & 104 & 3 & \\
\hline $11 / 05 / 90$ & 161 & 9.7 & 1.3 & 26 & 26 & 4 & \\
\hline $11 / 08 / 90$ & 242 & 8.5 & 1.0 & 13 & 19 & 1 & \\
\hline $11 / 09 / 90$ & 239 & 9.6 & 1.1 & 9 & a & 2 & \\
\hline $11 / 13 / 90$ & 236 & 9.5 & 1.1 & 95 & 75 & 18 & \\
\hline $11 / 16 / 90$ & 213 & 7.9 & 1.0 & 15 & 6 & 6 & \\
\hline $11 / 19 / 90$ & 191 & 7.5 & 1.7 & 3 & 3 & 2 & \\
\hline $11 / 21 / 90$ & 99 & 7.1 & 1.1 & 1 & 3 & 1 & \\
\hline $11 / 26 / 90$ & 141 & 8.8 & 1.3 & 13 & 13 & 6 & \\
\hline $11 / 30 / 90$ & 182 & 5.8 & & 5 & 1 & 4 & \\
\hline $12 / 03 / 90$ & 167 & 5.1 & & 1 & & 11 & \\
\hline $12 / 06 / 90$ & 98 & 5.6 & 1.5 & 2 & 2 & 7 & \\
\hline $12 / 10 / 90$ & 104 & 6.2 & 1.4 & & & 9 & \\
\hline $12 / 13 / 90$ & 422 & 4.6 & 1.0 & & & 10 & \\
\hline$\Downarrow 2 / 17 / 90$ & 206 & 4.7 & 1.5 & & & 3 & \\
\hline $12 / 27 / 90$ & NA & .5 & & & & 6 & \\
\hline $01 / 16 / 91$ & 3140 & 4.5 & & & & 4 & \\
\hline $01 / 22 / 91$ & 779 & 2.1 & & & & 46 & \\
\hline $01 / 25 / 91$ & 377 & 2.8 & & & & 5 & \\
\hline $01 / 28 / 91$ & 199 & 2.5 & & & & 4 & \\
\hline
\end{tabular}




\begin{tabular}{|c|c|c|c|c|c|}
\hline \multicolumn{2}{|c|}{ Appendix 2} & \multicolumn{4}{|c|}{$\begin{array}{l}\text { Three Mile Falls Dam Trap Data Right-Bank, } \\
\text { 1990-1991 (adults only). }\end{array}$} \\
\hline $02 / 01 / 91$ & 190 & 3.0 & & 4 & \\
\hline $02 / 04 / 91$ & 145 & 7.2 & & 45 & \\
\hline $02 / 06 / 91$ & 181 & 8.0 & & 110 & \\
\hline $02 / 07 / 91$ & 388 & 7.1 & 1.0 & 28 & \\
\hline $02 / 08 / 91$ & 459 & 6.0 & .8 & 10 & \\
\hline $02 / 11 / 91$ & 505 & 5.7 & 1.1 & 14 & \\
\hline $02 / 13 / 91$ & 461 & 6.8 & 1.1 & 10 & \\
\hline $02 / 15 / 91$ & 2080 & 7.7 & & 47 & \\
\hline $02 / 17 / 91$ & 1770 & 7.1 & .4 & 22 & \\
\hline $02 / 19 / 91$ & 1210 & 6.5 & .4 & 27 & \\
\hline $02 / 21 / 91$ & 1300 & 8.1 & .6 & 44 & \\
\hline $02 / 22 / 91$ & 1610 & 8.1 & .4 & 27 & \\
\hline $02 / 25 / 91$ & 1020 & 6.4 & .8 & 28 & \\
\hline $02 / 27$ & 758 & 6.9 & .9 & 25 & \\
\hline $03 / 01 / 91$ & 619 & 7.1 & 1.1 & 27 & \\
\hline 03/04/91 & 721 & 8.1 & 1.0 & 16 & \\
\hline 03/06/91 & 1110 & 6.0 & .6 & 27 & \\
\hline $03 / 08 / 91$ & 945 & 6.3 & .9 & 3 & \\
\hline $03 / 11 / 91$ & 752 & 7.0 & .8 & 18 & \\
\hline $03 / 15 / 91$ & 730 & 7.0 & 1.0 & 13 & \\
\hline $03 / 18 / 91$ & 536 & 7.8 & 1.2 & 8 & \\
\hline $03 / 20 / 81$ & 491 & 8.1 & 1.6 & 6 & \\
\hline $03 / 22 / 91$ & 464 & 9.2 & 1.1 & 18 & \\
\hline $03 / 25 / 91$ & 609 & 8.5 & 1.1 & 24 & \\
\hline $03 / 27 / 91$ & 770 & 7.8 & .5 & 12 & \\
\hline $03 / 29 / 91$ & 823 & 7.5 & .9 & 21 & \\
\hline $04 / 01 / 91$ & 627 & 12.7 & 1.3 & 59 & \\
\hline $04 / 03 / 91$ & 788 & 10.2 & 1.0 & 14 & \\
\hline $04 / 04 / 91$ & 754 & 9.7 & 1.3 & 10 & \\
\hline $04 / 05 / 91$ & 704 & 10.9 & 1.3 & 15 & \\
\hline 04/06/91 & 793 & 10.3 & & 10 & \\
\hline $04 / 07 / 91$ & 773 & 10.1 & & 9 & \\
\hline $04 / 08 / 91$ & 639 & 9.5 & 1.3 & 9 & \\
\hline
\end{tabular}




\begin{tabular}{|c|c|c|c|c|c|c|c|}
\hline \multicolumn{2}{|c|}{ Appendix 2} & \multicolumn{6}{|c|}{$\begin{array}{l}\text { Three Mile Falls Dam Trap Data Right-Bank, } \\
\text { 1990-1991 (adults only). }\end{array}$} \\
\hline$n 4 / n 9 / 91$ & 5.529 & 10.3 & 1.6 & & 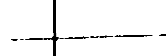 & 4 & \\
\hline $\begin{array}{l}(04 / 10 / 9 \\
04 / 11 / 91\end{array}$ & 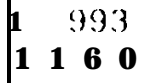 & $\begin{array}{l}9.0 \\
\text { a. } 3\end{array}$ & $\begin{array}{l}1.3 \\
1.3\end{array}$ & & $-f \cdots$ & $\mid \begin{array}{c}\ldots\} 3- \\
1\end{array}$ & $-\cdots$ \\
\hline $04 / 12 / 91$ & $\begin{array}{llll}1 & 1 & 5 & 0\end{array}$ & 9.8 & 1.9 & & & 17 & 1 \\
\hline $04 / 13 / 91$ & 1160 & 10.4 & 1.3 & & & 14 & 2 \\
\hline $04 / 14 / 91$ & 11130 & 10.8 & & & & 17 & 2 \\
\hline $04 / 15 / 91$ & 1050 & 10.0 & & & & 9 & 3 \\
\hline $04 / 16 / 91$ & 960 & 9.4 & 1.3 & & & 2 & 5 \\
\hline $04 / 17 / 91$ & 869 & 10.3 & & & & 7 & 5 \\
\hline $04 / 18 / 91$ & 807 & 11.2 & 2.0 & & & 2 & 7 \\
\hline $04 / 19 / 91$ & 700 & 12.4 & 1.6 & & & 12 & 10 \\
\hline $04 / 20 / 91$ & 648 & 13.1 & 1.6 & & & 9 & 4 \\
\hline $04 / 22 / 91$ & 657 & 14.4 & 1.9 & & & 13 & 21 \\
\hline $04 / 23 / 91$ & 684 & 14.1 & 1.3 & & & 5 & 2 \\
\hline $04 / 25 / 91$ & 787 & 11.6 & 1.3 & & & 7 & 26 \\
\hline $04 / 26 / 91$ & 673 & 10.7 & & & & 3 & 35 \\
\hline $04 / 27 / 91$ & 576 & 10.9 & & & & 5 & 39 \\
\hline $04 / 28 / 91$ & 555 & 11.1 & & & & 5 & 20 \\
\hline $04 / 29 / 91$ & 602 & 10.8 & & & & 5 & 40 \\
\hline $04 / 30 / 91$ & 810 & 12.0 & 1.6 & & & 1 & 18 \\
\hline $05 / 01 / 91$ & 823 & 12.9 & 1.9 & & & 1 & 41 \\
\hline $05 / 02 / 91$ & 791 & 13.2 & & & & 5 & 35 \\
\hline $05 / 03 / 91$ & 685 & 13.4 & 2.0 & & & 2 & 19 \\
\hline $05 / 04 / 91$ & 570 & 14.7 & 1.9 & & & 3 & 41 \\
\hline $05 / 05 / 91$ & 464 & 15.1 & 2.0 & & & 0 & 23 \\
\hline $05 / 06 / 91$ & 395 & 14.3 & 2.0 & & & 1 & 12 \\
\hline $05 / 07 / 91$ & 584 & 13.5 & & & & 0 & 3 \\
\hline $05 / 08 / 91$ & 634 & 13.6 & & & & 1 & 14 \\
\hline $05 / 09 / 91$ & 1020 & 11.7 & & & & 1 & 56 \\
\hline $05 / 10 / 91$ & 779 & 11.5 & & & & 1 & 63 \\
\hline $05 / 11 / 91$ & 687 & 12.5 & & & & 3 & 82 \\
\hline $5 / 1 \quad 2 / 91$ & 612 & 13.6 & 1.3 & & & 4 & a4 \\
\hline $5 / 13 / 91$ & 556 & 13. 0 & 1.9 & & & 1 & 40 \\
\hline
\end{tabular}




\begin{tabular}{|c|c|c|c|c|c|c|c|}
\hline Appendix & 2. & $\begin{array}{l}\text { Three Mile } \\
1990-1991\end{array}$ & $\begin{array}{l}\text { am } \\
\text { ts onl }\end{array}$ & Data & Right-Bank, & & \\
\hline $05 / 14 / 91$ & 498 & 13.4 & & & & 3 & 36 \\
\hline $05 / 15 / 91$ & 467 & 14.7 & & & & 0 & 30 \\
\hline $05 / 16 / 91$ & 499 & 15.7 & & & & 0 & 33 \\
\hline $05 / 17 / 91$ & 625 & 14.4 & & & & 1 & 28 \\
\hline $05 / 18 / 91$ & 2260 & 11.7 & .6 & & & 0 & 30 \\
\hline $05 / 19 / 91$ & 4610 & 11.5 & .3 & & & 0 & 13 \\
\hline $05 / 20 / 91$ & 12500 & 11.1 & & & & 0 & 3 \\
\hline $05 / 24 / 91$ & 2730 & 13.3 & .2 & & & 1 & 12 \\
\hline $05 / 25 / 91$ & 2130 & 12.5 & 6 & & & 1 & 30 \\
\hline $05 / 26 / 91$ & 1730 & 12.9 & .15 & & & 1 & 59 \\
\hline $05 / 27 / 91$ & 1220 & 14.3 & .3 & & & 1 & 52 \\
\hline $05 / 28 / 91$ & 884 & 15.7 & & & & & 32 \\
\hline $05 / 29 / 91$ & 650 & 16.2 & .4 & & & & 16 \\
\hline $05 / 30 / 91$ & 539 & 15.4 & & & & & 20 \\
\hline $05 / 31 / 91$ & 657 & 15.2 & & & & 1 & 15 \\
\hline $06 / 01 / 91$ & 611 & 17.0 & 1.1 & & & & 16 \\
\hline $06 / 02 / 91$ & 513 & 18.4 & & & & & 10 \\
\hline $06 / 03 / 91$ & 418 & 17.4 & .4 & & & & 7 \\
\hline $06 / 04 / 91$ & 342 & 16.5 & & & & & 13 \\
\hline $06 / 06 / 91$ & & 16.6 & & & & & 1 \\
\hline $06 / 07 / 91$ & & 16.8 & .9 & & & & 7 \\
\hline $06 / 09 / 91$ & & 17.9 & .3 & & & & 25 \\
\hline $06 / 10 / 91$ & & 19.6 & .4 & & & & 13 \\
\hline $06 / 11 / 91$ & & 20.0 & .7 & & & 1 & 10 \\
\hline $06 / 12 / 91$ & & 18.0 & & & & & 1 \\
\hline $6 / 14 / 91$ & & 16. 6 & .8 & & & & 8 \\
\hline )6/17/91 & & 17.7 & 1.2 & & & & 10 \\
\hline 6/19/91 & & 17.5 & & & & & 5 \\
\hline )6/24/91 & & 18.2 & & & & & 2 \\
\hline
\end{tabular}




\begin{tabular}{|c|c|c|c|c|c|c|}
\hline \multirow{3}{*}{$\frac{\text { Appendix } 3}{\text { DATE }}$} & \multicolumn{6}{|c|}{$\begin{array}{l}\text { Enumeration of Salmonids from video tape at Three Mile Falls } \\
\text { Dam, } 1990 .\end{array}$} \\
\hline & \multicolumn{2}{|c|}{$\mathrm{COHO}$} & \multicolumn{2}{|c|}{ FALL CHINOOK } & \multicolumn{2}{|c|}{ STEELHEAD } \\
\hline & \# UP & \# DOWN & \#UP & \# DOWN & \# UP & \# DOWN \\
\hline $10 / 09 / 90$ & & & & & 1 & \\
\hline $10 / 10190$ & 2 & 1 & & & & \\
\hline $10 / 11190$ & & & & & 6 & 5 \\
\hline \multicolumn{7}{|l|}{$10 / 12 / 90$} \\
\hline $10 / 13 / 90$ & & & 1 & & & \\
\hline \multicolumn{7}{|l|}{$10 / 14 / 90$} \\
\hline$\| 0 / 15 / 90$ & 42 & 1 & 172 & 12 & 4 & 2 \\
\hline $10 / 17 / 90$ & 7 & 4 & 2 & 1 & 1 & 0 \\
\hline $10 / 18 / 90$ & & & & & 1 & 0 \\
\hline \multicolumn{7}{|c|}{$10 / 19 / 90$} \\
\hline \multicolumn{7}{|l|}{$10 / 20 / 90$} \\
\hline $10 / 21 / 90$ & & & & & 1 & 0 \\
\hline $10 / 22 / 90$ & 5 & & 2 & 0 & 1 & 0 \\
\hline $10 / 23 / 90$ & & & 10 & 1 & & \\
\hline $10 / 24 / 90$ & 10 & 2 & 4 & 0 & 0 & 0 \\
\hline $10 / 25 / 90$ & 8 & 5 & & & & \\
\hline $10 / 26 / 90$ & 1 & & & & 1 & 0 \\
\hline $10 / 27 / 90$ & 5 & 2 & 21 & 10 & 0 & $\mathbf{0}$ \\
\hline $10 / 28 / 90$ & 3 & & 30 & 13 & 0 & 0 \\
\hline $10 / 29 / 90$ & 22 & 8 & 53 & 32 & 5 & 1 \\
\hline $10 / 30 / 90$ & 33 & 15 & 314 & 190 & 12 & 7 \\
\hline $10 / 31 / 90$ & 52 & 36 & 337 & 237 & 9 & 5 \\
\hline $11 / 01 / 90$ & 77 & 52 & 547 & 406 & 55 & 26 \\
\hline $11 / 02 / 90$ & 32 & 15 & 190 & 135 & 16 & 13 \\
\hline $11 / 03 / 90$ & 2 & 2 & 65 & 53 & 2 & 0 \\
\hline $11 / 04 / 90$ & 2 & 1 & 94 & 84 & 1 & 0 \\
\hline
\end{tabular}




\begin{tabular}{||l|c|c|c|c|c|c||}
\hline \multirow{2}{*}{ Appendix 3. } \\
Enumeration of Salmonids from video tape at Three Mile Falls \\
\hline $11 / 05 / 90$ & 20 & 24 & 105 & 87 & 0 & 0 \\
\hline $11 / 06 / 90$ & 3 & 1 & 103 & 86 & 1 & 0 \\
\hline $11 / 07 / 90$ & 3 & 0 & 92 & 78 & 0 & 0 \\
\hline $11 / 08 / 90$ & & & 49 & 33 & & \\
\hline $11 / 09 / 90$ & 16 & 4 & 178 & 113 & 9 & 3 \\
\hline $11 / 10 / 90$ & 30 & 10 & 270 & 132 & 5 & 0 \\
\hline $11 / 11 / 90$ & 16 & 5 & 129 & 57 & 23 & 10 \\
\hline $11 / 12 / 90$ & 28 & 7 & 136 & 77 & 1 & 0 \\
\hline $11 / 13 / 90$ & 13 & 7 & 51 & 46 & 1 & 1 \\
\hline $11 / 14 / 90$ & 24 & 19 & 56 & 52 & 1 & 0 \\
\hline $11 / 15 / 90$ & 34 & 35 & 69 & 48 & 1 & 0 \\
\hline TOTALS & 454 & 256 & 2,927 & 1,983 & 158 & 73 \\
\hline & & & & & & \\
\hline & & & & & & \\
\hline & & & & & & \\
\hline & & & & & & \\
\hline
\end{tabular}




\title{
EVALUATI ON OF J UVEN LE FI SH BYPASS FAC LI TI ES AT MATER D VERSI ONS IN THE UHATILLA RIVER
}

\author{
I nt eri m Progress Report \\ Apri I 1991 - Sept enber 1991 \\ Prepared by \\ M chael C. Hayes \\ Suzanne H Knapp \\ Anthony A $\mathbf{N}$ gro
}

\begin{abstract}
Oregon Department of Fi sh and $\mathrm{V} / \mathrm{I}$ dl i fe
P. 0 Box 59

2501 SW Fi rst Ave.

Portl and, OR 97207
\end{abstract}

\section{Cooper at ors}

Oregon Department of Fi sh and Vill dl i fe

Conf ederated Tribes of the Unati I la Indian Reservati on

Prepared for

Jerry Bauer, Proj ect Manager

U. S. Depart ment of Energy

Bonnevi I I e Power Admi ni strati on

Di vi si on of Fi sh and $\mathrm{V}^{\text {il }} \mathrm{dl}$ i fe

P. O. Box 3621

Portl and, OR 97208

Proj ect 89-024-01

Cont ract No. DE-B179-89BP01385

January 1992 


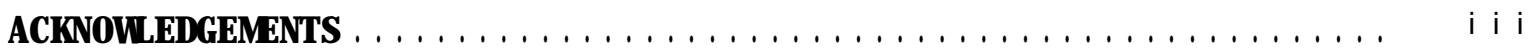

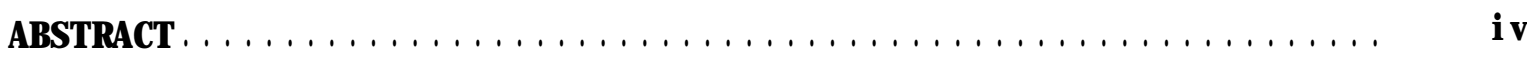

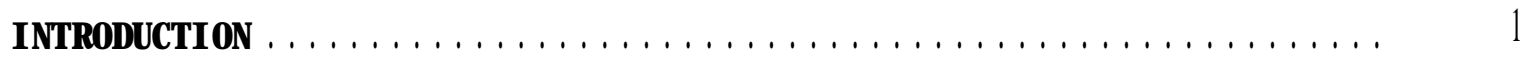

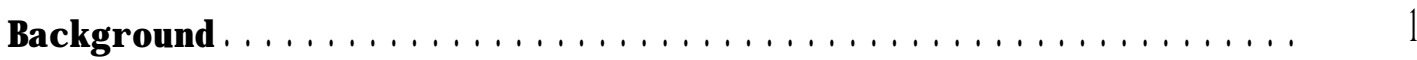

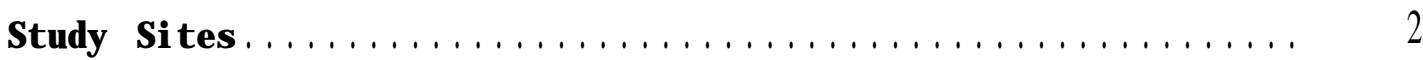

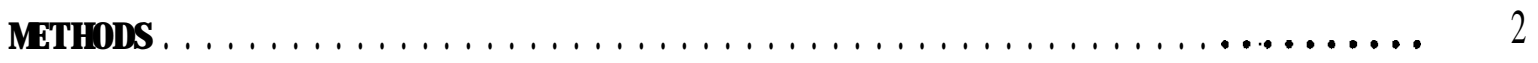

Three MIe Fal Is DamJ uveni I e Fi sh Bypass Facility Eval uation. 2

Screen In jury ........................... 5

Bypass Pi pe and outfal I I nj ury Test ............... 6

Headgate Injury Test ........................ 6

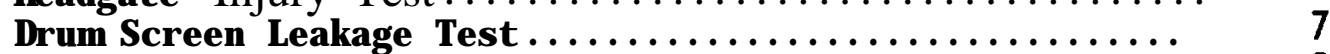

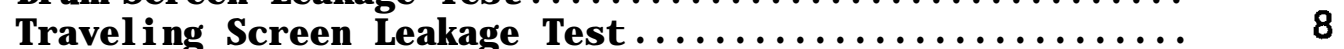

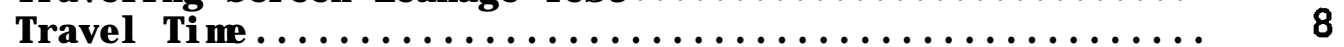

Juvenile Passage........................... 8

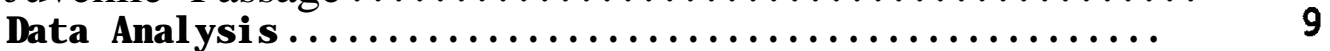

Acti vi ti es at Mexuel I, West I and, and Col d Spri ngs Di versi on Dans $\ldots \ldots \ldots \ldots$

Maxuel I Di versi on Dam ........................... 10

West I and Di versi on Dam ........................... 11

Cold Springs Diversion Dam ..................... 11

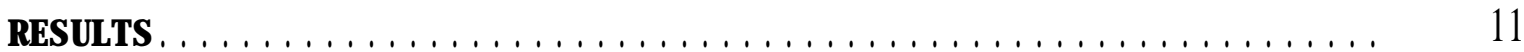

Three M I e Fal Is Dam J uveni I e Fi sh Bypass Faci I ty Eval uati on. 11

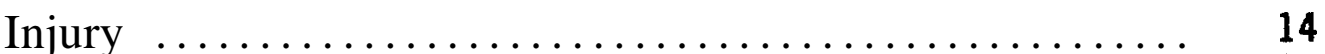

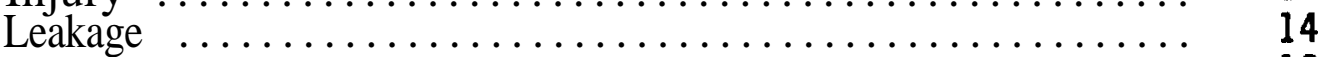

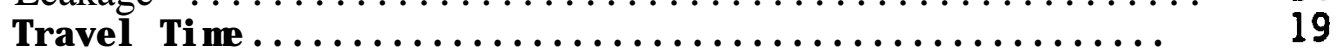

Passage ................................. 22

Acti viti es at Maxuel I, Westl and, and

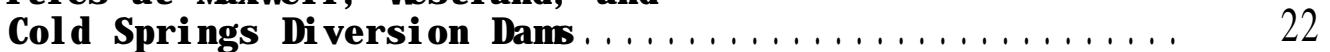

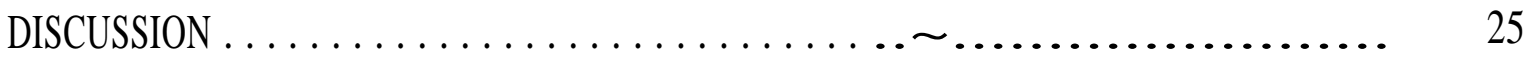

Three MI e Fal Is Dam Eval uati on $\ldots \ldots \ldots \ldots \ldots \ldots \ldots \ldots \ldots \ldots \ldots$

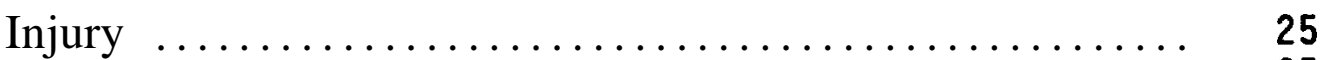

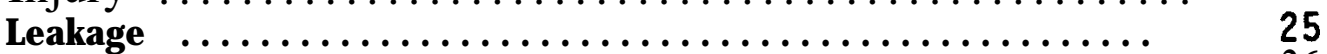

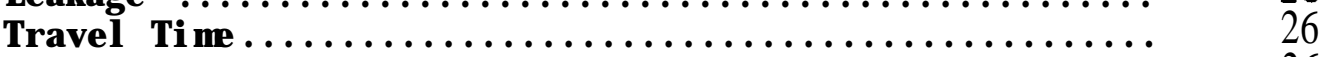

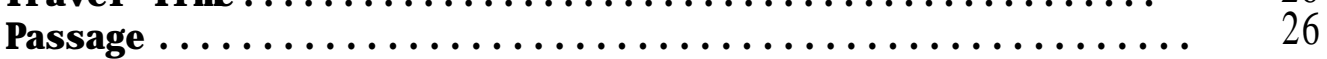




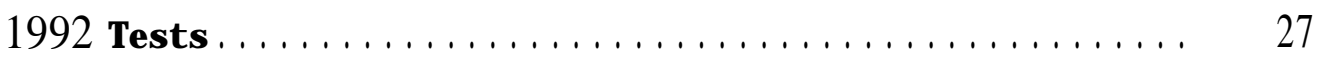

Operati onal and Structural Problens at Three Mle Fal Is Dam.. 27

Sampl i ng Equi pment $\ldots \ldots \ldots \ldots \ldots \ldots \ldots \ldots \ldots \ldots \ldots \ldots \ldots, \quad 27$

Travel i ng Screen $\ldots \ldots \ldots \ldots \ldots \ldots \ldots \ldots \ldots \ldots \ldots \ldots \ldots \ldots, \quad 29$

Operating Criteria.................................. 29

Acti vi ti es at Mexuel I, Westl and, and

Col d Spri ngs Di versi on Dans $\ldots \ldots \ldots \ldots \ldots \ldots \ldots \ldots \ldots, 30$

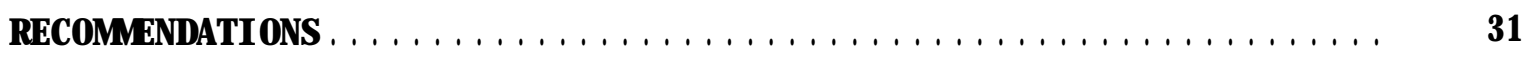

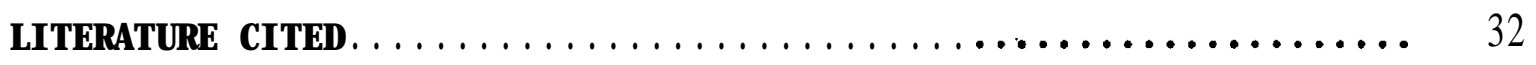

APPENDIX A..................................... 34 


\section{ACKNOVLEDGEMENTS}

We greatl y appreciated the efforts of our fi el d crew i n conducting the acti viti es of the study. Specifically, we thank Robert Muel ler for his assi stance in di recti ng study activiti es and in desi gni ng the Col d Spri ngs trap. We al so thank Jill Berry, Eri c Veach, Kathy Terrel I, Ti a Jensen and David Guard of our seasonal staff $f$ or thei $r$ work in the fi el d performing the eval uati on. We appreci ated the assi stance of Rosanna Tudor and J i I Berry i n summarizi ng the data. We thank Jerry Franke of the West Extensi on Di st ri ct for hi s support and cooperation. We al so thank Gerry Rown of the Conf ederat ed Tri bes of the Unati Il a I ndi an Reservati on and his techni ci ans for nonitoring our test $f i$ sh at the $M$ nthorn accl $i$ mation pond and $f$ or thei $r$ assi stance in I oadi ng fi sh to be used in tests. We al so appreci ated the assi stance of Ray $\mathrm{HII}$ and Wide Bergeson of the I rrigon Hatchery in provi di ng us with fall chi nook.

We extend our appreci ati on to Jay Mercotte and Jerry Bauer of the Bonnevi I l e Power Admi ni strati on for thei $r$ assi stance wi th contracting of f unds. We thank Mary Buckman, Enery Whgner, and Phi I Howel I for thei $r$ critical revi ew of the manuscri pt. 


\section{ABSTRACT}

We report on our effort from April through Septenber 1991 to eval uate the j uveni I e fi sh bypass faci I ity i $n$ the West Extensi on I rrigation Di st ri ct Canal at Three MIe Fal Is Dam on the Unatilla Ri ver. We al so report on $\mathrm{j}$ uvenile sal moni d out mi grati on through the east bank adult fi sh I adder i n 1990 , and through the bypass facility in 1991. We i ncl ude i nf ormation on prel i mi nary acti vi ti es to prepare for fut ure eval uations at Mexwel I, Westl and, and Col d Springs di versi on dans. Tests at Three MI e Fal I s Dam showed that races of spri ng and fal I chi nook sal non (Oncorhynchus tshawytscha) and sumer st eel head (Uncorhynchus mykiss) were not i nj ured during passage through the enti re fi sh bypass facility. We al so observed no si gni fi cant l eakage of chi nook sal non fry through the drum screen system with screeni ng ef fi ci ency approachi ng $100 \%$. Some i mpi ngenent of fry and subyearlings was observed on the secondary travel ing screen because of unf avorable hydraul i cs and i nsuf $f$ i ci ent spray water at one l ocation. Fi sh moved freel y through the upper screening facility and general I y moved more rapi dl y duri ng ni ghtti me tests. Fi sh movenent was del ayed i $n$ the I ouer bypass out $f$ al I at $f$ I ous of $5 \mathrm{cfs}$, but qui ckened when fl ous were increased to 25 cfs. A though novenent of fish in the facility was nore rapi d at ni ght, the migrati on of river-run sal moni ds (probably coho and chi nook sal non) showed a di sti nct di urnal peak. Passage through the east bank I adder showed that sone fi sh movenent was correl at ed wi th hi gher ri ver fl ous. We of fer recommendati ons for struct ural and operati onal i mprovenents i $n$ the West Extensi on I rri gati on Di stri ct Canal j uveni l e fi sh bypass facility at Three MIe Fal Is Dam We fabri cated and partly tested collection systens for the $\mathrm{j}$ uveni le fi sh bypass faciliti es at Maxuel I, Westl and, and Cold Spri ngs di versi on dans to be used i n fut ure eval uations. The pri mary probl em encountered with the Maxuel I trap was a backwash eddy that stranded fi sh. Prel i mi nary moni tori ng of fyke net operati on at the Westl and Di versi on Dam showed that the net worked wel I and onl y requi red mi nor modifications. Duri ng 1992, we will conti nue tests at Three Mle Fal Is Dam and prepare for eval uati on acti vi ti es at Westl and Dam i 1993. 


\section{NTRODUCTI ON}

\section{Backgr ound}

The Nort huest Power Pl anni ng Counci I's ( NPPC) Col unbi a Ri ver Basi n Fi sh and Vil dl i fe Program (1987) cal I ed for the i mprovenent of anadronous $f i$ sh passage faciliti es at i rrigation di versi on projects in the Unatilla Ri ver Basi $n$ i $n$ the form of passage i mprovements (Secti on 1403, Measure 4. 2). Under contract with the Bonnevi Il e Power Admi ni stration (BPA) and i n cooperati on with the Confederated Tribes of the. Unatilla Indi an Reservation (CTU R) and fi sh and wild i fe agenci es, the U.S. Bur eau of Recl anati on ( USBR) devel oped and carried out - a program to i mprove fish passage facilities at Unatilla River di versi on dans. State- of-the-art passage facilities at Three Mle Fal Is Dam uere the first to be constructed, fol I oued by Maxwel I and Col d Spri ngs di versi on dans. West I and Di versi on Dam passage faciliti es were reconstructed under the di recti on of the Oregon Department of Fi sh and $\mathrm{WI} / \mathrm{dl}$ i fe (ODFW. Passage facilities at Stanfi el d Di versi on Dam are currentl y in the desi gn phase by ODW staff. New screeni ng facilities are intended to prevent j uveni l e sal moni ds from entering the i rrigati on canal s by gui di ng them unharmed back to the river from which they were di verted. Eval uation of the passage i mprovenent proj ects at the fi ve maj or di versi on dans on the Unatilla Ri ver was suggested i $n$ A Comprehensi ve PI an for Rehabi I i tation of Anadronous Fi sh Stocks in the Unati I a Ri ver Basi n (Boyce 1986).

Construction of si $\mathrm{m} /$ ar fish passage and protection facilities at maj or (Phase I) i rri gati on di versi ons i n the Yaki ma Ri ver Basi n, Whshi ngt on has al so been funded by BPA and USBR under Secti on 803 (b) of the NPPC s Col unbi a Ri ver Basi n Fi sh and Vil dl i fe Program (NPPC 1987). Eval uati ons of the effecti veness of these fish screeni ng facilities on the Yaki m River have been carri ed out by $\mathrm{Nei}$ tzel et al . (1985, 1987, 1988, 1990a, 1990b) and Hosey \& Associ ates (1988, 1989, 1990). We consi dered thei $r$ experi ences when desi gni ng eval uations of $f i$ sh screening facilities in the Unatilla Ri ver basi $n$.

We began the fi rst year of our eval uati on of $\mathbf{j}$ uveni l e fi sh bypass facilities in the Unatili a Ri ver at Three MI e Fal I s Damin Novenber 1989. During this period, we operated and eval uated the efficiency of the $j$ uveni I e fi sh bypass system i $n$ the West Extensi on I rrigati on Di stri ct (VEI D) Canal . I mprovenents were. made to the fish bypass collection facilities, a system was devel oped to col l ect $\mathrm{j}$ uveni l e sal noni ds at the bypass outfal $\mathrm{I}$, and prel i mi nary i nf or nati on on $j$ uveni l e fi sh passage condi $t i$ on was col l ected ( Knapp and Whrd 1990). A subsequent report (Knapp 1991) descri bed our approach to and preparatory activities for conducting the second year of the study.

In thi s report we descri be our progress toward addressi ng second year st udy obj ecti ves. These st udy obj ecti ves were to (1) eval uate the passage of j uveni I e sal moni ds through the bypass system in the VEI D Canal facility at Three MIe Fal Is Dam i ncl uding the eval uation at desi gn fl ow . of i nj ury and mortal ity rates, and passage of $j$ uveni $l e$ sal moni ds through and over the screens, and (2) perform prel i mary acti vi ti es that noul d faci l i tate passage eval uati ons at the Maxuel $I$, Westl and, and Col d Spri ngs di versi cns dans i n coming years. 


\section{Study Si tes}

A descripti on of the Three MIe Fal Is Dam and associ ated VEI D Canal and fi sh screeni ng faci I ti es is in our first annual progress report (Knapp and Whrd 1990). A descri pti on of the Mexuel I and Westl and dans uas i ncl uded i n the second annual progress report (Knapp 1991). Col d Spri ngs Di versi on Dam i s l ocated at ri ver mile 29.2 and reconstructi on of the ol d juveni I e fi sh screening facility was compl eted in 1990. Components of the new facility and associ at ed canal structure i ncl ude a trashrack, 10 rotary drum screens, a bypass chanber and out let, and a canal check and wasteway structure. A I si tes are I ocated on the l ower Unatilla Ri ver (Fi gure 1) and a schentic di agramill ustrates the fi sh bypass facility at Three MIe Fal Is Dam (Fi gure 2).

\section{METHODS}

Three MIe Fal Is Dam J uveni I e Fi sh bypass Faci l ity Eval uati on

The eval uati on of the $j$ uveni le $f i$ sh bypass facility at Three Mle Fal Is Dam consi sted of several di fferent tests to eval uate vari ous components of the facility at designed operating criteria and flow The pri mary tests conducted were the screen inj ury, bypass pi pe and outfal I i nj ury, and drum screen l eakage tests. Secondary tests eval uated headgate i nj ury and travel ing screen l eakage. We conducted these tests with different species or races (si zes) of chi nook sal non (Oncorhynchus tshawytscha) and sumer steel head (Oncorhynchus myki ss) i n Apri I and May of 1991. Methods were descri bed i n detai I i n Knapp (1991).

We conducted al I i nj ury tests usi ng yearling spring chi nook sal mon and sumer steel head and subyearling fal l chi nook sal mon. For the headgate i nj ury test we used $f i$ sh saved from previ ous tests that were in good condi ti on. Drum screen I eakage was tested with fall chi nook sal mon fry. These speci es were sel ected because they are present in the Unatilla River system Al fish used in the screen i nj ury tests were freeze-branded with a uni que group brand and hel d i n separate contai ners for 48 to 72 hours to al l ow the brand to set and the fish to accli mate. For the screen l eakage test, control fall chi nook sal mon fry were marked with bi snark brown dye to differenti ate them from the treat ment groups and $\mathrm{pl}$ aced i $\mathrm{n}$ an aerated contai ner for one hour to al $\mathrm{l}$ ow the dye to set. Marked groups nere hel d i n I arge tanks suppl i ed wi th pumped ri ver water from the canal. In addi tion, fl oati ng net pens uere used to hol d fi sh i $n$ the canal headworks area or in the river when necessary. Mbre detai led i nf ormati on on test fi sh, brandi ng, and the hol di ng system i s avai I abl e i n Knapp (1991).

We determi ned fi sh condi ti on for al I i nj ury tests usi ng descal ing criteri a devel oped by the U. S. Army Corps of Engi neers (Neitzel et al. 1985) and descri bed i $n$ Knapp (1991). Fi sh condition was based on the percentage of scal e loss i $n$ each of $f i$ ve desi gnated sections per si de of fish. Fish were cl assified as "heal thy" (scal e l oss c or $=3 \%$ per section), "parti ally descal ed" ( scal e l oss > 3\% but < 40\% per secti on), or "descal ed" (cumul at i ve scal e l oss $>$ or $=40 \%$ i $n$ any two sections). We al so recorded observat $i$ ons of other i nj ury types such as cuts, brui ses, eye or head i nj uri es, and torn oper cul uns. 

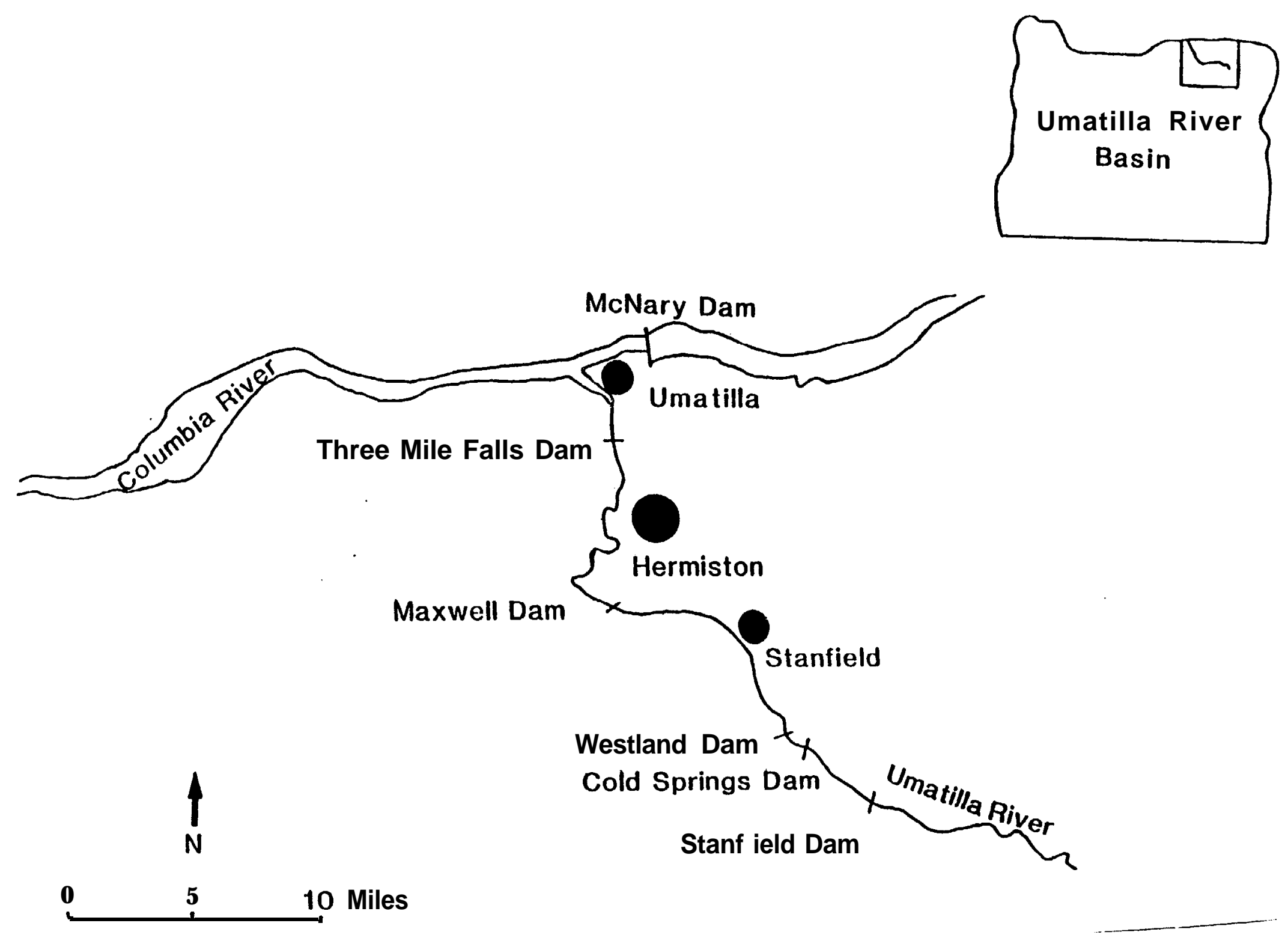

Figure 1. Location of diversion dams on the lower Umatilla River, Oregon 


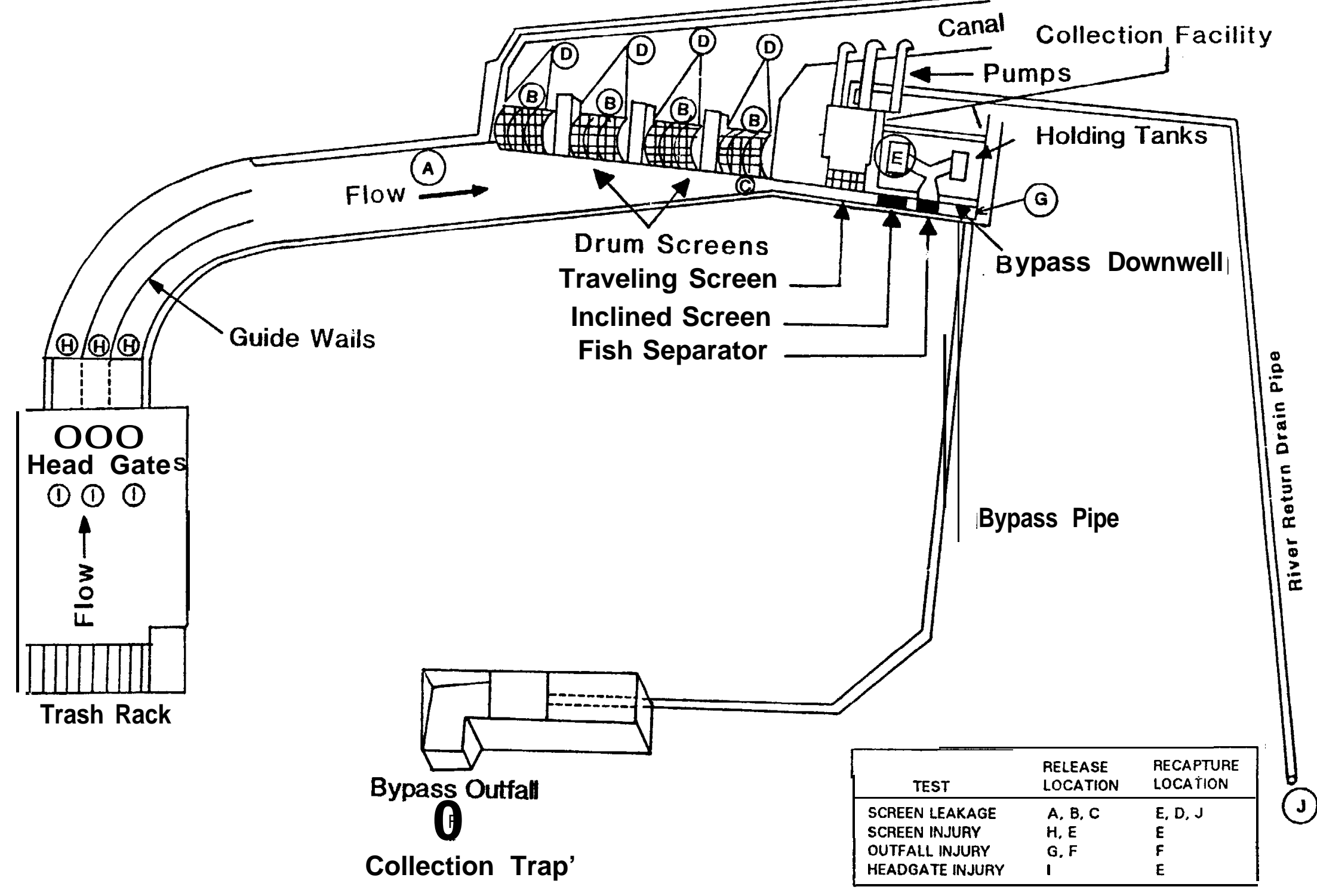

Figure 2. Schematic of the juvenile bypass facility at Three Mile Falls Dam including sampling locations for release and recapture of fish. 
Screen I nj ury

To eval uate i nj ury and nortal ity rates associ ated with the drum screens, we rel eased repl $i$ cate groups of heal thy, freeze-branded $f i$ sh upstream of the drum screens and recapt ured them at the bypass col l ecti on facil ity (treat ment). We al so rel eased repl i cate groups of heal thy fi sh (cont rol ) di rectly i nto the col l ection facility (sample tank) to al l ow us to eval uate i nj ury caused by the col I ecti on and handli ing process. A I recapt ured fi sh uere exami ned for descal i ng and other i nj uri es.

We conducted tests with spring and fal I chi nook sal mon during the day and at ni ght and summer steel head during the day from 23 April to 9 May 1991. We conducted tests on three different dates with up to three replicates tested each day. Treat nent' and control fi sh were rel eased on the same day. Each test consi sted of approxi matel y three, 100-fi sh groups for each speci es or race of test fish. We rel eased treatment groups at approxi matel y 0900 hours and 2100 hours, respecti vel y, for three consecuti ve 24-hour peri ods. Treat ment groups were rel eased i medi at el y fol l owi ng the rel ease of the control groups i nto canal fl ows rangi ng from 116 cfs to 149 cfs $\mathbf{1 7 7 \%} 99 \%$ of maxi mum desi gn canal flow). Occasi onal l y, control groups were pool ed, creati ng onl y one group per day. A $10 \%$ subsampl e from each repl i cate group was exami ned for condi $t i$ on bef ore rel ease to ascertai $n$ pre-rel ease condi $t i$ on. These subsample fi sh were not ret urned to thei $r$ groups.

Treat ment groups were rel eased i medi at el $y$ bel ow the headgates i $n$ each of three fl une secti ons in the canal headworks ( Fi gure 2). Groups of control fish were rel eased di rectl y i nto the col l ecti on faci li ty sample tank and handl ed during exami nation in the same manner as the treatment fish. We fol l owed operation criteria for a sampling node when capt uring rel eased test fish in the coll ection facility. Thi s i ncl uded the i nstal I ati on of sampl ing equi pnent ( orifice plate, i ncli ned screen, fish separat or), and operation of the travel ing screen and pumpback pumps, and the proper setting of wei $r$ gate posi ti ons and headworks wat er I evel s (USBR 1989). On occasi on, we parti al I y opened the 21-i nch di aneter drai $n$ pi pe gate to ret urn water to the river in I i eu of pump operation.

We recapt ured treat ment $\mathrm{fi}$ sh in the sampl e tank at the bypass col I ecti on facility (Fi gure 2). Fi sh were crouded and renoved from the tank every hour to determine travel ti me and prevent tank crouding. Treat ment fi sh were capt ured for at I east 96 hours after rel ease to al l ow suffici ent ti ne for a 95\% recovery. Fork I engths. were taken from a random sel ecti on of cont rol and treat nent fi sh.

Ri ver run fish col l ected during the eval uati on were separated from test fi sh and returned to the river. If necessary, we anesthetized al I fish to separate test from $r i$ ver run fi sh. We exami ned test fi sh i medi atel y upon recapt ure or transferred them to the hol di ng contai ners for I ater processi ng. Anesthetized river run and test fi sh were pl aced i $n$ a hol di ng tank to recover from the anesthetic and then rel eased into the bypass downuel I. A I test fish were $\mathrm{pl}$ aced i $\mathrm{n}$ an anest het i c trough and anest het i zed wi th Fi nquel (MS222). Fi sh condi ti on was determi ned and recorded on descal ing forms. We exam ned fi sh for descaling i $n$ the col I ecti on facility which i ncl uded an overhead canopy for protecti on fromthe weather, and a hi gh pressure sodi um I i ght to 
mai nt ai $\mathbf{n}$ consi stent I i ght i ng condi ti ons. for use in secondary tests.

Fi sh i n good condi ti on were ret ai ned

Bypass Pi pe and Outfal I Injury

To eval uate i nj ury and nortal ity rates associ ated with the bypass pi pe and bypass outfal I, we rel eased repl i cate groups of f reeze-branded heal thy fi sh into the bypass downwel I, recapt ured them in the bypass outfal I collection trap ( f l oating net pen) and examined the fi sh for descal ing and ot her i nj uri es (treatment). Wh al so rel eased repl i cate groups of fi sh di rectl y i nto the bypass outfal I col lection trap to al I ow us to eval uate i nj ury caused by the col lection and handling process (control).

We conducted tests from 16 Apri I to 31 May 1991. General Iy, we conducted tests on three different dates for each speci es or race of test fi sh and at bypass fl ous of $5 \mathrm{cfs}$ and $25 \mathrm{cfs}$. Each test consi sted of three, approxi natel y 100-fi sh groups. A $10 \%$ subsampl e from each treatment and control group was exami ned pri or to rel ease to ascertai $n$ pre-rel ease condition. These subsampl ed fi sh were not ret urned to thei $r$ groups.

The operati on criteri a for bypass fl ow were adhered to when performing the tests. Thi s i ncl uded the instal I ation of the restrictive orifice plate for 5 cfs flow and the concurrent operation of the travel ing screen and pumpback pumps (USBR 1989). Weir gate posi ti ons for both fl ow regi mes were al so properly set according to operating criteria. During the 25 cfs tests, we i nstal I ed a bypass channel stopl og to reduce fl ous duri ng control rel eases and subsequent net positioning. The stopl og was renoved to achi eve a full 25 cfs fl ow bef ore rel easing the treat nent groups.

We rel eased control fi sh i nto the net pen i medi atel y bef ore rel easi ng treat ment $\mathrm{fi} h$ at the bypass channel wei $r$ crest upstream of the downwel $\mathrm{I}$. Therefore, both groups were in the net pen si mul taneousl y during the recapt ure i nterval. To capt ure the maj ority of the test fi sh, the net pen remai ned i $n$ position for about one hour, We retrieved the net pen after the prescribed i nterval, and retrieved control $f i$ sh and test fi sh, pl aci ng them in contai ners for i medi ate exami nation. Ri ver $r$ un $f i s h$ were rel eased to the river. We examined fish for i nj ury in the same manner as in the screen i nj ury test. Fi sh were al lowed to recover fromthe anesthetic i $n$ net pens placed in the river prior to rel ease.

Headgate I nj ury

To eval uate i nj ury and mortal ity associ ated wi th passage through the headgates, we rel eased groups of previ ousl y used, good condi ti on fi sh upstream of the headgates, recapt ured them at the col I ecti on faci lity, and exami ned them for inj ury or descaling. We used the resul ts fromtreatment fish in the screen i nj ury tests that were rel eased downstream of the headgates as a control. During testing, we fol I owed normal canal operati ons and operating criteria for a sampling mode at the collection facility (USBR 1989). A I three headgat es were ful I y open. 
Three dayti me tests and two ni ghtti ne tests for spring chi nook sal non were conducted from 30 Apri I to 2 Myy 1991; and t wo dayti ne tests and two ni ghtti ne tests for fall chi nook sal mon were conducted on $\mathbf{7}$ and 8 May 1991. The number of fi sh rel eased in each test ranged from 77 to 190. We di d not subsample test fish to determine pre-test fish condition, but for purposes of anal ysis we assumed that al I fish began the test in good condition. Fi sh uere rel eased in separate groups in front of the headgates (Fi gure 2).

Fi sh were recapt ured in the bypass col l ecti on facility at hourly i nt erval s, and exami ned for descal i ng and ot her i nj ury, fol I oui ng the same procedure used in the screen i nj ury test. We recorded $f i$ sh condi ti on, and ti ne of rel ease and recapture. After processing, we rel eased the fi sh back to the river.

\section{Drum Screen Ceakage Test}

To eval uate passage of $\mathbf{j}$ uveni $\mathbf{l} e$ sal noni ds $\mathbf{t h r o u g h}$ (leakage) and over ( i mpi ngenent) the drum screens, we rel eased treat ment groups of $f$ al I chi nook sal non fry upstream from the screens and recapt ured them ei ther in fyke nets pl aced i medi atel y behi nd the screens in the VEI Canal or in the bypass col I ecti on facility ( Fi gure 2). We al so rel eased groups of bi snark-brown dyed control fish in the fyke net mouth to obtai $n$ an esti mate of net col lecti on and retention ef $\mathrm{i}$ ci ency. An esti mate of bypass col l ecti on ef fici ency was obtai ned by rel easing groups of control fish in the bypass channel and recapt uring them in the sample tank at the collection facility. We al so noni tored fi sh passage over the screens during tests to esti mate rol l over caused by i mpi ngement. Because sal monid fry are not a normal contingent of the j uveni l e outmigrati on, our test fry were easi l y di scernabl e.

Tests were perforned at a canal fl ow of 74 to 78 cfs from 5 April to 10 Apri I 1991. Three tests were made, each during mid-norni ng and separat ed by 48-hour peri ods. The 48-hour i nterval was necessary to al I ow fi sh from one group to $\mathrm{cl}$ ear the system before rel ease of the next group, si nce test fish groups coul d not be di fferenti ated.

Because of our i nability to desi gnate separate groups for each test, we rel eased a si ngl e 300-fi sh treatnent group upstream of the screens, and a si ngl e 300-fish control group in the bypass channel on each test day. Control fi sh were al so rel eased behi nd each of the four screens in the net nouth in separate 75-fish group. Each test was desi gned to comprise $900 \mathrm{fi}$ sh for three days, for a total of 2, 700 fry.

To capt ure test fish in the col l ection facility, we fol l oued the operation criteri a for sampl ing. Thi s i ncl uded the i nstal I ati on of bypass channel sampl ing equi pnent, operation of the travel ing screen, openi ng of the ri ver return drai $n$ pi pe ( pumpback pumps could not be operated wi th fyke nets i $n$ pl ace), and proper setting of wei $r$ gate positions and headuorks water I evel s (USBR 1989).

Fyke nets were pl aced behi nd the screens bef ore rel eases. The fyke nets were moni tored for approxi matel y 48 hours af ter rel ease to capt ure control fish and any test fi sh that l eaked past or rolled over the screens. At 4 to 6- hour i nterval s during this 48-hour period, we exami ned the contents of the 
fyke net by i ndi vi dual Iy rai si ng the nets, renovi ng the contents of the cod end, and pl aci ng the contents i $\mathrm{n}$ buckets. The nets were cl eaned wi th water suppl i ed from the travel ing screen spray water pump and i medi at el y I owered back into pl ace. We col lected fry from the sampl e tank in the bypass collection facility every hour. Data on river run fish collected in the sample tank were recorded, and then the fish were ret urned to the river.

We recorded the numbers of fry retrieved (treat ment and control) from each fyke net and from the hourly sample tank crouding. During the tests, we moni tored the drum screens for any i ndi cati on of fry i mpi ngenent and documented numbers of rol l over $\mathrm{f} i \mathrm{sh}$. We recorded l engt hs of al I treat nent fish that passed through or over the screens. We recorded I engths from subsampl es of treatment and control fi sh.

Travel ing Screen Leakage Test

To determine if I eakage was occurring at the secondary travel ing screen, ue i nstal led a fyke net at the termi nus of the river return pi pel i ne (Knapp 1991). Any fi sh I eaking past the screen when the sl ui ce gate to the ri ver ret urn drai $n$ pi pe was open woul d be event ual ly capt ured i $n$ the fyke net. We pl anned to retrieve the contents of the fyke net on a hourl y basis.

We were unable to devi se a method to capt ure fi sh i mpi nged on the travel ing screen during pumpback pump operation. However, we made two fi sh rel eases i $n$ the bypass channel to determine if we could di rectly observe i mpi ngenent of $f$ al $I$ chi nook sal mon fry on the travel ing screen. On 24 April, we rel eased 110 fry i nto the bypass channel. The two 10 cf s pumpback pumps uere in operation with the sl ui ce gate cl osed. On 2 May we made another rel ease of fry into the bypass channel with the river return drai $n$ pi pe opened nore than 12 i nches on the pi pe stem We adj usted the pi pe stem down to 9i nches to reduce turbul ence, and hydraul i condi ti ons appeared si mi ar to condi ti ons during pumpback pump operation.

\section{Travel Ti ne}

We exami ned fi sh novenent during the screen i nj ury. and bypass out $f$ al $I$ tests to determine if the fish bypass facility could del ay fish migration. The ti ne of rel ease and recapt ure was recorded to ascertai $n$ novement rates through the facility. In the screen inj ury test, we esti mated travel ti me through the screen faci I ity by cal cul ating the ti ne to recapt ure $50 \%$ (mean

travel ti ne) and $95 \%$ of the test fish. In the bypass outfal I test, we esti nated fish travel ti ne through the I over bypass and outfal I by computing the total number of test $f i$ sh recapt ured in one hour.

\section{J uveni I e Passage}

Fi sh passage i nf or mati on on wi l and hatchery-reared sal noni ds rel eased upstream from Three MI e Fal Is Dam was obtai ned during tests from 5 Apri I to 10 April, and from 23 April to 9 May 1991. We sampled hourly al I fi sh entering the fish bypass facility and recorded the numbers of wid and 
hatchery fish present. Because of the I arge number of fish noving through the facility, speci es of $f i$ sh nere conbi ned.

The numbers of $j$ uveni I e sal noni ds movi ng through the east bank fi sh I adder at Three M I e Fal Is Dam were docunented in the spring of 1990 usi ng vi deo cameras $\mathrm{pl}$ aced i $\mathrm{n}$ the east I adder vi ewi ng wi ndow to record adul $\mathbf{t}$ passage. Vi deo tape i nf or mati on was noni tored peri odi cal I y from 23 March to 7 J une 1991. These vi deo tapes were revi ewed to determi ne the number and ti $\mathbf{m}$ ng of dounst ream ni grati ng juveni I e sal moni ds usi ng the east bank I adder. I ndi vi dual speci es coul d not be determ ned.

\section{Data Anal ysi s}

We used anal ysis of vari ance (ANOVA) to test the hypothesi s that the rel at $i$ ve conditi on of control and treatment fish were equal i $n$ al $I$ i nj ury test s. Sources of vari ati on tested i $n$ each ANOVA were treat ment versus control, and ti me of day (day or ni ght) or fl ow ( 5 cfs or 25 cfs). We chose as our si gni ficance I evel a $p$ val ue of $<I Q$ A $I$ testing uas completed using the General Li near Model Procedure in the SAS program for personal conputers (SAS I nsti tute I nc 1990).

I nj ury Esti mates: For purposes of anal ysi s, we cal cul at ed pre-test condi ti on ( from subsampl es) and post-test condi ti on ( from cont rol or treatment test fish) of fish observed as percentages of recapt ured i nj ured fish (the sum of partl y descal ed, descal ed, and other i nj ured fi sh). We then cal cul at ed net i nj ury rate as the difference bet ween pre-test and post-test condi tion.

We computed a 95\% conf i dence i nterval about the net inj ury rate for each treat nent and control group. In the headgate i nj ury test, no subsampl es to measure pre-test condi ti on were obtai ned. Ther ef ore, we assuned the condi ti on of treatment fish was equal to zero, meani ng that no i nj ured fi sh were present.

Screen Effici ency Esti mates: We eval uated the abi I ity of the drum screens to prevent fish fromentering the i rrigation canal and gui de $f i$ sh that encounter the drumscreens into the bypass. We esti nated screen effici ency for each test and for al I tests combi ned. We conbi ned al I data from the vari ous tests to compensate for differences in test si ze and theoretical ly, i n the number of $\mathrm{fish}$ encount ering the screen.

Esti mates of screen effi ci ency were corrected for bypass col l ecti on effici ency $\left(E F F_{b c}\right)$ and net capt ure effici ency $\left(E F F_{n c}\right)$. We assuned net retention to be equal to net efficiency, gi vi ng it a val ue of 1 . The formul a for esti mating screen ef $\mathrm{i}$ ci ency $\left(E F F_{S C}\right)$ was:

$$
E F F_{S C}=1-\frac{\text { Xnet }}{E F F_{n C} N}
$$

where

$$
x_{\text {net }}=\text { number of } \mathrm{fish} \text { rel eased upstream of the screens and }
$$


caught in the nets

$\mathrm{N}=$ an esti mate of the total nunber of fish encountering the screens ( $i t$ my be less than the actual number of fish rel eased:

$$
N=\frac{\text { Xnet }}{\text { EFFnc }} t \frac{\mathbf{X b c}}{E_{\text {bF }}}
$$

where

$\mathrm{Xbc}=\mathrm{the}$ number of $\mathrm{fi}$ sh rel eased upstream of the screens and caught in the bypass collection facility

$$
\begin{aligned}
E F F n c & =\frac{n n c}{N_{n c}} \\
E F F_{b c} & =\frac{n b c}{N_{b c}}
\end{aligned}
$$

where

$$
\begin{aligned}
& n_{n c}=\text { the number rel eased i } n \text { the net mout } h \text { and caught in the net } \\
& \mathrm{N}_{\text {nc }}=\text { the number rel eased in the net nouth } \\
& \mathrm{nbc}=\text { the number of } \mathrm{fi} \text { sh rel eased i } \mathrm{n} \text { the bypass channel and } \\
& \text { caught in the bypass col lection facility } \\
& N_{\text {bc }}=\text { the number rel eased in the bypass channel }
\end{aligned}
$$

Acti viti es at Maxuel I, Westl and, and Col d Spri ngs Di versi on Dans

\section{Maxuel I Di versi on Dam}

We fabricated a bypass trap for the Maxuel I Damfacility using an i ncl i ned pl ane desi gn (Knapp 1991). We subsequentl y used the bypass trap at the Maxwel I screening faci lity on 6 J une 1991 to test for suitability and ef fecti veness in capt uring fish wi thout inj ury. Before testing, we constructed a $4 \times 4$-i nch wooden frame and installed two I/2-ton hoi sts to I ift and I ower the trap in $\mathrm{pl}$ ace in the bypass downuel I. We positioned the trap and channel wei $r$ boards so that approxi natel y IO cfs bypass fl ow entered the trap. The trap angle was adj usted with the use of the pi vot rod front entrance assenbly to achi eve a sui table, nont urbul ent water fl ow i nto the li ve box wi thout i mpinging fish.

We rel eased one 25- $\mathrm{fi}$ sh group of marked subyearling fal I chi nook sal non upstream of the bypass near the midd e drum screen, and three 25- $\mathrm{fi}$ sh gr oup i $\mathrm{n}$ the bypass channel. We retrieved the fish from the trap I i ve box, exami ned them for condi ti on, and docunent ed observable problens wi th trap operation. Bypass channel rel eases were retrieved in 2 mi nutes; the drum screen rel ease was retrieved in 30 minutes. 
Wést I and Di versi on Dam

A fyke net and fl oating I i ve box assenbly for use i $n$ the $j$ uveni le pond at the Westl and Damfi sh facili ty uas fabri cated (Knapp 1990). Duri ng mid-J une, we depl oyed the modi fi ed fyke net in the $j$ uveni' ' $i$ e hol di ng pond to test the efficiency and effectiveness of the net in capturing fish. We instal led the fyke net in stop I og grooves at the upstream end of the pond. A $2 \times 12$ - i nch board was pl aced across the pond to access the I i ve box. The pond i nf I ow was adj usted to $4 \mathrm{cfs}$. We rel eased one 35- fi sh repli cate of dyed subyearling fal I chi nook sal mon downst ream of the bypass wei $r$ and a second 17- $\mathrm{i}$ sh repl $\mathrm{i}$ cate upstream of the wei $r$. Subyearli ngs were retri eved from the I i ve box 5 to 10 mutes after rel ease and exami ned for condi ti on. We docunent ed operation and desi gn defici enci es for fut ure modi fi cations.

\section{Col d Spri ngs Di versi on Dam}

We desi gned and fabri cated an al umi num i ncl i ned pl ane trap for the bypass at Col d Springs Dam The desi gn i ncorporated feat ures of the bypass channel, bypass downwel I, maxi mum desi gn bypass fl ow and avai l abl e struct ures for trap al i gnment and depl oyment. The i ncl i ned pl ane was 7.6-ft I ong by 2.5-ft wi de wi th 3. 0-ft si dewal Is that served as spl ash guards and i ncorporat ed a 90degree turn at the out l et. The entrance width was 3.9-ft tapering to an outl et wi dth of 2.5-ft. A 2.5-ft I ong by 1.3-ft wi de $x$ 2. 0 - ft deep I i ve box ( 47 gal capacity) was wel ded to the downstream end of the trap. Perforated sheet ing cont ai ni ng I/ 8-i nch di aneter, staggered hol es (40\% open) was used for part of the fl oor and I i ve wel I to di ssi pate 18 cfs. Tho sets of $1 / 2$-inch thi ck I ifting brackets were wel ded to the si de walls, and the enti re trap was const ructed of 3/16-inch sol i d al umi num supported on sections of l-inch angl e i ron. Thi s trap will be tested in 1992 and testing of the Cold Springs j uveni I e fish bypass facility will occur in 1993-1994.

\section{RESULTS}

Three MIe Fal Is Dam Juveni l e Fi sh Bypass Facility Eval uati on

Lengths of fish used were si milar for control and treat nent $f i s h$ in al I tests (Fi gures 3 and 4). The summer st eel head used were gradeouts that i ncreased the range of $\mathrm{fi}$ sh l engths tested. Sumer steel head I engths averaged $150 \mathrm{~mm}$ (fork I ength) and ranged from $35 \mathrm{~mm}$ to $225 \mathrm{~mm}$

Screen In jury: Fi sh i nj ury rates of $\mathbf{j}$ uveni I e sal moni ds novi ng past the drum screens and i nto the bypass channel during day and ni ght tests uere not si gnifi cantly greater than control fish for spring chi nook sal non ( $F=0.63$, $P>0.77), f(a l l$ chi nook sal non ( $F-1.12, P>0.42)$ or sumer st eel head $(F=1.91$, P>0. 28) ( Tabl e 1). The hi ghest nean net i nj ury percentages were found for spri ng chi nook sal non dayt i me control s $(8.7 \%$ and sumer steel head dayt i me controls (7.2\%). Mbst "other" i nj uries to fi sh consisted of eye or head danage. 

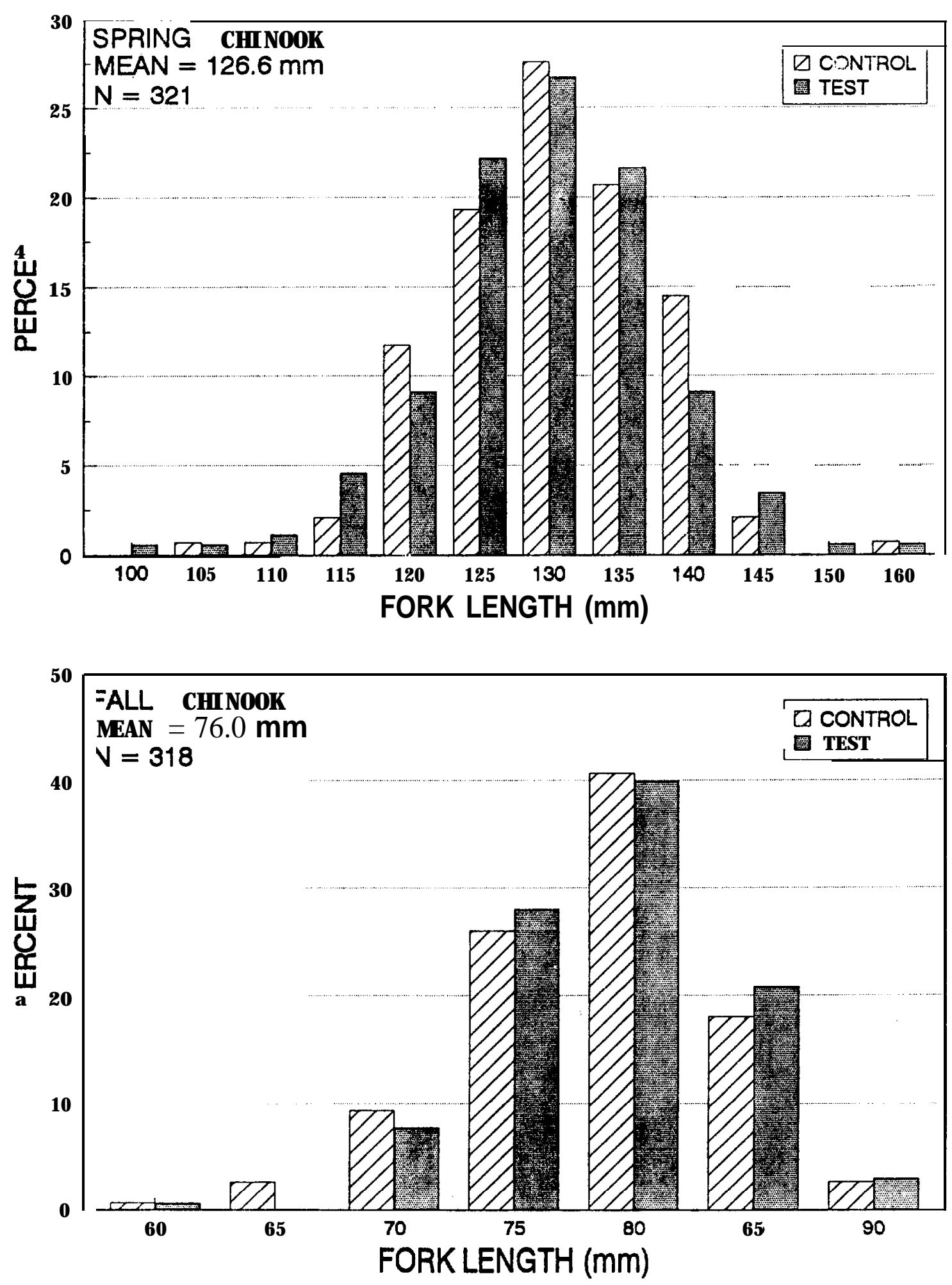

Fi gure 3. Length frequency di stributi on of spring chi nook sal non and fall chi nook sal non used i $n$ i nj ury tests at Three M I e Fal Is Dam Unat i Ila Ri ver, 1991. 


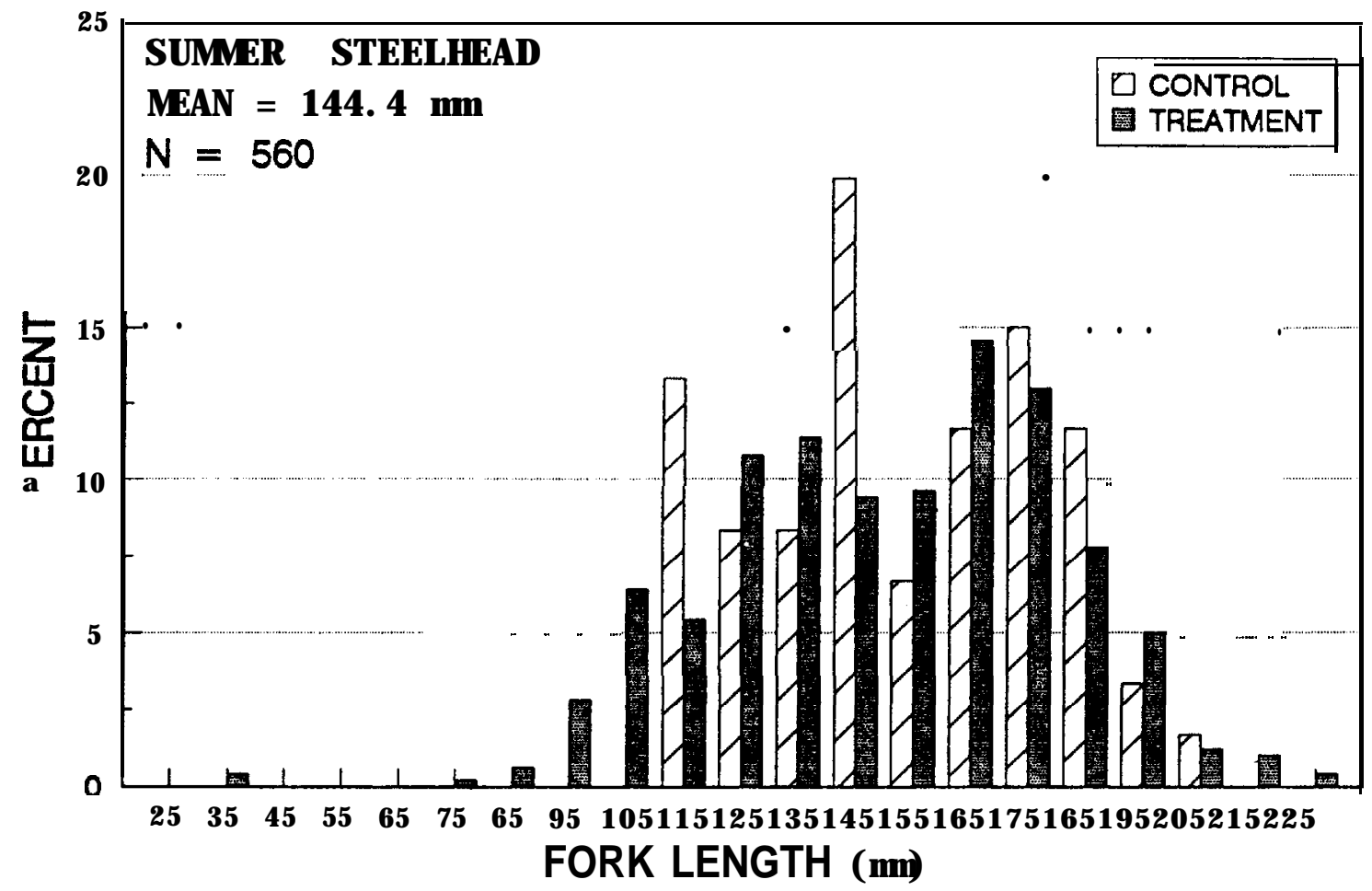

Fi gure 4. Length frequency di stri buti on of sumer steel head used i $n$ i nj ury tests at Three MIe Fal Is Dam Unati I I a Ri ver, 1991.

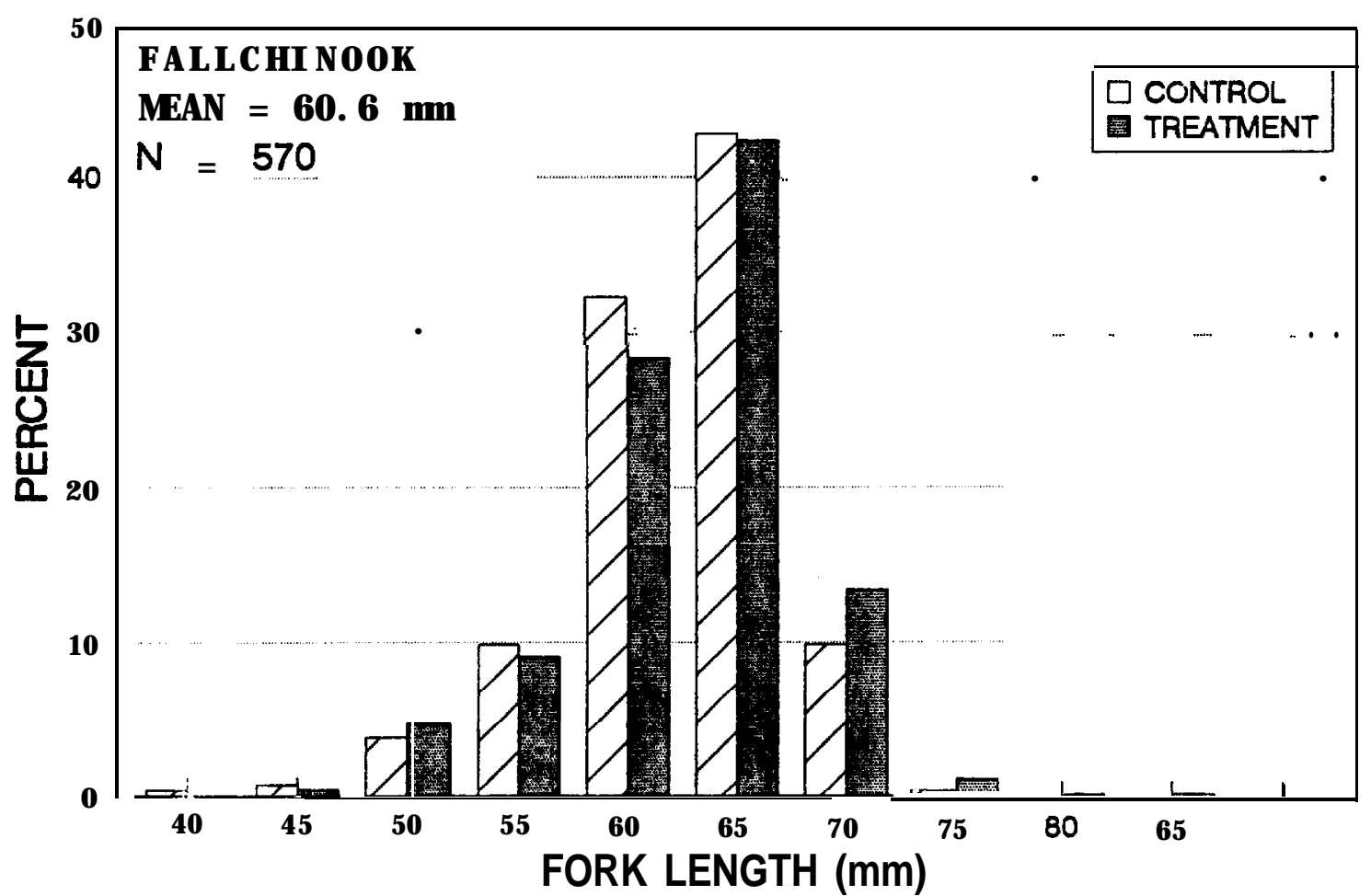

Fi gure 5. Length frequency di stri buti on of $f$ al $I$ chi nook sal mon used in the screen I eakage tests at Three MI e Fal Is Dam Unati I I a Ri ver, 1991. 
In j ury

Bypass Outfal I Injury: Condi ti on of fi sh ret urning to the ri ver through the bypass pi pe and outfal $\mathrm{I}$ at fl ows of $5 \mathrm{cfs}$ and 25 cfs was not si gni ficant ly different than control fi sh for spring chi nook sal non ( $F=1.71, P>0.19)$. There was a hi gher probability of a si gnifi cant difference for fal l chi nook sal mon $(F=1.79, P>0.11)$ and sumer st eel head $(F=1.86, P<0.10)($ Tabl e 2). However, the maj or source of vari ati on was caused by a day ef fect $(F=4.47, P t 0.02)$ for $f$ al I chi nook and a day*fI ow i nteracti on ( F-5. 42, $P<0.01)$ f or st eel head, and was not attri butable to the bypass outfall. Generally, spring chi nook sal non showed hi gher net i nj ury rates ( $r$ ange of $12 \% 30 \%$ than ei ther $f$ al I chi nook sal non or summer steel head, but this occurred for treat ment and control fi sh. The percentage of "other" i nj uries for fal I chi nook sal mon vere hi gher i $\mathbf{t}$ thi s test than for al I other tests and speci es, and ranged from $4 \%$ to $13 \%$ The maj ority of these i nj uri es vere from predators and parasites or were stressi nduced nortalities and were not caused by the testing procedure. These nortal i ti es compri sed approxi matel y $\mathbf{8 0} \%$ of the "other" cat egory for both $\mathrm{fl}$ ow regi mes, and were a result of hol di ng fi sh for a prol onged períod during fl ooding in I ate May.

Treat ment fish in the outfal I i nj ury test were recapt ured with I ess success than in the screen inj ury test. Cenerally, I ess than $60 \%$ of the rel eased fish were recapt ured, and for summer st eel head the recapt ure percentage was I ess than $30 \%$

Headgate I nj ury: Li mited testi ng suggested that i nj ury rates of $\mathrm{j}$ uveni le sal moni ds that travel ed past the headgates were not si gnifi cantly different than control fi sh for spring chi nook sal non ( $F=1.00, P>0.49$ ) or fal I chi nook sal non ( $F=0.50, P>0.85$ ) (Table 3$)$.

\section{Leakage}

Drum Screen Leakage: The overal I mean ef $i$ ci ency rata of $f i$ sh passing the drum screens wi thout I eaki ng into the canal was esti mated at $99.8 \%$ ( Tabl e 4). Esti mated mean ef fici ency rates for each of the four drum screens showed little vari ability and ranged from $99.6 \%$ - $99.9 \%$ In addi ti on, screen ef $\mathrm{i}$ ci ency esti nates for an i ndi vi dual drum screen were si mi ar anong days. Effici ency of the bypass col lecti on system averaged $77.0 \%$ whil e net ef $\mathrm{i}$ ci ency averaged $82.3 \%$ of $900 \mathrm{fi}$ sh rel eased upstream of the screens, onl y $6 \mathrm{fi}$ sh passed through the screens. Because we observed one rollover i mpi nged fish, we suspected that rollover my have been the cause for the net capt ure of the other five fish. During the test peri od, canal fl ous were approxi matel y $50 \%$ of maxi mum desi gn fl ow and ranged from 74.0 cf s to 78.0 cf s.

The l engt hs of $\mathrm{f} i \mathrm{sh}$ rel eased upstream of the screens and caught in the fyke nets were $60,60,62,64$, and $66 \mathrm{~mm}$ These I engt hs were near the average I ength of $f$ al $I$ chi nook. sal mon used for both control and treat nent tests ( Fi gure 5). 
Table 1. Mean percentages of partly descal ed, descal ed, and other i nj ured fi sh; net i nj ury rate; and 95\% conf $i$ dence i nterval s for the screen i nj ury test at Three M I e Dam Fal I s, Unati I l a Ri ver, 1991 (subsample val ues are in parentheses; $\mathbf{N}=$ number of test repl i cates).

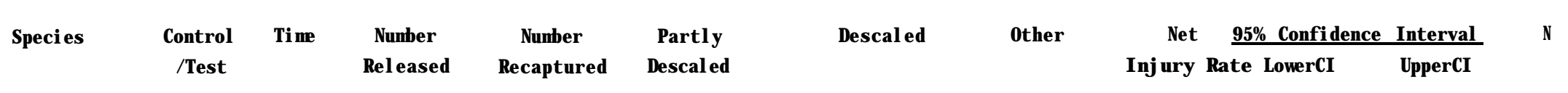

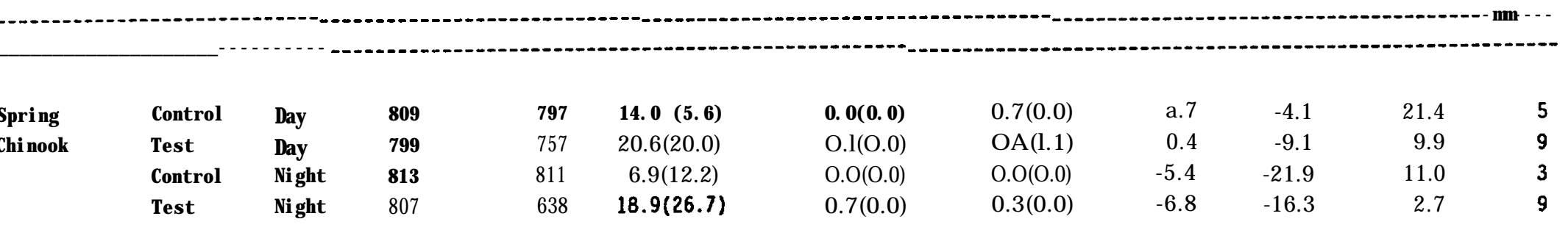

ज

\begin{tabular}{|c|c|c|c|c|c|c|c|c|c|c|c|}
\hline Fal I & Control & Day & 806 & 803 & $7.2(3.0)$ & $0, \alpha(0,0)$ & $0.1(0.0)$ & 4.3 & -1.5 & 10.1 & 5 \\
\hline \multirow[t]{3}{*}{ Chi nook } & Test & Day & 700 & 513 & $7.2(1.3)$ & $0, \alpha 0.0)$ & $0, \alpha 0.0)$ & 5.9 & 1.4 & 10.5 & 8 \\
\hline & Control & $\mathbf{N}$ ght & 790 & 795 & $3.2(8.0)$ & $0, \alpha 0,0)$ & $0.0(0,0)$ & -4.9 & -12.3 & 2.6 & 3 \\
\hline & Test & Ni ght & 808 & 715 & $5.6(2.2)$ & $0,0(0,0)$ & $0.2(0.0)$ & 3.7 & -0.6 & 8.0 & 9 \\
\hline Sumer & Control & Day & 324 & 321 & $28.7(21.5)$ & $0.0(0.0)$ & $0.7(0.0)$ & 7.2 & -13.0 & 27.4 & 4 \\
\hline St eel head & Test & Day & 322 & 145 & $35.5(32.1)$ & $0.0(0.0)$ & $0.0(0.0)$ & 3.2 & -13.4 & 19.7 & 6 \\
\hline
\end{tabular}


Tabl e 2. Mean percentages of partly descal ed, descal ed, and other i nj ured fi sh; net i nj ury rate; and 95\% conf i dence i nterval s for the outfal I i nj ury test at Three M I e Fal Is Dam Unati I I a Ri ver, 1991 (subsample val ues are in parent heses; $\mathbf{N}=$ number of test repl i cates).

\begin{tabular}{|c|c|c|c|c|c|c|c|c|c|}
\hline Speci es & Control & Fl ow & Nunber & Number & Partl y & Descal ed & other & Net I nj ury & 95\% Confi dence Interval \\
\hline & / Test & & Rel eased & Recapt ur ed & Descal ed & & & Rate & Lower C $\quad$ Upper C \\
\hline
\end{tabular}

$\begin{array}{llllllllrrrrrr}\text { Spri ng } & \text { Control } & 5 & \mathbf{5 8 9} & 576 & 55.8(36.2) & \mathbf{0 . 0 0 . 0 )} & \mathbf{0 . 0}(\mathbf{0 . 0}) & 19.7 & 3.8 & 35.6 & 7 \\ \text { Chi nook } & \text { Test } & 5 & 624 & 355 & 69.1(40.5) & 0.4(0.0) & 0.4 & (0.0) & 29.5 & 13.6 & 45.4 & 7 \\ & \text { Control } & 25 & 352 & 302 & 48.3(36.8) & 0.0(0.0) & 0.0 & (0.0) & 11.6 & -9.5 & 32.6 & 4 \\ & \text { Test } & 25 & 330 & 173 & 63.9(41.5) & 3.5(0.0) & 0.9 & (0.0) & 26.9 & 5.8 & 48.0 & 4\end{array}$

a

\begin{tabular}{|c|c|c|c|c|c|c|c|c|c|c|c|}
\hline Fal I & Control & 5 & 693 & 673 & $55.0(58.3)$ & $2.1(2.6)$ & $4.0 \quad(0.0)$ & 0.2 & -11.5 & 11.9 & 9 \\
\hline \multirow[t]{3}{*}{ Chi nook } & Test & 5 & 748 & 357 & $46.8(61.8)$ & $1 . \mathrm{B}(\mathrm{O} .0)$ & $8.6 \quad(0.0)$ & -4.5 & -16.2 & 7.2 & 9 \\
\hline & Control & 25 & 637 & 601 & $33.1(15.3)$ & 1.J(O.0) & $6.6(18.2)$ & 7.3 & -4.4 & 19.0 & 9 \\
\hline & Test & 25 & 688 & 487 & $24.1(17.8)$ & $2.1(0.0)$ & $12.7(17.8)$ & 3.4 & -8.3 & 15.1 & 9 \\
\hline Sumer & Control & 5 & 810 & 823 & $27.7(31.1)$ & O.l(O.0) & $0.0(0.0)$ & -3.3 & -12.5 & 5.9 & 9 \\
\hline \multirow{2}{*}{ St eel head } & Control & 25 & 810 & 723 & $15.8(20.0)$ & $0.0(0.0)$ & $0.0(0.0)$ & -4.2 & -13.5 & 5.0 & 9 \\
\hline & Test & 25 & 801 & 240 & $32.1(26.7)$ & $0.0(0.0)$ & $0.4 \quad(0.0)$ & 5.8 & -3.4 & 15.0 & 9 \\
\hline
\end{tabular}


Table 3. Mean percentage of partly descal ed, descal ed, other i nj ured fish, net-i nj ury rate and $95 \%$ conf $i$ dence i nterval s for the headgate i nj ury test at Three M I e Fal Is Dam Unati I la Ri ver, 1991 ( subsample val ues are in parentheses; $\mathbf{N}=$ number of test repl i cates).

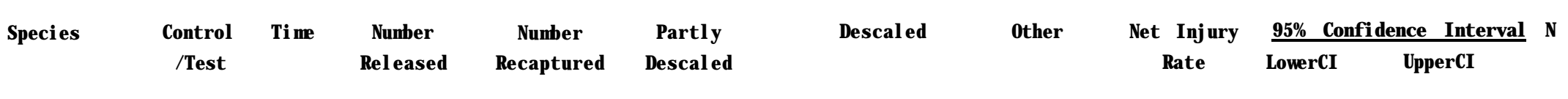

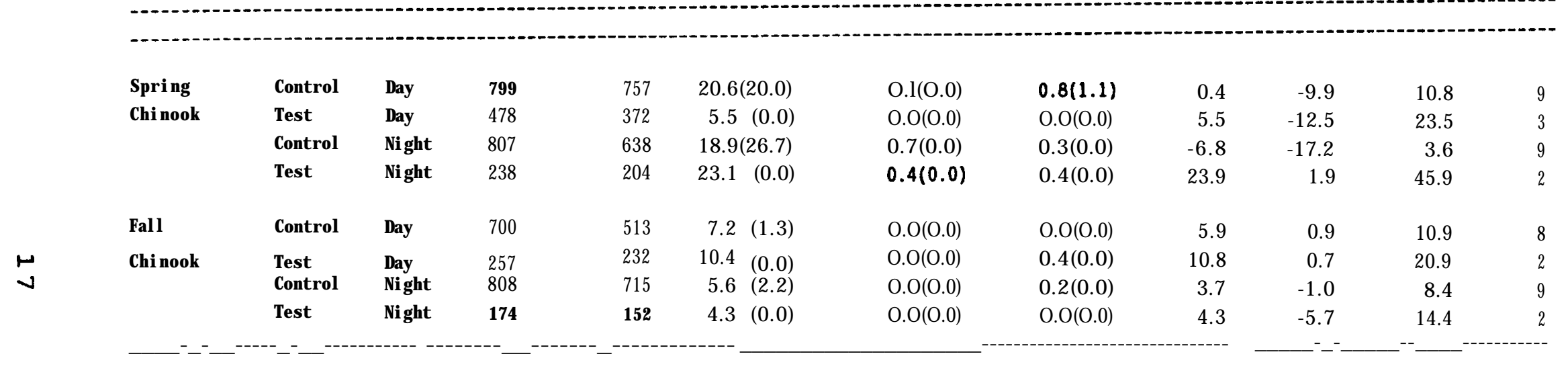


Tabl e 4. Esti mates of drum screen passage effi ci ency of $f$ al l chi nook sal mon fry at the $\mathrm{j}$ uveni l e $\mathrm{fi}$ sh bypass facility at Three Mle Falls Dam, Umatilla River, April 1991.

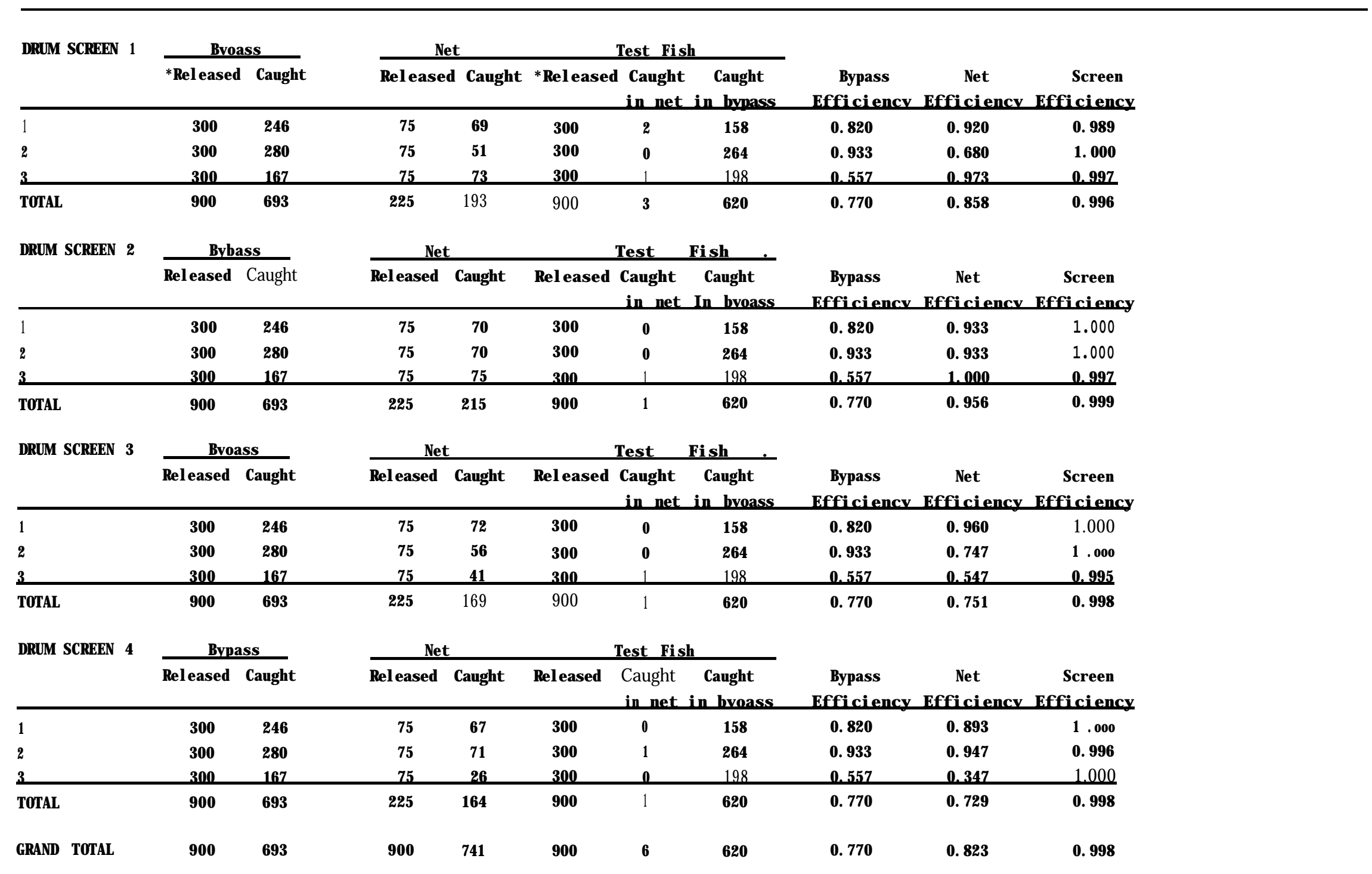

- A 300 fish group was rel eased upstream of the drum screens (test) and in the bypass channel (control) for each replicate test. 
Travel ing Screen Leakage and Fi sh I mpi ngenent: An attempt to capt ure I eakage fish on 9 April was thwarted as the net was torn by the force of the di scharge. The net was subsequentl y repai red and rei nstall ed on 15 May duri ng the fall chi nook outmigration. We capt ured 1 fal I chi nook subyearl ing ( $85 \mathrm{~mm}$ ) af ter 1 hour of sampling. Further sampl ing was abandoned as the net tore agai $n$ after rei nstal I ation.

During the drum screen I eakage test, we observed $108 \mathrm{fal}$ I chi nook sal non i mpi nged on the secondary travel ing screen (Table 5). These fry were test and control fish from the l eakage test. Sone of the fry were i mpinged in debris piles falling behind the screen. During the drumscreen l eakage test, the sl ui ce gate to the 21 - i nch river return drai $n$ pi pe was fully open.

We observed some i mpi ngenent on the travel ing screen of fry rel eased i $n$ the bypass channel when we operated the pumpback' pumps and when we opened the river return drai $n$ pi pe. During pumpback pump operation, some fry vere observed to "fi ght" the current pul I through the screen and becone temporarily i mpi nged before falling of the screen fromthe force of the spray water. When the ri ver return drai $n$ pi pe was open, turbul ent condi ti ons exi sted. These condi ti ons were unf avorable for fry when the pi pe was opened nore than 12-i nches, but uere i mproved when the pi pe was opened onl y g-i nches.

As fal I chi nook sal mon subyearlings migrated through the screening faci lity i n My, we observed occasi onal i mpingenent on the screen, di scovered fi sh in debris pi les behi nd the screen, and capt ured fi sh in a bucket pl aced adj acent to the screen (Table 5). During the fl ood i n I ate My, the sl ui ce gate was fully opened to clear silt in the pump enbaynent area. We di scovered numerous organi sns, i ncl udi ng fal I chi nook sal non subyearl i ngs, in the debri s pi l es behi nd the secondary screen. I mpi ngenent uas not observed duri ng a ful I bypass mode when al I bypass fl ow ( 25 cf s) was routed di rectly back to the ri ver wi th no travel ing screen, pump, or sl ui ci ng operation.

Travel Ti ne

Screen Facility: Fi sh travel ti mes past the drum screens vari ed by speci es and ti ne of day. Spring chi nook sal non travel ti mes showed I ittle difference bet ween day and ni ght tests wi th approxi matel y 3 hours requi red to capt ure $50 \%$ of the test $\mathrm{fi}$ sh and 58- 67 hours to catch $95 \%$ of test $\mathrm{fish}$ ( Fi gure 6). Fal I chi nook sal mon travel ed past the screens nore qui ckly at ni ght with $50 \%$ of the fi sh caught in 1 hour compared to 5.5 hours for dayti me tests. Summer steel head noved consi derably more sl ow y than spring or $f$ al I chi nook sal non, requi ri ng 10.5 hours and 162.0 hours to capt ure $50 \%$ and $95 \%$ of the test fi sh, respecti vel $y$. $\quad \mathrm{Nb}$ ni ghtti ne tests uere conducted with sumer steel head.

Lower Bypass: In the 5-cfs test, $25 \%$ of spring chi nook sal mon and $27 \%$ of $f$ al I chi nook sal mon noved through the outfal I system at the end of the fi rst hour. Summer steel head noved much more sl ow y through the outfal I bypass than chi nook sal non wi th $2 \%$ capt ured i $n$ the fi rst hour (Fi gure 7 ). Fl ushing the system with 25 cfs in the peri od 2- 4 hours after testing i ncreased the total percentage of spring chi nook sal non capt ured to $56 \%$ Fl ushing the system with 25 cfs after the first hour i ncreased capt ure rates 
Tabl e 5. Coservati ons of travel ing screen i mpi ngement of $f$ al l chi nook sal mon fry at the juveni I e fish bypass facility, Three MIe Fal Is Dam Unatilla Ri ver, 1991.

\begin{tabular}{|c|c|c|c|c|c|c|}
\hline$\overline{\text { Date }}$ & Ti ne & $\begin{array}{c}\text { Number of } \\
\text { subyearl i ngs }\end{array}$ & $\begin{array}{c}\text { Number of } \\
\text { fry }\end{array}$ & $\begin{array}{l}\text { Headuor ks } \\
\text { el evati on }\end{array}$ & $\begin{array}{c}\text { SI ui ce } \\
\text { Gate }\end{array}$ & Pumps \\
\hline 7 Apr 91 & 2205 & 0 & 20 & 404.0 & open & of $f$ \\
\hline 9 Apr 91 & 0900 & 0 & 87 & 404.1 & open & of $f$ \\
\hline 24 Apr 91 & 1015 & 0 & 1 & 403.9 & cl osed & on \\
\hline 8 May 91 & 0430 & 1 & 0 & 404.0 & cl osed & on \\
\hline 9 May 91 & 1820 & 1 & 0 & 404.4 & cl osed & on \\
\hline 10 May 91 & 0700 & 2 & 0 & 404.4 & cl osed & on \\
\hline 11 May 91 & 0630 & 2 & 0 & 401.0 & cl osed & on \\
\hline 12 May 91 & 0730 & 1 & 0 & $\mathbf{N D}$ & cl osed & on \\
\hline 13 May 91 & 0640 & 2 & 0 & $\mathbf{N D}$ & cl osed & on \\
\hline
\end{tabular}




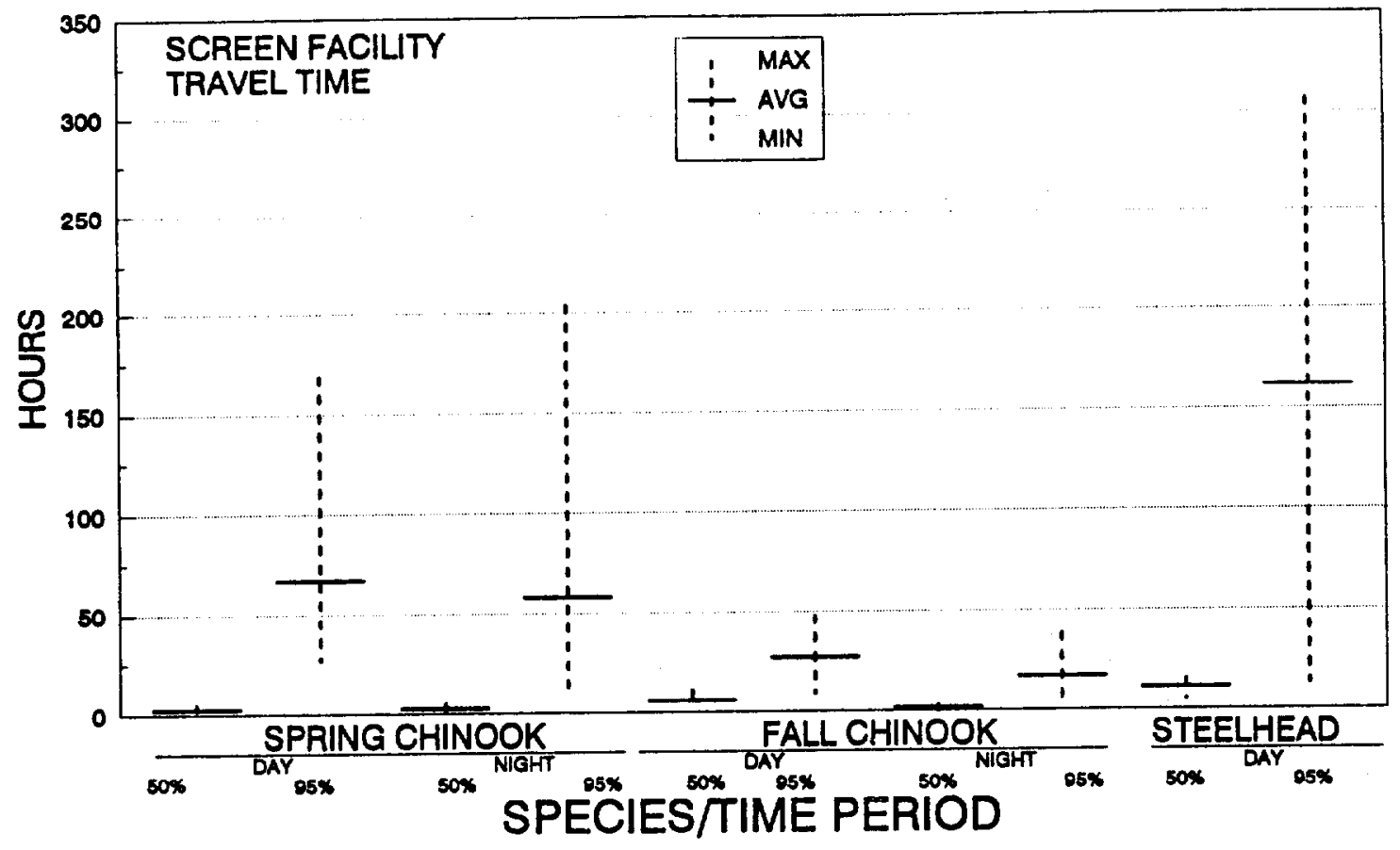

Figure 6. Mean number of hours required to capture $50 \%$ and $95 \%$ of fish released in the screen injury test at Three Mile Falls Dam, Umatilla River, 1991.

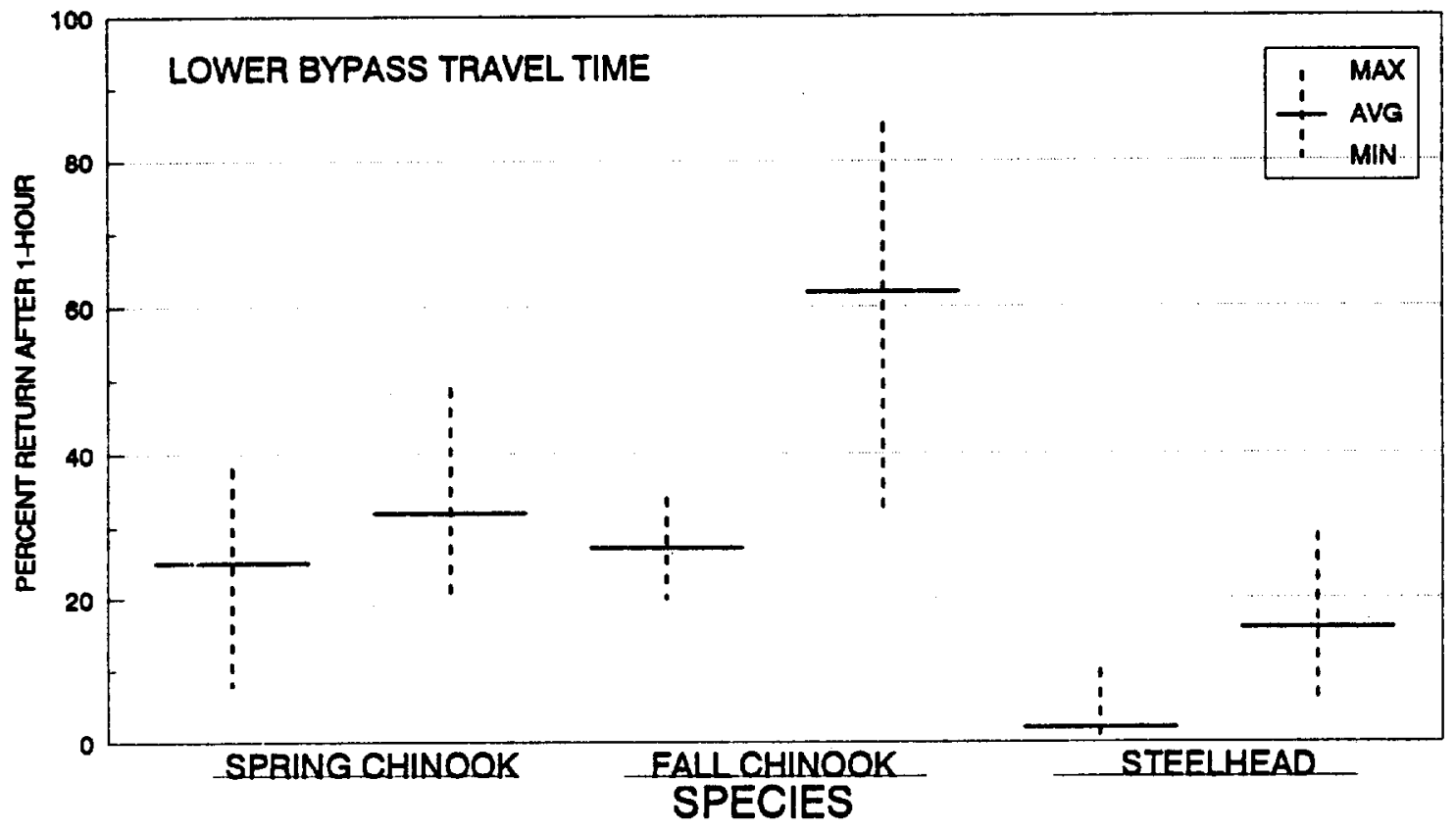

Figure 7. Percent of released fish recaptured at the end of a 1-hour sampling period during the outfall injury test at Three Mile Falls Dam, Umatilla River, 1991. 
for three groups of summer steel head by $41 \%$ An unknown number of $\mathrm{fish}$ ret urned to the river when the net pen was not in pl ace.

When $\mathrm{fl}$ ous i $\mathrm{n}$ the bypass were $25 \mathrm{cfs}$, mean capt ure rates were $62 \%$ and $16 \%$ for fall chi nook sal mon and sumer steel head, respecti vel y. Mean capt ure rate of spring chi nook sal mon after one hour of testing at a bypass fl ow of 25 cf s was $32 \%$

Passage

Fi sh Bypass Facility: We observed a di stinct pattern of di urnal passage of hatchery and wild j uvenile sal moni ds through the facility at Three MIe Fal I s Dam from upstream I ocati ons i $n$ the Unati I I a Ri ver (Fi gure 8). I n nost cases, movenent through the facility was greatest from sunri se through sunset. The hi ghest hourl y number of j uveni l e sal noni ds count ed was 1, 800 on 24 Apri I and approxi matel y 2,000 on 8 My 1991. Total ri ver run passage through the fi sh bypass facility from 5 Aprí to 10 April and from 23 April to 9 May 1991 was 41, $318 \mathrm{fi}$ sh. Ri ver fl ous during thi s peri od ranged from 400-1000 cf s. I ncl uded i $n$ our sample of ri ver run $f i$ sh on 2 May was a sockeye sal non neasuri ing $164 \mathrm{~mm}$ i $n$ I ength.

1990 Ladder Passage: J uveni I e fi sh counts peaked through the east bank fi sh I adder from 10 to 13 days after Unatill a Ri ver fl ous reached thei $r$ hi ghest poi nt ( Fi gure 9). Duri ng thi s ti me, approxi matel y 30,000 j uveni l e sal moni ds were observed movi ng past the vi ewi ng wi ndow The hi ghest dai ly count was 3,787 fi sh in earl y April and the I owest count was 89 on 4 May. Other di sti nct peaks occurred i n mid-Myy, I ate May, and earl y J une (end of observati on peri od). Fi sh I adder fl ow data during the observati on peri od was not avai I abl e.

Acti vi ti es at Maxuel I, Westl and, and Col d Spri ngs Di versi on Dans

During testing of the Maxuel I i ncl i ne pl ane bypass trap, we recovered al I 75 subyearli ng chi nook sal mon from rel eases made i $n$ the bypass channel. Onl y 7 of the $25 \mathrm{fi}$ sh rel eased i $\mathrm{n}$ front of the $\mathrm{middl}$ e drum screen were recapt ured. Most of the fi sh collected were in good condition, with onl y 7 showing si gns of parti al scal e I oss.

Our tests of the modi fi ed fyke net used at the West I and Dam j uveni I e hol di ng pond resul ted i $n$ recapt ure rates of $97 \%$ and $94 \%$ for the $f i$ rst and second rel ease groups, respecti vel y. Al fi sh in the second group were in good condition. Ei ghty-t wo percent of the fish in the first rel ease group were in good condition, with $6 \mathrm{fi}$ sh showing parti al scal e loss.

No trap testing was conducted at Cold Springs Dam The desi gn of the i ncl i ned $\mathrm{pl}$ ane bypass trap is described i $\mathrm{n}$ the methods section. 

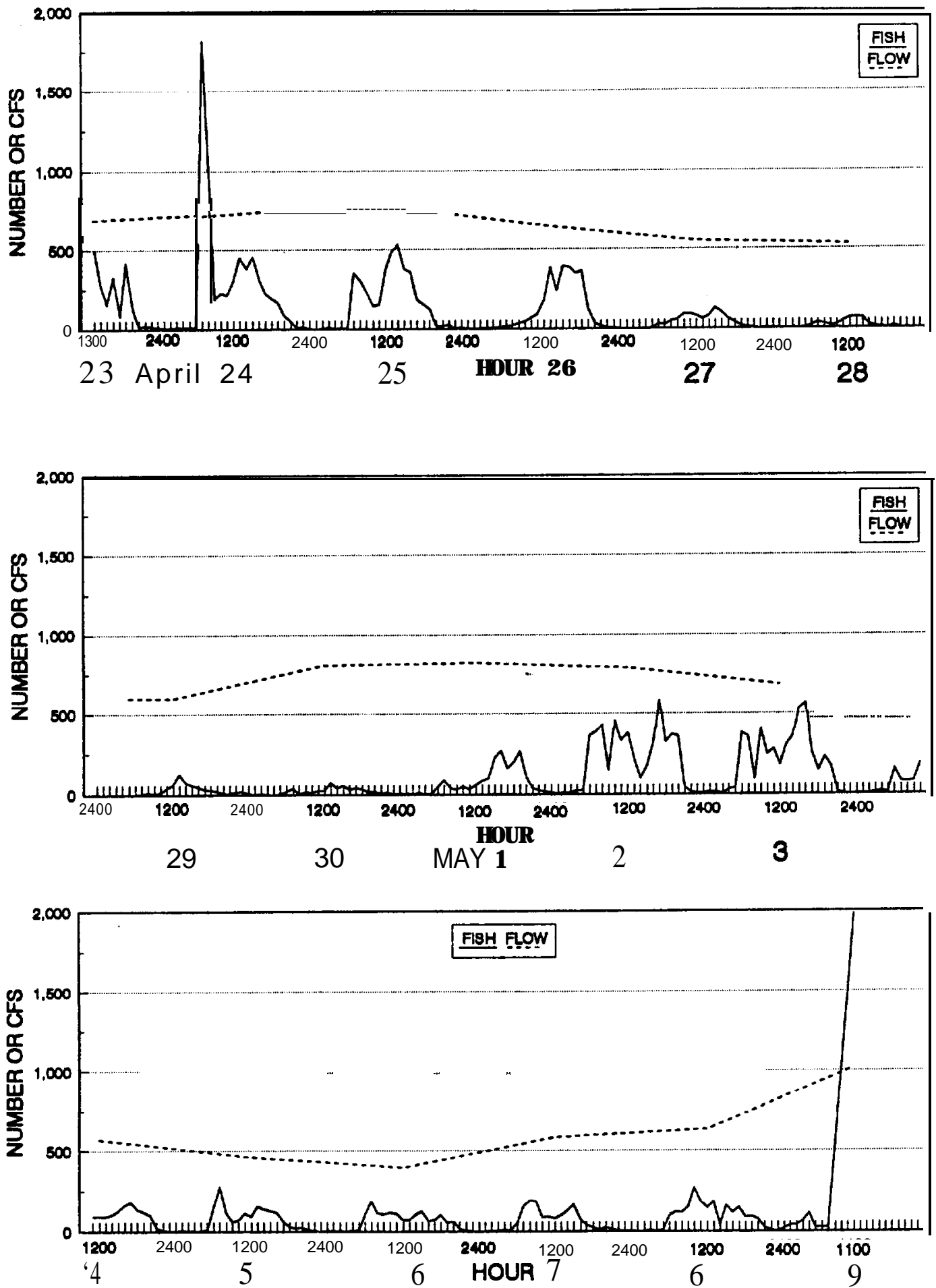

Fi gure 8. Number of river-run $\mathrm{j}$ uveni l e sal noni ds passing through the fi sh bypass facility at Three Mle Falls Dam and Unatilla Ri ver fl ous (cfs) near Unati Ila, OR, 23 April - 9 May 1991. 


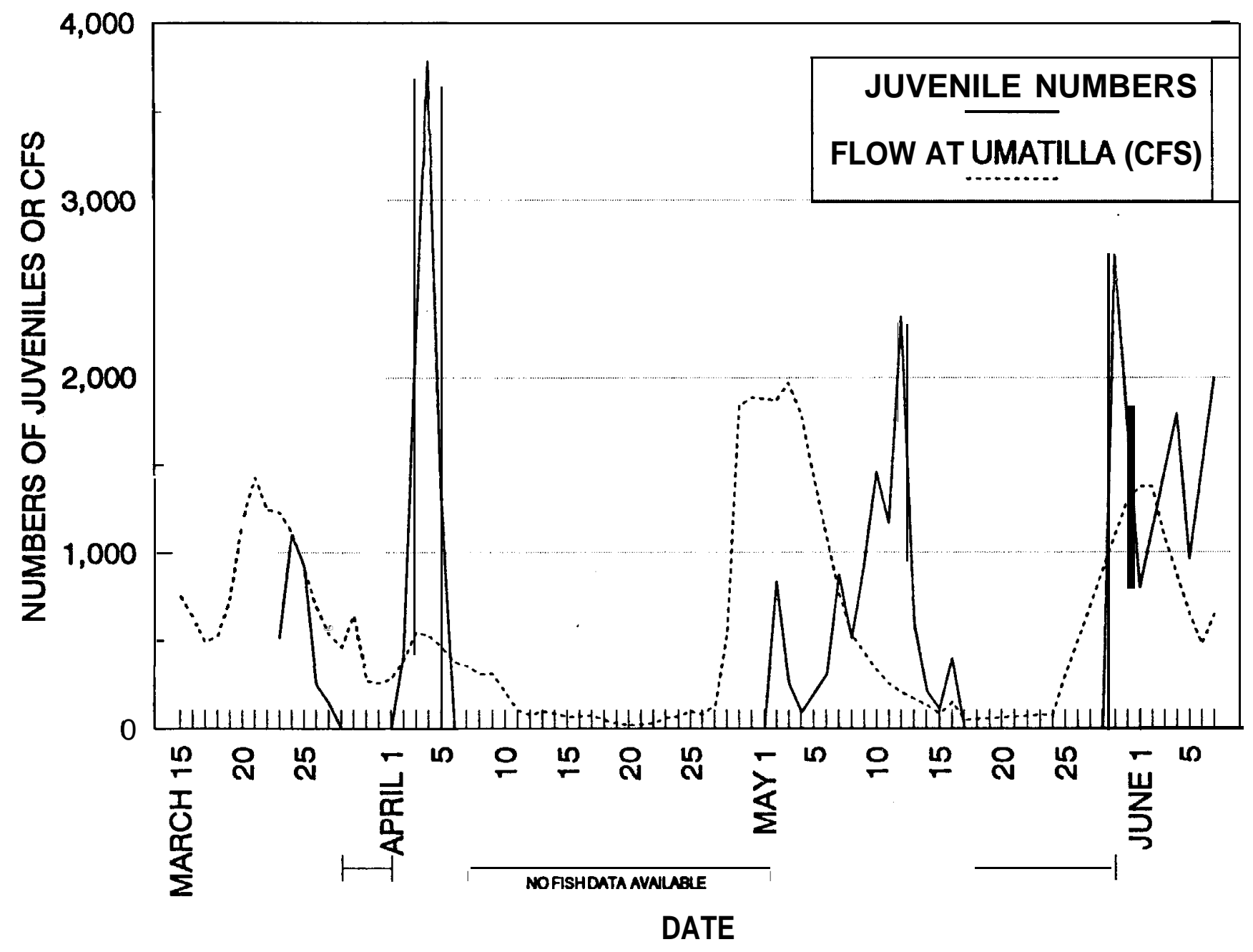

Fi gure 9. Vi deo tape counts of ri ver-run $\mathrm{j}$ uveni $\mathrm{l}$ e sal moni ds at the eastbank fi sh I adder, Three M Ie Fal Is Dam and Unatilla Ri ver fl ous (cfs) near Unatilla, OR, 15 March - 7 June 1990. 


\section{DISCUSSION}

\section{Three MI e Fal Is Dam J uveni I e Fi sh Bypass Faci I ity Eval uati on}

I nj ury

Snal I sample si zes may have conf ounded some of our resul ts. Wh-observed that negati ve net i nj ury rates were obtai ned i $n$ the screen i nj ury, bypass out $f$ al $I$ and headgate i nj ury tests, i ndi cating the condi $t i$ on of post-test $f i$ sh was better than pre-test $f i$ sh. Besi des the effects of smal l numbers of $f i s h$ used to determi ne pre-test condi ti on, these negati ve val ues were al so a resul $t$ of i nherent variabi lity in the descal ing eval uation.

The resul ts of the headgate i nj ury test were al so affected by smal I sample sizes and uncertai nti es about the condition of pre-test fish. Si nce f ew fi sh were avai I abl e, no subsampl es were eval uated for pre-test condi ti on and the assumpti on that thei $r$ conditi on was good may not have been val $i d$. Mre thorough testing wi I be attempted in 1992.

Based on our tests at Three M I e Fal Is Dam and a revi ew of ot her st udi es eval uating anadronous fi sh passage facilities in Northwestern ri vers, it is unl i kel y that any si gnificant i nj ury of fish i $n$ the Unatilla River can be attributed to the WEI D Canal fish bypass facility. Most of the high i nj ury rates that occurred in our tests were part of the sampl ing procedure and were not caused by the facility. The I ow fish i nj ury rates encountered during testing of fish passage through the fish bypass facility, past the screens, and through the outfal I pi pe at Three MIe Fal Is Dam uere si milar to results i n the Yaki ma Ri ver, Washi ngt on. Eval uati on at Yaki na Ri ver screeni ng facilities to determi ne passage inj ury to sal moni ds showed inj ury rates of I ess than 5\% (Hosey \& Associ ates 1990). Si milar tests at ot her facilities on the Yaki ma Ri ver al so showed I ow i nj ury rates, general I y I ess than $2 \%$ ( Nei tzel et al. 1985, 1986, 1988, 1990a, 1990b).

\section{Leakage}

The screeni ng effici ency of the rotary screens at Three MIe Fal Is Dans was hi gh and si milar to the performance of screens at Yaki ma River facilities ( Nei tzel et al., 1988, 1990a, 1990b). The onl y poor passage effi ci ency reported during that study was at the Westsi de Ditch (Neitzel et al. 1990b). In one test, $25 \%$ of ri ver run chi nook sal non fry passed through the screens, but the poor screen efficiency was bel $i$ eved to be caused by smal I fish size or behavi oral di fferences. General Iy, nost eval uati ons of rotary screens have shown screeni ng ef $\mathrm{fici}$ enci es greater than $99 \%$ and summary reports have suggested that angl ed screens are "hi ghl y effecti ve" (Taft 1986) in preventing fi sh I eakage. Cont i nued mai nt enance of the facilities at Three MIe Fal Is Dam emphasi zi ng upkeep of the seal s and adherence to operating criteri a wi I ensure that $j$ uveni $l$ e fish are effici ently screened from the canal and ret urned to the Unatilla River. 
Travel Ti me

Si nce canal fl ows were not al tered during the screen inj ury test and we di $d$ not have detai led i nf or mati on on the movenent of ri ver-run fi sh, we coul d not di rectly determine if the upper bypass had the potential to del ay fish migration. However, in most cases, at l east $50 \%$ of the test fi sh noved through the WEID screeni ng facility in I ess than 11 hours and it di not appear that fi sh movenent was del ayed. Our results were si milar to the range of sal mon and steel head travel ti nes reported i n Yaki ma Ri ver screen faci I i ty eval uati ons (Hosey and Associ ates 1990; Nei tzel et al. 1985, 1986, 1988, 1990a, 1990b). In both ri ver systens, chi nook sal mon were found to move through the bypass faciliti es much nore qui ckl y than sumer st eel head.

Si milarly, we found that sal mon novenent was af fected by ti me of day with fish usual I y novi ng more rapi dl y at ni ght.

Our anal ysi s of travel ti mes through the I ower bypass duri ng dayl i ght hours i ndi cated that fall chi-nook sal mon and sumer steel head noved nore sl ow y through the bypass outfal I pi pe at I ow fl ous than at hi gh fl ows. Much of the sl ower novement in our tests was caused by fish hol di ng in a pocket of water at the end of the bypass pi pe to the outfal I structure. We observed groups of $\mathbf{f} i$ sh hol di ng i $n$ the out $f$ al I struct ure on several occasi ons, and thi s corroborated observati ons made i n 1990 (Knapp and Wtrd 1990). Hosey and Associ at es (1990) found that for sal noni ds rel eased in the early eveni ng, novenent through a Yaki na Ri ver outfal I bypass pi pe was rapid. However, the fI ow vol une i $n$ the VEI D Canal is general I y smal I er than Yaki ma Ri ver canal s and i n conbi nati on wi th ti me of day variables, nay parti al l y account for the di ff erences observed i $\mathbf{n}$ our tests. A though $\mathbf{N}$ et zel et al . (1985, 1986, 1988, 1990a, 1990b) di d not di rectly test transit ti mes through outfal I pi pes, they reported sl ower fish movenent during l ow fl ous at several si tes on the Yaki ma Ri ver and suggested that fi sh could be fl ushed through some facilities. We were able to flush fi sh through the bypass system when fl ow was 5 cf s by i ncreasing fl ow to 25 cfs for a short period of ti me. Changes in the outfal I desi gn should be consi dered to reduce thi s problem and pass fi sh nore rapi dly at I ow fl ous. The operating gui del i nes at Three M I e Fal I s Dam ( USBR 1989) that requi re 25- cf $s$ bypass fl ow when the drum screens are i nst al I ed and operating appear to be val i dated, and show the i mportance of provi di ng hi gher bypass fi ous during critical migration periods to quickly ret urn fish to the ri ver.

It is I i kel y that a wi de range of fish migration behavi ors wi I be observed during this study and the causes for different patterns wil be difficult to ascertai $n$. Several variables are i nvolved that differ from river to river and could affect passage ti mes, i ncl udi ng si ze of fi sh, snol ti ng st age, I ocal fI ow condi ti ons, stream hi st ory, and i ndi vi dual characteri sti cs of the facility. Future testing my hel $p$ to describe fish migration through the fish bypass facility and determine if it is any different from mgration patterns in the river.

Passage

It appears that most $\mathbf{j}$ uveni le sal noni ds move through the Unati I a Ri ver and i nto the Col unbi a Ri ver duri ng short wi ndows of opportunity. We st opped monitoring fi sh passage in early My 1991 and failed to separate fi sh speci es 
or strai n; therefore, we could not determi ne how speci es-specific acti vi ty affected the counts. Fi sh counts i $n$ the WEI $D$ fi sh bypass facility i ncreased in magni tude at daybreak. Duri ng our moni toring peri od, most schedul ed hat chery rel eases in the Unati I la Basi $n$ were coho and chi nook sal mon (CTU R 1991) and we assumed that these species comprised the bul $k$ of dayl ight migrati on activity. Thi s assumpti on was corroborated by data from Nei tzel et al. (1987) where coho and chi nook sal mon in the Yaki ma Ri ver mi grated at daybreak whi I e steel head migrat ory acti vi ty i ncreased at sundown.

A though a $\mathrm{clear}$ rel ati onshi $p$ bet ween $\mathrm{fi} h$ passage and $\mathrm{river} f \mathrm{l}$ ow was not establ i shed, it is probable that fl ow was i mportant. Mbvenent on 24 Apri I may have been triggered by a peak fl ow of 1,020 cfs on 15 April. The count on 8 Myy coi nci ded wi th fl ous greater than 1,000 cfs, but was not preceded by hi gh fl ow A conbi nati on of factors i ncl udi ng ri ver fl ow fi sh si ze and condi ti on, st ocking I ocations and dates, and year to year seasonal variability will determine the exact ti ming of $f i s h$ passage. Si nce a pri mary goal for the basi $n$ is to reestabl i sh nat ural l y produci ng sal moni d popul ati ons ( NPPC 1989), it i s essential to accuratel y document the periods when peak migration occurs to ensure opti mal operation of the VEI Canal fish bypass facility for effici ent fish passage.

\section{Tests}

Some of the tests compl eted i $n 1991$ wi l be repeated in 1992 to i mprove on i nconcl usi ve or uncompl eted tests. Several aspects of the eval uati on can be i mproved to i ncrease the conf i dence in our test results. An accurate anal ysis of fish inj ury caused by the facility depends on starting the tests with fish in good condition. In several cases, a significant portion of fish used i n 1991 were i n poor condi ti on pri or to testi ng. In addi ti on, an attempt will be made to ensure more uni form si ze di stributi on wi thi $n$ each test speci es group. It is probabl e that the wi de si ze range of sumer steel head used added to the variability of the test results.

We wi I i mpl enent an i mproved stati stical desi gn in 1992 to provi de more bal ance bet ween treat ment and control tests. Occasi onal I y i n 1991, we pool ed control s thereby reducing the sample sizes for testing. We will al so attempt to subsample a larger number of fi sh to determi ne the pre-test condi tion. The appearance of negati ve numbers i $n$ the comput at $i$ on of the net-i nj ury rate nay have been the resul $t$ of subsampling a snal l number of $f i s h$. Our plans for 1992 at Three M I e Fal Is Dam are descri bed i n our statenent of work (Appendi x A). Wbrk at Maxuel I Dam will be di sconti nued because of pl ans by the Bureau of Recl anation to cease operation of this facility in the near fut ure.

\section{Operati onal and Struct ural Problens at Three MI e Fal I s Dam}

Sampl i ng Equi pment

We experi enced great difficulty in our efforts to renove and depl oy the bypass channel sampl ing equi pment ( $\mathrm{i}$ ncl i ned screen and separat or sampl e box) duri na our eval uation. The eaui onent uas cumbersome to maneuver and di fficul $t$ to al i gn properly. We al so had difficulty changing froma ful I bypass mode to a sampling mode when $f i s h$ vere in the bypass channel. Unl ess fi sh were 
renoved from the bypass channel bet ween the wei $r$ gate and orifice pl ate bef ore the i ncl i ned screen was depl oyed, they woul d becone trapped under neat $h$ the i ncl i ned screen and be ul ti matel y fI ushed through the auxi I i ary i nf I ow system Occasi onal ly, thi s occurred and created bl ockages in the auxili ary i nf I ow I i nes. To effectivel y drai $n$ and remove fi sh from thi s area, a stopl og was i nstal I ed downst ream of the travel ing screen and fi sh were netted out.

There is no easy and ef $\mathrm{f}$ ci ent means to depl oy the i ncl i ned screen, nor are operating instructi ons i ncl uded in the desi gner's operating criteri a for the facility (USBR 1989). We i nserted an eye bol t into the top edge of the screen to permi I ifting and maneuvering with the crane. The i ncli ned screen needed to be in the correct l ocation and proper position when I over ed to attach it to the support frame. The si de and bottom rubber seal s tended to curl under the screen during depl oyment and extra ef fort was requi red to keep them properly al i gned. Fut ure operat ors of this equi pnent will need to be aware of the problens to ensure efficient and effective use.

J uveni l e sal noni ds conti nued to escape i nto the bypass downuel I inst ead of bei ng di verted i nto the sampl ing-trapping area during the sampl ing node. A though I oss of fish was reduced with the i nstal I ati on of a 2-i nch neoprene barrier at the downst reamend of the separat or in 1990 (Knapp and Whrd .1990), some fish were still l ost when fi sh entered the separat or too rapi dl y or at a perpendi cul ar ori entati on to the separator bars. Conti nued I osses may requi re that the separator be redesi gned or that another nodified barrier devi ce be installed. These I osses pri narily occurred when water fl ous and canal water I evel s were normal or somewhat hi gh. At I ow ri ver fl ous and a headuorks water el evati on bel ow 404. 1, water and fi sh trickle ont o the separat or and fi sh I oss at the end is not a problem The concern in this scenario is the need to prevent water I oss through the separat or top perforated pl ate, a recommendati on that was made previ ousl y (Knapp and Vhrd 1990).

During sampl ing, we observed that fi sh became trapped behi nd a perforated pl ate on the back si de of the sample box. d oser i nspection reveal ed that a gap exi sted al ong the edge of the transfer chute that I ed from the separat or sample box to the transfer fl une. Thi s gap probabl y resul ted from bypass i nf I ow water pressure di storting the separat or assembl y and I eavi ng a gap on the upstream edge. Fi sh di verted i nto the transfer fl une apparent l y swam back up the current, I ocated the si de gap, and suam behi nd the perfor at ed pl ate, onl y to become trapped and die. Thi s problem was nost pronounced duri ng the $f$ al I chi nook out migration because of the smal I average size of the chi nook sal non subyearli ngs.

We document ed several ot her fi sh-rel at ed struct ural probl ens that wi I I requi re annual i nspecti on and mai nt enance to correct or prevent, i ncl udi ng an unsecured rubber seal at the bott om of the i ncl i ned screen. The pri mary concern is I eakage or escape of $f i s h$, reduci ng di versi on eff ect $i$ veness. The fact that one fal I chi nook sal non subyearl i ng ( $86 \mathrm{~mm}$ i $\mathrm{n}$ I engt h) was capt ured i $n$ the fyke net at the terminus of the river return drai $n$ pi pe i ndi cates possi ble travel ing screen l eakage. Apparently, operati onal and structural probl ens pose the greatest threat to smal I fal I chi nook sal non subyearli ngs. 
Travel i ng Screen

Fi sh i mpi ngenent on the secondary screen (travel ing screen) duri ng the sampl i ng mode was the pri mary bi ol ogi cal problem observed at the facil ity. During the sampling node, 20 cfs is taken through the travel ing screen and pumped into the canal or returned to the river through the 21-i nch di anet er river return pi peline. The remi ni ng 5 cfs passes through a bypass orifice $\mathrm{pl}$ ate at the downstream end of the secondary screen. When the sl ui ce gate to the ri ver return pi pel i ne was opened rather than operating the pumps, we observed i ncreased i mpi ngement rates of fry.

Contri buting factors to thi s i mpi ngenent probl em nay have i ncl uded the presence of a hydraulical I y i neffici ent transition of 25 cfs fl ow from the bypass entrance to 5 cfs fl ow through the orifice plate. Because of an abrupt noment um I oss upstream of the ori fi ce pl ate, an unstabl e fl ow condi ti on at the screen face was created that resul ted in surging and i nst antaneous hi gh vel ocity hot spots at the screen face. Depending on the degree of sl ui ce gate openi ng, the fl ow through the travel ing screen when excess bypass fl ow is bei ng ret urned to the river can exceed 30 cfs (I etter dated 10 October 1991 from WS. Rai ney, Nati onal Mari ne Fi sheri es Servi ce, to J. Marcotte, Bonnevi I l e Power Admi ni strati on).

As $\mathrm{fi}$ sh becane i mpi nged on the screen, they woul d "roll-over" to the back si de of the screen because of insufficient spray water i $n$ the i mpi ngenent l ocation. Our observati ons were that i mpi ngement occurred enti rel y in the northeast corner of the rotating screen, an obvi ous "hot spot" area that did not recei ve suffi ci ent fl ushing wi th spray water. Apparently, frequent pl ugging of the terminal spray nozzle on the spray water bar occurred because of ri ver debris.

There exi sts a need to renedy the i mpi ngenent probl em with struct ural or operati onal modificati ons. A recommendat i on has been made to operate onl y one pump to reduce the bypass entrance fl ow from 25 cfs to $15 \mathrm{cfs}$, and reduce fl ow through the secondary screen by $50 \%$ Thi s approach woul d I i kel y reduce surging near the secondary screen and al l ow nore effici ent hydraul ic conditions for fish passing through the bypass orifice plate. This could be i $\mathrm{mpl}$ enent ed if $15 \mathrm{cfs}$ provi des enough fl ow to effici ently ret urn fi sh to the river. In addition, it was recommended that use of the sl ui ce gate shoul d be I i mited to short peri ods during dayl i ght hours, when juvenile passage rates are presumed to be at the l owest I evel s, and throttled back as i mpi ngenent is observed (I etter dated 10 october 1991 from W S. Rai ney, Nati onal Mari ne Fi sheri es Servi ce, to Jay Marcotte, Bonnevi I le Power Admi ni stration). In I i ght of our fi ndi ngs on diel passage of river run $f i$ sh i $n$ which passage rates uere hi shest during dayl i ght hours, a ni ghtti me operati on of the sl ui ce gate may be preferable. Thi s nould be particul arly i mportant during fut ure high water events, when heavy ri ver si It I oads and sedi ment ati on probl ens at the facility nould requi re i ntensi ve sl ui cing efforts.

\section{Operating Criteri a}

Fl uct uati ons i $\mathbf{n}$ headworks water I evel above or bel ow the normal operati ng criteria of 404.1 are a concern because they af fect bypass operati ons. At I evel s greater than 404. 1, fi sh and debri s may rol I-over at the drumscreens. 
These si tuati ons my occur when ri ver fl ow rises suddenl y as during the fl ood in I ate My 1991. Mre than $\mathbf{8 0 \%}$ of the drum screens were submerged duri ng thi s hi gh fl ow event. At l evel s l ess than 404. 1 (403.9) sampl ing efforts are hampered because mi ni mat er fl ous across the top of the i ncl i ned screen. Thi s probl em was reported previ ousl y (Knapp and Ward 1990) and nay be a concern when trappi ng and haul ing juveni l e sal noni ds duri ng I ow ri ver fl ow

\section{Act i vi ti es at Maxwel I, Wesst l and, and Col d Spri ngs} Di versi on Dans

We encountered very few problens during testing of traps at Maxuel I and Westl and dans. At Maxuel I Dam the pri mary operati onal probl em encountered was the formation of a backwash eddy in the front corners of the trap that stranded fish entering this area. It was necessary to push these fish into the mai $n$ water fl ow for recapt ure in the $I i$ ve box. We subsequent l y nodi fi ed the trap by ri veting al umi num pl ates di agonal $\mathrm{y}$ across the front corners to prevent stranding of $\mathrm{fish}$. We al so recovered less than $30 \%$ of subyearling chi nook sal mon rel eased i $n$ front of the middl e drum screen. These $f i$ sh were observed school ing in the screen forebay. At Wistl and Dam the net appeared to work wel I and the onl y modificati on made was the i ncl usi on of addi ti onal fl oatati on materi al on the I i ve box. Our pl ans for 1992 at Westl and Dam are descri bed i n our 1992 statement of uork (Appendi x A). 


\section{RECOMMENDATIONS}

Based on our efforts during the eval uation, we recomend the fol I owing i mprovenents to ensure safe and effective $f i$ sh passage through the $j$ uvenil $e$ fi sh bypass facility at the VEI Canal.

1. The headgates and checkgates to the VEI D Canal shoul d be aut onated to ensure proper water I evel el evati ons in the forebay and headuorks area at al I ti nes. A normal operating water surface el evation of $404.1 \mathrm{ft}$ at the drum screens should be mai ntai ned whenever possi ble to ensure effecti ve operation of the facility components.

2. A I equi pment seal s shoul d be . annual ly i nspected and regul arly repl aced to prevent fi sh I oss. Thi s would i ncl ude the secondary travel ing screen, the pri mary drum screens, and bypass channel sampl i ng equi pment. Apparent l y, structural defici enci es pose the greatest threat to smal l fish (fry and subyearl i ngs).

3. The operating criteria for the I eft bank fish facilities at Three Mle Fal Is Dam shoul d be anended to i ncl ude speci fic gui del i nes for operat ing the sl ui ce gate to the 21-i nch ri ver return drai $n$ pi pe, and for depl oyi ng sampl ing equi pment. We recommend that the sl ui ce gate not be operat ed during dayl i ght hours when fish passage is most preval ent. Operators need to be made aware that thei $r$ actions ma cause i nj ury to and l oss of fish.

4. A mechani sm to control the anount of water el i mated through the fi sh separat or perforated $\mathrm{pl}$ ate is needed duri ng I ow fl ow peri ods, parti cul arl y when trappi ng or sampl ing is occurring unattended. Fi sh can be stranded on the perforated $p l$ ate, and in the sample box and transfer flume if Iittle water reaches these areas.

5. In concurrence with the Nati onal Mari ne Fi sheri es Servi ce, we recommend that onl y one pump be operated during nodes other than a ful I bypass mode to reduce the bypass entrance fl ow from 25 cfs to 15 cfs. This noul d reduce by hal $f$ the fl ow through the secondary screen and decrease surging in the separati on chanber.

6. The operating criteria for the VEID Canal, as anended, should be fol I owed in the effort to protect fish that nove through the system Operating gui del i nes and criteri a should be made readi ly avai I abl e for al I users of the facility. Staff gauges should be installed at al critical locations to determine compl $i$ ance with the operating criteria.

7. A neans to prevent fish from l eavi ng the transfer chute and entering behi nd the back perforated $\mathrm{pl}$ ate in the sampl e box shoul d be i nvesti gat ed. Removal of the nonf uncti onal perf pl ate woul d el i mate this pot ent $i$ al trapping si te. 


\section{TERATURE CI TED}

Boyce, R. R. 1986. A comprehensi ve pl an for rehabi I i tati on of anadroncus $f$ ish stocks i $n$ the Unatilla $R i$ ver basi $n$. Fi nal report to Bonnevi I l e Pouer Admi ni strati on by Oregon Department of Fi sh and Vild il fe. Contract Nb. DE-A179-84BP18008. Portl and, OR, USA

Conf ederated Tri bes of the Unati I I a I ndi an Reservati on and Oregon Department of Fi sh and Vil dl i fe. 1990. Unati I I a basi $n$ artifici al fi sh producti on pl an. October 1990 - Sept enber 1990. M ssi on, OR.

Fast, D. E. , J. D. Hubbl e, and B. D. Whtson. 1986. Yaki ma Ri ver spri ng chi nook enhancenent study. Prepared by the Di vi si on of Fi sheries, Yaki ma I ndi an Nati on, for the Bonnevi I le Power Admi ni stration, Portl and, Oregon.

Hosey \& Associ ates. 1988. Eval uati on of the ef fecti veness of $\mathbf{f i}$ sh protection facilities. Chandl er facility eval uation. Report by Hosey and Associ ates Engi neering Company for the U.S. Bur eau of Recl anati on.

Hosey \& Associ ates. 1989. Eval uati on of the ef fecti veness of fi sh protecti on facilities. Roza facility eval uation. Report by Hosey \& Associ at es Engi neering Company and Fi sh Managenent Consul tants for the U. S. Bureau of Recl anation.

Hosey \& Associ at es. 1990. Eval uation of ef fecti veness of $\mathbf{f i}$ sh protection facilities. East on facility eval uation. Report by Hosey \& Associ at es Engi neeri ng Company and Fi sh Managenent Consul tants for the U.S. Bur eau of Recl anation.

Hosey \& Associ ates. 1990. Eval uati on of ef fecti veness of fi sh protecti on facilities. Eval uati on of Chandl er, Col umbi a, Roza and East on screeni ng facilities, compl eti on report. Report by Hosey \& Associ ates Engi neeri ng Company and Fi sh Managenent Consul tants for the U. S. Bur eau of Recl anation.

Knapp, S. M 1991. Pages 4 to 49 i n S. M Knapp, edi tor. Eval uati on of j uveni l e fish bypass and adul $t$ fish passage facilities at water di versi ons in the Unatilla Ri ver. Annual Progress Report to Bonnevi I l e Power Admi ni strati on, Portl and, Oregon.

Knapp, S. M, and D. L. Whrd. 1990. Pages 4 to 32 in A A N gro, edi tor. Eval uat $i$ on of $\mathbf{j}$ uveni $\mathbf{l} \mathbf{e} \mathbf{f} \mathbf{i}$ sh bypass and adul $\mathbf{t} \mathbf{f} \mathbf{i}$ sh passage facilities at Three Mle Fal Is Dam Unatilla Ri ver. Annual Progress Report to Bonnevi Il e Power Admi ni strati on, Portl and, Oregon.

Nei tzel, D. A, C. S. Abernethy, E. W Lusty, and L. A Prohamer. 1985. A fi sheri es eval uati on of the Sunnysi de Canal fi sh screeni ng facility, spring 1985. Prepared by the Pacific Northwest Laborat ory, Ri chl and, Wishi ngt on for the Di vi si on of Fi sh and V'I I l i f e, Bonnevi I I e Power Admi ni strati on, Port l and, Oregon. 
Nei tzel, D. A , C. S. Abernethy, and E. W Lusty. 1987. A fi sheri es eval uati on of the Ri chl and and Toppeni sh/Sat us Canal fi sh screening facilities, spring 1986 . Prepared by the Pacific Northuest Laboratory, Ri chl and, Wishi ngt on for the Di vi si on of Fi sh and V'I dl i fe, Bonnevi I l e Power Admi ni strati on, Portl and, Oregon.

Nei tzel, D. A , C. S. Abernet hy, E. W I usty, and S. J. Whmpl er. 1988. A fi sheri es eval uati on of the Ri chl and and Wato Canal fi sh screening facilities, spring 1987 . Prepared by the Pacific Nort hwest Laborat ory, Ri chl and, Whshi ngt on for the Di vi si on of Fi sh and $V^{*}$ I dl i fe, Bonnevi I l e Power Admi ni strati on, Portl and, Oregon.

Nei tzel, D. A , C. S. Abernethy, and E. W Lusty. 1990a. A fi sheri es eval uati on of the Toppeni sh Creek, Whato, and Sunnysi de $\mathbf{f i}$ sh screening facilities, spring 1988. Prepared by the Pacific Nort hwest Laborat ory, Ri chl and, Whshi ngton, for the Di vi si on of Fi sh and Vil dl i fe, Bonnevi I l e Power Admi ni strati on, Portl and, Oregon.

Nei tzel, D. A , C. S. Abernethy, and G A Mart enson. 1990b. A fi sheri es eval uati on of the Westsi de Ditch and Toun Canal fi sh screeni ng facilities, spring 1989. Prepared by the Pacific Northwest Laboratory, Ri chl and, Wishi ngt on, for the Di vi si on of Fi sh and W'I dl i fe, Bonnevi I I e Power Admi ni strati on, Portl and, Oregon.

Northuest Pouer PI anni ng Counci I. 1987. Col unbi a Basi n Fi sh and Vil dl i f e Program (as anended). Northwest Power PI anni ng Counci I . PortI and, OR, USA.

Nort huest Power PI anni ng Counci I. 1989. Unati I I a Hatchery Mast er PI an. Nort huest Power PI anni ng Counci I. Portl and, $\mathbf{O R}$, and Pendl et on, $\mathbf{O R}$, USA

SAS Institute I nc. 1990. SAS Language: Reference, Versi on 6, Fi rst Edi ti on Cary, NC: SAS I nsti tute I nc. , 1042 pp.

Taft, E. P. 1986. Assessment of downst ream mi grant fi sh protect i on technol ogi es for hydroel ectri c appl i cati on. Research Proj ect 2694-1, St one \& Webster Engi neeri ng Corporation, Bost on, MA

U. S. Bur eau of Recl anati on. 1989. Prel i mi nary desi gner' s operating criteria. Three MIe Fal Is Di versi on Dam l ef $t$ bank $f$ i sh facilities, Unatilla project, Oregon. Denver, CO. 


\author{
APPENDI X A \\ 1992 PI anned Acti vi ti es for the \\ Unati I l a Ri ver Passage St udy
}

\title{
Coal s and Obj ecti ves
}

Our st udy goal is to eval uate the passage of $\mathrm{j}$ uveni I e sal noni ds at di versi ons in the Unati I l a Ri ver and make recomendati ons to i mprove passage, if appl i cable. We will i nvesti gate effects faci lity operati on and struct ure have on j uveni l e fish and thei $r$ abi I ity to bypass di versi ons. Our ef forts from 1989 through $1990 \mathrm{i}$ ncl uded modi fi cat $i$ on and operat $i$ on of the $j$ uveni l e bypass system i $n$ the VEI D Canal at Three M I e Fal Is Dam to obtai $n$ prel i mi nary i nf or mati on on faci I ity effi ci ency and $\mathbf{j}$ uveni l e sal moni $d$ condi $t i$ on and passage. In 1991, we prepared for and conducted a ful I-scal e eval uati on of $j$ uveni l e passage at the WEID faci I ity, and desi gned and fabri cated sone fi sh capt ure facil i ti es for Mexuel I, Westl and, and Cold Spri ngs dans to enhance our abi l i ty to conduct fut ure eval uations of these facilities.

The three objectives for the 1991-1992 project period are to 1) determine if probl ens exi st with passage of summer steel head, and spring and $f$ al $I$ races of chi nook sal mon through the headgates and the bypass system in the VEI D Canal and through the east bank adul $t$ fi sh I adder at Three M I e Fal I s Dam 2) conduct a feasi bi I ity study at West I and Dam to ensure readi ness for a 1993 eval uati on, and 3) deternine if fl ow characteri stics at defi ned I ocations in the screeni ng facilities at Three MIe Fal Is and Vestl and dans neet desi gn specificati ons. Eval uati on efforts at Maxuel I Dam will be abandoned due to planned termi nation of canal and facility operation in the near future as a resul $t$ of Phase II compl et $i$ on of the Fl ow Enhancenent Proj ect.

Def i ni ti ons

Eval uati on efforts will be accompl i shed in the context of specific task parameters. For clarity in the purpose of this study, these parameters are defined as fol I ous:

Passage: the novenent of $\mathrm{fi}$ sh through the components of a fi shway or di versi on screeni ng facility, from thei $r$ entrances to thei $r$ ri ver ret urn outl ets. Passage wi II al so refer to "I eakage" of juveni l e fi sh through or over a screening structure.

Passage Success: the ability of fish to pass or navi gate through a fi shway or di versi on bypass system and be returned to the river wi hout i ncurri ng i nj ury or nortal i ty, or experi enci ng i mpedi ments to nat ural novenent or, for j uveni l e fi sh, I oss into the canal.

Di versi on Rate: the cumul at $i$ ve percent of rel eased $j$ uveni l e fi sh that enter a di versi on system 
Travel Time: average ti me for rel eased fi sh to travel froma rel ease poi nt to a recovery poi nt.

Injury: fi sh i ncurring body i nj uries or scal e I oss during passage froma rel ease poi nt to a recovery poi nt.

Mbrtality: fish not surviving passage froma rel ease poi nt to a recovery poi nt as a resul $t$ of i nj uries.

Document: to observe presence or absence.

Estimate: to determi ne percent of $\mathrm{fish}$ in a rel ease and recovery test.

Test Fi sh: fi sh used in a mark and recapt ure study.

Ri ver Run Fish: nontest $f i$ sh that are part of the adul $t$ fish migration or j uveni l e fish outmigration.

Eval uati on: the synthesi s of esti mates, observations, and determi nati ons to determine the synergi stic effects of a systemin the overal I context of passage success.

Specifical Iy, we wi I repeat several i nj ury and l eakage tests and take addi ti onal vel ocity measurements at Three Ml e Fal Is Dam because we were unabl e to satisfactorily compl ete these tests in 1990 and 1991. We will al so 1) document passage and esti mate i nj ury of $j$ uveni l e fi sh movi ng through the east bank I adder at Three MIe Fal Is Dam 2) take vel oci ty measurements at specific l ocations in the Westl and Canal screening facility, 3) operate the Westl and facility bypass and associ ated structures, and 4) desi gn and fabricate al I col lecti on traps to carry out an eval uati on at Westl and Dam i n 1993.

We wil esti mate inj ury and mortality of fish associ ated with the Three Mle Fal I s Dam passage faciliti es by rel easing groups of narked $f i$ sh at vari ous l ocati ons i $n$ the I adder and di versi on canal, recapt uri ng them at downst ream si tes, and i nspecting them for mortal ity, descal ing or ot her i nj ury. We will make corresponding rel eases in the recapt ure facilities to assess and compare i nj ury caused by the collection and handling process. We will esti mate travel ti me by determining the difference bet ween $t i$ me of rel ease and ti ne of recapt ure. We will esti mate di versi on rates by the proportion of fish entering a di versi on system fromthe total number of fi sh rel eased i $n$ front of the headgates. Wi wil esti mate fi sh I oss i nto the canal through the travel ing screen by rel easi ng groups of $\mathbf{f}$ ish upstream from the screens and recapt uri ng them i $n$ a fyke net set downstreamfromthe screen. We will determine if vel ocity patterns adhere to desi gn criteria by measuring approach and sweep vel ociti es in front of the drum and travel ing screens and at the entrances to the bypass channel and the fish return during vari ous phases of operation.

J uveni l e fi sh to be used in the eval uati ons will be hel $d$ at hatchery or accl i mati on facilities and haul ed to study si tes pri or to the tests for freeze brandi ng or dyei ng and accli mation. Fal I chi nook fry wi l be dyed. Freezebranded $\mathrm{fi}$ sh will be hel $d$ in separate contai ners approxi natel y 48 hours before rel ease. 
will pattern our surveys after those perforned by previ ous researchers (Abernethy et al. 1989, Abernethy et al. 1990). We wi I take measurenents duri ng I ow normal and hi gh di versi on fl ous to ascertai $n$ adherence to screening facility desi gn criteria.

Obj ecti ves and correspondi ng tasks for 1991-1992 are as fol I ous.

Objective 1 Determine the passage success of sumer steel head, and spring and $f$ al $l$ races of chi nook sal non through the bypass system in the WEID Canal and the east bank fi sh I adder at Three MIe Fal Is Dam

Task 1.1 Esti mate travel ti me, i nj ury and nortal ity of summer steel head associ ated with the drum screens at desi gn fl ow To esti mate travel ti me, i nj ury and nortal ity associ ated with the drum screens, we will rel ease repl i cate groups of heal thy, freeze- branded $f i$ sh upstream of the screens, recapt ure them at the bypass collection facility, and exam ne the fish for descaling and ot her i nj uri es (treat nent). We will al so rel ease repl i cate groups of heal thy, f reeze- branded fi sh di rectly i nto the col l ection facility to al I ow us to eval uate i nj ury caused by the col I ecti on and exami nati on process (control). We will conduct tests during the day and at ni ght and wi II repeat each day and ni ght test on three different dates at design fl ow Each treat ment and control, day and ni ght rel ease will consi st of three, 100 -fi sh repl i cate groups. We will exami ne a $30 \%$ subsample from each repl i cate group for condi $t i$ on pri or to rel ease to ascertai $n$ pre-rel ease condition. These subsample fi sh will not be returned to thei $r$ groups. We will determine travel ti ne from the rel ease l ocati on upstream of the screens to the collection facility by esti mating the ti ne to recapt ure $50 \%$ (medi an travel ti ne) and $95 \%$ of the rel eased test fish.

We will use the nethod of Neitzel et al. (1985) to determine fish condition. The condi ti on of recapt ured fi sh will be categori zed as heal thy, parti al I y descal ed, descal ed (or dead), and i nj ured (Hosey \& Associ ates 1988). We wi II use anal ysi s of vari ance (ANOVA) to test the hypothesi $s$ that the rel ative condi ti on of control and treat nent fish in the various tests are equal in al I rel eases. Sources of vari ati on tested i $n$ the ANOVA wi I be 1) treat nent versus control, and 2) ti ne of day (day or ni ght). We will transf orm the data as appropriate to meet the assumpti ons of ANOVA For purposes of anal ysi s, we wi I cal cul ate pre-test condi ti on (from subsampl es) and post-test condi ti on (from control or treat ment fish) of fi sh observed as percent ages of recapt ured i nj ured fi sh ( the sum of partly descal ed, descal ed, and other inj ured fish). We will then cal cul ate net inj ury rate as the difference between pre-test and post-test condition. We 
wi I compute a $95 \%$ conf $i$ dence i nterval about the di fference in the net i nj ury rate between correspondi ng treat ment and control groups.

Rati onal e: We were not able to sati sfact ori I y compl ete the screen i nj ury test for summer st eel head i n 1991 because of acci dental I oss of test and control fish.

Products: We will compute mean and $95 \%$ conf $i$ dence interval s for the total proporti on of summer steel head, i nj ured, descal ed or ki Il ed during passage past the screens. We will use anal ysi s of vari ance to test for si gni fi cant difference i $n$ i nj ury rates bet ween the respective treatment and control groups. We will compute travel ti ne for $50 \%$ and $\mathbf{9 5 \%}$ of the recapt ured test $\mathrm{fi}$ sh.

Schedul e: Test preparati on wi l be compl et ed during wi nter 1991-1992. Fi sh will be procured, branded and rel eased during Apri I 1992. Data anal ysi s and a report of resul ts will be compl eted by Septenber 30, 1992 ( Table 1)

Task 1.2 Esti nate travel ti me, i nj ury and nortal ity of fal I chi nook subyearlings associ ated with the bypass pi pe and bypass outfal I at $5 \mathrm{cfs}$ and 25 cfs outfall fl ow To esti mate i nj ury and mortal ity rates associ ated wi th the bypass pi pe and bypass outfall, ue will rel ease repl i cate groups of heal thy, freeze-branded $f i$ sh at the entrance of the bypass pi pe, recapt ure them at the bypass outfall to the river, and examine the fish for descal ing and ot her i nj uri es (treat nent). A fl oati ing net pen placed di rectly beneath the outfal I will be used to recapt ure treat ment fish. We will al so rel ease repl i cate groups of heal thy, f reeze-branded fi sh di rectly into the fl oating net pen to al l ow us to eval uate $i$ nj ury caused by the col l ecti on and handl $i$ ng process (control). We will repeat each test on three di fferent dates and at fl ous of 5 cfs and 25 cfs. Each treat ment and control, 5 cfs and 25 cf s rel ease will consi st of three, 100-fi sh groups. We will exami ne a $30 \%$ subsampl e from each treat nent and control repl i cate subgroup for condi ti on pri or to rel ease to ascertai $n$ pre-rel ease condition. These subsample fi sh wi I not be returned to thei $r$ groups. We wi I determine if fish novement from the bypass downuel I to the bypass outfal I is i mpai red by computing the percentage of $\mathrm{fish}$ recapt ured after a one-hour interval for 5 cf s and 25 cf s bypass fl ow 
We wi I exami ne fi sh for condi ti on and anal yze the data the same as di scussed i n Task 1.1

Rati onal e: We conducted the bypass pi pe and bypass outfal I i nj ury test in 1991 wi th sub-par fal I chi nook subyearlings due to a protracted hol di ng period caused by fl oodi ng and hi gh fl ous.

Products: he will compute mean and $95 \%$ conf $i$ dence interval s for the total proportion of fal I chi nook subyearlings i nj ured, descal ed or ki l l ed duri ng passage fromthe entrance to the bypass pi pe to the bypass outfall at the VEI D facility. We will use anal ysi s of vari ance to test for si gni fi cant di fference in i nj ury rates bet ween the respecti ve treat ment and control groups. We will compute the percentage of test $f i$ sh recapt ured after a one hour interval at operating condi ti ons of $5 \mathrm{cfs}$ and $25 \mathrm{cfs}$ bypass fl ow to determi ne if fish novenent through the I ouer bypass system i s i mpai red.

Schedul e: Test preparati on wi I be compl et ed during wi nter 1991-1992. Fi sh wi I be procured, branded and rel eased during May 1992. Data anal ysi s and a report of resul ts wi I be compl et ed by Sept enber 30, 1992.

Task 1. 3 Esti mate di versi on rate, travel ti me, i nj ury, and nortal ity of sumer steel head and spring and fall races of chi nook sal mon associ ated wi th operati ng the canal headgates at I ess than ful I headgate openi ng: To esti mate $i$ nj ury and nortal ity associ ated wi th passage through a reduced headgate openi ng, we will rel ease subgr oups of heal thy, freeze- branded $f i$ sh upstream of the three headgates, recapt ure them at the col I ecti on faci I ity, and exam ne them for descal ing or other i nj ury (treatment). We will set the headgate openi ngs at appr oxi matel y $1 \mathrm{ft}$. (I/3 of normal oper ati on openi ng). We will fol l ow the same procedures out I i ned i n Task 1.1 to compl ete the test for each speci es or race of fish. Travel ti me will be esti mated from the rel ease l ocati on upstream of the headgates to the col l ecti on facility, as i n Task 1.1 and 1.2. We wi I statistical ly compare nean travel ti me with travel ti me esti mated i n Task 1.1 for sumer st eel head. Di versi on rate wi I be esti mated from the cumul ative percentage of rel eased fi sh entering the canal and arriving at the col lection facility over ti me. We will examine fish for condition and anal yze the data as di scussed in Task 1.1.

Rati onal e: We observed vel oci ty i ncreases caused by 
reduced openi ng si ze of the headgates. Submergence of a reduced ent rance openi ng may subj ect fi sh to nonf avorable hydraul ics and encounters with debris piles.

Products: We will compute mean and $95 \%$ conf $i$ dence interval s for the proporti on of sumer steel head, spring chi nook and fal I chi nook subyearl i ngs i nj ured, descal ed or ki l l ed duri ng di versi on through reduced headgate openi ngs i nto the VEI D canal. We will use anal ysi s of vari ance to test for si gni ficant di fference i $n$ i nj ury rates bet ween treat ment and control groups. We will compute travel ti me for $50 \%$ and $95 \%$ of the recapt ure test fish to determine if fijsh di versi on is i mpeded by a reducti on in the headgate opening.

Schedul e: Fi sh will be procured, branded and rel eased during April and May 1992. Data anal ysi s and a report of resul ts will be compl eted by Septenber 30, 1992.

Task 1. 4 Document passage ( l eakage) and i mpi ngenent of $f$ al I chi nook fry and subyearl ings associ ated with the travel ing screen when operati ng pump-back bay punps i n tandem or i ndi vi dual $I y$ and varyi ng gate openi ngs of the ri ver return drai $n$ pi pe: To document the ext ent of passage around and over the travel ing screen in the VEI D canal of snal I er-si zed fish, we will instal I a fyke net at the terminus of the 21-i nch di aneter ri ver return drai $n$ pi pe. The drai $n$ pi pe will be i $n$ operation during the sampling mode when the travel ing screen is functi oni ng but the pumpback pumps are not. A I fi sh that pass through or over the operating travel ing screen wi I eventual I y be di verted through the drai $n$ pi pe and recapt ured in the fyke net. We will count fish i mpi nged on the travel ing screen or fi sh that have I eaked around the screen and into the fyke net at varyi ng openi ngs of the ri ver return drai $n$ pi pe. When ri ver fl ow drops and bypass fl ow needs to be di verted back to the canal, the drai $n$ pi pe will be closed and the pumpback pumps will be put into operation. We will count fi sh i mpinged on the travel ing screen when operati ng the pumpback pumps in tandem or i ndi vi dual I y. Leakage can not be detected due to the i nabil ity to recapt ure fish during pump operation. To make counts and observations, we will rel ease groups of fal l chi nook fry upstream of the travel ing screen. We will al so observe I eakage and i mpi ngenent duri ng tests usi ng fal I chi nook subyearlings and the during the subyearling outmigration.

Rati onal e: I n 1991, we observed sone i mpi ngenent of fal I chi nook fry and subyearlings on the travel ing screen i $n$ 
the VEI D Canal during pumpback pump operati ons and at varyi ng l evel s of ri ver return drai $n$ pi pe gate openi ngs. We col lected a fall chi nook subyearling in a fyke net placed at the terminus of the river return drai $n$ pi pe.

Products: We will document the presence or absence of I eakage or i mpi ngenent of fal I chi nook fry and subyearlings around or on the travel ing screen associ ated with the operation of the pumpback pumps in varyi ng conbi nations and with a full and throttled ri ver return drai $n$ pi pe gate opening.

Schedul e: Fabri cati on of a new ri ver return drai $\mathbf{n}$ pi pe fyke net will be compl eted during the fall of 1991. We wi I observe I eakage and i mpi ngenent of $f$ al I chi nook fry in early Apri I and of fal I chi nook subyearlings in Myy. A report of our observations will be compl eted by Sept enber 30, 1992.

Task 1.5 Esti mate i nj ury of spring chi nook sal mon at varyi ng degrees of $t$ urbul ence in the bypass downuel I caused by changes in fl ow and water I evel: To esti nate i nj ury of spring chi nook in the bypass downuell, we will rel ease fi sh at the wei $r$ crest in the bypass channel and recapt ure them at the bypass outfall in the fl oating net pen. We will vary the bypass channel fl ow and water hei ght in the downuel I to test i nj ury l evel s agai nst varyi ng turbul ence condi ti ons in the downuel I. We wi I al so rel ease fi sh di rectly in the 24-i nch bypass pi pe to serve as our control. We wi I performsi milar test procedures, exami ne fi sh and anal yze data as di scussed i n Task 1.1 .

Rati onal e: General observati ons of poor condi $t i$ on of spring chi nook in the bypass pi pe and outfal I test conducted in 1991 indi cate that turbul ence in the bypass downuel I may be causi ng i nj ury.

Products: We will compute mean and $95 \%$ conf $i$ dence interval s for the proporti on of spring chi nook that are inj ured or descal ed during passage into the downuel I at varyi ng degrees of turbul ence caused by changes i $n$ fl ow and water level. We will determi ne if i nj ury rates of treat ment $f i$ sh are si gnifi cantl y di fferent from control fish usi ng ANOVA

Schedul e: See Table 1 . 
Task 1.6 Document passage, i nj ury and mortal ity of Sumer st eel head, and spring and fal I races of chi nook sal non associ at ed with the east bank fi sh I adder during the j uveni l e out migration: To document the extent of passage of out migrating $j$ uveni l e sal noni ds through the east bank fi sh I adder and possi ble inj ury and nortal ity associ ated with this passage, we will enumerate snol ts passi ng by the fi shury vi ewing wi ndow from vi deo tapes of adul $t$ passage recorded by CTU $R$. W will al so vi sual I y observe novenent of $j$ uveni I e fi sh through the vari ous components of the I adder, i ncl udi ng the attracti on water wei $r$ and the entrance pool and other di ff users. We wi I coll ect and brand good-condi ti on fi sh at the bypass facility, rel ease them in the upper portions of the I adder, and col I ect them at the base of the I adder to esti mate i nj ury i ncurred as fi sh pass through the I adder structure. Fi sh conditi on will be ascertai ned as described i n previ ous tasks. We will rel ease $f i$ sh i n our capt ure faciliti es to eval uate i nj ury caused by collection and handl i ng ( control).

Rati onal e: We observed j uveni l e passage through the east bank I adder i n 1990 and recorded passage counts from vi deo tapes of adul t passage in the spring of 1990. Rel at i ve passage rates through the east bank I adder appeared to be si milar to passage through the west bank j uveni l e bypass facility during the same ti me peri od, i ndi cati ng that smol ts use the ladder as a neans to bypass the dam even when the bypass i s i $n$ operation.

Products: We wi I I document numbers of $j$ uveni I e sumer steel head, and spring and fal I races of chi nook sal mon passi ng through the east bank adult $\mathrm{f} i \mathrm{sh}$ I adder at Three M I e Fal Is Damin 1991 and 1992. We wi I esti mate i nj ury l evel s of juveni l e sal moni ds passi ng through the I adder to prel i mari ly ascertai $n$ if I adder passage occurs in an ef fecti ve and noni nj urous manner.

Schedul e: We will conduct vi sual observati ons and test rel eases at the eastbank I adder during the springsummer out mi grati on from mid-Apri l to mid-J une 1992. We will read 1991 adult passage vi deo tapes in the fal I and wi nter of 1991-1992.

Obj ecti ve 2 Ensure effi ci ent operation of the $j$ uveni le sal noni $d$ bypass and col l ecti on system i $n$ the canal at Westl and Di versi on Dam and desi gn, fabri cate, and test al I necessary capt ure facil i ti es in preparation for passage eval uati on activities in 1993. 
Tasks 2. 1 Operate the bypass and hol di ng pond facilities at West I and Dam We will operate the bypass and hol di ng pond facilities in concert wi th i rrigation di strict and trap and haul personnel to fami i arize oursel ves with the overall operation and ensure that the facilities operate as desi gned. We will test operate al I systens and structures, i ncl udi ng gat es, pumps, fi sh separat or, bypass i nf I ow and outf I ow the $\mathrm{j}$ uveni l e hol di ng pond and associ ated sampl i ng system and the drum and travel ing screens. A I aspects of the day to day operation of the facility will be nonitored. We will test operate the bypass faci I i ty when j uveni I e sal moni ds are mi grati ng past West I and Dam We wi I I test operate the $j$ uveni l e col l ecti on and hol di ng system duri ng trap and haul operati ons when river fl ow is l ow

Rati onal e: We were not able to gai n a thorough understandi ng of faci I ity operati on through extensi ve hands- on experi ence i $\mathbf{n} 1991$ because of I i mited manpower resources and ti ne constrai nts. Ability to conduct a successf ul eval uati on is cont i ngent on operati onal experti se due to the compl exi ty and uni queness of the West I and Canal system and $j$ uveni I e facility.

Products: Thor ough know edge of faci I ity operati on at West I and Dam and ensurance of an ef $f i c i$ ent and properl y functi oni ng system that wi I be ready to eval uat e after October 1, 1992.

Schedul e: We wi I familiarize oursel ves with the system through hands- on operati on duri ng the 1992 spring, sumer, and fal I j uveni l e out mi gration. A report of acti vi ti es and fi ndi ngs wi II be compl eted by Sept enber 30, 1991.

Task 2. 2 Desi gn, fabri cate and test capt ure faci lities necessary for conducti ng eval uati on acti vi ti es i n 1993 at Wéstl and Dam We wi I I desi gn and fabri cate collection facilities to be used at the bypass out l et, downst ream of the drum and travel ing screens, and i $n$ the bypass channel in the West I and Canal. These capt ure faciliti es will be used i n vari ous i nj ury and l eakage tests i n 1993. Traps wi I be si milar in desi gn to those used in eval uati ons at Three Mle Fal Is Dam

We will test operate the collection facilities duri ng the migration peri od of $j$ uveni l e sal noni ds. 
We will rel ease and recapt ure marked fi sh to eval uate the effici ency of the traps in capt uring the maj ority of $f i s h$, and to ensure that the trapping process does not resul $t$ i n excess inj ury or nortal ity. A modified fyke net wi th fl oating I i ve box has been fabri cated and tested and will be used for capt uring test fi sh i $n$ the j uveni l e hol di ng pond. We will col I ect sampl es of ri ver run fi sh in these traps to determine if i nj ury or mortal ity l evel s are obvi ously hi gh.

Rati onal e: We were not abl e to sat i sfact orily compl ete bypass channel and bypass outl et capt ure faci l ity desi gn and fabrication due to struct ural compl exiti es of the bypass system and "flood-caused" al teration of the ri ver channel at the outl et.

Products: Abi lity to efficient l y and effecti vel y col l ect $f i$ sh at def $i$ ned I ocations in the canal and bypass system at Westl and Dam Abi I ity to conduct tests to determine passage success of $\mathbf{j}$ uveni I e sal noni ds through the bypass system in the Uestl and Canal after October 1, 1992. Docunent ati on of hi gh i nj ury or nortality rates of river run fish.

Schedul e: Traps wi I l be desi gned and fabri cated during spring 1992. Traps will be test operated during sumer and fall 1992. A report of results wi I l be compl et ed by Sept enber 30, 1992.

Objective 3 Determine if vel ocities at defined locations in the bypass systens at Three MIe Fal Is and Westl and dans neet design criteria.

Task 3. 1 Measure approach vel ocity in the bypass channel and approach and sueep vel oci ti es through the travel ing screen at Three Mle Falls Dam We will use an el ectronagnetic water current meter and record vel ociti es ( $f$ eet per second) at $0.2,0.5$, and 0.8 percent of uater depth. Measurenents will be taken at centerl $i$ ne and at the upstream and downstream edges of the traveling screen, and at the entrance to the bypass channel. The probe will be positioned paral lel to the screen poi nti ng upstream for recordi ng sweepi ng vel oci ti es and poi nted perpendi cul arl y away from the screen for recording approach vel ocities. We will measure vel ocities at the travel ing screen and at the entrance to the bypass channel during operation of the pumpback pump in tandem or i ndi vi dual $\mathrm{l} y$ and at varying gate openi ngs of the river return drain pi pe. We will 
al so measure vel ociti es in the bypass channel during a 25-cf s fl ow Headuork el evati on, canal fI ow and operating conditions, water depth, and ti me to measure will be noted.

Products: We will determine if vel ocity patterns meet design criteria at the bypass channel entrance and at def $i$ ned I ocations in front of the travel ing screen during varying operati ons of pumpback pumps and ri ver return drai $n$ pi pe gate i $n$ the VEI D Canal at Three MIe Fal Is Dam

Schedul e: We will measure vel ocity patterns at defi ned I ocati ons in the VEI D Canal during Apri I and Nay 1992.

Task 3. 2 Measure approach and sweep vel ocity at the drum screens, travel ing screens, and entrance to the bypass channel at Westl and Dam we will foll ow the same procedure as descri bed i n Task 3.1. We will take measur enents during I ow medi um and hi gh canal fl ous to determine if vel ocity patterns meet criteria at al I operati ons. Drum screen vel ocity neasurements wi I be taken cl ose to the screens and at the centerli ne peri meter of the screens. Headworks el evati on, canal fl ow and operating condi ti ons, drum screen submerged dept $h$, and travel ing screen operati ons will be recorded.

Products: We will determine if vel ocity patterns neet desi gn criteria at the drum screens, travel ing screens and at the entrance to the bypass channel at Westl and Dam at I ow nedi um and hi gh canal f I ous.

Schedul e: We will measure vel ocity patterns at def i ned I ocati ons in the Westl and Canal from Apri I to J une 1992. 


\section{REFERENCES}

Abernethy, C. S., D. A Neitzel, and E. W Lusty. 1989. Vel ocity neasurements at si $x$ fish screening facilities in the Yaki ma Ri ver Basi n, Whshi ngt on, sumer 1988. Prepared by the Pacific Northwest Laborat ory, Ri chl and, Wishi ngt on, for the Di vi si on of Fi sh and Wil dl ife, Bonnevi I l e Power Admi ni stration, Portl and, Oregon.

Abernethy, C. S., D. A Neitzel, and E. W Lusty. 1990. Vel ocity measurenents at three fish screening facilities in the Yaki ma Basi n, Whshi ngt on, summer 1989. Prepared by the Paci fi c Northwest Laborat ory, Ri chl and, Wishi ngt on, for the Di vi si on of Fi sh and Vil dl ife, Bonnevi I l e Power Admi ni stration, Portl and, Oregon.

Hosey and Associ ates. 1988. Eval uat $i$ on of ecti veness of $f i$ sh protection facilities. Chandl er facility eval uation. Report by Hosey \& Associ ates Engi neering Company for the U.S. Bureau of Recl anati on.

Neitzel, D. A , C. S. Abernethy, E. W Lusty, and L. A Prohamer. 1985. A $\mathbf{f i}$ sheri es eval uati on of the Sunnysi de Canal $\mathbf{f i}$ sh screening facility, spring 1985. Prepared by the Pacific Nort hwest Laborat ory, Ri chl and, Whishi ngt on for the Di vi si on of Fi sh and Vil dl i fe, Bonnevi I I e Power Admi ni strati on, Port l and, Oregon. 
Table 1. Act i vity schedul e sumary for eval uating j uveni $\mid \mathbf{e}$ sał moni d passage facil ities at Three MIe Fal Is and Westl and dans, October 1991 through Septenber 1992.

\section{Month}

Activity Oct Nov Dec Jan Feb Mar Apr May Jun Jul Aug Sep

\section{Gear}

Preparati on

St udy Desi gn -

Task 1.1

Task 1.2

Task 1.3

Task 1.4

Task 1.5

Task 1. 6

Task 2. 1

Task 2.2

Task 3.1

Task 3.2

Data Anal ysi s

Report Witing

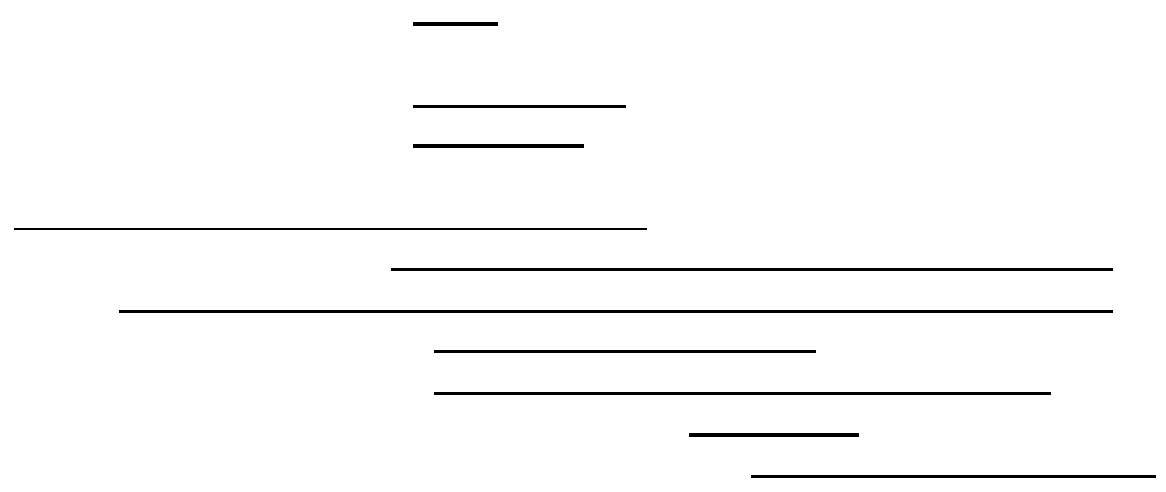

